BIBLIOTHECA

IBERO-AMERICAN/A

VERVUIERT

neinhard I iehr (ed.)

Empresas y modernización en México desde las reformas borbónicas hasta cl Porfiriato

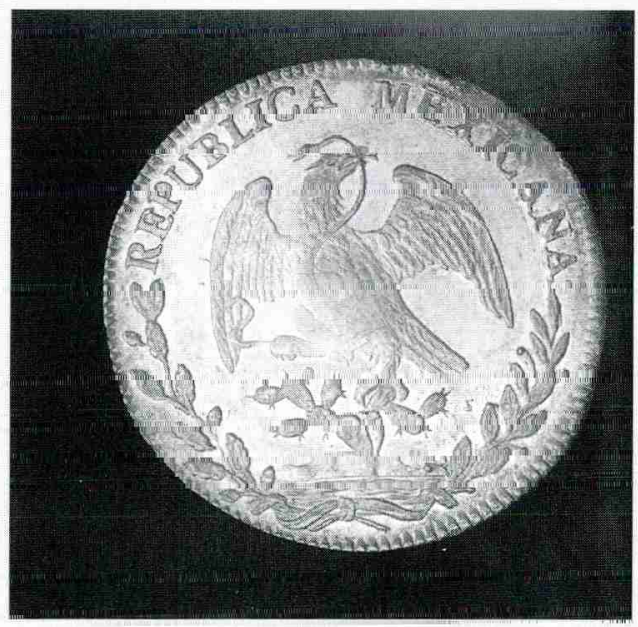



Reinhard Liehr (ed.)

Empresas y modernización en México

desde las reformas borbónicas

hasta el Porfiriato

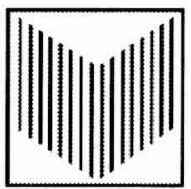


B I B L I O T H E C A I B E R O-A M E R I C A N A

Publicaciones del Instituto Ibero-Americano Fundación Patrimonio Cultural Prusiano Vol. 108 
B I B L I O T HEC A I B E R O-A M ER I C A N A

Reinhard Liehr

(ed.)

\section{Empresas y modernización \\ en México \\ desde las reformas borbónicas \\ hasta el Porfiriato}

Iberoamericana $\cdot$ Vervuert 
Bibliographic information published by Die Deutsche Bibliothek

Die Deutsche Bibliothek lists this publication in the Deutsche

Nationalbibliografie; detailed bibliographic data are available on the

internet at http://dnb.ddb.de

(C) Iberoamericana 2006

Amor de Dios, 1, E-28014 Madrid

Tel. +34914293522

Fax +34914295397

(C) Vervuert Verlag 2006

Wielandstr. 40, D-60318 Frankfurt am Main

Tel. +49695974617

Fax +49695978743

info@iberoamericanalibros.com

www.ibero-americana.net

ISSN 0067-8015

ISBN 84-8489-259-X

ISBN 3-86527-270-3

Depósito legal: B-20.724-2006

Reservados todos los derechos

Diseño de la cubierta: Michael Ackermann

Foto de la cubierta: Anverso de un peso de plata de ocho reales (1824) con los símbolos nacionales

Este libro está impreso integramente en papel ecológico blanqueado sin cloro Composición: Anneliese Seibt, Instituto Ibero-Americano, Berlín Impreso en España 


\title{
ÍNDICE
}

\author{
Reinhard Liehr
}

Introducción

Alejandro Tortolero Villaseñor

Los caminos de agua en la producción y el comercio en

el sureste de la cuenca de México en la segunda mitad del

siglo XVIII

Rosa María Meyer Cosio

El difícil equilibrio. Tropiezos de una empresa británica

con el Gobierno mexicano

Carlos Riojas

Consideraciones metodológicas para el estudio del proceso

de industrialización en el occidente de México durante el

siglo XIX

Lucía Martínez Moctezuma

Íñigo Noriega Laso: un empresario agrícola en México

1868-1913

Abreviaturas

Autoras y autores 



\section{Reinhard Liehr}

\section{Introducción}

El presente volumen reúne cuatro capítulos que originalmente fueron escritos para la revista Iberoamericana (Frankfurt/Main, <http://www. iberoamericana.de $>$ ), sin embargo, por su tamaño excesivo no pudieron ser publicados en ella. Los autores examinan la historia económica, sobre todo la historia de las empresas y de los empresarios, así como sus intentos de modernizar la economía y la sociedad de México desde las reformas borbónicas a fines de la época colonial hasta el Porfiriato.

El tipo más frecuente de empresas, tanto en México, el resto de América Latina y el Asia Oriental, como en Europa y los Estados Unidos durante los siglos XVIII y XIX, incluida la primera industrialización, era la empresa familiar. La empresa de propiedad y control familiar predominaba en los sectores de las industrias fabriles de igual manera que en el comercio, la banca y otros servicios. Continuó siendo exitosa en estas regiones, tanto periféricas como centrales, hasta la tercera revolución industrial, hallándosela al lado de la gran corporación industrial, importante por su capital y tecnología, administrada por jerarquías de managers profesionales, como la describe Chandler para el siglo XX (Chandler et al. 1997: 50-56, 80-101; Chandler 1995: 1-14). En el México periférico durante los siglos XVIII y XIX la empresa familiar ayudaba a compensar la debilidad de las instituciones estatales para enfrentar muchas veces la inseguridad y la desinformación, así como también era determinante el sector financiero que todavía estaba poco desarrollado y no ofrecía créditos económicos suficientes. La empresa familiar respondía exitosamente a estos riesgos, gracias a sus redes de comunicación basadas en la familia, el parentesco y el propio grupo étnico, cuyos miembros reconocían un código moral que generaba la confianza y proporcionaba la información necesarias para reducir los costos de transacción en los negocios (Colli 2003; Dávila/Miller 1999: 13-16).

Hasta la primera e incluso la segunda revolución industrial, la familia empresarial de la clase media y también de la alta de Europa y 
América Latina abarcaba como grupo básico de solidaridad la familia extensa trigeneracional. Comprendía al empresario mismo, a su esposa, a sus hijos y a todos los miembros de la familia de los padres no sólo de él, sino también de ella (Adler Lomnitz/Pérez Lizaur 1987: 125-127). Hubo que conciliar los intereses de la familia con los de la empresa, además incluso pensar en los compadres, siempre que se arreglaba un matrimonio, un bautizo o un entierro, se organizaba la educación de los hijos y se guardaban los rituales de la familia y el código moral sancionado por la Iglesia católica y las tradiciones familiares. Hasta hoy, la familia empresarial mexicana y latinoamericana no corresponde al modelo de la familia nuclear de dos generaciones.

Desde la época colonial, en México las empresas familiares se movían dentro de las instituciones estatales con los derechos de propiedad y el derecho mercantil heredados de tradiciones romanas, hispanas y mediterráneas. Las instituciones del Estado, de la Iglesia católica y de la familia formaban la esfera de protección tradicional, con la cual el empresario y los miembros de su familia contestaban a las presiones de los cambios políticos y las modernizaciones, sobre todo durante las guerras de la Independencia, la Reforma y la intervención francesa, así como durante el Porfiriato y la Revolución.

En el derecho mercantil de las Ordenanzas de Bilbao y los códigos de comercio posteriores, tanto de España como de México y los otros países hispanoamericanos, la empresa familiar podía ser del tipo de la de un comerciante con una responsabilidad ilimitada, es decir, la empresa de un sólo propietario y gerente, quien por lo general también la fundaba. El segundo tipo más desarrollado de empresa familiar era la de una compañía o sociedad, en la cual dos o más compañeros o socios juntaban su capital o su trabajo, dividiendo de esta manera los riesgos de sus negocios. En el siglo XIX la sociedad tomó a veces la forma de una sociedad en comandita, en la cual el gerente tenía una responsabilidad mayor. Es desde finales del siglo XIX que la empresa familiar pudo ser también de un tercer tipo, es decir, el de la sociedad anónima (Rodríguez de San Miguel 1991, II: 353-367, 600-608; Código de Comercio 1889).

El primer capítulo, de Alejandro Tortolero Villaseñor, se dedica a esclarecer el poco estudiado tema de los caminos de agua en México, concentrándose en los de la cuenca de México durante la segunda mitad del siglo XVIII. Tortolero no está de acuerdo con la historiogra- 
fía del desarrollo del transporte que destaca el papel dominante de los caminos de tierra firme y de la arriería en la época colonial en México, así como de los ferrocarriles durante la industrialización. Hasta ahora muy pocos autores han estudiado el transporte de las rutas lacustres y los canales en el altiplano del país. Como punto de partida, Tortolero analiza el abastecimiento de la ciudad de México, sobre todo de maíz. Este producto básico de consumo y de energía provenía en su mayor parte de las grandes haciendas de la provincia de Chalco, desde las cuales era transportado en canoas por tortuosos canales navegables de unos 72 kilómetros de largo hasta el centro de la ciudad de México. Los terratenientes de las grandes haciendas de la provincia de Chalco, denominados como "el nervio de la república", formaron un grupo empresarial fuerte, con residencia en la capital novohispana. Estos grandes terratenientes, como don Manuel de Rivas Cacho, estaban ligados, también por parentesco, a comerciantes y políticos y empleados de la administración colonial. La propiedad de la tierra y el parentesco unían a esta élite empresarial como grupo de presión. El transporte económico por los canales navegables y los altos precios de maíz en el abastecimiento de la capital de México favorecían la imposición de los intereses y el acrecentamiento de los capitales de los grandes empresarios agrarios de Chalco. Estas ventajas en la comercialización de sus productos no estuvieron al alcance de otros grupos de hacendados, como los de Toluca y de Puebla. Además, Tortolero subraya que las grandes haciendas maiceras de la provincia de Chalco eran sumamente fértiles, así que no sorprende que en 1759 tuvieran una producción mayor que en 1893, en pleno Porfiriato.

Rosa María Meyer Cosío estudia en el segundo capítulo la casa comercial británica más importante de la ciudad de México durante la primera mitad del siglo XIX: la de Manning y Mackintosh (18241852). Éste es un caso excepcional que no se puede generalizar. Hay que recordar que Gran Bretaña había salido indiscutiblemente de las Guerras Napoleónicas como el nuevo centro económico y político del sistema mundial y que México había sido entre 1781-1810 el país productor de plata más importante del mundo. A finales de los años veinte, Ewen $\mathrm{C}$. Mackintosh ingresó como dependiente a la compañía mercantil británica de Manning y Marshall, para ascender, después de algún tiempo, a socio de la nueva firma de Manning y Mackintosh. El regreso de Guillermo Marshall a Inglaterra y la muerte inesperada de 
Roberto Manning dejaron a Mackintosh, a partir de 1834, como único gerente responsable de la empresa. Con su establecimiento principal en la capital y una sucursal en Veracruz, la casa comenzó a trabajar desde 1824 como importadora al por mayor de productos manufacturados. Además, compraba y comercializaba artículos de tabaco dentro de México. Como comisionista de la banca mercantil Barclays, Herring and Richardson y después de Baring Brothers and Co. transfería también a través de letras de cambio a Londres las sumas de dinero para cubrir los intereses de los bonos de los primeros dos empréstitos ingleses. Al mismo tiempo, la casa actuaba frente al Gobierno central mexicano como apoderada de los tenedores de bonos de los empréstitos ingleses. Trabajaba como comisionista de las compañías mineras británicas Anglo-Mexican Mining Company Limited y United Mexican Mining Company Limited. Como banco mercantil, negociaba en letras de cambio y abría líneas de crédito a otros comerciantes. Arrendaba del Gobierno central la casa de moneda de Guanajuato y pronto otras más, incluso la de México, modernizándolas y llegando a controlar más del $80 \%$ de la plata y del oro acuñados. Arrendaba también, junto con otros inversionistas, el monopolio del tabaco con el propósito de modernizar sus establecimientos. A partir de 1834, Mackintosh, casado con una mexicana y aliado a la élite económica de la capital, entró a los negocios riesgosos de los llamados "agiotistas", que contrataban préstamos en gran escala con el Gobierno central. La casa de Manning y Mackintosh intervenía en varias negociaciones de la deuda interna y externa. Desde1839, la influencia de Mackintosh creció aún más con su nombramiento como cónsul de la Gran Bretaña en la ciudad de México. Entre 1850 y 1852 la casa de Manning y Mackintosh entró en quiebra por los contratos riesgosos de préstamos al Gobierno central mexicano y en 1861 Mackintosh murió, dejando a sus herederos sus pleitos pendientes por las sumas prestadas.

El tercer capítulo, de Carlos Riojas, analiza el modelo protoindustrial en sus componentes esenciales así como su importancia y sus límites en el proceso y los espacios de la industrialización en México, sobre todo en el estado de Jalisco durante el siglo XIX. Compara el modelo protoindustrial con otros conceptos teóricos sobre la industrialización interesados en los países en vías de desarrollo. La protoindustrialización es la "industrialización antes de la industrialización" (Kriedte et al. 1986), es decir, un fabricante-mercader hacía uso del 
excedente de mano de obra en el campo, debido al crecimiento demográfico, para que pequeños campesinos-artesanos produjeran artículos manufacturados en sus casas, sobre todo textiles, con lo que complementaban el ingreso familiar. Los campesinos-artesanos eran financiados por el empresario, recibiendo las materias primas o dinero en efectivo para la compra de ellas o algunos medios de producción, para entregar más tarde los productos manufacturados para su comercialización. En este Verlagssystem los pequeños productores trabajaban por encargo del empresario y perdían mucha de su independencia. Era el Verleger quien, como empresario, imponía las normas cuantitativas y cualitativas y una mayor disciplina de trabajo, aspectos que conllevaban una mayor racionalización de la producción. Para el sistema protoindustrial el fabricante-mercader o Verleger era clave, pues, como empresario mercantil y fabril organizaba la producción doméstica de productos manufacturados para comercializarlos y los mandaba a mercados suprarregionales o, incluso, supranacionales. Si la producción protoindustrial llegaba a montos significativos para los mercados supranacionales, era capaz de transformar una regiôn entera. Sin embargo, la expansión regional en el campo tenía sus límites por los incrementos en los costos de transacción. Cuando Riojas intenta aplicar el modelo protoindustrial a todo México y a Jalisco en especial es porque lo encuentra ventajoso, pues en comparación al modelo clásico ofrece varias posibilidades de industrialización. Sin embargo, Riojas observa que la investigación aplica este concepto para la época colonial, pero no de manera acertada. Destaca que en los escasos estudios para el siglo XIX, hasta el presente no se puede hablar de sistemas o regiones de protoindustrialización en México, aunque sin duda se dieron varios elementos en esa dirección en la industrialización del país.

Lucía Martínez Moctezuma nos presenta en el cuarto capítulo las diferentes empresas y las estrategias del inmigrante asturiano Íñigo Noriega Laso. Éste no es un caso especial, sino representativo de los empresarios que inmigraron del norte de España para "hacer las Américas" e impulsaron el crecimiento económico del país durante el Porfiriato. Llegó pobre a México en un proceso de migración en cadena, para comenzar en compañía de su hermano en un establecimiento de comercio y dedicarse más tarde también a la explotación de tabaco y a la industria textil. Después de haber acumulado un capital considera- 
ble, comenzó una segunda carrera empresarial, la de un empresario moderno de grandes empresas agrícolas altamente desarrolladas. Las fundó junto con un grupo de amigos como sociedades anónimas, para modernizarlas y aumentar los capitales invertidos, aprovechando las ventajas del creciente sector financiero y del mercado de capitales en la ciudad de México durante el Porfiriato. Sus empresas agrícolas en el municipio de Chalco eran la Compañía Agrícola de Xico y Anexas, S.A. y la Compañía Agrícola y Colonizadora Mexicana, S.A., con mercados en el abastecimiento de la capital. Era propietario de otras grandes empresas en Tamaulipas y en Chihuahua. La modernización técnica, personal y administrativa de las empresas incrementó tanto su valor que en 1913 -Íñigo Noriega murió en 1920- su fortuna alcanzó unos 40 millones de pesos. Sus estrategias empresariales se vincularon extraordinariamente bien con sus dos matrimonios, el primero con la hija de un comerciante y el segundo con la hija de un empresario de la élite económica de la capital.

Tanto Alejandro Tortolero con los grandes hacendados de Chalco, como Rosa María Meyer con la casa comercial de Manning y Mackintosh y Lucía Martínez con el grupo de empresas de Íñigo Noriega hacen hincapié en la importancia de las redes de comunicación como exitosas estrategias de los empresarios y sus compañías. En todos los estudios, muchas veces por falta de fuentes más específicas, no está claramente delimitada la función de la empresa o del grupo de empresas, así como la influencia de la familia del empresario.

Agradezco la ayuda en esta edición a Isabel Galaor y a Georg Fischer. 


\section{Bibliografía}

Adler Lomnitz, Larissa/Pérez Lizaur, Marisol (1987): A Mexican Elite Family, 18201980. Kinship, Class, and Culture. Princeton, N. J.: Princeton University Press.

Código de Comercio (1989): "Código de Comercio". En: Diario Oficial del Gobierno de los Estados-Unidos Mexicanos. México, D.F., 7-13 de octubre de 1889.

Colli, Andrea (2003): The History of Family Business, 1850-2000. Cambridge: Cambridge University Press.

Chandler, Alfred D. (1995): The Visible Hand. The Managerial Revolution in American Business. Cambridge, Mass.: Belknap Press of Harvard University Press (13. ${ }^{\text {a }}$ ed. de la $1 .^{\text {a }}$ de 1977$)$.

Chandler, Alfred D., et al. (eds.) (1997): Big Business and the Wealth of Nations. Cambridge: Cambridge University Press.

Dávila, Carlos/Miller, Rory (eds.) (1999): Business History in Latin America. The Experience of Seven Countries. Liverpool: Liverpool University Press.

Kriedte, Peter, et al. (eds.) (1986): Industrialización antes de la industrialización. Barcelona: Crítica.

Rodríguez de San Miguel, Juan N. (1991): Pandectas hispano-mexicanas. 4. ${ }^{\mathrm{a}}$ ed., facsimilar de la $2{ }^{a}$ corregida de 1852,3 vols., México, D.F.: Universidad Nacional Autónoma de México. 

Alejandro Tortolero Villaseñor

\section{Los caminos de agua en la producción y el comercio en el sureste de la cuenca de México en la segunda mitad del siglo XVIII}

Curioso elemento del paisaje en el valle de México, el camino de agua, la vía navegable, es una presencia que no escapa a la mirada del viajero, del cronista, del paisajista o del poeta. Su existencia le otorga una particularidad al paisaje, que aparece como una correa de transmisión entre lo urbano y lo rural. Si la ciudad de México se asemejara a una enorme máquina devoradora de la energía creada en el mundo rural, los caminos y los canales de agua serían sus mecanismos transmisores. Sin embargo, los historiadores apenas nos hemos ocupado de tan curioso detalle. En general, hemos asumido que en el mundo preindustrial el tráfico interno de mercancías se hacía a través de la arriería (Suárez Argüello 1994; 1997) y los caminos de tierra firme (Ortiz Hernán 1970; García Martínez 1992; 1995), mientras que en el mundo industrial eran los ferrocarriles el medio conductor de mercancías y hombres (Coatsworth 1984; 1990; Kuntz 1995a; 1995b). Entre ambas maneras de transporte, sin embargo, están los canales navegables en la cuenca de México. Un elemento que le otorga dinamismo al movimiento de mercancías en el mundo preindustrial y que sobrevive y se articula con los ferrocarriles en el momento de la industrialización (Martínez/Tortolero 2000: 119). Este artículo explora estos caminos de agua del valle de México, tomándolos como un mirador para aden-

El presente artículo fue redactado gracias a la hospitalidad del profesor R. Liehr, quien me asoció, como profesor invitado, a su seminario sobre Historia de America Latina en la Universidad Libre de Berlín, durante el periodo de mayo a julio del 2000. Agradezco al profesor Liehr y al DAAD el apoyo durante mi estancia de investigación, al Dr. Günter Vollmer su apoyo en la consulta de materiales en la Biblioteca del Instituto Iberoamericano de Berlín, a Alexander Lotze su gentileza en la reproducción de imágenes y a N. Böttcher su hospitalidad. El profesor R. Romano hizo agudos comentarios a una versión previa de este trabajo. Gracias a ellos, el trabajo intelectual en Berlín fue una experiencia amable y estimulante. Mi proyecto de investigación es apoyado por CONACYT (H-43960). 
trarnos en la producción y el comercio de mercancías entre la ciudad de México y su hinterland en la segunda mitad del siglo XVIII.

En efecto, la vieja opinión de Salvador Ortiz, quien señala en 1929 que "el arriero con su atajo de mulas, llevando mercancías de una a otra parte, fue el único sistema de explotación, desde la dominación española, hasta poco después de la introducción de los ferrocarriles", prevalece en los estudios sobre los transportes y el mercado. ${ }^{1}$ John Coatsworth, por ejemplo, menciona que la inexistencia de ríos navegables y la reducida dimensión del tráfico por lagos sólo beneficiaba al comercio local y concluye que, antes del ferrocarril, las recuas de mulas o burros excedían la carga embarcada en carretas en 18 de las 24 rutas del país hacia $1880 .^{2}$

Un problema para avanzar en este campo es el que señala Suárez Argüello, cuando dice que para Europa, Estados Unidos e inclusive partes de Latinoamérica existe una amplia y consistente historiografía sobre el transporte y su desarrollo; en México, no obstante, estos estudios no tienen tradición. ${ }^{3}$ En efecto, este es un tema inédito que sólo ha sido mencionado escasamente en los estudios de historia económica que mencionamos en este artículo y sólo contados trabajos lo hacen un tema de estudio explícito (Sierra 1973; Hassig 1990; Musset 1992). Mientras que Sierra sólo describe las rutas lacustres, los privilegios e invenciones que tratan sobre la explotación de estos canales sin más apoyo que las gacetas y la bibliografía, Hassig y Musset se ocupan más de los aspectos económicos y se apoyan en fuentes de archivo. Hassig, por ejemplo, estudia el comercio, el tributo y el transporte en el valle de México en el siglo XVI, para lo cual se ocupa de la relación entre ciudad e hinterland como un tema clave en donde la población, el potencial agrícola de la tierra, las tasas de consumo y la eficiencia de los transportes son elementos relevantes. Musset, en su excelente estudio sobre "El agua en el valle de México", dedica un capítulo a los

1 Véase Flores Clair (2000) en su reseña al libro de Suárez Argüello (1997).

2 Coatsworth (1984: 28, 67). Para las carretas, véase p. 89. En sus trabajos posteriores el autor reafirma: "Con excepción de algún transporte local en tres grandes lagos situados en las tierras altas y de pequeños tramos de algunos ríos del Golfo que llegaban hasta la base de las montañas, el transporte por agua era desconocido" (Coatsworth 1990: 189).

3 Suárez Argüello (1997: 21). El trabajo de Calvo sobre los transportes y los transportistas en Nueva Galicia en el siglo XVII confirma la idea de Suárez Argüello (Calvo 1997: 13). 
transportes lacustres y la organización del espacio. Allí, señala la importancia decisiva de Chalco como puerto de tráfico comercial que no tiene rival alguno, ya que Texcoco, "desde antes de la llegada de los españoles $[\ldots]$ ya no era un gran puerto [...], la ciudad de Nezahualcóyotl jamás es citada en las crónicas como punto de carga y descarga de la importancia de Chalco". Sin embargo, también señala que evaluar el tráfico de mercancías es difícil ya que, pese a los controles de la administración pública, gran parte de la mercancía escapaba a las estadísticas rudimentarias de la época. ${ }^{4}$ Una propuesta de estudio de este escurridizo tráfico la encontramos en las siguientes páginas.

\section{Los caminos de agua}

La ciudad de México al finalizar el siglo XVIII tenía una población de 112.926 habitantes. ${ }^{5}$ A pesar de no contar con estudios detallados sobre los consumos de sus habitantes, podemos asumir, de acuerdo a nuestras fuentes, que los cereales, maíz y trigo, eran los elementos fundamentales en sus dietas. Si el trigo es importante sobre todo, pero no únicamente, para la población "blanca", en cambio, el maíz lo es para la indígena.

En efecto, las descripciones con que contamos señalan esta importancia, como vemos en la siguiente cita:

Esta semilla solo sirve para manutención de la gente mas miserable y de los indios haciendo de ella atole que es un equivalente del chocolate y el pan de maíz al que llaman tortilla que fabrica cada uno en su casa y este es su pan y aun suele ser toda su comida con un poco de pimiento que llaman chile [...] en agua con sal y una poca de manteca [...] feliz entre ellos el que puede añadir un pedazo de baca, tasajo o frijoles [...] sirve también para cebar los cerdos [...] los arrieros en los caminos y los caminantes en las posadas gastan tambien maiz para mantener sus recuas. ${ }^{6}$

4 Musset (1992: 159). Para el siglo XIX Juan Manuel Durán hace una breve e interesante presentación de algunos proyectos de construcción de canales en Chapala (Durán 1983: 96-106).

5 Florescano (1969: 170). La población de la ciudad de México se estima en 98.400 habitantes en $1742 ; 112.926$ en $1790 ; 137.000$ en 1803 y 168.846 en 1811 (García Acosta 1989: 21).

6 AGI, Audiencia de México, vol. 2.096, f. 33. La descripción es hecha por Arecheo (1771), el fiscal de la Real Hacienda en 1771. El estudio de los consumos puede modificar esta imagen, que señala al maíz como el alimento fundamental de la gente pobre y abunda en que "los indios solo se aflijen cuando les falta maíz". En efecto, si el maíz parece fundamental, también hay que señalar, como 
Por esto no es extraño encontrar que mientras el trigo observa una disminución en su consumo en la ciudad de México, de 450 gramos por persona y día en 1772, 400 en 1803, a 300 en 1815; el maíz, por su parte, parece aumentar, como lo reflejan las cifras de consumos con que contamos:

Cuadro 1: Consumos en la ciudad de México en 1742 y 1791

\begin{tabular}{lrrlcr}
\hline Maíz & 1742 & $150-160.000$ & Fanegas & 1791 & 351.672 \\
Trigo & 1742 & 2.000 .000 & Arrobas & $\begin{array}{c}1791 \\
\text { (harina) }\end{array}$ & 1.560 .000 \\
Carneros & 1742 & 300.000 & Cabezas & 1791 & 278.923 \\
$\begin{array}{l}\text { Toros, novillos, } \\
\text { vacas }\end{array}$ & 1742 & 15.500 & Cabezas & 1791 & 16.750 \\
Cerdos & 1742 & $24-25.000$ & Cabezas & 1791 & 50.576 \\
\hline
\end{tabular}

Fuente: Para 1742, Villaseñor y Sánchez; para 1791, Revillagigedo, según Romano (1998: 215).

Sobre la base de este cuadro, Romano afirma que, entre 1742 y 1791 , hay una reducción en el consumo de trigo y de carne de carnero, toro, novillo y vaca, y un aumento del maíz y de la carne de cerdo; una "evolución de productos 'nobles' hacia productos más 'corrientes"” (Romano 1998: 217).

Si esta es la tendencia general de los consumos en la ciudad de México, lo que nos interesa resaltar en este artículo es que una buena parte de estos productos circulaban por los caminos de agua de Chalco a la ciudad de México. Esto es particularmente cierto para el maíz que provenía en su mayor parte de las haciendas productoras de la región de Chalco que, con una producción anual promedio de unas $250 \mathrm{mil}$ fanegas de maíz durante el siglo XVIII, servían para abastecer el consumo anual de la ciudad, que no sobrepasaba la cifra de 200.000 fanegas anuales (Florescano 1969: 184; Gibson 1967: 337). Además, en

hace Gibson, que en las dietas de los indios los peces y pájaros acuáticos y los productos de la agricultura chinampera eran muy apreciados (Gibson 1967: 9). También lo serán otros productos, como el frijol, el garbanzo, el chile y tantos otros de los cuales apenas tenemos datos. Como bien señala Romano: "tampoco los pocos elementos de los cuales se dispone sobre el consumo de bienes alimenticios nos permiten ir demasiado lejos" (Romano 1998: 217). 
sus haciendas se recojían unas 60 mil fanegas anuales de trigo, que era transportado, al igual que el maíz, por medio de canales navegables a la ciudad de México para ser vendido en la Alhóndiga. ${ }^{7}$ Esto no era nuevo, ya desde 1709 se registraban 1.419 canoas que transportaban por los canales de Chalco 97.330 fanegas de maíz y en 1710, 3.463 canoas transportaban 115.120 fanegas por medio de 140 embarcaciones que entraban diariamente a la ciudad de México por el canal de La Viga.

Esto para no hablar de los productos del lago de Chalco que, a través de los escasos datos que nos llegan para otros periodos, suponen un consumo en la ciudad de México de más de dos millones de patos al año en el siglo XVIII, de un millón de peces en el XVI, las aves migratorias llegaban a la cuenca en un promedio de cinco millones anualmente. Si a esto agregamos los insectos, las serpientes, ranas, sapos y ajolotes, las plantas silvestres comestibles, algas y tortugas, entonces, estamos hablando de una gran cantidad de productos que consume y distribuye la economía indígena a través de los canales navegables y que escapan al registro de las fuentes. ${ }^{8}$

7 Según Gibson, fuera de la provincia de Chalco, las haciendas producían otros productos: trigo, cebada, frijoles, paja, ovejas, reses, caballos y mulas (Gibson 1967: 337).

8 Véase Gibson (1967: 348, 351) y Espinosa (1996: 388). Para el maíz, Musset (1992: 154). A falta de mejores datos, permítasenos presentar esta larga cita de Payno, quien describe la vida en un pueblo mexicano a finales del XIX de la siguiente manera: "No deja de ser curioso saber como vive en las orillas de la gran capital esta pobre y degradada población. Ella se compone absolutamente de los que se llamaban macehuales desde el tiempo de la Conquista, es decir, los que labraban la tierra; no eran precisamente esclavos, pero si la clase ínfima del pueblo azteca que, como la más numerosa ha sobrevivido ya tantos años y conserva su pobreza, su ignorancia, su superstición y su apego a sus costumbres; su proximidad a la capital no le ha servido ni para cambiar sus hábitos y su situación, ni para proporcionarles algunas comodidades. Los hombres que habitan ese lugar, que unos llaman Las Salinas, otros San Miguelito y la mayor parte lo confunden con Tepito, ejercen diferentes industrias. Unos con su red y otros con otates con puntas de fierro, se salen muy tempranito y caminan hasta el lago o hasta los lugares propios para pescar ranas. Si logran algunas grandes, las van a vender a la plaza del mercado; si sólo son chicas, que no hay quien las compre, las guardan para comerlas. Otros van a pescar juiles y a recoger ahuautle; las mujeres por lo común recogen tequesquite y mosquitos de las orillas del lago, y los cambian en la ciudad, en las casas, por mendrugos de pan y por venas de chile. Las personas caritativas siempre les dan una taza de caldo y alguna limosna en cobre. Otras se van a las milpas de las haciendas y ranchos cercanos a cortar quelites y verdola- 
La explicación de la importancia del transporte por canales es sencilla y tiene que ver con las ventajas comparativas de este transporte. $\mathrm{Si}$ se ha señalado que una de las causas del atraso económico de México fue la de no contar con vías navegables que facilitaran el transporte interno de mercancías y hombres. ${ }^{9}$ También sabemos que la mejor forma de facilitar el tráfico interno, antes de la llegada del ferrocarril, era a través del sistema de canales navegables, ya que un arriero transportaba una carga de 23 kilos a una distancia de 21 kilómetros por día; una mula recorría la misma distancia con 105 kilos de carga, una carreta viajaba de 16 a 19 kilómetros con una carga de 1.800 kilos, mientras que una trajinera se deslizaba 30 kilómetros con una carga de 6.800 kilos. $^{10}$ Este era la importancia decisiva de los caminos de agua.

Sin embargo, contemporáneos, como el sabio J. A. Alzate, sólo dan cuenta de los canales, indicándonos con flechas lo que aparentemente sería la circulación de las canoas (véase mapa 1). En efecto, en el mapa de Alzate de 1767 observamos una serie de flechas que indican el tráfico de los lagos del sur hacia la ciudad de México. Allí apa-

gas, a recoger semilla de nabo, y aún suelen robarse, cuando no las ven los guarda-milpas, algunos elotes. La población, pues, sale en las mañanas a ejercer pequeñas industrias y regresa por la tarde habilitada de una manera o de otra de gordas, de elotes, de tortillas, de pedazos de pan, de restos de comida y de algunas monedas. En la ciudad han comido cualquier cosa; y en la tarde, al regreso, completan la alimentación con los animalillos sobrantes que no pudieron vender [...] En la estación de aguas hacen sus pozos y sus atajaderos en el punto que creen mas conveniente de las orillas del lago, y recogen su cosecha de sal [...] Años hay que las lluvias son abundantes y entonces los potreros de Aragón se inundan, las obras hechas para recoger la sal son arrebatadas por las corrientes y el pueblecito queda formando una isla; si las aguas suben, entran en las casas y los habitantes tienen que abandonarlas, se van a Zacoalco o a otros pueblos y haciendas vecinos a acomodarse como peones" (Payno 1968: 12).

9 Véase para el siglo XVIII, Ortiz de la Tabla (1978). Para el XIX, Haber (1989) y Coatsworth (1990).

10 Hassig (1990). Estos cálculos de Hassig son aproximados pero coinciden con otros casos. P.ej., Calvo $(1997: 36,38,45)$ señala que una carreta viajaba con 1.840 kilos de carga, un cargador con 30 o 40 y una mula con unos 115 . H. Ward señala, en cambio, que una mula en 1823 transportaba 138 kilos a una distancia de 16,7 kilómetros, cosa en la que coincide con Suárez Argüello, como señala Flores Clair (2000). Quizá el cambio del XVI al XVIII hace que al aumentar la carga disminuya la distancia. También sabemos que en Chiapas los indios cargadores de café transportaban una carga de cerca de cincuenta kilos diarios a finales del XIX. Agradezco esta información a Jan Rus. 


\section{Mapa 1: Caminos de agua en la cuenca de México, 1767}

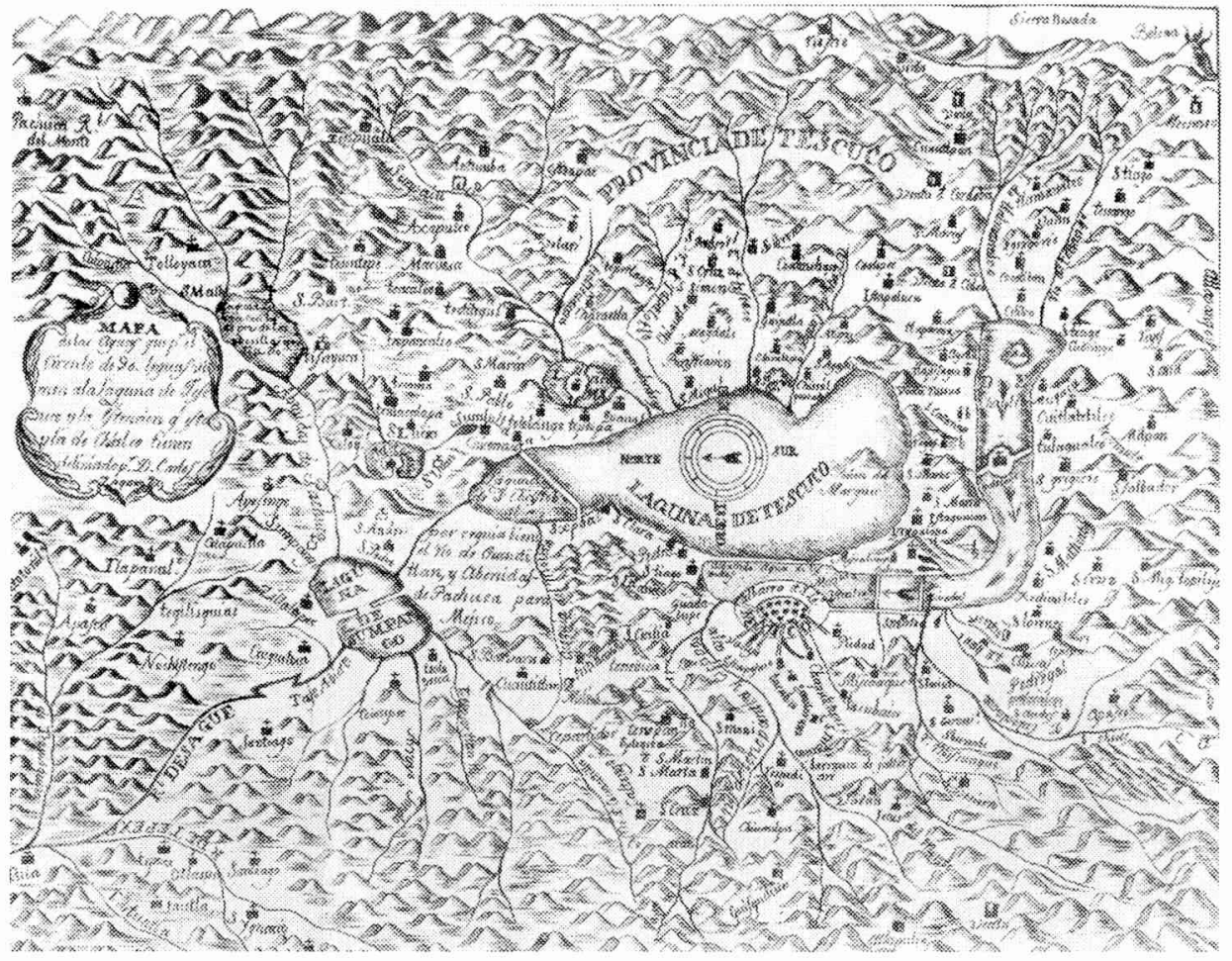

Fuente: Alzate Ramírez (1831, II: apéndice). 
recen los pueblos circundantes al lago de Chalco: Santa Catarina, Venta Nueva, Tlapizagua, Ayotla, Tlapacoya, Chalco, Santiago, Ayozingo, Mesquique, Cuitlatetelco, Tuliagualco. En medio, dividiendo las lagunas de Chalco y de Xochimilco, aparece Tláhuac. Esta laguna bordea en su parte sur los pueblos de San Gregorio, Nativitas, Xochimilco y San Lorenzo y en su borde oriental los pueblos de Culhuacán, Mexicalcingo, Iztacalaco y la Magdalena. En el camino de Chalco a México aparece la calzada de San Antonio que llega hasta el albarradón de San Lázaro y que forma dos cortes en Culhuacán y en Mexicalzingo para el control de las aguas de la laguna. Como dato interesante, en la zona de Iztacalco aparecen representadas las chinampas. ${ }^{11}$

Otros cronistas sólo mencionan la existencia de acequias que corrían hacia la laguna por donde los vecinos de México recibían multitud de productos. ${ }^{12}$ No será sino hasta el siglo XIX, con los proyectos de navegación por la laguna, que tendremos detalles sobre la navegación por canales en la época colonial. Allí encontramos que los caminos de agua se formaron por medio de canales navegables, del cual el principal partía del pueblo de Chalco, atravesando el lago de este a oeste, pero no en línea recta, llegando a Xico, de ahí a Tláhuac, donde se dividían las aguas del lago de Chalco y Xochimilco por medio de un dique. En seguida se recorría el pueblo de Tomatlán y de ahí se unía al canal de la Viga que de sur a norte bordeaba los pueblos de San Francisco, Mexicalcingo, San Juanico, Iztacalco y Santa Anita, hasta llegar al centro de la ciudad en donde se desembarcaban los cereales para ser almacenados en las trojes de la alhóndiga (mapa 2).

La distancia total que se recorría era de aproximadamente trece leguas $(72 \mathrm{~km})$, por caminos tortuosos que seguían las embarcaciones en unas dieciséis horas de viaje. El hecho de que el camino fuera así obedecía a que, al formar sus chinampas, los campesinos llevaban a pastar sus ganados en tiempos de secas y había terrenos que, ya fuera por el peso del ganado o por otros factores, se desprendían de la "cinta" principal formando "bandoleros" o fracciones que mudaban de

11 Alzate Ramírez (1767). Alzate se basa en el mapa elaborado por D. Carlos de Sigüenza.

12 Véase Sierra (1973: 26). Allí el autor también menciona como las acequias que había en México en 1637 eran la de Palacio, de un largo de 3.000 varas; la del Carmen, 1.095 varas; la de la Merced de 139 varas; la de Tezontlale de 1.656; la de Santa Ana de 2.840 y la de Mexicalcingo con 2.850 . 
Mapa 2: Dibujo de las lagunas de Texcoco y Chalco, 1767

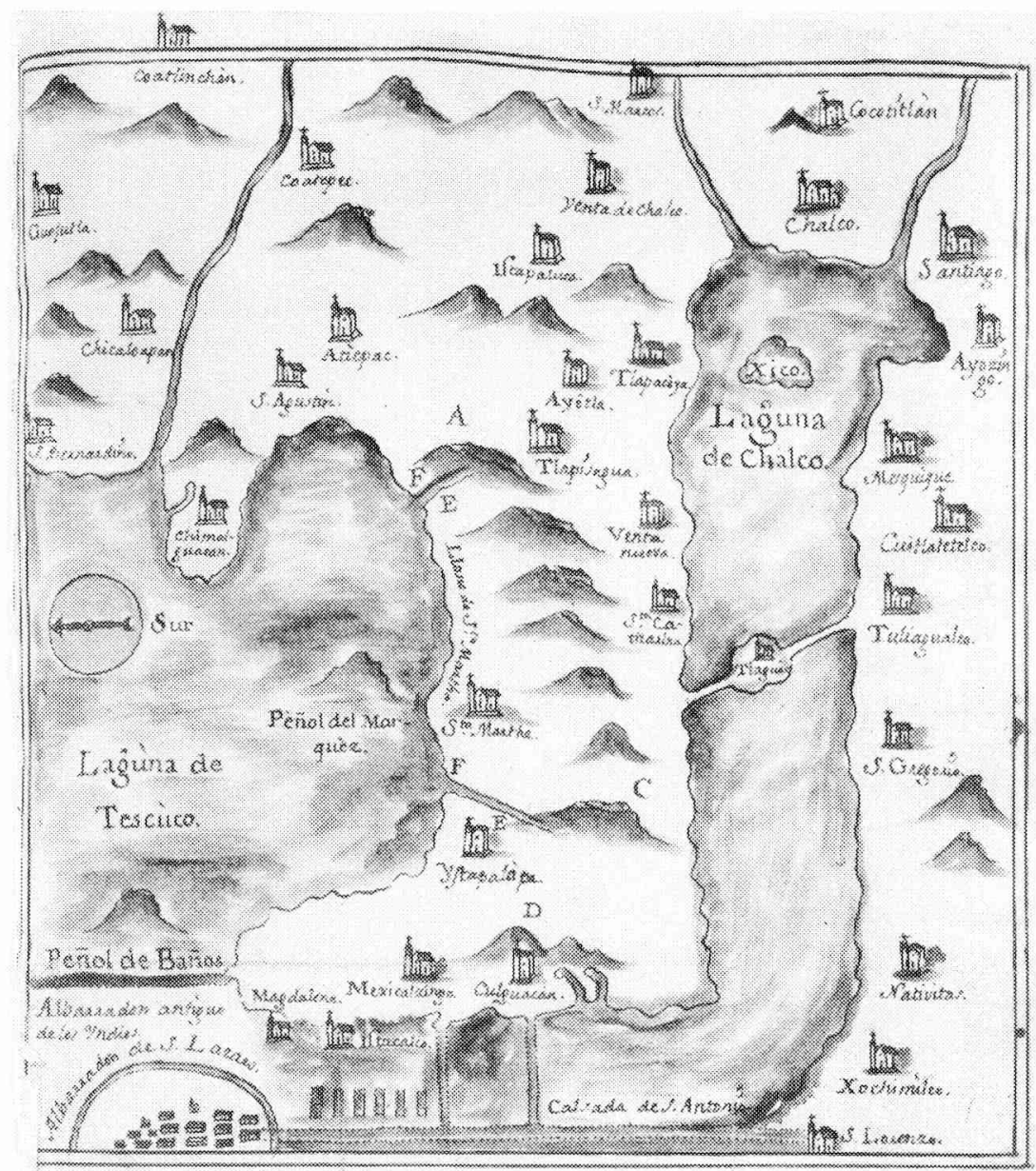

Fuente: Alzate Ramírez (1982). 
lugar. Estos "bandoleros" impedían la correcta circulación de las embarcaciones y además la vegetación de los lagos también se acumulaba en ciertas partes, lo cual impedía el tráfico en línea recta de las canoas. Por ello, Orozco y Berra, afirmaba que los indios se habían visto obligados a romper en los lugares convenientes, canales o acalotes, que no siguen la línea recta, sino que se desviaban de esa dirección, formando un trayecto más largo, lo cual exigía mayor esfuerzo y tiempo. Para compensar esto, el tráfico se hacía generalmente durante la noche para evitar el desgaste de los remeros por las altas temperaturas (Orozco y Berra 1864: 163).

A este canal principal se unía el canal de San Lázaro, que conectaba la ciudad con el lago de Texoco, también al interior del lago de Chalco había pequeños canales o acalotes que servían para conectar los embarcaderos vecinos, como el de Santa Bárbara, que pasaba por Tlapacoya para unirse en la isla de Xico al canal principal.

Los embarcaderos que existían en torno al lago de Chalco a fines del XVIII, además del ya mencionado de Santa Bárbara, eran el de la Colecturía de la Santa Iglesia Catedral Metropolitana, Retana, San Joseph, Gordon, San Antonio Abad, San Ysidro, la Soledad y San Joseph. Nueve embarcaderos que nos muestran la intensidad del tráfico de mercancías y hombres, como veremos en seguida. ${ }^{13}$

13 En efecto, en el pueblo de Chalco estaban los siguientes: el embarcadero de la Iglesia Catedral Metropolitana, que era administrado por don Domingo Estevanes, quien recibía el maíz de los diezmos de los agricultores de Chalco y los remitía a la alhóndiga de la Iglesia en la ciudad de México; el de San Joseph, era administrado por don Miguel Acoste y su dueño era Santhiago García; el de Retana, propiedad de la hacienda del mismo nombre de doña Yzabel Gil de Rosas y administrado por don Joseph Araujo. También estaba el de Gordon, pero ya arruinado, en el que su propietario, Francisco Luzuriaga, declara sólo embarcar leña. En el pueblo de Ayotla había dos: el de San Antonio Abad, propiedad de Bonifacio Antonio Lopes, y el de la hacienda San Ysidro, propiedad del hacendado don Joseph Narbarte y administrado por don Juan de Herrera. Luego en el pueblo de Ixtapalucan estaba el de Santa Barbara, propiedad de doña Juana Theresa de Cifuentes y administrado por don Nicolás de Horta. En el pueblo de Ayotzingo estaba el embarcadero de la Soledad, propiedad de don Lorenzo López y Arteaga, y el de San Joseph de El Agueguete, propiedad de la hacienda del mismo nombre de doña Antonia Brizuela y administrado por don Joseph Antonio Guerrero. 


\section{La producción y el tráfico de mercancías}

El comercio de mercancías entre Chalco y la ciudad de México era intenso: azúcares y frutas de la tierra caliente; carbón, leña y madera de las montañas de la Sierra Nevada; flores, frutas y hortalizas cultivadas en las chinampas; peces, aves acuáticas y productos de la laguna; pero sobre todo una gran cantidad de cereales cultivados en las haciendas y pegujales de la región de Chalco (Martínez 1996: 254).

En efecto, el alimento principal de la gente pobre en la ciudad de México y en el país entero era el maíz. En torno a sus cosechas se ajustaba la vida y el calendario de la gente. Con una mala cosecha de esta semilla estallaban terribles crisis de subsistencia. Por esto Gibson (1967: 331) afirmaba que con tantas cosas tan comprometidas en esta agricultura, la posibilidad de hacer innovaciones en su cultivo era imposible, en cambio los sistemas tradicionales de cultivo que habían servido para abastecer una población no sólo de cultivadores, sino de consumidores como los de la ciudad, eran la regla (Florescano 1969; Gibson 1967: 331).

Por lo anterior no es extraño encontrar declaraciones de la importancia decisiva del maíz. A la cita de Arecheo (1771) que hemos introducido antes, podemos agregar la del conocido agricultor Juan Antonio Yermo quien, a requerimiento de su majestad, le envía un informe sobre todo género de agricultura en la Nueva España fechado en 1788 y allí asienta:

El primer ramo de la Agricultura es el de las siembras de Maiz por ser la semilla con que se alimentan a lo menos las quatro quintas partes de personas de este Reyno, y casi todas las bestias de carga, silla y tiro, de minas, Ingenio de azucar y de coches, porque para solo las de estos ultimos se [g]asta cebada en México, Puebla y tal qual lugar del Reyno [...] (Yermo 1788: 82).

Para hacer frente a esta demanda maicera, las haciendas y las tierras de Chalco se habían convertido en el principal centro productor de este grano, prácticamente éste tenía el monopolio que abastecía a los voraces consumidores de la ciudad de México (Florescano 2000: 102; Gibson 1967). La región contaba con ventajas especiales: su proximidad a la ciudad, su abundante población, su tráfico por canales, sus tierras llenas de humus arrastrado por los limos de las aguas del lago y detritus vegetales, en fin, sabemos que la hacienda comercial produc- 
tora de maíz, llegó a su máximo desarrollo en Chalco en la época colonial.

En efecto, apenas había indicios de falta de maíces en la alhóndiga e inmediatamente los oficiales reales recibían las órdenes de ir a Chalco para evitar la regatonería y el extravío de maíces; en su lugar, debían establecer medidas para hacer venir todos los maíces de Chalco "en derechura" a la alhóndiga. Gracias a sus informes podemos conocer con detalle la producción y el intercambio de maíces por los canales de Chalco.

En la segunda mitad del XVIII, de acuerdo a nuestros datos, raro fue el año en que estos hacendados no introdujeron, de manera oficial, más de cuarenta mil fanegas de maíz; en cambio hubo diez años en los que llegaron casi o sobrepasaron las sesenta mil fanegas y seis años en los que enviaron más de cien mil fanegas. Por ello, las estimaciones ya apuntadas de Gibson (1967: 337) de que un rendimiento promedio de las haciendas de Chalco en el XVIII era de 250 mil fanegas en 46 haciendas. $^{14}$

\section{Cuadro 2: Maíz vendido en la alhóndiga de la ciudad de México en la segunda mitad del siglo XVIII}

\begin{tabular}{lccc}
\hline Año & $\begin{array}{c}\text { Fanegas de maíz } \\
\text { vendidas en alhóndiga }\end{array}$ & Año & $\begin{array}{c}\text { Fanegas de maíz } \\
\text { vendidas en alhóndiga }\end{array}$ \\
\hline 1758 & 42.885 & 1797 & 70.976 \\
1759 & 66.515 & 1798 & 46.960 \\
1763 & 35.280 & 1799 & 48.160 \\
1764 & 36.416 & 1800 & 63.236 \\
1765 & 43.441 & 1801 & 44.128 \\
1766 & 41.610 & 1802 & 44.672 \\
1767 & 25.478 & 1803 & 60.672 \\
1771 & 111.360 & 1804 & 40.064 \\
1772 & 114.200 & 1805 & 43.468 \\
1773 & 118.976 & 1806 & 58.400 \\
1774 & 101.760 & 1807 & 55.840 \\
1775 & 67.424 & 1808 & 40.128 \\
1784 & 37.884 & 1809 & 53.184 \\
1785 & 68.088 & 1810 & 67.968
\end{tabular}

14 Gibson (1967: 337). Florescano (1969: 19) señala que la media de maíz vendido en la alhóndiga en años de buenas cosechas era de 36.680 fanegas, mientras que en los de malas cosechas era de 110.144. 


\begin{tabular}{cccc}
\hline Año & $\begin{array}{c}\text { Fanegas de maíz } \\
\text { vendidas en alhóndiga }\end{array}$ & Año & $\begin{array}{c}\text { Fanegas de maíz } \\
\text { vendidas en alhóndiga }\end{array}$ \\
1795 & 67.904 & 1811 & 62.904 \\
1796 & 110.144 & 1812 & 104.400 \\
\hline
\end{tabular}

Fuentes: Para 1758 y 1759, AGN, Alhóndigas, vol. 2; para los demás años, Florescano (1969).

En efecto, para poder abastecer el consumo de la gran ciudad era necesario producir una cantidad tal de maíces que una vez descontados el diezmo, las raciones a los trabajadores, el consumo en la hacienda y la inevitable regatonería, fuera capaz de satisfacer la demanda del habitante de México. Por ello el férreo control de la administración real para hacer llegar los maíces a la alhóndiga y así evitar hambrunas y carestía.

En 1759, por ejemplo, en un año señalado como de "mala cosecha" los oficiales de la alhóndiga se inquietan por la escasez de maíces provenientes de Chalco. Para estudiar la situación se designa en 1760 y luego se le envía al licenciado Francisco del Barrio y Lorenzot, abogado de la Real Audiencia, a inspeccionar haciendas y embarcaderos para ver el estado de los maíces de Chalco. Su visita es un excelente termómetro que nos muestra la temperatura de Chalco en ese año.

Por su informe sabemos que 37 haciendas, 6 ranchos y unos pegujales en Ameca, produjeron un total de 153.617 fanegas de maíz en la cosecha del 1759. De estas hay que descontar el diezmo y consumo local de $\mathbf{8 8 . 5 0 2 ~ f a n e g a s ~ y ~ s e ~ t i e n e n ~ m a ́ s ~ d e ~ s e s e n t a ~ m i l ~ f a n e g a s ~ l i s t a s ~}$ para ser dirigidas a la alhóndiga de la ciudad de México. ${ }^{15}$ No obstante, el visitador señala que era muy común que los hacendados declarasen menos maíces de los que tenían para poderlos negociar a voluntad y no dirigirlos al mercado controlado de la alhóndiga y estima en unas cien mil las fanegas que se podrían enviar ese mismo año.

Las haciendas que más produjeron maíz, por encima de las cinco mil fanegas, fueron las de Tequimilco, Atoyac, Atempa, Chiconquiahuitl, Zentlalpan, El Moral, Atlapango, San Andrés Retana y San Nicolás, así como el rancho de Juchitepec. ${ }^{16}$ Otra cosa que también vale

15 AGN, Alhóndigas, vol. 1, exp. 6.

16 Cabe subrayar que más de un siglo después, en 1889, estas haciendas siguen siendo grandes productoras de maíz y en algunos casos como en Tequimilco, Chiconquiahuitl, El Moral, Atlapango, Retana y San Nicolás, la producción era mayor en 1759 que en pleno Porfiriato. 
la pena subrayar es que no obstante ser buenas productoras, Atoyac y Juchitepec no logran enviar granos a la alhóndiga porque todos los consignan como gastados en la hacienda. En este caso también están otras unidades productivas como: Santa Cruz, Archicofradía, Tomacoco, Miraflores, Jocoatlaco, Tlalmimilolco, Guadalupe, Los Jardines, Nestipan, Ocoyoacac, Acuautla, Atempilla, Tescaltengo, San José, Joyoacán, y desde luego los pegujales de Amecameca.

Son pocas unidades, en realidad, las que monopolizan el comercio del maíz. Los terribles labradores de Chalco, el "nervio de la república" estaban en manos de unos cuantos dones y doñas: Miguel Sáenz de Sicilia (Tomacoco y Archicofradía), Ángela Calzado (El Moral), Manuel de Rivas Cacho (San Nicolás Zavaleta, San José y el rancho de Abelar), Bernardo Ramírez (Atempa, Atopac, Atlapango), marqués de Castañiza (Zoquiapan, El Olivar, El Carmen y Acuautla). Más adelante volveremos a ellos, por ahora sólo queremos señalar que estos personajes enviaban sus granos a la alhóndiga de México en canoas a través de los embarcaderos.

Estas canoas eran grandes y pesadas embarcaciones de madera que eran accionadas por uno o más remeros generalmente indígenas. Éstos, ayudándose de un palo largo que enterraban en el suelo lodoso, propulsaban el movimiento de las embarcaciones que tenían nombres como "San Cayetano", "San Juan Nepomuceno", "San Ignacio", "Ysasi", etc. En el mes de mayo del mismo año de 1760, por ejemplo, estas embarcaciones habían transportado 12.528 fanegas de maíz a través de los puertos de Chalco. Para el pago de la alcabala, las canoas debían viajar con una boleta indicando el puerto de embarque, la cantidad de productos transportados y el destino final, pero había muchas canoas que viajaban sin boleta. En efecto, con pretextos como el de que transportaban artículos libres del pago de la alcabala, como los productos de la tierra, o que eran para el diezmo de la Santa Iglesia Catedral, cada mes había un tráfico de varios miles de fanegas de maíz que no eran transportadas con boletas. En ese mes de mayo se reportaron cerca de cinco mil fanegas extraviadas y sólo 7.538 llegaban directamente a la alhóndiga. Por ello las medidas adoptadas por la Corona de enviar al licenciado Francisco del Barrio Lorenzot para vigilar que el tráfico se realizara sin extravíos y directamente hacia la 
Alhóndiga. El castigo para los infractores, contrabandistas de agua dulce, era de "apercivimiento y dos mil pesos de multa". ${ }^{17}$

A juzgar, entonces, por esta información el tráfico anual en años de malas cosechas era cercano a las ciento cincuenta mil fanegas de maíz, de las cuales una tercera parte no llegaba a la alhóndiga, utilizando medios como desviarlas por Texcoco, hacerlas pasar por maíz del diezmo o circularlas por los canales en claro contubernio con los guardas de las garitas. Para evitar estos males que afectan el abasto de maíces, la comisión a Barrio Lorenzot es triple: que se dirijan los maíces "en derechura" hacia la alhóndiga, que no haya extravíos y que se conozca el volumen de lo producido en Chalco para poder calcular el abasto.

Por ello, el visitador consulta los libros de los embarcaderos, visita las trojes de las haciendas, consulta sus libros de gastos, de cosecha y diezmos, se entrevista con los guardias de las garitas, y así, sobre la base de esta información, hace publicar una serie de bandos donde se establecen las multas y castigos para los infractores. ${ }^{18}$

Sin embargo, las medidas no son suficientemente eficaces, ya que diez años después, en 1770 , se designa al señor mariscal de Castilla como juez comisionado para evitar la regatonería de maíces. Por sus informes y los del comisionado Joseph Feijo, sabemos que en el año de 1769, consignado como de escasa cosecha, 39 haciendas de Chalco produjeron 72.351 fanegas de maíz. Casi la mitad que diez años antes. Ahora, sin embargo, también se consigna la producción de trigo, 16.935 fanegas y de cebada en 12.435 fanegas. Sabemos que la escasez de maíz producía un aumento en la demanda del trigo y que Chalco y Texcoco producían el sesenta por ciento del trigo consumido en

17 AGN, Alhóndigas, vol. 2, exp. 4. Para el contrabando en el siglo XVIII, véase Romano (1998: 35-101); para el XIX, ver Bernecker (1989; 1992).

18 Florescano (1969: 191) en su obra clásica sobre los precios del maíz señala que entre 1721 y 1778, la gran hacienda de Chalco está en peligro por la ofensiva de la pequeña propiedad y las cosechas relativamente abundantes. En cambio entre 1779 y 1810 , el alza constante de los precios, proporcionaron a los grandes hacendados los más altos beneficios del siglo y los grandes agricultores pasaron de las lamentaciones al regocijo, utilizando tácticas como las ventas fuera de la alhóndiga: en 1795, de 160.000 fanegas registradas en las aduanas de la ciudad sólo 67.904 se introdujeron en la alhóndiga. Sin embargo, hemos visto, que estas tácticas no comienzan en la época de las alzas de precios, sino por lo menos desde 1759 y parecen ser una estrategia constante de los hacendados. 
la ciudad de México. Sin duda, esta diversificación en los cultivos incide en la menor producción de maíces. ${ }^{19}$

Las mayores haciendas productoras de maíz son: El Moral (12 mil fanegas), Zavaleta (7.500), San Joseph Buenavista (6.000), San Joseph Temporalidades (6.000), Tequimilco (5.000), Retana (4.000) y Guadalupe (4.000).

\section{Cuadro 3: Principales haciendas productoras de maíz en Chalco (fanegas), 1759 y 1769}

\begin{tabular}{lrr}
\hline Hacienda & $\mathbf{1 7 5 9}$ & $\mathbf{1 7 6 9}$ \\
\hline San Nicolás o Zavaleta & 13.881 & 7.500 \\
San Andrés o Retana & 10.000 & 4.000 \\
El Moral & 9.100 & 12.000 \\
Chiconquiahuitl & 7.000 & 3.000 \\
San Joseph Buenavista & 4.000 & 6.000 \\
San Joseph Temporalidades & 3.500 & 6.000 \\
Tequimilco & 5.000 & 5.000 \\
\hline
\end{tabular}

Fuente: Para 1759, AGN, Alhóndigas, vol. 2; para 1769, AGI, Audiencia de México, 2.096 .

Aquí, valdría la pena señalar que casi son las mismas haciendas de diez años antes, pero algunas que antes aparecieron como grandes productoras, por ejemplo Zentlalpan, se han convertido en una sola propiedad ahora con el nombre de Retana y, por tanto, es difícil de explicar el porqué de la baja en la producción de maíz. Una hipótesis a señalar es que en ese año, 1769, un conjunto de haciendas no registran producción de maíces. ${ }^{20}$ Estas haciendas, diez años antes habían producido unas veinticuatro mil fanegas de maíz, lo que explicaría el porqué de la baja cantidad en el 69 . No tenemos datos sobre si se trata de una falla en la fuente o si ese año las haciendas perdieron sus culti-

19 Florescano (2000: 81). Con todo se sigue señalando la importancia de Chalco como productor de maíz: "[...] siendo como es la provincia de Chalco principal, y quasi el todo para proveer a esta capital de mayzes, sube de grado el daño, y demanda el mas eficaz remedio" (AGN, Alhóndigas, vol. 1, exp. 6; Florescano 2000: 102).

20 Nuestra Señora del Carmen, Guatongo y Coxtitlan, Santa Fe Tetelco y Ahuehute, San Gerónimo, San José Axalco, Aculco y El Olivar, San Nicolás de los Álamos, Atempa, Guadalupe Teposuapan, San Pedro Mártir, Archicofradía y Guadalupe. 
vos, pero sabemos que en 1768 se reporta un año de sequía y lluvias fuera de estación en el valle de México, con la consecuente "escasez de granos" y precios altos del maíz que pudo haber afectado la cosecha que estudiamos. En efecto, en la década 1760-1769 se registran cinco sequías en el valle de México, mientras que en la década anterior sólo se registra una en junio de $1755^{21}$

En cambio, sabemos que ahora las haciendas registran una producción de otros cereales, como el trigo con 16.935 fanegas cosechadas y cebada con 12.435. Muy detrás están el frijol -menos de mil fanegas- y el alverjón. Con fines comparativos, la producción de estos cereales en 1889 fue de 26.370 fanegas para el trigo y unas 30.000 para la cebada. El trigo era muy apreciado por el gremio de panaderos de la ciudad de México y competía con el trigo del Bajío, muy apreciado por su blancura y su calidad excelente para el pan. No era casual, entonces, que en Chalco existieran cinco molinos y que en tres de ellos sus dueños estuvieran vinculados por parentesco, formando un grupo poderoso.

Estos granos como anotamos en el informe de Yermo, pero también los olotes, residuos del maíz, se tenían que compartir con la cabaña ganadera compuesta en su mayoría por ganado menor con 11.112 cabezas, donde la mayor parte eran ovejas (7.407) y carneros (2.804). El ganado mayor, la mitad casi del menor, con 5.769 cabezas estaba compuesto en su mayoría por las bestias de tiro como los bueyes (3.508) y los caballos y mulas (978). Las vacas (771) y los cerdos (250) eran poco importantes. ${ }^{22}$ Vale la pena mencionar que en 1889 el ganado menor estaba compuesto por 8.704 cabezas, mientras que el mayor con 6.929 cabezas había sufrido un incremento importante de las vacas, lo que reflejaba el cambio urbano donde la leche y sus derivados comenzaban a ganar la partida a los productos de cabra. Sin embargo, en términos absolutos la cabaña ganadera no se incrementa mucho en el transcurso de un siglo, lo que demuestra que la superficie

21 La fuente es más detallada que la de diez años antes y por ello me parece que es más confiable, pero no ofrece datos sobre el clima o la pérdida de cosechas. Para la sequía, véase Florescano/Pérez/Sancho (1980: 756) y Florescano (2000: Apéndice 3 ).

22 Hay que enfatizar, como lo hacen contemporáneos como Arecheo (1771), Yermo (1788) y lo recuerda Romano (1998), que los mulos, cerdos, caballos y aves también son consumidores de maíz. 
de las haciendas no era suficientemente grande para permitir el incremento del ganado; en efecto, en 1889, a falta de datos para 1769 , 18 haciendas son menores de mil hectáreas, 7 menores de 3.000 y sólo cinco sobrepasan las tres mil. ${ }^{23}$ Si consideramos que en 1741 se registran 57 haciendas y ranchos y en 1792 son 77, entonces el tamaño de las unidades debía ser aun menor al de 1889 , donde se registran 30 haciendas y 15 ranchos. $^{24}$

Además del tráfico por canales que establecía un intenso comercio con la ciudad de México, los productos de Chalco y de su comercio con otras regiones se consumían también en el mercado local, en forma de raciones y consumo para los habitantes de haciendas y pueblos, y en el mercado perilocal, destinando algunos productos para los tianguis de los pueblos, donde el más famoso era el que se realizaba los viernes en Chalco. ${ }^{25}$ Como este es un comercio que no pasa por los canales y motivaría otro artículo, sólo queremos señalar este asunto para regresar, ahora sí, a los personajes que se encargan del comercio local y el regional.

En la cúspide está una pequeña élite compuesta por grandes comerciantes y hacendados. Allí están el marqués de Rivas Cacho, caballero de la Orden de Santiago y alguacil mayor del Santo Tribunal de

23 Chevalier (1952: 113) señala que en 1543 se establece que los sitios para ganado mayor debían medir 3.000 pasos y los destinados a las ovejas, 2.000. Así mientras que una caballería, o tierra de labor media 43 hectáreas, una estancia de ganado era cercana a las 1.750 ha y 780 ha si era de ovinos. Estas dimensiones eran demasiado grandes para Chalco.

24 Esta es sólo una conjetura, ya que en 1792 el territorio de la provincia de Chalco es mayor que el distrito del mismo nombre creado en el XIX, pues incluye algunos territorios de frontera con Morelos. Para el siglo XVIII, puede verse Gerhard (1986) y para el XIX, Tortolero (1995).

25 Por ello, 21 unidades productivas declaran no tener maíces libres para enviar a la alhóndiga en 1760, es decir, más de la mitad de las que fueron inspeccionadas por F. del Barrio. En relación a los tianguis, es decir, las ventas cotidianas en la plaza del mercado, entre 1764 y 1768 , se recaudó un total de 7.191 pesos en la Receptoría de Chalco por concepto de alcabalas. La descripción del comercio en el tianguis de Chalco hecha por los hacendados, como el marqués de Rivas Cacho, es la siguiente: "El mercado o tianguis de Chalco se hace el viernes de cada semana; de el se abastece toda la circunferencia, porque el Pueblo es en si muy corto: los indios y gente pobre no tienen por lo regular con que comprar el viernes lo que necesitan para toda la semana [...] Por este motivo el tendero que tiene principal, lo compra por junto y diariamente va expendiendo para el abasto de los Pueblos lo que sus havitadores no pudieron comprar el dia viernes" (AGI, Audiencia de México, 2.096, f. 15). 
la Inquisición, el marqués de Castañiza, don Bernardo Ramírez, don Diego Ballesteros, don Miguel y don Felipe Sáenz de Sicilia y don Pedro Gil de Rozas. Estos personajes han sido caracterizados como un patriarcado, poseedores de grandes cantidades de tierra, ligados a comerciantes y políticos e integrados por el parentesco (Tutino 1976).

En efecto, la base de su poder está en la propiedad de la tierra. En 1773, por ejemplo, Manuel de Rivas Cacho era propietario de las haciendas de Zavaleta, San José y el rancho de Abelar; su fortuna se calculaba en cerca de un millón de pesos. El marqués de Castañiza tenía la posesión de las haciendas de Zoquiapan, El Olivar, El Carmen y Acuautla. Don Bernardo Ramírez poseía Atempa, Atopac, Atlapango y Los Jardines. Miguel Sáenz de Sicilia tenía la posesión de Tomacoco y Archicofradía (Artís 1993: 213).

Tierra y parentesco son dos mecanismos para que la élite funcione bien. Por ejemplo, la unidad productiva formada por las haciendas de Zavaleta y sus anexos, la hacienda del señor San José y el rancho de Abelar, junto con un embarcadero en Chalco, las hereda la nieta del marqués de Rivas Cacho, Gertrudis Ignacia de la Cotera. Don Miguel Sáenz de Sicilia y don Felipe Sáenz de Sicilia poseen tres haciendas en Chalco. Francisco de la Cotera, yerno del primer marqués de Rivas Cacho, adquiere tres ranchos en Chalco, para formar un mayorazgo. La familia La Cotera-Rivascacho, emparentaría con los condes de Jala, parientes a su vez de los Sáenz de Sicilia.

Don Pedro Gil de Rosas, propietario de la hacienda de Guadalupe y San José y A. Monterde, dueño de la de San Martín Cuautlalpan, eran nietos del matrimonio formado por Luis Monterde y Antillón y Catalina Lazo, fundadores de un mayorazgo valuado en 1717 en más de 450.000 pesos. El mayorazgo incluía haciendas ganaderas en Santa María de los Lagos y León, así como una casa en la ciudad de México y otra en Veracruz. ${ }^{26}$

En suma, esta élite tenía dos estrategias para conservar y acrecentar sus fortunas: el matrimonio y la formación de mayorazgos. ${ }^{27}$ Gertrudis Ignacia de la Cotera, por ejemplo, se casó con Antonio Rodríguez de Soria, segundo conde de San Bartolomé de Jala, propietario

26 Artís (1993: 215). La autora también menciona a otros miembros de la oligarquía como el marqués de Ulapa, propietario de la hacienda de Retana.

27 Ver Artís (1993: 12, 13), quien también señala que la Iglesia no fue propietaria importante en Chalco. 
de haciendas pulqueras y pulquerías en la ciudad de México, quien administra los bienes de su esposa. Fue él quien introdujo en la hacienda-molino de Zavaleta el cultivo del maguey que contaba con 7.000 plantas en 1784. El conde de Jala era pariente de los marqueses de Selvanevada, propietarios del mayorazgo Sáenz de Sicilia y, por ello, del molino de Tomacoco. Por su parte, el mayorazgo Sáenz de Sicilia se formó en 1764 y tuvo como dote principal el molino de Tomacoco; este mayorazgo estaba valuado en 60.000 pesos en su fundación, pero en 1776 se le añade una casa en la ciudad de México y sus propietarios obtienen un título nobiliario mediante el pago de 10.000 pesos, convirtiéndose en los marqueses de Selvanevada. El molino de Tomacoco estuvo vinculado durante 75 años, pero no es el único. También el de Miraflores lo estuvo por 130, entre 1674 y 1804, con el nombre de Mayorazgo de Vera Ureña.

Pero también estaban allí, junto a esta élite, algunos comerciantes y agricultores medianos, como don Francisco Xavier Cacho, arrendatario de la hacienda de Chiconquiahuitl, quien posee una de las mejores tiendas con productos de Puebla y la tierra caliente, además de encargarse del comercio de ganado mayor (vacas y 3.500 toros en un año). Otros se asocian a empresas de fabricación de ropa, como don Joseph Rubín o don Juan Joseph Ramírez, quienes poseen tiendas, unos telares para fabricar ropa, tocinerías y comercian con Puebla, la tierra caliente y Chalco. Otros en cambio se consagran a la distribución, como don Martín Gastea, Francisco Xavier Roldán y Agustin Ramos, para sólo citar a los comerciantes más importantes, los que están igualados por más de doscientos pesos en la región. ${ }^{28}$

Detrás de este comercio, más visible, como el de don Joseph Rubín, quien además de lo que hemos mencionado vendía crecidas partidas de harina, mandaba con frecuencia dos atajos para tierra caliente por azúcares y mieles, comerciaba con maderas y canoas y poseía cuatro telares, también aparecen los pequeños comerciantes que forman un tejido amplio entre los pueblos destinados a los pequeños in-

28 Recordemos que las igualas consistian en un impuesto concertado, cuyo monto era fijado en común acuerdo entre el recaudador fiscal y el contribuyente basándose en un cálculo aproximado del valor que podrían llegar a alcanzar las operaciones mercantiles o artesanales gravables a realizarse durante un año (Garavaglia/Grosso 1988: 37). 
tercambios (ver anexo 1). ${ }^{29}$ Aquí estamos frente a lo que Van Young (1992) caracteriza como hombres de origen desconocido y con frecuencia ambiciosos y hábiles, algunos de los cuales llegaron a poseer tierras pero que en general eran arrendatarios, con oficios diversos. Administraban propiedades rurales, invertían en el comercio regional, servían de corregidores y subdelegados y trasladaban productos a lo largo de la región. Compraban y vendían, daban órdenes e intercedían. ${ }^{30}$

\section{Consideraciones finales}

Con estos hombres queremos concluir nuestro artículo. Sin los canales navegables la fortuna de hacendados como don Manuel de Rivas Cacho no sería sin duda la misma. El poder enviar sus maíces por los caminos de agua en el momento en que los precios estaban altos era una táctica que no estaba al alcance de todos. En principio no la tenían los hacendados de Toluca que estaban obligados a enviar sus maíces por los caminos de tierra firme, antes de las épocas de lluvias que paralizaban los caminos a partir del mes de mayo. No la tenían los indios y pegujaleros, quienes no contaban con trojes adecuadas para guardar sus maíces y lo remitían a las trojes de la alhóndiga en los primeros meses después de levantada la cosecha, de lo que podían resultar daños como que los maíces se ponían amarillos por haber sido transportados en la humedad de los canales y luego puestos en trojes inadecuadas que afectaban su blancura. Entonces, después de que se habían vendido los maíces amarillos y el que transportaban los arrieros a precios bajos, empezaba la época de los precios altos y era el momento en que los hacendados de Chalco abrían sus trojes para enviar sus maíces blancos y, así, por los caminos de agua circulaban cientos de canoas transportando el maíz de los grandes hacendados.

29 Hay que mencionar, como señala Vera (1993: 239), que la actividad artesanal era importante en ciertos distritos como Ozumba, donde los padrones eclesiásticos muestran que hilar y tejer eran las principales ocupaciones de la población en 1793; a ellas se dedicaban el $46,07 \%$ de las personas cuya actividad se especifica en los padrones. Sin duda, de esto se beneficiaban los comerciantes y dueños de telares, como los mencionados Joseph Rubín o Juan Joseph Ramírez.

30 Van Young (1992). Para información suplementaria sobre el comercio en el mundo rural y urbano, véanse los trabajos de Liehr (1996) y Bernecker (1992: 140-190). 
Por ello, el procurador Gaspar Hurtado señala a Manuel de Rivas Cacho, quien entre 1754 y 1760 remite sus maíces a la alhóndiga en forma caprichosa: de 1754 a 1758 sólo remite 6.300 fanegas y en 1760 remite 10.500. En el quinquenio de 1754 a 1758 los precios del maíz eran bajos, y en cambió en 1760 el precio llegó a cinco pesos y medio la carga. Por ello se afirma:

la causa por que cuando remite maíz lo haze en los meses mayores, es por que en estos regularmente sube el prezio del maíz; luego don Manuel de Rivas Cacho todo su fin e yntento es vender su maíz a subido precio. ${ }^{31}$

Y para esto el control del tráfico de sus maíces por los caminos de agua era decisivo. Sólo una noche de transporte le deparaba ingresos extraordinarios. $^{32}$

Pero no sólo los grandes hacendados se benefician de esta situación, detrás de esta élite de las grandes propiedades, aparece también por los canales la gente humilde. Desde el indio pegujalero que transporta sus maíces entre noviembre y mayo, los chinamperos que envían sus hortalizas, los pescadores que envían diez u once especies de pescados que se "cosechan" en el lago, los cazadores de aves acuáticas que tenían el privilegio de cazar unas 109 especies de aves que llegaban anualmente en un promedio de cinco millones, hasta los comerciantes medios que introducen azúcares, ganado, alcoholes y diversos productos de la tierra caliente. ${ }^{33}$

31 AGN, Alhóndigas, vol. 2, exp. 1, f. 287.

32 Javier Ortiz de la Tabla (1978) en su estudio sobre el comercio entre Veracruz y España afirma que la carencia de ríos navegables en el interior para transportar las mercancías, las enormes distancias del virreinato de Nueva España, los gravámenes que pesaban sobre las ventas y todos los artículos en general y el mal estado de los caminos provocaban la carestía de los efectos europeos y los de exportación del reino, acentuándose aún más estas subidas en los años de guerra y la última década del siglo XVIII y primera del XIX. Estados Unidos contaba con ríos navegables y mejores medios de comunicación. Cuba, mucho más reducida en extensión que Nueva España, ofrecía esta misma ventaja. Ésta era la enorme ventaja de los hacendados de Chalco, incomparable en relación a otros en la Nueva España: contar con medios de comunicación navegables como en Cuba o los Estados Unidos.

33 En otro artículo hemos mencionado cómo la importancia del agua era crucial en el valle de México por lo menos hasta el siglo XIX, ya que los habitantes de los pueblos trabajaban en sus chinampas, circulaban en barcas construidas por ellos mismos, complementaban sus recursos con la recolección, la caza y la pesca en el lago; pero desafortunadamente las fuentes que nos muestran esta situación son más cualitativas que cuantitativas, por lo que medir la importancia de la econo- 
Chalco, como hemos visto, no sólo era una provincia con tierras productivas donde se cosechaban los mejores maíces del valle, lo que es necesario subrayar. La cosecha de 1759 nos muestra haciendas extraordinariamente fértiles: Zavaleta con 4.627 cargas de maíz, Retana con 3.333, El Moral con 3.033, Chiconquiahuitl con 2.333, etc. Esta fertilidad se agudiza cuando sabemos que en 1893, las haciendas más productivas de todo el estado de México, y no sólo de Chalco producen entre 800 y 6.800 cargas de maíz, y allí sólo aparece una de Chalco: El Moral con sus 4.000 cargas. $^{34}$ Entonces, estas haciendas alcanzaron un nivel de productividad en 1759 que sus pares del Porfiriato envidiarían en 1893. ¡El Porfiriato, con su ilusión de modernidad, no pudo alcanzar los niveles productivos de las haciendas maiceras de Chalco del siglo XVIII La inmensa hacienda de La Gavia, con sus 64.500 hectáreas en Toluca, apenas produjo 2.000 cargas de maíz en 1893; Enyejé, en el distrito de Ixtlahuaca con sus 12.803 hectáreas produjo lo mismo. En Chalco, en cambio, pequeñas unidades productivas produjeron, desde el siglo XVIII, grandes cantidades de granos.

Pero Chalco era también, no sólo un lugar geográfico adecuado al cultivo de la tierra, sino también a la circulación. Chalco se había convertido, por su posición de intermediaria, en la "garganta del reino", boca de entrada a la ciudad de México, que en el XVIII era la ciudad más importante de América.

En suma, al decir caminos de agua, quisimos precisar que ellos son una puerta de entrada hacia un desfile de actores y productos que nos muestran la complejidad del México central durante varios siglos. ${ }^{35}$ Aquí hemos mostrado a algunos que se benefician de la geografía de los canales navegables: por estos caminos no sólo encontramos "bandoleros", sino un crisol de productos y personajes que nos muestran que en sus puertos no sólo se embarcaban los temibles bandidos de Río Frío.

mía indígena en el comercio por vías navegables es tarea que hasta ahora no hemos podido lograr (Tortolero 1997; 2000).

34 Las haciendas más productivas son: Solís (6.800 cargas), El Moral (4.000), Cartagena (3.000), Jalpa (3.000), Enyejé (2.000), San Juan de la Cruz (2.000), La Gavia (2.000), Canaleja (1.900) y del Río (800) (Tortolero 1995: 230).

35 En otras partes de México, los ríos y canales más que una posibilidad de comunicación eran un impedimento al tráfico de mercancías y hombres como bien lo señala Calvo (1997: 47-52). Para el caso francés, véase la ejemplar investigación de Lepetit (1988). 


\section{Bibliografía}

Alzate Ramírez, José A. (1831): Gacetas de Literatura de México. [México 17891795], reimpresión en 4 vols. Puebla: Oficina del Hospital de S. Pedro, a cargo de M. Buen Abad.

- (1982): "Proyecto para el desagüe de la laguna de Tescuco, 1767". En: Zertuche Muñoz, Fernando (ed.): El territorio mexicano, vol. 3, mapa 24. México, D.F.: IMSS.

Arecheo (1771): "Informe. Pretenden los labradores de la Provincia de Chalco que se sobresea en la ejecución del auto de V. S. Iltma. de diez y ocho de diciembre del año inmediato en que mando se pague el real derecho de alcabala correspondiente al maíz y trigo que se vende fuera de los mercados o plazas publicas. México, Abril 3 de 1771" (AGI, 2.096).

Artís, Gloria (1993): "La tierra y sus dueños". En: Tortolero, pp. 195-226.

Bernecker, Walther L. (1989): Schmuggel. Illegalität und Korruption im Mexiko des 19. Jahrhunderts. Frankfurt/Main: Vervuert.

- (1992): De agiotistas y empresarios. En torno de la temprana industrialización mexicana (Siglo $X I X$ ). México, D.F.: Universidad Iberoamericana.

Calvo, Thomas (1997): Por los caminos de Nueva Galicia. Transportes y transportistas en el siglo XVII. Guadalajara, Jal.: Universidad de Guadalajara.

Coatsworth, John D. (1984): El impacto económico de los ferrocarriles en el Porfiriato. México, D.F.: Era.

- (1990): Los origenes del atraso. Nueve ensayos de historia económica de México en los siglos XVIII y XIX. México, D.F.: Alianza Editorial Mexicana.

Chevalier, François (1952): La formation des grands domaines au Mexique. Terre et société aux $X V T^{e}-X V I I^{e}$ siècles. Paris: Institut d'Ethnologie.

Durán, Juan Manuel (1983): "Los proyectos de construcción de canales en el México de la segunda mitad del siglo diecinueve". En: Relaciones, 4, pp. 96-106.

Espinosa, Gabriel (1996): El embrujo del lago. El sistema lacustre de la Cuenca de México en la cosmovisión mexica. México, D.F.: UNAM.

Flores Clair, Eduardo (2000): "Reseña sobre Clara Elena Suárez Argüello (1997)". En: <http://www.h-mexico.unam.mx> (29.08.2005).

Florescano, Enrique (1969): Precios del maiz y crisis agricolas en México, 17081810. México, D.F.: El Colegio de México.

- (2000): Breve historia de la sequía en México. $2^{\mathrm{a}}$ ed., México, D.F.: CONACULTA.

Florescano, Enrique/Pérez Gavilán, David/Sancho y Cervera, Jaime (1980): "Las sequías en México. Historia, características y efectos". En: Comercio exterior, 30, 7, pp. 747-757.

Garavaglia, Juan Carlos/Grosso, Juan Carlos (1988): Las alcabalas novohispanas (1776-1821). México, D.F.: AGN.

García Acosta, Virginia (1989): Las panaderias, sus dueños y trabajadores. Ciudad de México, siglo XVIII. México, D.F.: CIESAS. 
García Martínez, Bernardo (1992): Las carreteras de México (1892-1992). México, D.F.: SCyT.

- (1995) "Los caminos del ganado y las cercas de las haciendas. Un caso para el estudio del desarrollo de la propiedad rural en México". En: Historia y Grafia, 5, pp. 13-29.

Gerhard, Peter (1986): Geografia histórica de la Nueva España, 1519-1821. México, D.F.: UNAM.

Gibson, Charles (1967): Los Aztecas bajo el dominio español, 1519-1810. México, D.F.: Siglo XXI.

Haber, Stephen (1989): Industry and Underdevelopment. The Industrialization of Mexico, 1890-1940. Stanford, Calif.: Stanford University Press.

Hassig, Ross (1990): Comercio, tributo y transportes. La economía política del Valle de México en el siglo XVI. México, D.F.: Alianza Editorial Mexicana.

Kuntz, Sandra (1995a): Empresa extranjera y mercado interno. El Ferrocarril Central Mexicano (1880-1907). México, D.F.: El Colegio de México.

- (1995b): "Mercado interno y vinculación con el exterior. El papel de los ferrocarriles en la economía del Porfiriato". En: Historia Mexicana, 45, 1, pp. 39-66.

Lepetit, Bernard (1988): Chemins de terre et voies d'eau. Réseaux de transports et organisation de l'espace en France, 1740-1840. Paris: EHESS.

Liehr, Reinhard (1996): "Andrés Torres, comerciante y empresario de Puebla entre mercado interno y economía atlántica, 1797-1812". En: Ibero-Amerikanisches Archiv, 22, 1-2, pp. 103-130.

Martínez, Lucía (1996): "Máquinas, naturaleza y sociedad en el distrito de Chalco, Estado de México a finales del siglo XIX". En: Tortolero, pp. 253-281.

Martínez, Lucía/Tortolero, Alejandro (2000): "Les limites de la modernisation porfirienne. Chemin de fer et marché dans le bassin de México (1880-1911)". En: Cahiers des Amériques Latines, 34, 2, pp. 119-138.

Musset, Alain (1992): El agua en el valle de México, siglos XVI-XVIII. México, D.F.: Pórtico de la Ciudad de México, CEMCA.

Orozco y Berra, Manuel (1864): Memoria para la Carta Hidrográfica del valle de México. México.

Ortiz de la Tabla, Javier (1978): Comercio exterior de Veracruz, 1778-1821. Crisis de dependencia. Sevilla: EEHA.

Ortiz Hernán, Sergio (1970): Caminos y transportes en México a fines de la colonia y principios de la independencia. Su relación con el marco económico y social. Tesis de licenciatura, México, D.F.: UNAM, Facultad de Economía. (Una versión abreviada y retrabajada fue publicada por el FCE.)

Payno, Manuel (1968): Los bandidos de Rio Frío. $4^{\mathrm{a}}$ ed., México, D.F.: Porrúa.

Romano, Ruggiero (1998): Moneda, seudomonedas y circulación monetaria en las economías de México. México, D.F.: FCE.

Sierra, Carlos J. (1973): Historia de la navegación en la Ciudad de México. México, D.F.: Depto., Sectretaría de Obras y Servicios. 
Suárez Argüello, Clara (1994): Camino real y carrera larga. La arriería en la Nueva España a fines del XVIII. Tesis de doctorado, México, D.F.: UIA.

- (1997): Camino real y carrera larga. La arriería en Nueva España durante el siglo XVIII. México, D.F.: CIESAS.

Tortolero, Alejandro (1995): De la coa a la máquina de vapor. Actividad agrícola e innovación tecnológica en las haciendas mexicanas, 1880-1914. México, D.F.: Siglo XXI.

- (1997): "Les hommes et les ressources naturelles dans le bassin de Mexico. L'innovation technologique et son impact dans un milieu rural: Chalco (18901925)". En: Annales. Histoire, Sciences Sociales, 52, 5, pp. 1085-1114.

- (2000): El agua y su historia. México y sus desafios hacia el siglo XXI. México, D.F.: Siglo XXI.

- (2001): Empresarios y navegación en la cuenca de México. La importancia de los canales en los siglos XVIII y XIX. México, D.F.: UAM.

Tortolero, Alejandro (ed.) (1993): Entre lagos y volcanes. Chalco-Amecameca, pasado y presente. Zinacantepec, México, D.F.: El Colegio Mexiquense.

- (ed.) (1996): Tierra, agua y bosques. Historia y medio ambiente en el México central. México, D.F.: CEMCA.

Tutino, John (1976): Creole Mexico. Spanish Elites, Haciendas and Indian Towns, 1750-1810. Ph. D. thesis. Austin, Tex.: University of Texas Press.

Van Young, Eric (1981): Hacienda and Market in Eighteenth-Century Mexico. The Rural Economy of the Guadalajara Region, 1675-1820. Berkeley, Calif.: University of California Press.

- (1992): La crisis del orden colonial. Estructura agraria y rebeliones populares de la Nueva España, 1750-1821. México, D.F.: Alianza Editorial Mexicana.

Vera, Martha (1993): "Familias y comportamiento demográfico en Ozumba". En: Tortolero, pp. 227-264.

Yermo, Juan Antonio (1788): Informe sobre todo género de agricultura en la Nueva España. México, D.F.: Archivo General de la Nación (copia mecanografiada). 
Anexo: Dueños de tiendas y comerciantes de Chalco 1769

\begin{tabular}{ll} 
Propietario & Propiedades igualadas \\
\hline Martín Gastea & $\begin{array}{l}\text { Dos tiendas [y] una tocinería que } \\
\text { consume anual[mente] doscientos } \\
\text { veinte cerdos. } \\
\text { Comercio en [artículos de] Puebla, } \\
\text { tierra caliente y Chalco. }\end{array}$ \\
Dos tiendas. \\
Domingo de la Rúa & Una tienda. \\
Joaquín de Irurtia Sucs. & Una tienda. \\
Agustín del Huerto & Una tienda. \\
Pedro de Ocampo & Una tienda. \\
Fernando López & Comercio en casa. \\
Diego Álvarez & Dos velerías y comercio en casa. \\
Melchor Gutiérrez & Abasto de carnero. \\
Ambrosio Martínez & Repartimiento. \\
Antonio Basilio España (Ayotzingo) & Tienda y comercio. \\
José Paiba & Tienda y comercio. \\
Francisco Rubín & Comercio en casa. \\
Cristóbal Leite & Comercio en casa. \\
Cristóbal Ferras & Comercio en casa. \\
Cristóbal Medina (Tetelco) & Tienda y comercio. \\
Nicolás Regalado & Comercio en casa. \\
Manuel Ríos & Tienda y comercios. \\
Juan José de Vas[?] y Guzmán & Tienda y comercio. \\
Manuel Santander & Tienda y comerciomercio. \\
Vicente Guerrero (Tenango) & Antonio Ramírez
\end{tabular}


Propietario

José de la Peña

Tomás Quiroga (Ozumba)

Alberto Díaz

Pedro Gavira

Juan Díaz

Bernardo Ramírez

Agustín Ramos

Juan Antonio Irueta

Ramón Saldaña

Manuel de Amaro

Miguel Colón

Juan José Pavón

Antonio Medina

Luis Rodríguez (Amecameca)

Pedro Fernández

Juan José Ramírez

José Rubín

Manuel de la Canal

Juan Paulín

Manuel Ximénez

Valentín Jiménez

Juan Solano (Tlalmanalco)

\section{Propiedades igualadas}

Tienda y comercio.

Tienda y comercio.

Tienda y comercios.

Tienda y comercios.

Tienda y comercios.

Tienda y comercio.

Tienda y comercio de Puebla y tierra caliente.

Comercio de su repartido.

Tienda y comercios de Puebla y tierra caliente.

Comercio en casa.

Comercio en casa.

Tiendecita.

Tiendecita.

Repartimiento.

Tienda, comercio de tierra caliente [y] Puebla y telares para fabricar ropa en su casa.

Dos tiendas, tocinerías, telares de fabricar ropa y comercio en Puebla y tierra caliente.

Dos tiendas, telares de fabricar ropa, tocinería y comercio [en artículos] de Puebla y tierra caliente.

Tienda y comercio de Puebla y tierra caliente.

Encomendero y varios comercios cortos.

Tienda y tocinería en casa.

Tiendecita en Ayapango.

Tiendecita. 


\begin{tabular}{|c|c|}
\hline Propietario & Propiedades igualadas \\
\hline Francisco Xavier Roldán & $\begin{array}{l}\text { Tienda y comercio de tierra caliente } \\
\text { [y] Puebla y Matanza de Cerdos. }\end{array}$ \\
\hline Francisco Xavier Cacho (Ixtapalucan) & $\begin{array}{l}\text { Tienda y comercio de Puebla y } \\
\text { tierra caliente. }\end{array}$ \\
\hline Ventura de Mesa & Tienda y comercio. \\
\hline Nicolás de Orta & Tienda. \\
\hline José Campos & Comercio. \\
\hline José Carrión & Comercio en casa. \\
\hline Mariano Campos (Ayotla) & Tiendecita. \\
\hline Bonifacio López & Tienda y comercio. \\
\hline Antoni Massías & Tiendecita y comercio. \\
\hline Ambrosio López San Vicente & Tienda. \\
\hline Agustín Martínez (Chimalhuacán) & Tienda y comercio. \\
\hline Tomás de Aquino & Tienda. \\
\hline Martín del Pulgar (Tlaltongo) & Tienda. \\
\hline Gabriel de Almaraz & Tienda. \\
\hline Francisco Chavarría & $\begin{array}{l}\text { Tienda }[y] \text { comercio y algunos } \\
\text { cerdos. }\end{array}$ \\
\hline Nicolás Noverón & Comercio en casa. \\
\hline Salvador García Magdalena & Comercio en casa. \\
\hline José Godoy (Coatepec) & Tiendecita. \\
\hline Ignacio Solís (Tlapacoya) & Tiendecita y comercio. \\
\hline Dionisio Pozos & Comercio en casa. \\
\hline Repartidores según principal & Comercio. \\
\hline Lucas de Illera & $\begin{array}{l}\text { Igualado en setenta y puede dar } \\
\text { ochenta. }\end{array}$ \\
\hline \multicolumn{2}{|l|}{ Juan José Enríquez } \\
\hline \multicolumn{2}{|l|}{ José Garcés } \\
\hline \multicolumn{2}{|l|}{ Luis Rodríguez } \\
\hline José Rodríguez & \\
\hline Juan Cortés & \\
\hline
\end{tabular}


Propietario

José Ramírez

José Rodríguez

Pablo Pinto

\section{Propiedades igualadas}

Comercios en Venta de Río Frío.

Abasto de vacas [y] tres mil quinientos toros anuales.

Nota: Los nombres fueron modernizados y los apellidos dejados como se escribieron en el documento.

Fuente: Razón individual de los dueños de tiendas y comerciantes que hay en esta provincia de Chalco para lo que podrán pagar hallándome bien instruido por la experiencia que tengo de seis años que he servido a este ramo de Alcabalas de cuenta de su majestad, Chalco, septiembre 24 de 1769. AGI, Audiencia de México, 2.096 . 


\section{Rosa María Meyer Cosío}

\section{El difícil equilibrio. Tropiezos de una empresa británica con el Gobierno mexicano}

La importancia de la presencia británica durante las primeras décadas del periodo independiente puede ser analizada desde distintas perspectivas, pero es indudable que fue en el terreno económico donde se hizo más visible, a través de los fuertes capitales invertidos en diversas actividades económicas.

Una vez consumada la separación de la metrópoli, el optimismo que los criollos nacionalistas sentían por su futuro no sólo era compartido en el interior del país sino también en el extranjero. Se sabía que México tenía una enorme riqueza potencial pero, si se quería desarrollarla, debía contar con la ayuda del exterior, especialmente de la Gran Bretaña, que era el centro del sistema mundial en términos económicos y políticos. Los ingleses, además de poseer el capital y los adelantos técnicos que necesitaba el país, podrían poner un freno a los intentos españoles para reconquistar sus antiguas colonias. Por este motivo era de suma importancia para el Gobierno mexicano obtener el reconocimiento británico y atraer las inversiones de los particulares.

Por su parte los comerciantes y financieros ingleses que, desde tiempo atrás, habían comenzado a participar de manera más o menos encubierta en actividades comerciales con las colonias españolas, ${ }^{1}$ vieron la oportunidad de invertir sus capitales en las nuevas naciones latinoamericanas, así, aun antes de que hubiera un reconocimiento oficial por parte de la Gran Bretaña sobre la independencia de México, algunos comerciantes ingleses comenzaron a establecerse en el país y varias empresas mercantiles y bancarias enviaron a sus representantes, tanto para estudiar las posibilidades de inversión, como para entablar los contactos necesarios. Durante esta primera etapa, el capital británico orientó su inversión hacia tres sectores: el comercio de importación

1 Guadalupe Jiménez Codinach (1991) realiza un análisis interesante sobre la participación del Gobierno y de algunos empresarios británicos en la América española durante el comercio neutral. 
y exportación, la minería y los empréstitos al Gobierno mexicano, compitiendo en algunas ocasiones con los empresarios locales (criollos y españoles), y en otras, compartiendo con ellos inversiones y riesgos.

Con el propósito de mostrar los alcances y repercusiones de algunas de estas actividades, analizaremos a lo largo de este artículo el desempeño empresarial de una de las primeras casas comerciales británicas que se establecieron en la capital de la naciente República mexicana: la firma de Manning y Marshall, convertida posteriormente en Manning y Mackintosh. ${ }^{2}$

El interés por analizar las actividades de esta casa no radica únicamente en el hecho de que haya llegado a ser la más importante de cuantas establecieron los británicos en la ciudad de México durante la primera mitad del siglo XIX, sino que tiene que ver también con algunas características peculiares de su quehacer empresarial, sobre todo las relacionadas con las transacciones financieras efectuadas con el Gobierno mexicano, pues fueron éstas las que les permitieron obtener enormes beneficios y participar en algunos sectores económicos que permanecían bajo el control del Estado. Sin embargo, estas actividades también implicaban grandes riesgos a causa de la inestabilidad política y de la permanente escasez de recursos del erario que caracterizaron este periodo de manera muy particular. En estas circunstancias, la importancia de mantener un equilibrio adecuado entre las distintas inversiones se pone de manifiesto y la capacidad para adaptarse a los cambios continuos, sin depender demasiado de un sólo sector, puede determinar en gran medida el éxito o el fracaso en las actividades empresariales.

$\mathrm{Si}$ nos basamos en las referencias generales que existen sobre el funcionamiento de las casas británicas establecidas en esa época en el país, podemos decir que estamos frente a un caso que no puede ser considerado como un ejemplo típico, sino más bien como una excepción, sobre todo tomando en cuenta el largo periodo de su funcionamiento - casi treinta años, frente al promedio de cuatro a seis observado en la mayoría de los casos- así como la magnitud de los intereses económicos y políticos de los negocios en que se vio involucrada.

2 Un primer acercamiento a la actividad de esta empresa se encuentra en dos artículos míos (Meyer 1987; 2000). 
Para comprender mejor el contexto en el que se realizan estas actividades, sobre todo las financieras, es conveniente hacer una breve revisión de la situación del país y de la actitud asumida por los diversos Gobiernos en relación a un aspecto que fue de la mayor trascendencia y que influyó de manera decisiva en la historia nacional de ese periodo: la especulación con los llamados "papeles de la deuda pública".

A lo largo de los primeros cincuenta años de vida independiente los problemas financieros de México son de tal magnitud que no existe prácticamente ninguna obra sobre esta etapa de su historia que no se refiera a ellos. La mayoría de los autores coinciden en señalar que la continua falta de recursos del erario fue uno de los problemas más difíciles que tuvieron que enfrentar los distintos Gobiernos, independientemente de su postura política, y que la imperiosa necesidad de dinero los obligó a recurrir a los préstamos de los particulares, en condiciones cada vez más desfavorables.

Estos problemas financieros del Gobierno central habían comenzado desde finales de la época colonial, pero se fueron agravando en la etapa independiente a causa de la desorganización hacendaría, de la disminución o desaparición de varios de los ramos de donde provenían los ingresos del Gobierno novohispano y del aumento del gasto público ocasionado por la guerra y por los continuos disturbios políticos que se sucedieron a lo largo de este periodo y que obligaron al Gobierno a destinar buena parte de sus recursos a la pacificación de diversas regiones y a la defensa del país frente a las agresiones del exterior.

Para poder cubrir los gastos más urgentes -y en algunas ocasiones hasta los gastos ordinarios de la administración-, el Gobierno tuvo que recurrir, cada vez con mayor frecuencia, a los préstamos contratados con las grandes casas comerciales a través de diversos mecanismos. Siendo los ingresos aduanales la fuente principal de recursos de la hacienda pública, fue en este sector donde los comerciantes comenzaron a actuar, negociando con el Gobierno el anticipo de los ingresos del año siguiente mediante la compra de órdenes sobre las aduanas, ofreciendo a cambio una parte del pago en efectivo y otra en papeles de la deuda interior.

Debido a que el Gobierno mexicano había reconocido como propia toda la deuda contraída por la administración virreinal, fueron 
estos créditos, junto con los provenientes de préstamos voluntarios o forzosos, de confiscaciones, y de los vales que el siempre Gobierno daba a sus empleados a cuenta de sus sueldos, los que en ese momento formaban la deuda interior. Estos créditos, conocidos como "papeles de la deuda pública", se encontraban en su mayoría en poder de las casas comerciales, pero también se conseguían en el mercado a un precio que fluctuaba entre el 5 y el $30 \%$ de su valor, dependiendo de la clase a la que pertenecieran.

El hecho de que el Gobierno negociara sus préstamos aceptando una determinada proporción de dichos créditos a su valor nominal, marcó el inicio de una fuerte especulación con este tipo de papeles, pues si bien una parte de la ganancia obtenida por las casas contratistas dependía de la tasa de interés que se impusiera en los contratos, la otra estaba basada en la cantidad de créditos que se lograran introducir como efectivo en cada negocio y del precio al que se consiguieran estos papeles en el mercado.

En la medida en que el Gobierno pactaba nuevos préstamos adquiría mayores obligaciones con sus acreedores y comprometía cada vez más sus ingresos futuros. Como era imposible hacer frente a todos los compromisos, se tenían que hacer nuevos arreglos con los prestamistas y el retraso en el pago de los dividendos ocasionó que muchos de ellos tuvieran que vender sus créditos a otras firmas comerciales que, por su mayor capacidad económica, estaban en posibilidad de esperar a que el Gobierno les pagara o de emplear esos créditos para hacer nuevos negocios en condiciones más ventajosas.

Además, esta incapacidad del Gobierno para cumplir con sus compromisos financieros, aunada a la necesidad de nuevos recursos y a la debilidad política de los diversos grupos que alternativamente asumían el poder, trajeron como consecuencia que con el tiempo se otorgara a los particulares, especialmente a los principales acreedores, una serie de concesiones que les permitieron desempeñar actividades que normalmente se consideraban privativas del Estado, tales como el monopolio de la producción y venta del tabaco, la administración de las casas de moneda, la explotación de las salinas, el deslinde de terrenos baldíos, la construcción y mejoramiento de caminos, de muelles y varios más.

En fin, existía toda una gama de posibilidades para quienes contaran con el capital suficiente, tanto para entrar en este tipo de negocios 
especulativos con el Gobierno, como para explotar adecuadamente las concesiones que éste se veía forzado a otorgar.

\section{Los inicios de la empresa}

Es en este contexto donde va a desarrollar sus actividades la firma británica que se establece en México, en 1824, con el nombre de Manning y Marshall. Sus socios originales, Roberto Manning y Guillermo Marshall, fundan una casa comercial en la capital con una sucursal en Veracruz y se dedican a emprender actividades tanto en el comercio de importación como en el comercio interno, estas últimas relacionadas principalmente con la compra-venta y distribución del tabaco. Además, como representantes de la firma Barclay, Herring, Richardson y Cía., que es la encargada de negociar con el Gobierno uno de los dos empréstitos que dan origen a la deuda externa, son quienes se ocupan de realizar las transferencias de fondos y atender todos los asuntos relacionados con este empréstito. ${ }^{3}$ Cuando México comienza a fallar en sus obligaciones para con los tenedores de bonos ingleses, éstos nombran a Roberto Manning para que los represente en las negociaciones con el Gobierno mexicano (Bazant 1968: 47).

Al ser el comercio de importación el centro de sus actividades, empiezan a aprovechar los vínculos establecidos con el Gobierno para hacerle adelantos sobre los derechos que van a causar las mercancías que esperan recibir por los puertos de Veracruz y Tampico, pagando entre el 50 y el $60 \%$ en papeles de la deuda pública y el resto en efectivo. Entre los años de 1828 y 1829 encontramos registradas varias operaciones de este tipo, cuyo monto asciende a la cantidad de $\$ 205.850$ (Zavala 1829). Esto no significa necesariamente que sus actividades de importación hayan generado derechos por toda esta suma, pues en varias ocasiones se vendían estos permisos a otros comerciantes y de esta manera se obtenía una ganancia adicional.

Otra práctica que el Gobierno había comenzado a establecer desde 1825, era el arrendamiento de las casas de moneda a los particulares, medida que benefició enormemente a los arrendatarios ya que, en opinión de los especialistas:

3 Archivo General de la Nación (en adelante AGN), Ramo Consulado, vol. 20, 1824. 
Las utilidades que obtuvieron los particulares que rentaban los establecimientos de amonedación y apartado llegaron a ser fabulosas, no sólo por ser un monopolio legitimado altamente redituable, sino por la especulación que hicieron con la disponibilidad de metales y por su situación privilegiada frente a los productores de metales preciosos (Velasco et al. 1988: 140).

Al convertirse en representante de la Compañía Minera Anglo Mexicana (Anglo-Mexican Mining Company), en febrero de 1825, la casa de Manning y Marshall comienza a incursionar en este campo administrando la casa de moneda de Guanajuato.

En 1830, las concesiones que el Gobierno comienza a otorgar para allegarse recursos les brindan la oportunidad de participar en la primera compañía que se forma para arrendar el monopolio gubernamental de la producción y venta del tabaco, en la cual los comerciantes, como socios capitalistas, debían introducir un fondo de tres millones de pesos a cambio de la mitad de las utilidades que produjera la compañía, que además era administrada por ellos mismos. ${ }^{4}$

Sus contactos con inversionistas británicos están relacionados, en la mayoría de los casos, a actividades comerciales y mineras, pero no se restringen sólo a estos campos, puesto que, como ya hemos señalado, también eran representantes de los tenedores de bonos ingleses y, por lo tanto, eran los encargados de recibir el porcentaje de los derechos aduanales que el Gobierno dedicaba para ir amortizando esta deuda.

La participación de la firma en todos estos sectores era importante, sin embargo, sus intereses estaban dirigidos principalmente al comercio y a las actividades financieras. Manning y Marshall, como todas las grandes casas comerciales, abría líneas de crédito, llamadas cuentas corrientes, a los comerciantes del interior y también del extranjero, quienes las utilizaban girando libranzas, que eran como órdenes de pago emitidas por un comerciante a favor de otro y a cargo de estas casas, las cuales cobraban entre el 6 y el $15 \%$ de comisión por realizar este tipo de operaciones. También negociaban letras de cambio, que aceptaban con algún descuento; transferían recursos de un sitio a otro, tanto dentro del país como en el exterior, principalmente a Inglaterra y

4 Archivo de Notarías de la Ciudad de México (en adelante ANCM), notario Francisco Madariaga (1831, f. 105). 
Estados Unidos y llevaban a cabo conversiones de moneda y venta de pesos fuertes de plata en el extranjero.

La transferencia de recursos de un lugar a otro, tanto al interior del país como en el extranjero, fue un renglón en que la firma tuvo una participación importante. Las líneas de crédito que tenía establecidas en Inglaterra con la casa Baring Brothers y con el Banco Colonial (Colonial Bank) le permitían vender, a cambio de pesos mexicanos, letras de cambio que serían pagadas en Londres en libras esterlinas. La ganancia que obtenían en estas operaciones estaba determinada por el tipo de cambio al que vendieran las letras, aunque en las referencias que encontramos se señala normalmente el cambio de $45 \frac{1}{2}$ a $45 \frac{1}{4}$ peniques por peso, ${ }^{5}$ existían diversos factores que hacían variar esta proporción. Uno de ellos era la competencia, pues en ocasiones había varias casas que querían girar y naturalmente tenía más oportunidades quien ofreciera un precio mayor.

El negocio no era tan sencillo, porque para calcular las ganancias se debía tener en cuenta el precio fijado de antemano con la banca que debía hacer los pagos en Londres. ${ }^{6}$ También influía la demanda que hubiera de libranzas y el momento en que éstas se compraran, pues como el paquete inglés salía normalmente cada mes, entre más se acercara la fecha de la salida era más difícil competir con las casas que desde un principio habían ofrecido un mejor cambio.

El panorama se venía a complicar con la presencia del comisario inglés, que era un empleado del Gobierno británico establecido en los puertos para comprar plata mexicana con libranzas pagaderas en Londres en libras esterlinas (Walker 1991: 149). Sin embargo, según algunos testimonios de la época, Manning y Marshall podían competir con

5 Archivo de Carlos Martínez del Río Fernández (en adelante ACMRF), cartas de Pedro Ansoátegui a Gregorio José Martínez del Río, México, 16 de noviembre de 1839 y 29 de agosto de 1840.

6 En el caso del Banco Colonial, el precio que tenía acordado con Manning y Mackintosh era de $48 \frac{1}{2}$ peniques por peso. Tomando en cuenta que una libra equivalía a 240 peniques, podemos calcular que si ellos vendían en México las libras a $451 / 2$, o sean $\$ 5,27$, mientras que en Londres las pagaban a $\$ 4,94$, la diferencia a su favor era de e 33 por libra, lo que representaba una ganancia del $6,26 \%$. ANCM, notario Francisco Madariaga (1850, f. 609). 
él en lo referente al tipo de cambio y a la cantidad de libranzas que se giraban por cada paquete. ${ }^{\text {. }}$

Como ellos normalmente giraban las libranzas para ser pagadas en un plazo de 30 días, mientras que el Banco Colonial les concedía un periodo de tres meses para cubrir las cantidades que iban girando, esto les permitía acumular grandes sumas de efectivo que utilizaban en otro tipo de operaciones, también a corto plazo, que les proporcionaban una utilidad adicional.

En lo que se refiere a las transferencias en el interior del país, la mayoría de los comerciantes acostumbraba a hacerlas por medio de letras de cambio, en muchas de las cuales ya venía incluido el descuento por el menor valor que tenía el dinero en algunos sitios, así como la comisión que cobraban las casas que se encargaban de hacerlas efectivas. Sin embargo, la empresa de Manning y Marshall se dedicaba a este tipo de transacciones en una escala mucho mayor $\mathrm{y}$, según la información proporcionada por uno de los socios de la casa comercial Martínez del Río Hermanos, para mediados de 1840 controlaba casi todas las operaciones importantes.

Las sumas principales que hoy hay sobre el interior son las del Tabaco y Fresnillo y éstas las tienen tomadas Manning y Marshall, las de Zacatecas a $2 \%$, Guadalajara a $2 \frac{1}{2} \%$ de descuento y de los otros puntos en proporción, estas sumas las reciben sus agentes en fin de cada mes en aquellos lugares y las pagan aquí el 18 del siguiente mes. De cuando en cuando se presentan algunas otras partidas regulares a mejor cambio, que por lo regular las toman los mismos. ${ }^{8}$

Ya dentro de la actividad crediticia, aunque la casa otorgaba préstamos a particulares, se puede apreciar, por el monto y la frecuencia de los mismos, que este tipo de inversión no le resultaba muy atractiva, seguramente porque requería demasiado tiempo para el reembolso del capital, así que este rubro era controlado principalmente por algunas casas españolas y mexicanas. ${ }^{9}$ La gran frecuencia con que la encon-

7 ACMRF, carta de Pedro Ansoátegui a Gregorio José Martínez del Río, México, 11 de noviembre de 1839 .

8 ACMRF, carta de Pedro Ansoátegui a Gregorio José Martínez del Río, México, 29 de agosto de 1840.

9 La información referente a la actividad de la empresa como prestamista a particulares y la importancia del papel que desempeñaba en este sector, en comparación con otras firmas, se encuentra en mi artículo "Los empresarios y el crédito en el México Independiente" (Meyer 1999). Desde luego estas observaciones están ba- 
tramos, como acreedora de otros comerciantes, se debe más bien a las cuentas de comercio que seguían con ella y no al dinero proporcionado en efectivo. En la serie de quiebras de las pequeñas y medianas casas comerciales detectada a partir de 1840, Manning y Marshall aparecen con mucha frecuencia entre los acreedores.

El hecho de representar a diversas empresas británicas con intereses en el país, como la Compañía Unida de Minas Mejicana, la Compañía Anglo Mexicana y la importante firma de Baring Brothers, ${ }^{10}$ así como a los tenedores de bonos ingleses, le daba acceso a una gran cantidad de dinero efectivo, lo que la colocaba en una magnífica posición para realizar todo tipo de actividades especulativas con el Gobierno.

Desde luego, la casa supo sacar provecho de esta situación interviniendo, como ya hemos visto, en varios negocios de este tipo. Sin embargo, por lo que podemos apreciar, hasta este momento su actitud era más bien cautelosa y prefirió no involucrarse en negocios que implicaran demasiado riesgo.

\section{El cambio de los socios}

Una nueva etapa en las actividades de la casa comienza a partir de 1834, cuando Ewen Clark Mackintosh, quien había ingresado como dependiente a fines de la década anterior, aparece como socio de Guillermo Marshall y encargado de todos los negocios de la empresa en ausencia de éste. ${ }^{11}$ La muerte inesperada de Manning y el regreso de Marshall a Inglaterra marcan un cambio importante en las prácticas empresariales de la casa, ya que Mackintosh decide ampliar las actividades de la casa hacia otros campos, especialmente los relacionados con los negocios con el Gobierno. También extiende aún más sus relaciones comerciales y su influencia en el ámbito mercantil aumenta al ser nombrado cónsul británico en la ciudad de México en 1839 (Tenenbaum 1979: 321).

sadas en las evidencias notariales, pero es probable que hayan otorgado muchos préstamos más, cuyos contratos se realizaron por medio de agentes de negocios y de los cuales no tenemos noticia.

10 Algunas referencias a la actividad de la firma como representante de Baring Brothers se encuentran en Tenenbaum (1979), Platt (1982) y Liehr (1983).

11 ANCM, notario Francisco Calapis (1834, f. 829) y notario Francisco Madariaga (1835, f. 216v.). 
Para esta época Mackintosh ya había contraído matrimonio con una mexicana, Teresa Villanueva, y ambos toman posesión de la casa que había pertenecido a Roberto Manning y Guillermo Marshall, conocida como "el palacio de Capuchinas"12 probablemente en alusión al lujo que ostentaba dicha residencia, totalmente amueblada al estilo inglés. En este sentido, Mackintosh adopta una actitud distinta a la de la mayoría de sus coterráneos, pues para esa época no se conocen muchos casos de ingleses casados con mexicanas. De cualquier forma, este matrimonio le brinda la oportunidad de integrarse más fácilmente a los altos círculos de la sociedad mexicana, además de que puede interpretarse como una muestra de su intención de permanecer en el país por un largo tiempo, tal vez, definitivamente.

Desde luego, sabe aprovechar muy bien la influencia que le proporciona su nacionalidad británica y hace uso de ella en diversas ocasiones, incluso antes de su nombramiento consular, como se puede observar por una carta dirigida en 1838 a José María Bocanegra. ${ }^{13}$ En ella le pide que intervenga para resolver, cuanto antes, una demanda que tiene entablada contra un Sr. Marañón, a causa de la posesión de una azotehuela

[...] porque ya viene siendo un escándalo para los tribunales, y especialmente en una época cuando los franceses están reclamando la mala administración de la justicia en México. Si se publicase este caso aquí [Londres], tendría un efecto muy contrario a los mexicanos. ${ }^{14}$

Como se puede observar, su actitud es bastante arrogante -lo cual resulta ser una queja constante en su contra- pues no solamente solicita la intervención de un importante político mexicano para un asunto de muy poca trascendencia, sino que, además, amenaza claramente con denunciar la deficiente administración de la justicia mexicana,

12 ACMRF, carta de José Pablo Martínez del Río a Gregorio José Martínez del Río, México, 24 de mayo de 1839.

13 José María Bocanegra fue varias veces ministro de Estado, incluso llegó a ocupar la presidencia de la República por unos días, en diciembre de 1829, tras la destitución de Vicente Guerrero. Aunque con diversas interrupciones, entre los años de 1829 y 1844 se encargó en varias ocasiones del ministerio de Hacienda, pero fue en el de Relaciones Interiores y Exteriores donde permaneció por periodos más prolongados.

14 Benson Latin American Collection. University of Texas at Austin (en adelante BLAC), Manning and Mackintosh Papers, Serie 1, Correspondencia, carta de Ewen C. Mackintosh a José María Bocanegra, Londres, 4 de octubre de 1838. 
precisamente en un momento en el que el país está atravesando por una seria crisis en sus relaciones internacionales a causa de la invasión francesa.

Este conflicto bélico complica aún más la ya de por sí difícil situación de las finanzas públicas, pues además de los gastos extraordinarios que se deben hacer para defender el territorio, el bloqueo de los puertos priva temporalmente al Gobierno de su principal fuente de recursos: los ingresos aduanales. Esta situación brinda a muchas casas comerciales la oportunidad de realizar préstamos en condiciones muy desfavorables para el erario y representa uno de los momentos culminantes de las operaciones especulativas con el Gobierno, conocidas en la historiografía como agiotismo. Sin embargo, a medida que crecen los compromisos con los acreedores, los problemas financieros se agravan y comienza un círculo vicioso en el que el Gobierno debe pedir ciertos sacrificios a sus prestamistas a cambio de los beneficios que antes habían obtenido. Hasta que llega un momento en el que los negocios con el Gobierno comienzan a resultar menos atractivos para la mayoría de los prestamistas, pues los dividendos se vuelven más escasos y la posibilidad del reintegro más remota, reduciéndose notablemente el número de quienes deciden seguir participando en este tipo de operaciones especulativas, sobre todo cuando implican un riesgo demasiado grande.

Si bien la hipoteca de los ingresos aduanales ya no proporciona suficiente seguridad para quienes todavía están dispuestos a arriesgarse, el Gobierno sigue ofreciendo magníficas posibilidades de ganancia a sus acreedores favoritos a través de diversas concesiones. Entre 1841 y 1842 la firma de Manning y Marshall consigue renovar el contrato de arrendamiento de la casa de moneda de Guanajuato, obtiene además los de Zacatecas, Guadalupe y Calvo y Culiacán (1843) y finalmente, en 1847, el de la más importante, la casa de moneda de la ciudad de México (Velasco et al. 1988: 141-146).

El otorgamiento de algunos de estos contratos, especialmente los de Guanajuato y Zacatecas, enfrenta una fuerte oposición en sus respectivas regiones $\mathrm{y}$, en 1845, los Congresos locales de estos departamentos piden su anulación por parte del Congreso central. Sin embargo, para contrarrestar estos ataques, Mackintosh contaba con dos armas poderosas: el apoyo diplomático y la disponibilidad de dinero en 
efectivo. Respecto al primero nos informa José Pablo Martínez del Río en una de sus cartas

[...] Actualmente parece que Mr. Bankhead [el ministro británico] quiere pelearse con el Gobierno en favor y por motivo del negocio de la casa de Moneda de Zacatecas, es decir, de Mackintosh. Pretende dicho Ministro que este negocio no entre a revisión a lo cual es difícil que acceda el Gobierno, porque la ley le obliga a mandar revisar todos los actos de la Administración Provisional. Veremos en qué paran los toros [...]. ${ }^{15}$

Aunque finalmente los contratos pasan a revisión, ambos son ratificados el 27 de diciembre con los mismos precios de arrendamiento de las contratas originales y mediante un préstamo de $\$ 200.000$ que el Gobierno recibe a cuenta de las utilidades de los dos establecimientos (Romero 1870: 394).

De esta manera, entre 1847 y 1849 , Mackintosh llegó a controlar, según las estimaciones de algunos especialistas (Velasco et al. 1988: 143 ) "más de $80 \%$ de la plata y casi $90 \%$ del oro acuñados" en este periodo. Lo cual le permitió, en opinión de los mismos autores, utilizar esta enorme disponibilidad de plata amonedada para ejercer actividades especulativas con el Gobierno, además de que la simple operación legal de las casas de moneda que estaban en su poder le proporcionó "ganancias superiores a los 200.000 pesos anuales".

La red de contactos y empleados que la firma establece a lo largo del país, le permite en ocasiones realizar labores propias de las oficinas gubernamentales, como es el caso de la recaudación de un préstamo forzoso decretado en 1843, en el cual el Gobierno encarga a la casa de recibir en todas las capitales de los departamentos, incluso en México, las cantidades que se deben entregar a cuenta de dicho préstamo (Romero 1870: 930). Al año siguiente, la Junta de Fomento y Administrativa de Minería celebra un contrato con la firma, que ya para entonces había cambiado su nombre por el de Manning y Mackintosh, para que se encargue de recaudar todos los derechos de minería pertenecientes al fondo dotal de dicha Junta en cualquier lugar que se causasen, a cambio de lo cual se le pagaría una comisión del $4 \%$ sobre todo lo recaudado. ${ }^{16}$ Este tipo de contratos muestran que los mecanismos de recaudación que poseían estas grandes casas comerciales

15 ACMRF, carta de José Pablo Martínez del Río a Gregorio José Martínez del Río, México, 28 de septiembre de 1845.

16 ANCM, notario Manuel García Romero (1844, f. 138). 
eran, en ocasiones, más eficientes que los del propio Gobierno, pues como los empleados públicos casi nunca estaban pagados, descuidaban sus obligaciones y eran muy susceptibles a la corrupción.

\section{La deuda externa}

Ya para 1845 la influencia que ejercía Mackintosh en el ámbito comercial y financiero, así como los beneficios que había obtenido a través de las concesiones otorgadas por el Gobierno, lo animan a incursionar en proyectos más ambiciosos, como es el caso de la conversión de la deuda externa. ${ }^{17}$ Este aspecto lo analizaremos con algún detalle, debido a la importancia que tuvo en el comportamiento posterior de la firma.

Esta deuda, que provenía de los dos empréstitos obtenidos en Inglaterra entre 1824 y 1825 , había comprometido al Gobierno a destinar periódicamente una determinada cantidad de ingresos para amortizar tanto el capital como los intereses que se generaran. Dicha cantidad debía ser entregada a los tenedores de bonos en Inglaterra, por medio de sus agentes, al término de cada uno de los plazos convenidos. Pero, a partir de 1827 , la falta de recursos del erario impide que el Gobierno pueda cumplir oportunamente sus compromisos con los tenedores de bonos, quienes naturalmente comienzan a dirigirle una serie de protestas a través de sus representantes en México, o sea, la casa de Manning y Marshall.

A medida que la falta de recursos se agudiza, el Gobierno se ve imposibilitado no sólo para amortizar la deuda sino aun de pagar los intereses acumulados. Frente a la presión ejercida por los acreedores y en un intento por recuperar el crédito del país en el extranjero, el Gobierno se ve obligado en varias ocasiones a renegociar esta deuda por medio de la capitalización de una parte de los intereses vencidos, lo que aumenta considerablemente el monto del adeudo original.

Con el tiempo, estas operaciones se convierten también en un motivo de especulación para las casas financieras encargadas de llevarlas a cabo. El ejemplo más notorio es el de la conversión iniciada en 1837 a través de la firma mexicana de Francisco de Lizardi y Cía., en la

17 Las diversas operaciones destinadas a renegociar la deuda externa son designadas en esta época con el nombre de conversión o consolidación y es en ese sentido que utilizaremos ambos términos a lo largo del trabajo. 
cual se efectuaron una serie de operaciones fraudulentas, a partir de 1839, con el apoyo del general Santa Anna. Según Jan Bazant (1968: 59-61), Lizardi cobró en realidad casi el 10\% de comisión, en vez del $2 \frac{1}{2} \%$ acordado, y obtuvo por esta operación una ganancia de más de un millón de pesos. ${ }^{18}$

Este desempeño poco escrupuloso por parte de Lizardi causó disgusto y preocupación en Londres y el malestar fue en aumento cuando, a mediados de 1845, la administración de Santa Anna comenzó a fallar en el cumplimiento de los compromisos adquiridos y puso nuevamente en entredicho el crédito de la República. Así que el Gobierno surgido tras su derrocamiento en diciembre de 1844, comenzó a tomar cartas en el asunto de la deuda, retiró a Lizardi de su puesto y nombró a John Schneider y Cía. de Londres como sus nuevos agentes ante los tenedores de bonos, en abril de 1845 .

Frente a la actitud cada vez más amenazante de los Estados Unidos, el Gobierno mexicano estaba profundamente interesado en obtener el apoyo de la Gran Bretaña, así que ante la inminencia de la guerra y la necesidad de consolidar el crédito del país en el exterior, el general José Joaquín de Herrera decidió entrar en nuevas negociaciones con los tenedores de bonos en Londres y autorizó al ministro de Hacienda, Luis de la Rosa, a iniciar los convenios necesarios para cumplir con este propósito.

Seguramente las enormes ganancias obtenidas por Lizardi despertaron en Mackintosh el deseo de incursionar en alguna operación similar y la oportunidad se presentó justamente en el momento en que el cónsul se encontraba en una posición inmejorable para intentarlo. Por un lado era el representante de los tenedores de bonos en México, contaba además con todo el apoyo diplomático de la legación británica y con los recursos financieros que le proporcionaban sus negocios en el país y sus relaciones con importantes bancos de la Gran Bretaña, las cuales harían menos costosas y complicadas las transferencias de fondos y, finalmente, contaba para esta empresa con el apoyo y las relaciones del prestamista mexicano más importante de la época: Manuel Escandón.

18 La mayoría de los autores que se han ocupado de este asunto coinciden en señalar que las emisiones de bonos fraudulentas hechas por Lizardi causaron un grave perjuicio al erario, además de aumentar el descrédito del Gobierno frente a los tenedores de bonos. 
Así que, sin pérdida de tiempo, la casa de Manning y Mackintosh hizo una propuesta que fue inmediatamente aceptada por el Gobierno y que se formalizó el 29 de abril de 1845. En ella se contemplaba la creación, en Londres, de un nuevo fondo consolidado por valor de veinte millones de pesos, que ganaría un $5 \%$ de interés anual y tendría como hipoteca especial la renta del tabaco. A cambio de la compra de este nuevo fondo, en el que no estaban incluidos todos los bonos que formaban la deuda, sino solamente los llamados diferidos y las debenturas, Mackintosh ofrecía cinco millones de pesos en bonos del $26 \%$ y dos millones de pesos en efectivo, pagaderos a plazos (Payno 1862: 12-13).

La propuesta resultaba atractiva para ambas partes, pues además de ofrecer varias ventajas al erario, brindaba a Mackintosh la oportunidad de introducir, a su valor nominal, cinco millones de pesos en créditos de la deuda interior. Además, la hipoteca especial de la renta del tabaco le permitiría tener control sobre un ramo en el que, tanto él como Escandón, habían incursionado con anterioridad y en el cual tenían intereses importantes y grandes expectativas (Walker 1991: 248-270).

Sin embargo, los tenedores de bonos en Londres se negaron a aceptar las condiciones contenidas en esta propuesta, haciéndola fracasar, por lo que debió ser modificada en varias ocasiones. Como una explicación pormenorizada de las complicadas negociaciones que se tuvieron que realizar en este sentido rebasaría los objetivos del presente artículo, considero que la breve descripción que se ofrece en los anexos 1 y 2 sobre las condiciones de las distintas propuestas, lo que Mackintosh esperaba obtener en cada caso y las razones por las que no se pudieron llevar a cabo, resultará de utilidad para comprender mejor la complejidad de este asunto y el papel que desempeñó la firma en el mismo. ${ }^{19}$

De acuerdo con la información contenida en el anexo 1, se puede observar que las tres primeras propuestas fracasaron a causa de falta de previsión por parte de Manning y Mackintosh y del Gobierno

19 Una explicación bastante detallada sobre las diversas propuestas y las negociaciones que se llevaron a cabo para realizar esta conversión se encuentra en Carba110 (1998). 
mexicano respecto a las expectativas de los tenedores de bonos en Londres.

$\mathrm{Al}$ analizar con detenimiento el modo en que se desarrollaron los acontecimientos, resulta evidente, como señala Carballo (1998: 41), que uno de los problemas principales consistió en que no se incluyeron en el plan original los bonos activos ni los intereses vencidos.

¿Por qué decidieron convertir sólo una parte de la deuda y no se les ocurrió proponer un plan que la contemplara en su totalidad?

Una posible explicación es que tanto los bonos diferidos como las debenturas tenían un valor mucho más bajo en el mercado. De acuerdo con la conversión de 1837, se habían emitido dos tipos de bonos: los activos que ganarían un interés del $5 \%$ anual y los diferidos, que no causarían ningún tipo de interés en un plazo de diez años, pero que se podían utilizar, si así lo deseaban sus dueños, en la adquisición de terrenos baldíos en el norte del país. Como señala Bazant (1968: 5254 ), este proyecto, que pretendía combinar la colonización con la amortización de la deuda, fue un rotundo fracaso y los poseedores de los bonos prefirieron dejar de percibir los intereses a arriesgarse en una empresa que no ofrecía muchas garantías de éxito. De cualquier manera, los conflictos con Francia y posteriormente las luchas internas, impidieron al Gobierno pagar los dividendos ofrecidos, así que en 1842 se emitieron nuevos títulos, llamados debenturas, con el propósito de capitalizar los intereses atrasados. Los nuevos bonos no causaban réditos y serían amortizados sólo si existían los fondos suficientes en poder de los agentes financieros del Gobierno mexicano, así que su valor real en el mercado era mucho más bajo que el de los demás bonos.

Un año antes de que se iniciara la nueva conversión, el valor real de los bonos activos en Londres era, según las estimaciones de Bazant (1968: 60), del 35\%, mientras que el de los diferidos era del 14\% y aunque no existen datos sobre las debenturas su valor debía ser menor, así que desde esta perspectiva resulta razonable que Mackintosh propusiera un plan para amortizar solamente los papeles que pudiera obtener a un bajo precio y de esta manera aumentar sus ganancias.

Este razonamiento también explicaría el hecho de que en la primer propuesta ni siquiera se le adjudicara un valor fijo a los bonos que se pretendía convertir, ni se declarara la obligatoriedad de los tenedores de incluir sus bonos en la nueva conversión. De acuerdo a las eviden- 
cias, esta propuesta fue redactada sin consultar siquiera al agente del Gobierno mexicano en Londres, puesto que es el mismo Schneider quien, al conocer su contenido, señala al ministro plenipotenciario de México en esa ciudad, Tomás Murphy, que era un error haberse comprometido con el Gobierno a cambiar todos los bonos diferidos y las debenturas por los bonos del nuevo fondo, pues no existía ninguna seguridad de que todos los tenedores quisieran venderles sus bonos y tampoco se podía calcular con exactitud el precio que se tendría que pagar por ellos. (Carballo 1998: 34).

Aunque la firma estaba bien enterada de que los bonos mexicanos en Londres se encontraban muy devaluados respecto al año anterior, a causa del retraso en el pago de los dividendos, era lógico suponer que la noticia de que se pretendía hacer una conversión con este tipo de papeles haría que su valor se incrementara rápidamente. Al analizar las condiciones en que se hace la segunda propuesta, en las que el Gobierno tiene que aumentar $£ 200.000$ al fondo de consolidación para fijar el cambio de los bonos al $40 \%$, podemos inferir que en un principio habían calculado comprarlos a un precio mucho menor.

Si bien es cierto que a partir de esta propuesta se observa que la casa presta mayor atención en definir claramente los aspectos relacionados con los costos de la operación, lo que le permite calcular de manera más precisa las ganancias, no ocurre lo mismo respecto a las condiciones que tienen que ver con los tenedores de bonos. La intención de éstos de no aprobar ningún acuerdo hasta que se obtuviera el compromiso de capitalizar los intereses atrasados desde 1844, debía haber sido prevista, puesto que la firma, en su calidad de agente de los tenedores durante tantos años, difícilmente podía pensar que renunciarían a reclamar lo que se les adeudaba sin entablar antes algún tipo de negociación.

Ante el fracaso del segundo intento, Schneider tiene que intervenir nuevamente y aconsejar a Murphy la conveniencia de tener una reunión con todos los tenedores de bonos antes de hacer una nueva propuesta. Sin embargo, la casa contratante no parece muy dispuesta a continuar con las negociaciones y pide al Gobierno, al igual que lo había hecho en la ocasión anterior, la devolución de los \$500.000 que le había adelantado por el convenio original. Al parecer, es la falta de recursos del Gobierno y la imposibilidad de conseguir la devolución de la suma anticipada, lo que les obliga a seguir adelante y presentar la 
tercera propuesta en la que, a pesar de aumentarse el valor del fondo consolidado, ellos reducen su ofrecimiento de efectivo a $\$ 1.600 .000$.

En este tercer intento se vuelve a poner de manifiesto la falta de experiencia de los negociadores mexicanos, el consejo de Schneider sobre una reunión previa con los tenedores de bonos no es escuchado y la propuesta corre la misma suerte que las anteriores. A estas alturas el negocio se presenta lo suficientemente complicado como para requerir la presencia de Escandón, quien se traslada a Inglaterra para encargarse personalmente de las negociaciones. Por su parte, Murphy cuenta con la autorización del Gobierno para remover cualquier obstáculo que se presente, así que autoriza a Schneider para negociar con los tenedores de bonos (Dublán 1888: 94), quienes le solicitan que los bonos activos también sean contemplados en la reunión que se va a efectuar a instancias del Comité de Tenedores de Bonos. Finalmente, los tres se reúnen con el vicepresidente del Comité de Bonos Hispanoamericanos, J. D. Powles, para discutir la situación y es hasta este momento cuando, al parecer, todos los involucrados se dan cuenta de que lo que desean los tenedores es una conversión equitativa para todos los tipos de bonos (Carballo 1998: 41).

Es como resultado de esta discusión que surge la propuesta presentada por Murphy el 18 de mayo de 1846, durante la reunión convocada por el Comité de Tenedores de Bonos, la cual es finalmente aprobada.

Aunque oficialmente es Murphy el autor de esta propuesta, puesto que en su carácter de ministro plenipotenciario era quien contaba con la autorización del Gobierno mexicano para hacerla, es evidente que en su elaboración participaron también Schneider, Powles y Escandón. Sin embargo, a juzgar por el contenido de una carta enviada por este último a Mackintosh, fue su participación la que realmente determinó el éxito de las negociaciones, pues comenta:

Sólo diré a V. de paso, que esté muy persuadido, que nada, nada se habría hecho sin el sacrificio mío de haberme resuelto a dejar México, abandonándolo todo por ahí, para traer un asunto a ésta, que su conclusión, en medio de las circunstancias actuales, parece ser un sueño. ${ }^{20}$

20 BLAC, Manning and Mackintosh Papers, Serie 1, Correspondencia, carta de Manuel Escandón a Ewen C. Mackintosh, Londres, 28 de junio de 1846. 
Si bien es cierto que estas declaraciones fueron hechas con el propósito evidente de impresionar a Mackintosh, no estaban tan alejadas de la realidad, pues a lo largo de la carta se puede apreciar que la participación de Escandón y los arreglos que llevó a cabo con diversas personas en relación con este negocio, contribuyeron en gran medida a disminuir los efectos causados por el fracaso de las tres negociaciones anteriores, que retrasaron la aprobación de la conversión por más de un año y ocasionaron una serie de problemas que, como veremos más adelante, afectaron profundamente a todos los interesados en el convenio.

En efecto, para cuando la propuesta de Murphy estuvo lista, en junio de 1846, la situación del país había variado drásticamente a causa de la guerra con los Estados Unidos y los planes que habían diseñado Escandón y los demás involucrados en la conversión tuvieron que ser modificados. De acuerdo con la información proporcionada por este último, al momento de hacerse la segunda propuesta, en septiembre de 1845 , se había calculado que los bonos de este fondo "subirían antes de dos meses a 45\%", pero el rechazo del convenio impidió que se cumplieran estas expectativas. Sin embargo, lo que realmente determinó que los cálculos iniciales se vinieran abajo fueron las noticias que llegaron a Londres sobre "las derrotas del ejército mexicano, la toma de Matamoros, el bloqueo de los puertos, y lo peor de todo, la orden de suspensión de pagos y toma de caudales de los dividendos ingleses en Veracruz" y aunque Escandón advierte que esta última noticia aún no se conocía de manera oficial, ello ocurriría muy pronto debido a la llegada del paquete inglés y "cuando se sepa causará un griterío que no sé hasta dónde llegará a bajar el precio de los bonos". ${ }^{21}$

Pero aún sin la confirmación de la peor parte, las noticias sobre la mala situación de México ya habían comenzado a perjudicarlos. Unos días antes, el 5 o 6 de junio, la casa de Schneider estaba negociando, con grandes posibilidades de éxito, la venta de $£ 500.000$ en bonos al $31 \%$ de su valor, pero poco después todo el negocio se arruinó y en ese momento ya no era posible colocar en la plaza los bonos, pues además de que sería una imprudencia "[...] no habría quien los com-

21 Véase nota 20. 
prara si no era haciéndolos bajar a $20 \%$, desacreditando así nuestro papel".22

Sin desanimarse por todos estos inconvenientes y muchos más que reseña a lo largo de su carta, Escandón continúa diseñando estrategias para evitar que las pérdidas sean aún mayores y decide aprovechar el tiempo que falta para que lleguen a Londres las temidas noticias, en tratar de vender $£ 400.000$ en bonos al $25 \%$. Aunque no logra cumplir este propósito, a pesar de los esfuerzos realizados por él y por Schneider, sí consigue vender cerca de $£ 130.000$ de bonos al 26\%.

Sin embargo, los problemas de los concesionarios a causa del retraso en la aprobación del convenio apenas empezaban. Con la guerra se agudizaron en México los conflictos políticos, el Gobierno del general Mariano Paredes fue depuesto y poco tiempo después, el 28 de agosto, el nuevo ministro de Hacienda, Valentín Gómez Farías, desconoció el convenio que se había celebrado durante la administración anterior y relevó a Murphy de su cargo, acusándolo de haberse extralimitado en sus facultades y de que el nuevo convenio no respondía al espíritu del decreto de 5 de marzo de 1846. En octubre del mismo año, otro ministro de Hacienda, Antonio de Haro y Tamaríz, canceló esta decisión aprobando de nuevo el convenio, lo que provocó fuertes reacciones de la opinión pública en su contra y posteriormente su sucesor, José L. Villamil, volvió a desconocer la validez de la conversión. ${ }^{23}$

Las consecuencias de estos cambios de política fueron desastrosas para los tenedores de los nuevos bonos, pues como señala atinadamente Joaquín Casasús:

Estas tres resoluciones contradictorias, que sucesivamente se fueron recibiendo en Londres en los meses de septiembre, noviembre y diciembre, dadas por tres ministros de Hacienda, haciendo ver el último, que ni el primero ni el segundo habían tenido facultades para resolver asunto de tanta gravedad, produjeron en Londres un escándalo inconcebible, pero justificado. Los bonos tuvieron en la Bolsa bajas considerables, los

22 Véase nota 20.

23 Todo lo relacionado con este conflicto se encuentra reseñado en varias obras, entre las que se pueden consultar las de Bazant (1968); Payno (1862); Rosa (1848); Romero (1870) y Carballo (1998). 
acreedores resintieron quebranto de importancia, los periódicos prodigaron dicterios injuriosos contra la República. ${ }^{24}$

Desde luego que detrás de estos cambios de opinión y de la negativa de ratificar la conversión se encontraban en juego factores económicos y rivalidades personales pero, sobre todo, existían intrigas políticas. Ya desde agosto de 1846, uno de los socios de la firma Martínez del Río Hermanos, Pedro Ansoátegui, opinaba que Santa Anna se manifestaría contra la conversión porque a él no le había tocado ninguna parte de las ganancias, pero que una vez arreglado el negocio en Londres no le quedaría otro remedio que tratar de obtener "una buena tajada". ${ }^{25}$ No existen pruebas de que se haya intentado conseguir la aprobación mediante este recurso, pero de lo que sí tenemos indicios es de los intentos de ejercer presión por medio de la vía diplomática. El mismo Ansoátegui informa, al mes siguiente de su carta anterior, que el ministro inglés, Charles Bankhead, en compañía de Mackintosh, habían estado en Tacubaya y que algunos testigos le comentaron que al salir ambos de la visita "[...] se oyó a Santa Anna que decía con tono bastante desconcertado: ¡amenazarme con intervención!”. Sin embargo, más adelante señala que las opiniones estaban divididas, pues mientras unos decían que la reunión había sido para pedir que se levantaran las prohibiciones, otros aseguraban que era a causa de la conversión. ${ }^{26}$

Durante varios meses este negocio fue uno de los temas más comentados entre los círculos mercantiles de la ciudad de México, donde corría el rumor de que el interés del ministro Bankhead por apoyar la conversión se debía a que tenía una buena "tajada" en el negocio. Respecto a Mackintosh, algunos opinaban que su crédito "[...] lejos de subir ha de bajar con este negocio de escandalosa mala fe [...]". ${ }^{27} \mathrm{Al}$ margen de todos los comentarios a que seguramente habrá dado lugar esta transacción, es indudable que Mackintosh y Escandón debieron haber intentado, por todos los medios posibles, la ratificación de un

24 Joaquín Casasús, Historia de la deuda contraida en Londres, citado en Bazant (1968: 65).

25 ACMRF, carta de Pedro Ansoátegui a Gregorio José Martínez del Río, México, 27/29 de agosto de 1846.

26 ACMRF, carta de Pedro Ansoátegui a Gregorio José Martínez del Río, México, 23/26 de septiembre de 1846 .

27 ACMRF, carta de José Pablo Martínez del Río a Gregorio José Martínez del Río, México, 27 de septiembre de 1846. 
contrato en el que habían invertido tanto tiempo y del que esperaban obtener importantes beneficios.

No es posible conocer con exactitud todos los intereses que se encontraban involucrados en esta conversión, puesto que al hablar de ella generalmente se hace alusión únicamente a Mackintosh y, en ocasiones, a Escandón, pero de acuerdo con la información proporcionada por este último, para el momento en que se aprobó el plan de Murphy, tenían participación en dicho negocio la casa de Schneider y Cía., Powles, Juan Rondero, P. Fort y Landa. ${ }^{28} \mathrm{Y}$ aunque tampoco se sabe hasta qué grado dependían Mackintosh y sus socios del éxito de ésta para poder intentar otro tipo de especulaciones, podemos al menos tener una idea de la información que circulaba entre los empresarios mexicanos, a través del siguiente comentario:

Por Don Pedro Echeverría he sabido que la compañía asociada para la Conversión tienen entre ellos cosa de cuatro millones de bonos y, según un amigo del Talabartero [nombre con el que frecuentemente designaban a Mackintosh en su correspondencia] pasan de seis millones de libras. Don Pedro añadió que el primer préstamo hecho en Londres, de $5 \%$, fue abarcado casi todo por casas holandesas, que desde aquella fecha conservaban los bonos y que a estas casas las representa en Londres la de Baring, la cual estaba de acuerdo con el Talabartero y Cía. para dicha Conversión. El plan de ellos es de hacer pagar los dividendos con puntualidad por cierto tiempo para que suban los bonos y vender ellos con provecho; y para esto cuentan con la renta del tabaco $[\ldots]^{29}$

Aunque no es posible comprobar la exactitud de estas afirmaciones, es razonable suponer que detrás de este negocio estuvieran involucrados los intereses de algunas casas británicas, puesto que la de Baring había sido durante algún tiempo agente del Gobierno mexicano, encargada de pagar los dividendos de la deuda en Londres y fue la que llevó a cabo la primera operación de capitalización de los intereses adeudados de 1827 a 1831 (Payno 1862: 7-8). Además, estas noticias provenían de Pedro Echeverría, miembro de la conocida casa comercial Viuda de Echeverría e Hijos, quien había sido ministro de Hacienda en diversas ocasiones entre 1838 y 1845 y cuyo hermano, Javier Echeverría, había

28 En lo que respecta a la participación de Schneider y Cía., Escandón señala que había introducido $\$ 25.000$ en efectivo y $\$ 400.000$ en bonos del tabaco. Carta de Manuel Escandón a Ewen C. Mackintosh citada en la nota 20.

29 ACMRF, carta de José Pablo Martínez del Río a Gregorio José Martínez del Río, México, 5 de diciembre de 1846. 
ocupado varias veces el mismo puesto entre 1834 y 1841 , por lo que se puede considerar que se trataba de una fuente bien informada.

Mientras en algunos círculos se hacían conjeturas sobre sus propósitos, en marzo de 1847 Mackintosh y Escandón, sin saber aún si el negocio de la conversión sería finalmente aprobado, comenzaron a trazar un nuevo plan para arrendar el estanco del tabaco. Con ese objeto procuraron limar sus antiguas asperezas con los tenedores de bonos de la deuda del tabaco, representados por Martínez del Río Hermanos. Se proponían, luego de pagar renta al Gobierno por el usufructo del estanco, dividir las utilidades entre los plantadores, los tenedores de bonos y los socios de la nueva compañía. Además, una parte fija se destinaría a financiar la conversión de la deuda extranjera. ${ }^{30}$

Naturalmente, este plan iba encaminado a asegurar la conversión de la deuda, puesto que la renta del tabaco era una de las fuentes que se habían señalado para la amortización de los nuevos bonos y no era posible hipotecarla sin llegar primero a un arreglo con los demás acreedores de dicha renta. Lo que llama la atención es que el proyecto se haya comenzado a preparar desde marzo de 1847 , cuando la renta se encontraba totalmente desorganizada a causa de la invasión norteamericana, que había declarado libre el producto en los lugares ocupados por sus tropas, mientras que en el resto del país se había incrementado notablemente el contrabando. Sin embargo, un año más tarde, el Gobierno decide continuar con el estanco y el 19 de agosto de 1848 lo da en arrendamiento a algunos de sus acreedores (Romero 1870: 303-304), que casualmente eran Escandón, Mackintosh y Miguel Bringas, en las mismas condiciones que los dos primeros habían previsto con tanta anterioridad.

Este arrendamiento ocasiona conflictos entre algunos de los grupos interesados en el estanco, provocando fuertes críticas contra el ministro de Hacienda y, por supuesto, contra los contratistas, de cuyas consecuencias hablaremos más adelante. Pero lo que nos interesa destacar en este momento es que, a pesar de la negativa del Gobierno a ratificar la conversión, Mackintosh y Escandón no dejaban de trabajar

30 Walker (1991: 258-259). Para todo lo relacionado con el conflicto entre Mackintosh y Escandón con el resto de los tenedores de los bonos del tabaco, representados por Martínez del Río Hermanos, consultar el capítulo "Los bonos de la deuda del tabaco y las convenciones, 1845-1861". 
en ella y de buscar la manera de reducir las pérdidas que podría ocasionarles este retraso.

Sin embargo, sus esfuerzos no pudieron evitar que el negocio se complicara con la guerra y que la amistad de Santa Anna con los Lizardi interfiriera en la aprobación de la conversión. Ante la falta de resultados por parte de su agente en México, los tenedores de bonos en Londres decidieron utilizar sus propios recursos. Al enterarse, en enero de 1847 , de que las autoridades mexicanas habían comunicado a su nuevo ministro plenipotenciario en Londres, José M. ${ }^{\mathrm{a}}$ Luis Mora, su intención de desconocer los arreglos realizados por Murphy, acudieron al secretario de Asuntos Exteriores, Lord Palmerston, solicitando la mediación del ministro británico en México, Charles Bankhead, en favor de los tenedores de bonos. En respuesta a sus constantes peticiones de ayuda, Bankhead comenzó a presionar, por la vía diplomática, el reconocimiento de la conversión.

Finalmente, el 20 de julio de 1847, el Gobierno mexicano decide reconocer la conversión efectuada por Murphy en 1846 y el general Santa Anna declara que da este paso por consideración a la Gran Bretaña y a las gestiones realizadas por Bankhead. En opinión de Alfonso Carballo (1998: 52), fueron las quejas de los tenedores de bonos las que determinaron las acciones de Lord Palmerston y Mackintosh no tuvo mucho que ver en esta decisión.

De cualquier manera, él había sido informado oportunamente de la inminente ratificación de la conversión, así que un día antes de que la noticia se diera a conocer oficialmente, celebra un nuevo contrato con el ministro de Hacienda, Juan Rondero, en el que se introducen varias modificaciones respecto a las condiciones acordadas en marzo de 1846. Como se puede observar por la información contenida en el anexo 3, con estas nuevas propuestas Mackintosh y Escandón buscaban reducir las pérdidas ocasionadas por la baja considerable que habían sufrido los nuevos bonos a causa de todos los incidentes ocurridos en torno a la conversión. ${ }^{31}$

Resulta sorprendente la similitud que existe entre varias de las modificaciones introducidas en este nuevo convenio y los planes que Escandón había expuesto a Mackintosh en su carta del año anterior.

31 Según Carballo (1998: 47), para noviembre de 1846 el precio de los bonos se había hundido a $21 \%$. 
Sin embargo, estas coincidencias se pueden explicar fácilmente si tomamos en cuenta que, en aquella ocasión, Escandón había recomendado a Mackintosh recurrir a Rondero para arreglar las dificultades que se presentaran en México pues, además de las buenas relaciones que existían entre ambos, Rondero resultaba involucrado en el negocio de acuerdo con los nuevos planes diseñados por Escandón. ${ }^{32}$ Desde luego, lo que este último no podía haber previsto era que Rondero sería ministro de Hacienda precisamente en el momento más adecuado para ayudarle a conseguir sus propósitos.

\section{Otros negocios}

Al margen de la serie de incidentes relacionados con el asunto de la conversión, que desde 1845 consumieron buena parte del tiempo y de los esfuerzos de Mackintosh, la firma había continuado con sus actividades mercantiles y financieras, además de seguir realizando diversos negocios con el Gobierno.

Entre ellos se encuentran los contratos de 3 y 6 de abril de 1846 sobre los cuales no tenemos información muy precisa, a pesar de ser mencionados frecuentemente en diversos documentos de la época y de las serias repercusiones que tuvieron para la casa contratista. De acuerdo con los datos disponibles, en estos contratos, que fueron aprobados en junta de ministros, ${ }^{33}$ Manning y Mackintosh se comprometían a dar al Gobierno $\$ 600.000$ en efectivo, entregando $\$ 50.000$ en ese momento y el resto en mensualidades por la misma cantidad en Zacatecas. Ofrecían también \$ 540.000 en bonos del 26\% y $\$ 700.000$ en créditos reconocidos. A cambio de esto el Gobierno quedaba obligado a entregar dos barcos de vapor que se habían comprado recientemente en Inglaterra por el precio de \$600.000 -los cuáles aún no se habían terminado de pagar-para procurar su venta en La Habana, por cuenta y riesgo del Gobierno, debiendo recibir Mackintosh $\$ 380.000$ del producto de la venta. Además se le entregarían $\$ 50.000$ del derecho del 3\% de plata en pasta, $\$ 450.000$ en derechos

32 Carta de Manuel Escandón a Ewen C. Mackintosh citada en la nota 20.

33 Los ministros en ese momento eran: de Relaciones Interiores y Exteriores, José María de Castillo y Lanzas, de Justicia el obispo Luciano Becerra, de Guerra y Marina, José María Tornel y de Hacienda, Manuel E. Gorostiza. 
de circulación y exportación y $\$ 960.000$ en bonos del 26\% (Romero 1870: 930).

Aunque, como ya hemos señalado, esta clase de negocios en los que se incluía una fuerte cantidad de papeles de la deuda pública eran muy frecuentes y la casa había realizado antes varias operaciones de este tipo, en esta ocasión hay algunos detalles interesantes.

Por una parte resulta claro que en el momento que se celebraron, abril de 1846, el Gobierno del general Mariano Paredes enfrentaba una situación financiera bastante difícil a causa de la inminente guerra con los Estados Unidos y requería urgentemente de fondos, sin embargo, no parece probable que $\$ 50.000$ mensuales fueran a ser de gran ayuda. Por otra parte, estaba la urgencia del Gobierno por deshacerse de los vapores, ya que en caso de guerra era muy probable que los Estados Unidos se apoderaran de ellos, así que se hace una venta fingida a Mackintosh, cuya calidad de cónsul británico ofrecía una garantía para que pudieran ser vendidos sin problemas. Los beneficios que obtenía Mackintosh eran evidentes, pues además de admitírsele una proporción enorme de papeles de la deuda pública - en este caso se trata de una operación en la que se recibía un poco menos del 33\% en efectivo a cambio del $67 \%$ restante en créditos, la mayoría de los cuáles pertenecían a la clase que tenía el valor más bajo en el mercado- se garantizaba el reembolso de su inversión con el precio de los vapores y $\$ 500.000$ en derechos que él se encargaría de hacer efectivos, puesto que estaban directamente relacionados con los negocios mercantiles y de transferencia de recursos que su casa efectuaba, tanto al interior del país como en el extranjero. Lo que ya no resulta tan claro es que además se le dieran, como parte del pago, \$960.000 en bonos del $26 \%$, pues se supone que el Gobierno no debía participar en especulaciones con papeles de la deuda pública y que cualquier clase de bonos que ingresaran en la Tesorería debían ser destruidos para evitar que volvieran a entrar en circulación, puesto que la única justificación que tenía el Gobierno para aceptarlos como parte de un negocio, era que de esa forma se lograba disminuir el monto de la deuda pública. Es muy probable que estas condiciones estuvieran relacionadas con algún otro negocio que les permitiera utilizarlos un poco más adelante, y esta probabilidad aumenta si tomamos en cuenta que, en la tercera propuesta para la conversión de la deuda, hecha en marzo de ese mismo año, se incluía una fuerte cantidad de estos bonos. 
Si el contrato se hubiera llevado a cabo tal como estaba estipulado, Mackintosh habría obtenido una buena ganancia, pues por un total de $\$ 791.000,{ }^{34}$ el Gobierno terminaría pagándole \$ 1.120.000. Sólo que, como ellos mismos habían comprobado en ocasiones anteriores, era muy poco frecuente que las cosas salieran tal como se habían planeado. Por principio de cuentas, los vapores fueron vendidos a España por $\$ 160.000$, de los cuales únicamente se pagaron en ese momento $\$ 50.000$, mientras que el resto se cubriría en abonos de $\$ 6.000$ mensuales. ${ }^{35}$ No sabemos si las demás condiciones se cumplieron, aunque suponemos que no todas, puesto que unos años más tarde Mackintosh reclama la cantidad de $\$ 584.000$ por falta de cumplimiento de parte del Gobierno a dichos contratos (ver anexo 4). De lo que sí tenemos evidencias es de que, en la serie de ataques que poco tiempo después se desataron en su contra, el asunto de los vapores ocupó varias veces la atención pública y la prensa lo utilizó como un ejemplo del tipo de negocios fraudulentos que el cónsul acostumbraba a realizar.

La participación de Mackintosh en negocios conflictivos parece convertirse en una constante y la tendencia a utilizar su nacionalidad y su posición diplomática en beneficio de sus intereses financieros se vuelve a poner de manifiesto en enero de 1847, cuando aparece como cesionario de un privilegio que el Gobierno había concedido en 1842 a José Garay para la construcción de una vía de comunicación interoceánica a través del Istmo de Tehuantepec y para la colonización de esa región con grupos de extranjeros que impulsaran principalmente las actividades agrícolas de la zona. Esta concesión se caracterizó desde el inicio por una serie de irregularidades en su manejo, las cuales fueron aumentando con el tiempo, hasta el grado de ocasionar al Gobierno serios conflictos internacionales. Como desde un principio Garay no contaba con los recursos necesarios para una empresa semejante, el privilegio caducó y fue prorrogado sin que el contratista cumpliera con ninguna de las obligaciones que había adquirido. Con el objeto de formar una compañía para explotar esta concesión, Garay se

34 Hay que recordar que para este momento estamos calculando que los bonos del $26 \%$ tenían un valor real de un $25 \%$, mientras que los "créditos reconocidos" valían aproximadamente un $8 \%$. Al respecto pueden consultarse las notas del anexo 2.

35 El Siglo Diez y Nueve, 8 de febrero de 1850. 
marcha a Europa ${ }^{36}$ y celebra un contrato con las casas de Manning y Mackintosh y de John Schneider y Cía., en agosto de 1846, por medio del cual les cede todas las tierras que quedaban comprendidas en una extensión de diez leguas a cada lado del río Coatzacoalcos, con el objeto de emprender la colonización de esta zona.

A cambio de la cesión de esta parte de su privilegio, Garay obtendrá un tercio de las utilidades que produzca el negocio y aunque el convenio se realiza de manera privada en agosto de 1846 , no se consigna en escritura pública sino hasta enero de $1847 .{ }^{37}$ José Fernando Ramírez, en una voluminosa obra dedicada a analizar todas las irregularidades ocurridas con esta concesión, señala que el objetivo principal de Garay en ese momento era involucrar a súbditos ingleses en el negocio para que el Gobierno mexicano se viera obligado a prorrogar una vez más el privilegio, que ya para entonces había caducado (Ramírez 1853: 40).

Al parecer, la estrategia funcionó como se esperaba, pues el 5 de noviembre de 1846, el Gobierno provisional de Mariano Salas le concede una prórroga de dos años (Suárez Argüello 2003: 24).

Sin saber si el Gobierno aprobaría el contrato de colonización, Garay celebró, el 12 de marzo de 1847, otro convenio privado con Mackintosh, en el cual le cedía el privilegio para la construcción de la vía interoceánica a través del Istmo de Tehuantepec. De acuerdo a este convenio, Mackintosh debía procurar la venta del privilegio y, una vez

36 Una prueba de que el negocio resultaba bastante complicado la tenemos en el hecho de que el hermano de José Garay, el conocido agiotista veracruzano Antonio Garay, comienza a financiar la empresa, pero cuando la suma invertida llega a los 100.000 pesos decide no correr más riesgos y obliga a su hermano a firmarle un reconocimiento por la cantidad adeudada y a hipotecarle la concesión como seguridad para el pago. ANCM, notario Francisco Madariaga (1843, f. 1126v.). Cuando José se va a Europa gira algunas libranzas contra la casa de su hermano, pero éste decide no aceptarlas, señalando que no tiene fondos del girador. ANCM, notario Pablo Sánchez (marzo, octubre y noviembre de 1846, fs. 23v., $157 v$ y $168 v$.). Esto nos muestra que, a pesar de que en un principio Antonio estaba decidido a financiar a su hermano, su actitud cambia cuando los costos se elevan demasiado sin que se logren avances significativos. A partir de ese momento se mantiene firme en esa decisión y no vuelve a participar a pesar de las buenas expectativas que el negocio ofrece posteriormente. Lo anterior permite comprobar que, en varias ocasiones, los empresarios nacionales tienen una visión más clara de los riesgos que implican este tipo de negocios y prefieren no mezclarse en ellos.

37 ANCM, notario Ramón de la Cueva (1847, f. 26). 
conseguido este propósito, entregaría a Garay la tercera parte del producto de dicha venta - de la cual restaría el $10 \%$ de comisión y $1 \frac{2}{2} \%$ de corretaje- además de $\$ 150.000$ adicionales por lo que ya se había gastado en el negocio. Este convenio privado no se formaliza hasta el 28 de octubre de 1848 por medio de una escritura notarial. ${ }^{38}$

Como se puede observar, en esta ocasión se repite la táctica empleada con anterioridad y los convenios se realizan primero de manera privada, probablemente porque de esta forma se podían modificar algunas de las condiciones de acuerdo con la manera en que se desarrollaran los acontecimientos. Aunque no se conocen las propuestas originales hechas en marzo de 1847, es posible suponer que existían ciertas vinculaciones entre este negocio y la conversión de la deuda de 1846, pues en ambos casos intervienen las firmas de Manning y Mackintosh y de John Schneider y Cía. La participación de Manuel Escandón se inicia poco tiempo después cuando, en junio de 1847, Schneider decide renunciar al tercio que le corresponde en la concesión y dividirlo en dos sextas partes, de las cuales una pertenece a Mackintosh y la otra a Escandón (Suárez Argüello 2003: 26). No se cuenta con mayor información sobre las condiciones en que se realizó esta transferencia, pues en su correspondencia con Mackintosh, Schneider y Cía. sólo señalan que, debido a que ha terminado su participación en todo lo relacionado con el contrato de agosto de 1846, declinan la propuesta de ratificar el convenio celebrado entre Mackintosh y Garay en relación con la cesión de los privilegios para abrir una vía de comunicación a través del Istmo de Tehuantepec. ${ }^{39}$ Lo lacónico de esta respuesta permite suponer que Schneider y Cía. no tenían ningún interés en seguir involucrados en este asunto, así que su participación inicial y la posterior transferencia a Mackintosh y a Escandón probablemente fueron resultado de los tratos que celebraron con este último para la compra de bonos de la deuda consolidada.

Sin embargo, Mackintosh sí continuaba muy interesado en el negocio de Tehuantepec y para finales de 1848 aparece como el único dueño del privilegio, a causa de una cesión fingida por parte de Garay

38 ANCM, notario Ramón de la Cueva (1848, f. 858v) y Suárez Argüello (2003: 2627).

39 BLAC, Manning and Mackintosh Papers, Serie 1, Correspondencia, carta de John Schneider y Cía. a Manning y Mackintosh, Londres, 1 de septiembre de 1847. 
para poder negociar la venta de la concesión, pues como señala Ana Rosa Suárez Argüello:

La presentación de Manning y Mackintosh como la única poseedora del contrato le permitiría ejercer una mayor presión sobre el Gobierno mexicano y acaso lograr la intervención extranjera. Por su parte, la firma británica hacía un buen negocio, al parecer sin poner un centavo, sólo por su mediación. ${ }^{40}$

De acuerdo con estos propósitos, en el mismo mes de octubre autorizó a la firma de Hargous Brothers de Nueva York para que comenzara a gestionar la venta de la concesión en el extranjero. Sólo que, como ya se había hecho costumbre, hasta este momento ni él ni Garay habían considerado necesario informar al Gobierno mexicano sobre los contratos que habían celebrado desde 1847.

Así que los verdaderos problemas comienzan en enero de 1849 , cuando la casa de Manning y Mackintosh dirige una nota al Gobierno informándole de que Garay les había cedido el privilegio de la construcción de una vía de comunicación entre los dos mares a través del Istmo de Tehuantepec, ${ }^{41}$ para cuya obra ya habían comenzado a realizar algunos trabajos, pero como el costo era tan elevado sus agentes estaban tratando de interesar a otras casas extranjeras en la empresa.

En opinión de Ramírez (1853: 62), este ultraje hecho al Gobierno mexicano, sin avisarle nada de lo que se había ejecutado a sus espaldas, era suficiente para declarar nulo todo el privilegio. Pero además, existían irregularidades mayores, como era el hecho de que, en la escritura de 27 de octubre de 1848, se señalara que Garay había cedido esta parte del privilegio mediante un convenio secreto celebrado en marzo de 1847, cuando el Gobierno mexicano no había aprobado siquiera el convenio relativo a la colonización. A todo lo anterior, se debía añadir el hecho de que, sin haber informado ni mucho menos obtenido autorización del Gobierno mexicano, Manning y Mackintosh ya habían comisionado a la casa Hargous, de Nueva York, para que procediera a enajenar, bien fuera a particulares o a compañías, los privilegios cedidos por Garay. Como todo esto ocurre un día antes de que expirara la última prórroga concedida por el Gobierno y como aún no se había dado comienzo a ninguna obra relacionada con la vía de

40 Suárez Argüello (2003: 27).

41 ANCM, notario Ramón de la Cueva (1848, f. 864v.). 
comunicación, resultaba evidente que Garay volvía a recurrir al mismo procedimiento empleado en 1847 , cediendo ahora todo el privilegio y además traspasándolo a una tercera nación para mayor seguridad (Ramírez 1853: 62-65).

$\mathrm{Al}$ ser tantas las irregularidades que se cometen en este negocio y tan contradictorias las declaraciones que hacen los interesados en sus diversos comunicados, es muy difícil determinar cuál fue la verdadera participación de Manning y Mackintosh en el asunto, ya que, para conseguir la protección británica, en diversas ocasiones se afirma que su casa es la única dueña de la concesión. ${ }^{42}$ Sin embargo, la situación financiera de la firma y el creciente interés que Hargous Brothers va tomando en el asunto provocan que su participación sea cada vez menos importante. Finalmente, en enero de 1850, Manning y Mackintosh cede su sexta parte del contrato a Mariano Gálvez, en pago de un adeudo pendiente. ${ }^{43}$

A partir de este momento, la casa de Manning y Mackintosh pierde toda injerencia en el negocio de Tehuantepec y adquieren relevancia en la concesión de Garay nuevos protagonistas, al grado de que algunos autores prefieren referirse a ella como la concesión HargousEscandón (Terrazas y Basante 2000: 19).

La evidente ilegalidad con que se condujeron tanto el dueño original como las distintas casas extranjeras involucradas en el privilegio provocó una reacción previsible entre la opinión pública y los círculos políticos mexicanos. La pretensión de Hargous Brothers de ser reconocidos como cesionarios de todos los derechos del privilegio de Garay se enfrentó con el rechazo del Congreso mexicano. En mayo de 1851 se decidió anular este privilegio aduciendo que la prórroga concedida por el general Salas no tenía validez. ${ }^{44}$ La insistencia de los

42 En lo que respecta al interés cada vez mayor que muestra la firma de Hargous Brothers en el asunto y a las diversas tentativas que realiza para obtener el reconocimiento mexicano, se debe consultar el trabajo de Ana Rosa Suárez Argüello (2003) en el que se analizan los conflictos políticos y diplomáticos que tuvieron lugar, tanto en México como en Estados Unidos, a causa de la defensa de los intereses económicos de los diversos empresarios involucrados en los proyectos de construcción de una vía de comunicación por el Istmo de Tehuantepec.

43 ANCM, notario Ramón de la Cueva (14 de febrero y 10 de junio de 1850, fs. 645-648).

44 Los esfuerzos hechos por la firma de Hargous Brothers para lograr el reconocimiento mexicano culminaron con la elaboración del Tratado de Tehuantepec, sin 
cesionarios en que México reconociera la legitimidad de sus derechos ocasionó serios conflictos diplomáticos entre ambas naciones, pues el Gobierno de los Estados Unidos, al asumir la defensa de los intereses de Pedro Hargous y de otros norteamericanos en dicho proyecto, llegó a recurrir incluso a las amenazas, poniendo en peligro las relaciones entre los dos países. $^{45}$

Desde luego, la participación de Mackintosh en la serie de operaciones fraudulentas relacionadas con el asunto de Tehuantepec no contribuyó mucho a mejorar la mala reputación que ya se había ganado en México, pero lo más sorprendente es que algunos años más tarde incluye entre sus reclamaciones al Gobierno mexicano la cantidad de $\$ 500.000$, como indemnización por los daños que había sufrido con la anulación del privilegio de Garay (ver anexo 4), cuando él mismo había declarado en diversas ocasiones, y además existían escrituras públicas que lo demostraban, que había vendido toda su participación en ese negocio en 1850 , o sea dos años antes de su anulación.

Para los empresarios interesados en el privilegio de Tehuantepec, el asunto de la colonización era un objetivo bastante secundario, mientras que para el Gobierno se trataba de una cuestión de gran importancia, que ocupó su atención durante varios años. Los intentos por fundar colonias con extranjeros "inteligentes y laboriosos" fueron constantes, aunque sus resultados nunca correspondieron a las expectativas gubernamentales.

De acuerdo con esta política de fomento a la colonización se dieron varias concesiones, tanto de tierras como fiscales, en un intento por poblar con estos colonos las zonas más deshabitadas del país y de esta manera proteger el territorio, además de fomentar las actividades económicas, especialmente la agricultura.

embargo éste también fue rechazado por el Congreso en abril de 1852 . En relación con los diversos problemas que se suscitaron entre lo dos países a causa de esta concesión, ver Ramírez (1853), Suárez Argüello (2003) y Terrazas y Basante (2000).

45 La estrategia del Gobierno mexicano de contrarrestar la influencia de Hargous Brothers mediante la creación de otra empresa, formada por mexicanos y extranjeros, complicó aún más la situación. La magnitud de los intereses involucrados en estos intentos de construir una vía de comunicación interoceánica a través de Tehuantepec fueron motivo de constantes presiones para los Gobiernos de la época y se prolongaron hasta 1868 (Terrazas y Basante 2000: 89). 
Es dentro de esta política donde se inscribe la concesión que el Gobierno de Santa Anna otorgó, en octubre de 1843, al barón Alejandro de Grox, súbdito de Bélgica, al aprobar el plan que le había presentado para la colonización de los terrenos baldíos en el departamento de Tamaulipas. De acuerdo con las condiciones estipuladas en el decreto correspondiente, el empresario se obligaba a colonizar ese departamento, trayendo a sus expensas a cuando menos mil familias belgas, alemanas y suizas en el término de diez años, para dedicarlas al cultivo de las tierras que se les designaran y estableciendo dichas colonias a una distancia de veinte leguas de la frontera. Se señalaba la cesión de terrenos baldíos que se hacía con este objeto y la que se otorgaba especialmente al empresario, quien en cada una de las colonias que fundara podría disponer, en calidad de propietario, de una parte que no excediera de la mitad de los terrenos distribuidos a los colonos, los cuales, al tomar posesión de sus tierras, serían considerados como ciudadanos mexicanos bajo la protección del Gobierno, sin perder por ello su nacionalidad de origen. Además, estarían exentos de toda contribución por diez años y podrían introducir, ya fuera por Matamoros o por cualquier otro puerto habilitado en el mar del Norte, todo lo que necesitaran para el fomento de la colonia y para sus necesidades particulares, libre de todo gravamen, por el mismo periodo de diez años.

También se autorizaba al empresario para transferir a otro los derechos que había adquirido, siempre y cuando diera previo aviso al Gobierno y con expresa aprobación de éste. Además, se señalaba claramente que si en el término de diez años el empresario no hubiera introducido las mil familias acordadas, se daría por rescindido el privilegio (Dublán/Lozano 1876-1902, V: 620-621).

En junio de 1848 , en vista de que ya habían transcurrido cinco años sin poder obtener ningún resultado positivo, y necesitando asociarse con alguien que le facilitara los recursos para llevar a cabo su proyecto, De Grox decide celebrar un convenio con la casa de Manning y Mackintosh, por medio del cual les cede la cuarta parte de las utilidades líquidas que produzca la colonización, bien sea por ventas parciales que se hagan de los terrenos cedidos a De Grox o bien de los productos o rentas que se perciban de los colonos. A cambio de esto, Manning y Mackintosh se obligan a emplear sus relaciones mercantiles y todos los medios a su alcance para lograr los propósitos de la 
sociedad. Como no se puede calcular cuánto deberá invertir la casa en este negocio, por el momento dará al empresario $\$ 2.000$ para sus gastos personales, comprometiéndose además a suministrarle las cantidades necesarias para sus viajes, por el tiempo que convengan ambas partes. Los $\$ 2.000$ y el resto que se necesite ganarán un rédito del $6 \%$ anual y serán reembolsados de las primeras utilidades que obtenga la sociedad. ${ }^{46}$ Como una parte de los terrenos cedidos queda ahora en territorio de los Estados Unidos, las gestiones de Mackintosh respecto al territorio comprendido entre el río Nueces y el Bravo se limitarán a proponer su venta, ya sea a particulares o al Gobierno de los Estados Unidos y a hacer los trámites necesarios para que éstos reconozcan los títulos que tiene De Grox de dichos terrenos. ${ }^{47}$

Para 1850 se hacen algunas modificaciones al contrato y en esta ocasión se ceden a Manning y Mackintosh la mitad de la propiedad y de las utilidades líquidas que produzca la colonización, a cambio de lo cual la casa se compromete a proporcionar a De Grox $\$ 250$ mensuales para sus gastos personales por el término de tres años, al cabo de los cuales pueden dejar de dar esta cantidad si el proyecto no se ha realizado. ${ }^{48}$

Parece que en esta ocasión no fueron de gran ayuda para el empresario las "relaciones mercantiles" que la casa de Manning y Mackintosh se había comprometido a emplear en provecho de la empresa, pues para 1853 ésta sigue sin mostrar ningún avance. En un nuevo intento por sacarla adelante, De Grox se asocia con Francisco Falconnet, a quien cede la tercera parte de las utilidades que produzca el negocio a cambio de un adelanto de $\$ 4.000$ y un aporte mensual de $\$ 250$ por un periodo de tres años. Manning y Mackintosh no sólo están de acuerdo con esta cesión, sino que además declaran que la tercera parte que ahora representan la tienen hipotecada a Falconnet, desde mayo de 1852 , por un adeudo de $\$ 253.645$, por lo que ahora éste tendrá la representación de ambos y de la utilidad líquida que les

46 Como se puede observar, en muchas de estas condiciones existe una gran similitud con los contratos de avío de minas.

47 ANCM, notario Francisco Madariaga (1848, f. 312).

48 ANCM, notario Francisco Madariaga (1850, f. 833). 
corresponda en la empresa se rebajará primero la cantidad adeudada a Falconnet. $^{49}$

No encontramos noticias sobre los adelantos que haya tenido la empresa, aunque parece ser que no hubo ninguno. En todo caso, De Grox se hizo de algunas cantidades por las diversas cesiones que otorgó, pero no logró el propósito de la colonización. Lo que resulta extraño es que no se haya declarado la nulidad del privilegio en marzo de 1853, como lo señalaba el decreto original. Tal vez se obtuvo una prórroga o el Gobierno no le prestó mucha atención al asunto; el caso es que el decreto fue derogado en 1861 .

En lo que ya resulta una forma típica de conducirse, Mackintosh hace una reclamación de $\$ 7.953 .722$ por falta de cumplimiento por parte del Gobierno en lo relativo a este convenio (ver anexo 4). En esta ocasión, realmente no se puede explicar la pretensión de Mackintosh, pues si acaso hubiera llegado a cubrir todas las cantidades que había ofrecido al dueño del privilegio, cosa que resulta bastante dudosa puesto que el compromiso de los $\$ 250$ mensuales lo adquirió en 1850 , en momentos en que la situación financiera de la casa no debe haberle permitido hacer ningún desembolso que no fuera absolutamente indispensable, resultaría que había gastado en total $\$ 11.000$ en este negocio y por esa inversión pretendía cobrar una indemnización de casi ocho millones de pesos. Como en el caso de Tehuantepec, él hace la reclamación en 1855 , a pesar de que desde 1852 ya no tenía ningún derecho sobre este negocio por haberlo hipotecado a Falconnet. Además, resulta sorprendente que se hable de falta de cumplimiento por parte del Gobierno, cuando fueron el dueño del privilegio y sus cesionarios quienes no cumplieron con ninguna de las condiciones estipuladas en el contrato original.

Me parece que éste es un buen ejemplo de lo que podríamos llamar "negocios sobre el papel", puesto que las únicas acciones que se emprendieron fueron los otorgamientos de las diversas escrituras y un desembolso por parte de cada uno de los cesionarios, que no sabemos realmente a cuánto ascendió, pero que lo más probable es que no haya

49 ANCM, notario Ramón de la Cueva (1853, f. 15). En realidad el adeudo no lo tienen con Falconnet, sino con los tenedores de bonos mexicanos en Londres a quienes éste representa. 
llegado siquiera a las cantidades señaladas en los contratos respectivos.

Aún tratándose de Mackintosh, resulta absurda la pretensión de reclamar una suma semejante, que equivaldría a más de la mitad del monto de la indemnización norteamericana en 1848, por un negocio que ni siquiera se llevó a cabo. Tal vez esta conducta pudiera interpretarse como una muestra de su enorme voracidad frente a lo que él consideraba un Gobierno débil y susceptible de ser obligado, por la vía diplomática, a llegar a algún tipo de negociación, o quizá como la reacción propia de alguien que, habiéndolo perdido todo en muy poco tiempo, estaba también perdiendo el sentido de la realidad.

Más adelante hablaremos brevemente de algunas de las reclamaciones que Mackintosh pretendía hacer al Gobierno mexicano, entre las cuales se encuentran las relacionadas con la famosa conversión de la deuda.

En lo que respecta a lo ocurrido con este negocio después de la aprobación de la conversión de 1846, cabe señalar que durante algún tiempo este reconocimiento no fue de mucha utilidad para los tenedores de los nuevos bonos, pues a pesar de los deseos del Gobierno de cumplir con las obligaciones recién adquiridas, el país se encontraba en esos momentos en plena guerra con los Estados Unidos y no pudo abonar ni uno solo de los pagos que debía hacer semestralmente, lo que ocasionó una explicable inquietud entre los tenedores de bonos.

La situación pareció mejorar cuando se recibió en Londres la noticia de que las negociaciones de paz habían culminado con la elaboración del Tratado de Guadalupe Hidalgo, que contenía entre sus estipulaciones el compromiso de los Estados Unidos de pagar a México una indemnización de 15 millones de pesos a cambio de la cesión de más de la mitad del territorio nacional. La ratificación de este tratado por parte del Congreso mexicano, en mayo de 1848, marcó el inicio de un fuerte enfrentamiento entre diversos grupos por definir el uso que se debía dar a este dinero.

Uno de los grupos más activos era el representado por Escandón y Mackintosh, cuyos intereses estaban fuertemente vinculados con los de los tenedores de bonos. Acerca de sus proyectos sobre el uso que debía darse a la indemnización, Mariano Otero comenta:

Escandón está empeñadísimo en que los millones de la indemnización se destinen a la deuda exterior, verificando una operación por la cual se 
amortice considerable cantidad de bonos y se haga una nueva conversión, reduciendo el rédito al 3\%, operación en que tienen grande interés el cónsul inglés [Mackintosh] y los demás agentes, tanto nacionales como extranjeros, del último contrato.

Considera, además, que dicho contrato ha sido gravoso tanto para México como para los acreedores "[...] sin haber dejado utilidad más que al mismo Escandón y a algunos funcionarios públicos, cuyos votos y órdenes se compraron descaradamente". ${ }^{50}$

Desde luego Otero no está de acuerdo con estos planes y señala que, mientras él sea ministro, ${ }^{51}$ no se llevará a cabo dicha operación, en la que este grupo había puesto tanto empeño desde la época en que se estaban llevando a cabo las negociaciones del tratado de paz.

Sin embargo, tanto Escandón como Mackintosh, insisten en su pretensión de que el dinero se destine al pago de los acreedores de la deuda externa. De esta manera continúan alentando durante algún tiempo las esperanzas de los tenedores de bonos, que confiaban en la influencia de estos dos personajes para convencer a las autoridades mexicanas y llevar a cabo sus propósitos. Es difícil determinar hasta qué punto compartían ellos también estas expectativas, o si se trataba sólo de una maniobra para evitar que el valor de los bonos siguiera bajando en Londres. Lo cierto es que la actitud hostil del Congreso y de varios funcionarios públicos no dejaba lugar para alentar muchas esperanzas. Además, aunque hubieran podido utilizar su influencia con algunos funcionarios, era bien poco lo que se podría lograr, puesto que desde el 14 de junio de 1848, se había expedido una ley que prohibía al ejecutivo disponer de manera alguna de los doce millones que quedaban disponibles de la indemnización, sin la autorización del Congreso (Romero 1870: 299).

Así que, cuando el Comité de Tenedores de Bonos se dio cuenta de que su representante en México era incapaz de defender sus intereses, decidió enviar un agente especial para tratar el asunto. Con este objeto llegó a México, en marzo de 1849, Guillermo P. Robertson,

50 Carta de Mariano Otero a José María Luis Mora, 12 de agosto de 1848, en García (1906, VI: 101-102).

51 En este momento Otero era ministro de Relaciones y en su correspondencia con Mora hace constantes alusiones a este tema, pues considera que Mora, en su calidad de ministro plenipotenciario de México en Londres, debe estar bien informado sobre lo que está ocurriendo en el país respecto a un asunto en el que están involucrados varios intereses británicos. 
quien después de algunas negociaciones, celebró un convenio con el ministro de Hacienda, Francisco Arrangoiz, de acuerdo con el cual se destinarían cuatro millones de pesos, procedentes de la indemnización, para cubrir los réditos adeudados a los tenedores de bonos desde julio de 1846 (Payno 1862: 17-19).

Este convenio, que "no agradó ni en México ni en Londres" (Bazant 1968: 70), fue rechazado por el Congreso, el cual pidió a la Comisión de Crédito Público de la Cámara de Diputados, la elaboración de un dictamen sobre este asunto, mismo que fue presentado en abril de 1850. Manuel Payno, quien formaba parte de dicha comisión, señala que el dictamen fue traducido al inglés y publicado en Londres, donde recibió tan buena acogida que hizo subir el valor de los bonos entre 3 y 4\% (Payno 1852: 10-11).

En julio de 1850 , el mismo Payno, ahora como ministro de Hacienda, sostiene varias reuniones con los miembros del Congreso para tratar el asunto de la deuda externa. Como resultado de estas discusiones, se expide el decreto de 14 de octubre, que es presentado a los tenedores de bonos en Londres para su discusión, a pesar de la oposición del nuevo agente enviado por el Comité, Francisco Falconnet, quien aún intentaba obtener de la indemnización algunos de los grandes beneficios prometidos por Mackintosh y Escandón.

La aprobación de este decreto, que destinaba dos millones y medio de pesos de la indemnización para liquidar todos los dividendos atrasados y además reducía permanentemente el rédito al 3\% anual, dio lugar a que se efectuara una nueva conversión de la deuda externa que, en opinión de su autor, fue "uno de los negocios más provechosos que ha hecho la nación desde que conquistó su independencia" (Payno 1852: 12).

Aunque finalmente los tenedores de bonos obtuvieron una parte del dinero de la indemnización como pago por los intereses adeudados, esta cantidad fue mucho menor de la que esperaban recibir y Mackintosh no tuvo ninguna participación en la solución del asunto, es más, la poca ayuda que pudo proporcionar a los agentes enviados por el Comité de Tenedores de Bonos Mexicanos determinó que uno de ellos, Francisco Falconnet, decepcionado con estos resultados, aconsejara a la firma de Baring Brothers retirar la representación que durante tanto tiempo habían tenido Manning y Mackintosh en sus negocios en México y depositarla en la casa de Jecker, Torre y Cía. 
(Platt 1982: 246). Las consecuencias de esta decisión fueron funestas para la firma que, como ya habíamos señalado, realizaba gran parte de sus operaciones de cambio basada en la línea de crédito que tenía abierta con Baring Brothers, además del prestigio y el poder que en el campo financiero le había conferido ser representante de una de las empresas bancarias y comerciales más importantes de la época en el ámbito internacional.

\section{Los problemas}

Pero aun antes de que esto sucediera, la posición de Mackintosh en México se iba haciendo cada vez más difícil. Debido a su participación en las negociaciones de paz y a la influencia que hasta entonces había ejercido en los círculos políticos y financieros del país, estaba seguro de que su casa sería la encargada de llevar a cabo todas las operaciones relacionadas con las transferencias de fondos de la indemnización y los adelantos que sobre ella se pudieran negociar. Además, pretendía recibir el pago de todos los créditos que poseía contra el Gobierno, procedentes de las numerosas especulaciones en que había participado en los últimos años.

Aunque, efectivamente se destinaron $\$ 600.000$ del primer abono de la indemnización para reembolsarle un préstamo que había hecho el año anterior (ver anexo 3) y de esta manera rescatar los cinco millones de pesos en créditos de la deuda interior que mantenía en calidad de hipoteca, ${ }^{52}$ no parece que haya obtenido muchos beneficios más (Romero 1870: 300).

52 Este negocio ha sido interpretado de manera equivocada en varias ocasiones, tanto en algunos artículos publicados en los periódicos de esa época, como en obras recientes. Bárbara Tenenbaum (1985: 116) señala que en 1847 el ministro de Hacienda, Juan Rondero, había dado a Manning y Mackintosh créditos por un valor de cinco millones de pesos, la mayoría consistente en bonos del tabaco, como hipoteca por un préstamo de $\$ 600.000$ en efectivo que debía ser pagado el $1^{\circ}$ de abril de 1848. Como se puede observar en el anexo 3 , estos créditos debía darlos Mackintosh al Gobierno como parte del convenio que había celebrado para la conversión de la deuda y en el contrato hecho con Rondero no hacía más que ofrecer por estos créditos, que todavía no entregaba, cierta cantidad en efectivo. La negativa de Mackintosh a la propuesta del Gobierno de pagarle con fondos provenientes de un arreglo negociado con Béistegui (Romero 1870: 284-285) y el hecho de que no entregara los créditos cuando se le pagó con los fondos de la indemnización, sólo demuestra que Mackintosh no poseía dichos créditos y que realizó el contrato con Rondero confiado en que, a causa de la guerra, el Gobier- 
Tal vez en un principio el Gobierno haya estado dispuesto a permitir que la casa se ocupara de todas estas transacciones, pues de acuerdo a lo que Mackintosh declaró en una de sus reclamaciones posteriores, debía entregar al Gobierno una fuerte suma que había contratado el 20 de junio de 1848, como parte de la indemnización. Supuestamente, había llegado a un acuerdo confidencial con el presidente José Joaquín de Herrera y su gabinete, de que se permitiría a Luis S. Hargous exportar casi dos millones de pesos libres de derechos, sin embargo, el ministro de Relaciones, Mariano Otero, se negó a conceder ese permiso, señalando que el ejecutivo carecía de facultades para otorgar dicha concesión. ${ }^{53}$

La actitud adoptada por Otero en este asunto no se puede interpretar únicamente como producto de la antipatía que profesaba hacia Mackintosh, aunque, indudablemente, este es un factor que se puede percibir con claridad en varios comentarios de su correspondencia. Pero más allá de cuestiones personales, las pretensiones de Mackintosh de obtener un trato preferencial para sus negocios y especulaciones por medio de "acuerdos confidenciales" y sus exageradas expectativas respecto a la parte de la indemnización que debía pasar, de una u otra forma, a sus manos, lo convirtieron en el centro de los ataques de diversos grupos pues, como señala el mismo Otero, en octubre de 1848:

Esta casa cada día se atrae mayor odiosidad por la parte que toma en nuestras cuestiones interiores, por la multitud de negocios de agio que ha hecho y por la arrogancia de su socio principal. En la Cámara de Senadores se han hecho contra ella las acusaciones más serias, y como está mal vista por sus mismos compatriotas, nada se opone a tan violenta animadversión.

no no podría pagarle a tiempo y él quedaría libre de la obligación de conseguir los créditos.

53 La reclamación que Mackintosh presentó al respecto y que asciende a $\$ 1.850 .000$ se origina de no habérsele permitido a Hargous exportar, libre de derechos, esta cantidad que él, en su calidad de agente fiscal del ejército norteamericano, había entregado en efectivo a la casa de Manning y Mackintosh, procedente de lo que tenía en caja dicho ejército al evacuar la ciudad de México. Esta cantidad la necesitaba la casa para entregarla como parte de un contrato hecho con el Gobierno y a cambio entregó a Hargous Brothers letras por la misma cantidad sobre Nueva York (ver anexo 4, reclamación 1). 
Aunque también admite que la culpa de que ejerciera tal influencia la tenían los distintos Gobiernos mexicanos. ${ }^{54}$

Desde luego Mackintosh estaba muy consciente de esta influencia y seguía ejercitándola en todos los ámbitos, pero la situación política se complicaba y sus expectativas de beneficios inmediatos se frustraban ante la falta de apoyo gubernamental. Sin embargo, esto no parecía preocuparle demasiado y de momento no se apreciaban grandes cambios en sus actividades. En 1849 seguía siendo representante de los tenedores de bonos, era socio de la compañía arrendataria del tabaco, de varias casas de moneda y continuaba haciendo transferencias de dinero, respaldado por sus contactos en Inglaterra. Incluso llegó a emprender nuevos negocios pues, en julio de ese año, en unión con sus socios del tabaco, adquirió la Compañía de Minas de Real del Monte. Pero todo esto lo hizo con dinero de otros, confiado en que los problemas de liquidez serían pasajeros y que el Gobierno muy pronto le proporcionaría buena parte de las ganancias proyectadas.

Es por ello que, de acuerdo con las evidencias notariales, su caída resulta tan sorprendente e intempestiva. Se inicia junto con el año, en 1850 , y en unos cuantos días se consuma la venta o la adjudicación de la mayoría de sus propiedades. A sus socios en la compañía arrendataria del tabaco, que eran Miguel Bringas, Juan Antonio Béistegui y Manuel Escandón, reconoció adeudarles \$400.000 que le habían proporcionado a lo largo de 1849 para sus diversos negocios y, el 25 de enero, les vendió su participación en dicha compañía -a la cual declaró no haber aportado nunca capital de sus propios fondos- por $\$ 200.000$, que ellos se adjudicaron como parte del adeudo. ${ }^{55}$

Al día siguiente vendió a los mismos socios las 45 acciones que le pertenecían en la negociación de minas de Real del Monte, por la cantidad de $\$ 33.750$ y señaló que le interesaba recoger inmediatamente esta suma para las atenciones urgentes de su caja. ${ }^{56}$ Ese mismo día, en otro documento notarial, cedió a Béistegui sus acciones y derechos como coarrendatario de la casa de moneda de la ciudad de México, así como los derechos que tenía al estanco del tabaco en Sinaloa, en pago

54 Carta de Mariano Otero a José M. ${ }^{a}$ Luis Mora, 14 de octubre de 1848, en García (1906, VI: 118).

55 ANCM, notario Ramón de la Cueva (1850, f. 51v.).

56 ANCM, notario Ramón de la Cueva (1850, f. 55). 
de las distintas cantidades que le había ido proporcionando y que ascendían a la suma de $\$ 304.601 .^{57}$

Unos días más tarde, el 4 de febrero, vendió a la firma de Agüero González y Cía. su casa en la calle de Capuchinas con sus elegantes muebles, cuadros, candiles, vajillas y, en fin, todo lo que había en ella ${ }^{58}$ y al poco tiempo le vendió también una casa más que poseía en Tacubaya. ${ }^{59}$ Como en muchas ocasiones, los documentos notariales sólo muestran el resultado final de un negocio, no podemos saber qué tipo de transacciones celebró con los socios de la firma Agüero González y Cía., pero unos años más tarde los demandó judicialmente por "las usuras cometidas en diversos negocios" que habían celebrado, así que éstos, para evitarse problemas, decidieron llegar a un arreglo con él y le devolvieron la casa de Tacubaya, que sólo tenía un valor de $\$ 4.000$. $^{60}$

También cedió a sus acreedores su fábrica de papel en Coyoacán, que había comprado el año anterior ${ }^{61}$ y los intereses que tenía en una fábrica textil en Jalapa. ${ }^{62}$ Sólo le quedaron algunas acciones en distintas minas, de las cuales eran especialmente importantes las que poseían él y su hermano Enrique en el Mineral de La Luz, en Guanajuato, que por entonces experimentaba una gran bonanza. Sin embargo, estas acciones se encontraban en litigio desde el momento en que las había adquirido, además de que también tuvieron que ser hipotecadas para conseguir diversos préstamos y un poco más adelante algunas de ellas fueron adjudicadas a sus acreedores.

Llama la atención el hecho de que Mackintosh haya vendido la mayoría de sus propiedades en un periodo tan corto de tiempo y se ha llegado incluso a sugerir que las ventas fueron ficticias y que lo que se buscaba era dar la apariencia de quiebra para que los acreedores no tuvieran manera de cobrar sus adeudos (Tenenbaum 1979: 328). En realidad era todo lo contrario, la mayoría de las ventas eran adjudicaciones por las cantidades que adeudaba a sus socios, quienes habían estado financiándolo durante algún tiempo, hasta que llegó el momen-

57 ANCM, notario Ramón de la Cueva (1850, f. 58).

58 ANCM, notario Ramón de la Cueva (1850, f. 86v., f. 111).

59 ANCM, notario Ramón de la Cueva (1850, f. 103).

60 ANCM, notario Pablo Sánchez (1857, f. 176) y notario José Villela (1857, f. 131).

61 ANCM, notario Ramón de la Cueva (1850, f. 104v.).

62 ANCM, notario Ramón de la Cueva (1850,f. 190). 
to en que su situación se volvió insostenible y ellos, desde luego, buscaron la manera de cobrar sus créditos antes de que se declarara la insolvencia, pues entonces se integraría una junta de acreedores y se asegurarían todos los bienes del deudor. En el caso de las ventas hechas a Agüero González, parece que aquí sí se trató de un esfuerzo desesperado de Mackintosh por obtener dinero para pagar a otros de sus acreedores y poder salvar el crédito de su casa comercial. En una sociedad en la que las relaciones comerciales se basaban en gran medida en la confianza que se tenía en la solvencia de una empresa -y más para una casa como la de Manning y Mackintosh que manejaba la mayoría de sus operaciones a partir de créditos, letras de cambio, libranzas y bonos y no en dinero en efectivo- la opinión que los demás tuvieran sobre su capacidad de pago era fundamental y podía determinar en un momento dado la quiebra de una casa comercial, aunque ésta contara con muchas propiedades e inversiones importantes, pero no con dinero en efectivo.

De hecho, el mismo Mackintosh señala esta falta de confianza como uno de los motivos principales de su quiebra al declarar:

La situación aflictiva del erario nacional, la paralización que el comercio experimenta hace más de dos años y alguna que otra voz esparcida en el comercio con malicia o sin ella contra el crédito de nuestra casa, nos condujo a una dolorosa crisis. ${ }^{63}$

Sólo que esta última declaración acerca de los rumores esparcidos contra el crédito de su casa resulta bastante tramposa, ya que no se trataba de simples rumores sino de hechos bastante evidentes, que habían comenzado desde tiempo atrás, pero cuyas consecuencias había logrado retrasar durante algún tiempo, en detrimento de sus acreedores. Este es el caso, por ejemplo, del Banco Colonial de Inglaterra, contra el cual la casa había girado varias letras, desde octubre del año anterior, sin haber hecho el envío de fondos a que estaba comprometida. El Banco había estado pagando puntualmente las letras "por obsequiar la firma de la casa giradora", sin embargo, ya sumaban 31 letras, por un total de $\$ 281.726,77$, sin que la casa de Manning y Mackintosh hubiera hecho un solo pago, por lo que el Banco se vio obligado a enviar un representante con el objeto de cobrar el adeudo. Cabe men-

63 AGN, Ramo de Bienes Nacionales (Legajo 81, Solicitud de esperas al Venerable Clero, 19 de diciembre de 1851). 
cionar que para 1856, última fecha en que encontramos noticias sobre este asunto, sólo se había logrado el pago de una mínima parte de esta deuda. ${ }^{64}$

Pese a todo, sus esfuerzos por conservar la buena imagen de la casa no tuvieron mucho éxito, pues ya para el mes de mayo Mariano Otero informa a su corresponsal de varios detalles interesantes en relación con esta cuestión.

Las cuentas publicadas en esa [Londres], respectivamente por los acreedores y la agencia, prueban de una manera evidente que la casa de Manning y Makintosh (sic) no remitía los fondos con la oportunidad debida, sino que los detenía para emplearlos probablemente en la multitud de especulaciones locas que emprendía y que han llevado a su término a esa casa de funesto recuerdo para México. Así, por ejemplo, hace un año que tomó 500.000 pesos de los acreedores para prestarlos al Gobierno con $2 \%$ hasta que se recibiera el dinero de la indemnización, y últimamente detuvo en su poder bastante tiempo lo que recibió del tabaco. ${ }^{65}$

En este caso las noticias proporcionadas por Otero se confirman más tarde, a través de una escritura de hipoteca en la que se señala que la casa adeuda a los tenedores de bonos mexicanos en Londres la cantidad de $\$ 254.538$ y que el apoderado de estos, Francisco Falconnet, después de varias conversaciones con Mackintosh, decidió llegar a un acuerdo extrajudicial para no perjudicarlo. ${ }^{66}$

A juzgar por el siguiente comentario, Otero se encontraba perfectamente enterado de todos los pormenores relacionados con la situación financiera de la firma, pues señala:

Por lo demás, si dicha casa debe algo a los acreedores, su pago será imposible, porque ha enajenado cuanto tenía, sin quedarle ya más que dos malas casas de moneda y algunas acciones en minas y pleitos. Hasta ahora sus acreedores se habían estado conformando con malos arreglos por no perderlo todo; pero como para los últimos no son posibles ni malos arreglos, lo tienen ya embargado por más de cien mil pesos; y aunque él está ocurriendo a entrampar los pleitos y a alegar que pagaba por los capitales un interés usurario, esto mismo le acaba de quitar todo crédito.

64 ANCM, protocolo 426 (1850, f. 609).

65 Carta de Mariano Otero a José Ma. Luis Mora, 14 de mayo de 1850, en García (1906, VI: 162).

66 ANCM, notario Manuel Orihuela (1852, f. 203). Falconnet fue uno de los que se vio beneficiado con la quiebra de Mackintosh, pues el acuerdo al que llegaron no fue sólo por "su deseo de no perjudicarlo", sino porque le permitió participar, de manera particular, en el negocio de la colonización de Tamaulipas (ver nota 49). 
Salvo la bonanza de una mina o la vuelta de Santa Anna no creo que el hombre tenga remedio. ${ }^{67}$

Por desgracia para Mackintosh, las bonanzas ocurrieron en las minas donde ya no tenía ninguna participación, como fue el caso de Real del Monte, o donde la propiedad estaba en litigio y, además, hipotecada, como ocurría en el caso del Mineral de La Luz, así que dichas bonanzas sólo beneficiaron a sus antiguos socios o a algunos de sus acreedores. La vuelta de Santa Anna, en 1853, no parece haberle sido de ninguna utilidad, pues ya para entonces no tenía nada que pudiera interesar al general a cambio de su ayuda.

Pero a pesar de la crítica situación en que se encontraba para 1850 , Mackintosh todavía tenía grandes esperanzas de recuperarse, aunque ya no ejercía la misma influencia en las esferas gubernamentales, aún logró que el ministro de Hacienda, Francisco Elorriaga, enviara en el mes de febrero una solicitud al Congreso para que se pagara a Mackintosh lo que el Gobierno le debía, a cambio de lo cual él devolvería las casas de moneda de Guadalupe y Calvo y Culiacán. Esta pretensión causó gran indignación entre varias personas y los periódicos comenzaron a lanzar fuertes ataques contra él y contra Elorriaga, a quien los editorialistas preguntaban si acaso ignoraba que, de los numerosos contratos que Mackintosh había hecho con el Gobierno, los únicos que no producían ganancias eran precisamente los de esas dos casas de moneda. ${ }^{68} \mathrm{~A}$ raíz de esta solicitud, salieron a relucir las irregularidades que Mackintosh había cometido en varios de los negocios por los que ahora pretendía reclamar un pago. Fueron tantas las críticas que recibió que tuvo que desistir de su intento, sin embargo, todavía aparecieron algunas editoriales en que se hablaba de sus negocios fraudulentos, principalmente del relacionado con los cinco millones de pesos en créditos y el de la venta de los vapores en La Habana. ${ }^{69}$

Seguramente por este motivo decidió posponer sus reclamaciones y no fue hasta 1858 cuando, después de solicitar la ayuda del Gobierno británico, consiguió que se nombrara una comisión que se encarga-

67 Carta de Mariano Otero a José M. ${ }^{a}$ Luis Mora, 14 de mayo de 1850, en García (1906, VI: 162-163).

68 El Siglo Diez y Nueve, 9 de febrero de 1850.

69 Ibid., 24 y 28 de febrero de 1850. 
ra de revisar todas sus reclamaciones, ${ }^{70}$ las cuales se encuentran resumidas en el anexo 4.

Por lo visto, en este periodo Mackintosh dispuso de tiempo suficiente para incluir en sus demandas todo lo que se le iba ocurriendo, pues de acuerdo con un documento fechado en septiembre de 1850 el Gobierno le adeudaba la cantidad de $\$ 2.076 .208,2,2^{71}$ y todavía en 1851 declara a sus acreedores que entre sus activos se encontraban dos millones de pesos en créditos contra el Gobierno, de manera que resulta bastante extraña la forma en que se incrementó esta cantidad en los siguientes seis años, precisamente cuando Mackintosh ya no estaba en condiciones de realizar ningún negocio de este tipo.

En la solicitud de esperas que había presentado a sus acreedores a fines de 1851, el encargado de resolver sobre los adeudos que tenía pendientes con la Iglesia, señala en su informe que, de acuerdo con los datos que le habían proporcionado algunos de los acreedores de Mackintosh, su crédito pasivo ascendía a dos millones y medio de pesos, mientras que los fondos para pagar excedían de cinco millones. Éstos consistían en la propiedad de algunas acciones en diversas minas, en la de terrenos en algunos estados fronterizos o litorales de la República, en acciones en las casas de moneda de Guadalupe y Calvo

70 Aunque en 1855 el Gobierno consideró la conveniencia de designar un comisionado especial para que comenzara a analizar dichas reclamaciones, el tiempo pasaba $\sin$ que se adelantara nada sobre este asunto. Ante la falta de resultados, los abogados de Mackintosh solicitan en 1857 la intervención del Gobierno británico, el cual se limita a sugerir la formación de la comisión especial, que ya había sido propuesta por el Gobierno mexicano, para que se investigara la validez de las reclamaciones. Al parecer, este intento tampoco obtuvo ningún resultado, así que el Gobierno británico tiene que hacer una segunda recomendación en este sentido. Por fin, en 1858 se nombra una comisión encabezada por Ignacio Piquero, la cual tiene que enfrentar numerosos obstáculos para obtener la información necesaria, pues en las oficinas gubernamentales nadie parece dispuesto a cooperar en ese sentido, y el mismo Mackintosh declara que la mayoría de los comprobantes los había perdido en las oficinas liquidatarias o había tenido que venderlos en momentos de grandes apuros. Finalmente se logra emitir un dictamen sobre ocho de las trece reclamaciones presentadas, disminuyendo bastante las cantidades señaladas por Mackintosh. Sin embargo, el tiempo sigue pasando sin que se consiga, a pesar de los esfuerzos de Mackintosh y posteriormente de sus herederos, que el Gobierno mexicano haga nada respecto a estas reclamaciones, por lo menos hasta 1870 (Romero 1870: 927-939).

71 BLAC, Manning and Mackintosh Papers, Serie 1, Correspondencia, 30 de septiembre de 1850 . 
y Culiacán y en créditos contra el Gobierno y contra algunos particulares. $^{72}$

El hecho de que sus deudas ascendieran a dos millones y medio de pesos para finales de 1851, significa que la mayoría de estos créditos se quedaron sin pagar, pues para este momento ya había vendido casi todas sus propiedades y el resto, incluidas la mayoría de las que se señalan al promotor eclesiástico como garantía, ya están hipotecadas a otros acreedores. Aunque se trata de un tema muy extenso que no vamos a tratar aquí, es importante señalar que la casa se condujo de manera fraudulenta en todo lo relacionado con la suspensión de pagos y las esperas que pidió a sus acreedores, pues a pesar de que algunas de las reclamaciones fueron llevadas incluso ante diversos juzgados, Mackintosh utilizó toda clase de argucias y nunca declaró formalmente la quiebra. Hipotecó en varias ocasiones y a distintos acreedores las mismas propiedades, algunas de las cuales ya ni siquiera le pertenecían, o vendió propiedades que ya se encontraban hipotecadas. En fin, su actuación en este sentido correspondió al mismo estilo con que acostumbraba a hacer sus negocios y con el cual hizo más tarde reclamaciones totalmente desproporcionadas, incluso algunas de ellas ilegales, al Gobierno.

Sólo que, en el caso del Gobierno, dichas reclamaciones no tuvieron ningún efecto en la práctica, mientras que para muchos de los acreedores, la falta de pago les ocasionó, además de las pérdidas proporcionales al monto de sus créditos, numerosos disgustos y nuevos gastos al tener que recurrir a los tribunales a entablar interminables litigios.

Desde luego esta casa no fue la única que se enfrentó a la bancarrota debido a la situación conflictiva del comercio o de las finanzas mexicanas, pero sí protagonizó una de las quiebras más espectaculares de la época por la magnitud de los negocios en que estuvo involucrada y por las fabulosas reclamaciones que tanto Mackintosh como sus herederos continuaron haciendo al Gobierno. Como ya hemos visto en varios de los casos analizados, la mayoría de estas reclamaciones no procedían de cantidades que se le adeudaran realmente, sino que se trataba de indemnizaciones solicitadas por las ganancias que había

72 AGN, Bienes Nacionales, Legajo 81, Dictamen del Lic. Sagaseta sobre la solicitud de esperas, 30 de enero de 1852 . 
dejado de obtener al no llevarse a cabo algunos de los negocios en la forma en que él los tenía proyectados.

Una de las reclamaciones más representativas en este sentido, es la relacionada con la conversión de la deuda inglesa, ya que fue una de las primeras que presentó al Gobierno, aun antes de su quiebra, y en ella pedía casi dos millones de pesos de indemnización por los daños y perjuicios que había sufrido a causa del escándalo provocado en Londres por la demora en la aprobación de la conversión de 1846 que, como ya hemos visto con bastante detalle, ocasionó una baja considerable en el valor de los bonos y él tuvo que vender el sobrante a un precio menor del que había calculado. Al ser consultado sobre esta reclamación, Manuel Payno señala:

Confieso que me sorprendió no poco esta reclamación [...] porque si en negocios de semejante naturaleza el Gobierno fuera a hacerse responsable de la alta y baja de los papeles de la deuda pública, pocas serían todas las rentas para pagar las indemnizaciones que se pidieran (Payno 1851: 44-46).

Seguramente se habría sorprendido aún más si hubiera conocido el resto de las reclamaciones, pues además de los casos que ya hemos señalado, existen muchos otros en los que ya no tenía ningún derecho a reclamar, pues había vendido o hipotecado los créditos a una tercera persona.

El hecho de que las autoridades mexicanas no hayan hecho observaciones sobre lo desproporcionado de estas reclamaciones, probablemente se deba a que la situación política era tan complicada en esa época, que no existía ni la voluntad ni la posibilidad de analizar por el momento dichos reclamos, así que dejaron que las cosas se prolongaran sin tomar ninguna medida para solucionarlas.

Desde luego, para Mackintosh el asunto era de vital importancia, pues el obtener el pago de una parte, aunque fuera mínima, de estas reclamaciones, habría significado un gran alivio para salir de la situación desesperada en que se encontraba. Las numerosas tentativas que él y sus herederos realizaron en este sentido, muestran que para ellos la solución a sus demandas era algo factible, en lo que gastaron mucho dinero e invirtieron gran cantidad de tiempo y esfuerzo sin ningún resultado aparente.

Mackintosh muere en 1861 sin haber visto resuelta ninguna de sus reclamaciones al Gobierno mexicano, pero proporcionando a los his- 
toriadores una prueba de que las consecuencias podían ser fatales cuando se rompía el difícil equilibrio que se debía conservar en lo relativo a las especulaciones con la deuda pública interna.

\section{Bibliografía}

Bazant, Jan (1968): Historia de la deuda exterior de México (1823-1946). México, D.F.: El Colegio de México.

Carballo, Alfonso (1998): "La Conversión de 1846 de la deuda inglesa y la guerra de intervención estadounidense". En: Estudios, 14, 50-51, pp. 27-58.

Dublán, Manuel (1888): Informe que el Ministro de Hacienda ... presenta al Congreso de los Estados-Unidos Mexicanos sobre el empréstito contraido en Europa de $£$ 10.500.000. México, D.F.: Imprenta del Gobierno Federal.

Dublán, Manuel/Lozano, José María (1876-1902): Legislación mexicana ó colección completa de las disposiciones legislativas expedidas desde la Independencia de la República. 31 vols., México, D.F.: Imprenta del Comercio,

García, Genaro (ed.) (1906): "Papeles y obras sueltas del Dr. Mora”. En: García, Genaro (ed.): Documentos inéditos ó muy raros para la historia de México, vol. 6., México, D.F.: Ch. Bouret.

Jiménez Codinach, Guadalupe (1991): La Gran Bretaña y la independencia de México, 1808-1821. México, D.F.: Fondo de Cultura Económica.

Liehr, Reinhard (1983): "La deuda exterior de México y los 'merchant bankers' británicos, 1821-1860". En: Ibero-Amerikanisches Archiv, 9, 3-4, pp. 415-439.

Meyer, Rosa María (1987): "Los ingleses en México, la casa Manning y Mackintosh (1824-1852)". En: Historias, 16, pp. 57-71.

- (1999): "Los empresarios y el crédito en el México Independiente". En: Meyer, Rosa María (ed.): Identidad y prácticas de los grupos de poder en México, siglos XVII-XIX. México, D.F.: INAH, pp. 227-256.

- (2000): "La quiebra de la firma Manning y Mackintosh". En: Altamirano, Graciella (ed.): Prestigio, riqueza y poder. Las elites en México, 1821-1940. México, D.F.: Instituto Mora, pp. 87-114.

Payno, Manuel (1851): Reseña sobre el estado de los principales ramos de la Hacienda Pública. México, D.F.: Ignacio Cumplido.

- (1852): Memoria en la que da cuenta al público de su manejo en el desempeño del Ministerio de Hacienda y de las comisiones que le confió el Supremo Gobierno en Inglaterra. México, D.F.: Ignacio Cumplido.

- (1862): México y sus cuestiones financieras con la Inglaterra, la España y la Francia. México, D.F.: Ignacio Cumplido.

Platt, D. C. M. (1982): "Finanzas británicas en México (1821-1867)". En: Historia Mexicana, 32, 2, pp. 226-261.

Ramírez, José Fernando (1853): Memorias, negociaciones y documentos, para servir a la historia de las diferencias que han suscitado entre México y los EstadosUnidos los tenedores del antiguo privilegio, concedido para la comunicación de 
los mares Atlántico y Pacifico por el istmo de Tehuantepec. México, D.F.: Ignacio Cumplido.

Romero, Matías (1870): Memoria de Hacienda y Crédito Público. México, D.F.: Imprenta del Gobierno.

Rosa, Luis de la (1848): Esta Memoria sirve de apéndice a la liquidación general de la deuda contraida por la República en el Exterior, formada por D. Lucas Alamán [...] en 1845. México, D.F.: Vicente García Torres.

Suárez Argüello, Ana Rosa (2003): La batalla por Tehuantepec. El peso de los intereses privados en la relación México-Estados Unidos, 1848-1854. México, D.F.: Secretaría de Relaciones Exteriores.

Tenenbaum, Barbara (1979): "Merchants, Money and Mischief. The British in Mexico, 1821-1862". En: The Americas, 35, 3, pp. 317-339.

- (1985): México en la época de los agiotistas, 182I-1857. México, D.F.: Fondo de Cultura Económica.

Terrazas y Basante, Marcela (2000): Inversiones, especulación y diplomacia. Las relaciones entre México y los Estados Unidos durante la dictadura santannista. México, D.F.: Universidad Nacional Autónoma de México.

Velasco, Cuauhtémoc, et al. (1988): Estado y minería en México (1767-1910). México, D.F.: Fondo de Cultura Económica-SEMIP.

Walker, David W. (1991): Parentesco, negocios y política. La familia Martínez del Río en México, 1823-1867. México, D.F.: Alianza.

Zavala, Lorenzo de (1829): Razón de los préstamos que ha negociado el Supremo Gobierno de la Federación [...]. México, D.F.: Imprenta del Correo. 


\section{Anexo 1: \\ Resumen de las propuestas presentadas para la conversión de la deuda exterior}

\section{Primera propuesta (29 de abril de 1845)}

Crear en Londres un nuevo fondo consolidado por valor de cuatro millones de libras. Este nuevo fondo no incluiría todos los bonos en que estaba dividida la deuda sino únicamente los llamados diferidos y las debenturas, que en ese momento ascendían a $£ 5.123 .096$. Este nuevo fondo se amortizaría en un plazo de 80 años, ganando un $5 \%$ de interés anual y para su amortización el gobierno destinaría $\$ 83.333,00$ mensuales provenientes de la renta del tabaco, la cual quedaría hipotecada especialmente para el pago de este nuevo fondo. Manning y Mackintosh se comprometían a cambiar todos los viejos bonos de este tipo, que se encontraban en manos de los tenedores, de acuerdo con su precio en el mercado y se quedarían con el sobrante de los $£ 4.000 .000$ de nuevos bonos.

A cambio de esta operación, la casa se comprometía a entregar al gobierno cinco millones de pesos en bonos del $26 \%$ de la deuda interior y dos millones de pesos en efectivo. Los créditos deberían entregarse en agosto de 1846 y el efectivo en dos exhibiciones mensuales de $\$ 250.000$ cada una, en mayo y junio de 1845 y el resto en abonos mensuales a partir de octubre del mismo año. Entre las condiciones establecidas se encontraba la de que Manning y Mackintosh se reservaban el derecho de ratificar el contrato en un término de cuatro meses y en caso de que no lo hicieran el gobierno debería devolverles los $\$ 500.000$ de los abonos entregados en mayo y junio.

Al conocerse este contrato en Londres, la casa de J. Schneider y Cía., que había sido nombrada como agente del gobierno mexicano ante los tenedores de bonos, en sustitución de la casa Lizardi, informó al ministro plenipotenciario de México en esa ciudad, Tomás Murphy, que el convenio era impracticable, pues los tenedores de bonos no tenían ninguna obligación de entregar sus títulos -que era una de las condiciones del convenio-, además de que sería imposible que con los cuatro millones de libras del nuevo fondo se pudiera realizar la compra de todos los bonos diferidos y las debenturas.

Cuando estas noticias llegaron a México, en septiembre de 1845, Manning y Mackintosh se negaron a ratificar el convenio y pidieron la devolución de los $\$ 500.000$ que ya habían entregado a cuenta de él.

\section{Segunda propuesta (29 de septiembre de 1845 )}

Las modificaciones más importantes respecto a la propuesta anterior consistían en que se incrementaba el fondo consolidado a $£ 4.200 .000$, fijándose la conversión de los bonos diferidos y las debenturas al $40 \%$ de su valor nominal. Para la amortización del capital y sus intereses, el gobierno aumentaba a $\$ 108.333$ la cuota mensual proveniente de la renta del tabaco. Por su parte, 
la casa de Manning y Mackintosh ofrecía para la compra de este nuevo fondo las mismas condiciones que en la propuesta anterior.

Este nuevo arreglo tampoco pudo llevarse a cabo, porque en el contrato celebrado entre el gobierno y la casa de Manning y Mackintosh una de las condiciones establecía que no se podría hacer la entrega de los nuevos bonos hasta que la conversión estuviera asegurada.

Ante este nuevo contratiempo, Schneider recomendó a Murphy que antes de proponer nuevas bases para la conversión se tuviera una reunión con los tenedores de bonos para lograr un acuerdo sobre los puntos pendientes. A pesar de que el gobierno mexicano trató de allanar los obstáculos formales, los tenedores pusieron como condición para llegar a una negociación que se incluyera en ella el pago de todos los intereses atrasados desde octubre de 1844, mediante una capitalización.

Como era de esperarse, Manning y Mackintosh optaron por no ratificar el convenio y pidieron nuevamente la devolución de los $\$ 500.000$ que habían adelantado. El gobierno, que no contaba con recursos para hacer la devolución y que necesitaba urgentemente conseguir nuevos fondos, insistió en llegar a un nuevo arreglo.

\section{Tercera propuesta ( 5 de marzo de 1846$)$}

En esta ocasión el fondo consolidado se incrementaba a $£ 4.650 .000$, con los cuales se realizaría la conversión de los bonos diferidos y las debenturas al $40 \%$ de su valor y se capitalizarían los intereses adeudados, que ascendían a $£ 559.169$. A cambio de esto la casa de Manning y Mackintosh ofrecía en efectivo $\$ 1.600 .000$, de los cuales $\$ 1.100 .000$ se entregarían en partidas parciales, mientras que los otros $\$ 500.000$ se abonarían a cuenta de lo que ya habían adelantado al gobierno desde el año anterior. También se introducía un cambio en la clase de créditos que se entregarían al gobierno, ahora ofrecían $\$ 1.500 .000$ en bonos del tabaco, $\$ 500.000$ en bonos del $26 \%$, $\$ 2.500 .000$ en créditos reconocidos que causaran réditos y $\$ 500.000$ en créditos reconocidos que no los causaran.

Las nuevas propuestas fueron enviadas a Murphy junto con una autorización para remover cualquier obstáculo que se presentara. En una reunión celebrada el 18 de mayo, los tenedores rechazaron esta nueva propuesta, argumentando que en ella se dejaba fuera de la conversión a los bonos activos, que estaban garantizados con el $20 \%$ de los productos de las aduanas de

73 Aquí hay una discrepancia entre lo que señala Carballo, quien dice que Manning y Mackintosh ofrecieron lo mismo que en la propuesta anterior, mientras que Payno afirma que en esta ocasión la casa ofreció cuatro millones de pesos en créditos, dos en bonos del tabaco y dos en bonos del $26 \%$. Seguramente esta diferencia se debe a que su información está tomada de fuentes distintas. Tampoco concuerdan todos los datos de Luis de la Rosa en lo relativo a las condiciones de los contratos, así que en cada caso se han consignado los datos que parecen más acordes con el desarrollo de las negociaciones. 
Veracruz y Tampico, así como por los derechos de exportación de plata por los puertos del Pacífico, mientras que los nuevos bonos quedaban garantizados por la renta del tabaco.

Frente a este nuevo tropiezo, Murphy, Schneider y Manuel Escandón quien había llegado a Londres para ayudar en las negociaciones-se reunieron al día siguiente con el vicepresidente del Comité de Bonos Hispanoamericanos para analizar la situación. Considerando que lo que realmente solicitaban los tenedores de bonos era un trato equitativo para los tres tipos de bonos (activos, diferidos y debenturas), Murphy propuso un nuevo arreglo, que finalmente fue aprobado por los tenedores de bonos en una junta general celebrada el 4 de junio.

\section{Conversión de 1846 (4 de junio de 1846)}

Con este nombre fue conocida la propuesta definitiva, hecha por Murphy y aceptada por los tenedores, que consistía en crear un fondo de $£ 10.241 .650$ que contemplara la conversión de los bonos activos, los diferidos y las debenturas, además de los intereses atrasados. Los bonos activos se comprarían al $90 \%$ de su valor y los diferidos y las debenturas al $60 \%$. Como recompensa por comprar los bonos activos al 90\%, los tenedores renunciaban al pago de los intereses atrasados y diferían el pago del primer dividendo de los nuevos bonos hasta el 1 de julio. Los nuevos bonos ganarían un interés del $5 \%$ anual y para su pago, así como para la amortización del capital, el gobierno destinaría $\$ 117.708,33$ mensuales de la renta del tabaco, además del $20 \%$ de las recaudaciones aduanales de Veracruz y Tampico y todos los derechos de exportación de plata por los puertos del Pacífico.

El remanente de este nuevo fondo, una vez hecho el cambio de los bonos antiguos en la proporción acordada, era de $£ 2.135 .318$, que se entregarían a la casa de Manning y Mackintosh bajo las condiciones que ésta había señalado en su propuesta anterior.

Fuentes: Carballo (1998: 27-58); Payno (1862: 12-15); Rosa (1848: 5-6); Bazant (1968: 64-66). 


\section{Anexo 2: \\ Ganancias calculadas para la casa de Manning y Mackintosh en cada una de las propuestas}

\section{Primera propuesta (29 de abril de 1845)}

Aquí la única ganancia que se puede calcular de manera más o menos precisa es la que obtendrían de que el gobierno mexicano les vendiera el nuevo fondo consolidado a cambio de dos millones de pesos en efectivo y cinco millones de pesos en bonos del $26 \%$, que calculados al $25 \%$, que era su valor en el mercado, ${ }^{74}$ les costarían $\$ 1.250 .000$. O sea, que sólo con la introducción de los bonos a su valor nominal ganarían $\$ 3.750 .000$.

Como no existe información sobre cuánto pensaban pagar por los bonos que se iban a convertir, no es posible hacer una estimación precisa de las ganancias que esperaban obtener por este concepto, sin embargo, podemos intentar algunas aproximaciones. Si tomamos en cuenta que el comprar el fondo de los $£ 4.000 .000$ sólo les costaría \$3.250.000 (procedentes de los dos millones en efectivo y los $\$ 1.250 .000$ del valor real de los créditos) y que esta suma equivaldría a $£ 650.000$, ya que normalmente se le asignaba un valor de cinco pesos por libra, entonces tendrían $£ 3.350 .000$ en nuevos bonos para convertir un total de $£ 5.123 .096$ a que ascendían todos los bonos diferidos y las debenturas. Con esta cantidad podrían adquirirlos hasta en un $65 \%$ de su valor nominal, estimación demasiado elevada si se toma en cuenta que los más caros, que eran los diferidos, se cotizaban en el mercado por debajo del $17 \%{ }^{7}$

Así que, suponiendo que pagaran por los viejos bonos un $35 \%$, que era un poco más del doble de su valor en el mercado, gastarían en ello $£ 1.793 .083$, lo que les dejaría una ganancia aproximada de $£ 1.556 .917$-un poco más del $30 \%$ - que equivaldría a $\$ 7.784 .585$ en nuevos bonos.

\section{Segunda propuesta (29 de septiembre de 1845)}

Aquí el gobierno aumentaba el fondo de consolidación de $£ 4.000 .000$ a $£ 4.200 .000$. Si consideramos que ya se le asignaba un valor de $40 \%$ a los $£ 5.123 .096$ existentes en bonos diferidos y debenturas, la conversión se llevaría a cabo con $£ 2.049 .238,8 \mathrm{sh}^{76}$ y el total de los bonos que quedarían a Manning y Mackintosh sería de $£ 2.150 .761,12 \mathrm{sh}$, a cambio de los cuales la casa ofrecía al gobierno los mismos $£ 650.000$ que en el convenio anterior. Esto dejaba en manos de la casa contratista una ganancia de $£ 1.500 .761,12 \mathrm{sh}$, que equivaldrían a $\$ 7.503 .808$ en nuevos bonos.

74 Los datos sobre el valor que tenían los bonos de la deuda interior en distintos momentos están tomados de Walker (1991: 242, 251).

75 Payno (1862: 60).

76 sh (shillings). En esta época una libra equivalía a 20 chelines. 


\section{Tercera propuesta ( 5 de marzo de 1846)}

En esta ocasión el gobierno aumenta el fondo consolidado a $£ 4.650 .000$, con los cuales habría que cubrir los $£ 2.049 .238$, 8sh de los bonos diferidos y debenturas al $40 \%$ de su valor y todos los intereses vencidos, que ascendían a $£ 559.169$, lo que daba un total de $£ 2.608 .407$ que se debían dar a los tenedores en nuevos bonos.

El resto del fondo, o sean $£ 2.041 .592,12$ sh se vendían a la casa contratante a cambio de $\$ 1.600 .000$ en efectivo, $\$ 2.000 .000$ en bonos del tabaco y del $26 \%$, que para entonces sólo valían $18 \%$ en el mercado, o sea $\$ 360.000$ y los tres millones de créditos restantes que, calculados al $8 \%$ de su valor $^{77}$ ascendían a $\$ 240.000$. Lo que haría un total de $\$ 2.200 .000$ equivalentes a $£ 440.000$. La utilidad que se obtendría en esta ocasión sería de $£ 1.601 .592 .12 \mathrm{sh}$, que en pesos representarían 8.007.963 en bonos del nuevo fondo.

\section{Conversión de 1846 (4 de junio de 1846)}

Se crea un fondo por $£ 10.241 .650$, con el cual se amortizarían $£ 5.591 .650$ de bonos activos, que al $90 \%$ de su valor ascendían a $£ 5.032 .475$, además de $£ 5.123 .096$ de bonos diferidos y debenturas, que al $60 \%$ de su valor equivalían a £ 3.073.857, todo lo cual sumaba $£$ 8.106.332. Los $£ 2.135 .318$ que sobraban de este fondo se vendían a la casa contratista en las mismas $£ 440.000$ que en la propuesta anterior, pues no existe ningún indicio de que en ese momento la casa hubiera modificado sus condiciones. Esto significa que la utilidad que obtenía en esta ocasión era aún mayor que con la última propuesta, pues ascendía a $£ 1.695 .318$, lo que equivalía a $\$ 8.476 .590$ en bonos del nuevo fondo. Sin embargo, ellos en diversas ocasiones señalan que en este contrato tuvieron una pérdida de $£ 46.635$ a causa de la dispensa del pago de dividendos que obtuvo el gobierno.

De las ganancias calculadas en cada una de estas propuestas se deben descontar los gastos ocasionados por la emisión de los nuevos bonos, las comisiones de los agentes y todas las demás que implicara la conversión.

También es importante señalar que estas ganancias las recibirían en bonos del nuevo fondo, por lo cual las cantidades aquí señaladas disminuirían considerablemente, además de que dependerían de la fluctuación en el valor de los bonos.

77 Este dato está tomado de varias escrituras de compra de esta clase de créditos a la Iglesia, por ejemplo ANCM, notario Ramón de la Cueva (1848, f. 1074v.). 


\section{Anexo 3: \\ Contrato celebrado por Manning y Mackintosh con el gobierno el 19 de julio de 1847}

En el plan de conversión de la deuda exterior propuesto por Murphy en 1846, que fue aceptado por los tenedores de bonos y finalmente reconocido por el gobierno mexicano, no se señalan específicamente los compromisos adquiridos por la casa de Manning y Mackintosh con el gobierno, pero como se indica en el anexo 2, se supone que serían los mismos acordados en la tercera propuesta de conversión, hecha el 5 de marzo de 1846.

Pero en este nuevo contrato la casa introduce modificaciones importantes al imponer las siguientes condiciones:

$1^{\text {a }}$. Que se pase una nota al ministro plenipotenciario de S.M.B. cerca del gobierno de México manifestándole que se ha aprobado la conversión de la deuda exterior en todas sus partes, según lo acordado por el ministro plenipotenciario de la República en Londres con los tenedores de bonos, en junta celebrada en 4 de junio de 1846.

$2^{a}$. La casa contratante se obliga a entregar en la Tesorería general $\$ 600.000$ del modo siguiente: $\$ 400.000$ en dinero efectivo en los plazos que acordarán con el ministro de Hacienda; $\$ 58.000$ en letras de la casa de los Sres. Schneider y Cía., por igual cantidad que había suplido a las Legaciones y el resto en el valor de unos certificados que Manning y Mackintosh tienen sobre los derechos de las conductas de la República, bajo el concepto de que si dichas cantidades no cubren la referida suma de $\$ 600.000$, ésta se completara con libramientos de la Casa de Moneda de México de 1846 o con otra clase de papel procedente de dinero en efectivo.

$3^{a}$. Manning y Mackintosh retendrán en su poder los cinco millones de créditos contra el gobierno, que debían entregar conforme al contrato de conversión, hasta el 1 de abril de 1848, y si en esa fecha el gobierno de la República les paga en efectivo los $\$ 600.000$ expresados, entregarán los créditos en las cantidades y clases estipuladas en el contrato; pero en caso contrario quedarán libres de toda obligación y el gobierno también lo estará de la devolución del dinero.

$4^{\mathrm{a}}$. Se abonará a la casa de Manning y Mackintosh, por la utilidad de cien mil y pico de libras que ha utilizado la República en la dispensa del pago de dividendos, con perjuicio del contratista, la cantidad de $£ 46.635^{78}$ a que montó aquél, expidiéndose por igual importe, al cambio de 44 peniques por peso, un certificado de la Tesorería general, como de entero

78 Aquí hay una discrepancia entre la cantidad señalada por Luis de la Rosa y la de otras fuentes consultadas. Payno (1862: 38 anexos) señala la cantidad de $£ 45.635$, Carballo (1998: 47), citando a Murphy, señala que la cantidad que había perdido la casa contratista era de $£ 46.085$, y es esta misma suma la que aparece en las reclamaciones presentadas en 1857 por dicha casa (Romero 1870: 928). 
hecho en dinero en efectivo, que se recibirá también como tal en cualquier contrato pendiente o que se haga por la casa en lo futuro; entendiéndose que dicho certificado no puede aplicarse a ninguna suma que se haya remitido a Londres para cubrir dividendos.

$5^{\text {a }}$. El monto total de las cantidades que se hallaban en las aduanas marítimas para el pago de dividendos y que fueron ocupadas por el gobierno en virtud del decreto de 2 de mayo de 1846, se reintegrará con permisos de algodón en rama despepitado, fijándose desde luego el precio de 6ps. 6rs. el quintal, por único derecho o contribución, sea de la naturaleza que fuere y bajo el concepto de que si en lo sucesivo se fijasen los permisos particulares o los derechos para el comercio en general de la República de dicho algodón en rama, a menor precio que los 6 ps. 6rs. el quintal, la casa de Manning y Mackintosh gozará de ese beneficio en representación de los tenedores de bonos.

$6^{\text {a }}$. Se expedirán inmediatamente y sin demora todas las órdenes que requieran los contratos celebrados en 9 de octubre de 1845 y 5 de marzo de 1846, e igualmente las de los derechos de algodón.

\section{Las ganancias}

Aunque en el contrato no se señala nada acerca de la cantidad de $\$ 1.100 .000$ que la casa debía dar en dinero en efectivo, según las condiciones pactadas con anterioridad, el hecho de que el gobierno aceptara los contratos de 9 de octubre de 1845 y 5 de marzo de 1846 (que también vienen detallados en la Memoria de Luis de la Rosa y por los cuales el gobierno reconocía un adeudo de un millón de pesos, cuando en realidad sólo había recibido $\$ 576.800$, puesto que un $46 \%$ del monto correspondía a papeles de la deuda pública que sólo valían el $8 \%$ ), reducía la cantidad de efectivo a sólo $\$ 315.000$. Por otra parte, la aceptación del préstamo por $\$ 600.000$-de los cuáles sólo $\$ 400.000$ ingresaban efectivamente en la Tesorería, pues el resto eran cuentas que Mackintosh tenía contra el gobierno y que de esta forma cobraba fácilmentele evitaban el problema de tener que conseguir los cinco millones de bonos y créditos en el mercado, con el peligro de que éstos pudieran subir de precio, como ocurría algunas veces cuando se trataba de cantidades considerables. Finalmente, con este contrato lograban que el gobierno les reconociera la cantidad de $£ 46.635$ como compensación de un dinero que ellos nunca habían desembolsado, pero que reclamaban como una ganancia que habían dejado de obtener.

Sin embargo, esta última cantidad no les fue reconocida, puesto que ellos faltaron al cumplimiento del contrato al no querer aceptar el pago que el gobierno pretendió hacerles, el $1^{\circ}$ de abril de 1848 , mediante una libranza por $\$ 600.000$ aceptada por Nicanor Béistegui y tampoco accedieron a entregar los créditos, motivo por el cual Luis de la Rosa consideró que el contrato debía ser declarado insubsistente.

Fuente: Rosa (1848: 6-8); Romero (1870: 284 y 285). 


\section{Anexo 4: \\ Resumen de las reclamaciones hechas al gobierno por la casa Manning y Mackintosh}

\begin{tabular}{|c|c|c|c|}
\hline Concepto & Capital & $\begin{array}{l}\text { Réditos al } \\
6 \% \text { anual }{ }^{79}\end{array}$ & Totales \\
\hline $\begin{array}{l}\text { 1. Por no habérseles permitido } \\
\text { exportar, como se convino } \\
\$ 1.825 .000 \text { libres de derechos de } \\
\text { circulación y exportación. }\end{array}$ & $182.500,00$ & $87.600,00$ & $270.100,00$ \\
\hline $\begin{array}{l}\text { 2. Por anticipaciones hechas a } \\
\text { cuenta del préstamo forzoso de } 20 \\
\text { de abril de } 1843 \text {. }\end{array}$ & $70.441,00$ & $54.414,00$ & $124.855,00$ \\
\hline $\begin{array}{l}\text { 3. Por resto del vestuario para la } \\
\text { tropa, entregado en el año de } 1843 \text {. }\end{array}$ & $25.562,34$ & $22.356,54$ & $47.918,88$ \\
\hline $\begin{array}{l}\text { 4. Por resto de las sumas entrega- } \\
\text { das y falta de cumplimiento del go- } \\
\text { bierno a los contratos de } 3 \text { y } 6 \text { de } \\
\text { abril de } 1846 \text {, entre los que se in- } \\
\text { cluyen los gastos de reparación y } \\
\text { anticipo de otros, para la salida al } \\
\text { mar y su venta, de los vapores de } \\
\text { guerra Guadalupe y Moctezuma. }\end{array}$ & $584.000,00$ & $248.026,00$ & $832.026,00$ \\
\hline $\begin{array}{l}\text { 5. Por pérdidas sufridas en la falta } \\
\text { de cumplimiento por parte del go- } \\
\text { bierno, en el arreglo de } 5 \text { de mayo } \\
\text { de } 1846 \text {, para la conversión de la } \\
\text { deuda inglesa. En esta reclamación } \\
\text { no están estimados los réditos al } 6 \\
\text { sino al } 10 \% \text { al año, por ser el pro- } \\
\text { ducto módico que se cree por los } \\
\text { reclamantes, se habría sacado al ca- } \\
\text { pital invertido en la conversión. }\end{array}$ & $1.756 .447,00$ & $2.107 .736,00$ & $3.864 .183,00$ \\
\hline $\begin{array}{l}\text { 6. Por exceso de derecho de con- } \\
\text { sumo pagado en el año de } 1839 \text {. }\end{array}$ & $19.824,00$ & $21.162,00$ & $40.986,00$ \\
\hline $\begin{array}{l}\text { 7. Por derecho de exportación pa- } \\
\text { gado en } 1842 \text {, según determinación } \\
\text { suprema que después se anuló, que- } \\
\text { dando reconocido el exceso pagado. }\end{array}$ & $13.570,00$ & $11.735,00$ & $25.305,00$ \\
\hline
\end{tabular}

79 Los datos de esta columna corresponden a los intereses causados hasta el 31 de marzo de 1858, pero en el informe presentado en marzo de 1871 los encargados de elaborarlo hacen un cálculo de los réditos acumulados en todo el periodo, que da como resultado la cantidad de $14.457 .808,27$ de pesos de réditos. Sin embargo, como también hacen algunas deducciones al total del capital reclamado, la suma de ambos asciende a la cantidad de 28.039.311,75 de pesos. 


\begin{tabular}{|c|c|c|c|}
\hline Concepto & Capital & $\begin{array}{l}\text { Réditos al } \\
6 \% \text { anual }\end{array}$ & Totales \\
\hline $\begin{array}{l}\text { 8. Por falta de cumplimiento por } \\
\text { parte del supremo gobierno, al de- } \\
\text { creto de } 3 \text { de octubre de } 1843 \text {, sobre } \\
\text { cesión de terrenos baldios en el } \\
\text { departamento de Tamaulipas, hecha } \\
\text { en favor del Barón D. Alejandro de } \\
\text { Grox. }\end{array}$ & $7.953 .772,00$ & - & $7.953 .722,00$ \\
\hline $\begin{array}{l}\text { 9. Por suplemento hecho para la } \\
\text { conversión de la deuda inglesa en } \\
1846 \text {. }\end{array}$ & $248.918,19$ & $144.746,81$ & $393.665,00$ \\
\hline $\begin{array}{l}\text { 10. Por suplementos hechos al su- } \\
\text { premo gobierno por el convento del } \\
\text { Carmen de México. }\end{array}$ & $216.338,99$ & $248.029,01$ & $464.368,00$ \\
\hline $\begin{array}{l}\text { 11. Por daños y perjuicios sufridos } \\
\text { en la anulación del privilegio con- } \\
\text { cedido a D. José Garay, para la co- } \\
\text { municación de los dos mares por el } \\
\text { Istmo de Tehuantepec. }\end{array}$ & $500.000,00$ & - & $500.000,00$ \\
\hline $\begin{array}{l}\text { 12. Por daños y perjuicios causados } \\
\text { en la denegación de justicia por } \\
\text { parte de los tribunales mexicanos en } \\
\text { el pleito de la Mina de La Luz. }\end{array}$ & $2.000 .000,00$ & - & $2.000 .000,00$ \\
\hline $\begin{array}{l}\text { 13. Por sueldos suplidos al C. Joa- } \\
\text { quín de Castillo y Lanzas, como mi- } \\
\text { nistro plenipotenciario en Londres. }\end{array}$ & $10.179,96$ & $5.077,76$ & $15.257,72$ \\
\hline Total & $13.581 .503,48$ & $2.950 .883,12$ & $16.532 .386,00$ \\
\hline
\end{tabular}

Fuente: Romero (1870: 928, 929). 



\author{
Carlos Riojas*
}

\title{
Consideraciones metodológicas para el estudio del proceso de industrialización en el occidente de México durante el siglo XIX
}

\section{Introducción}

Diversos son los enfoques para abordar el estudio de los espacios que viven o intentan un proceso de industrialización, sin embargo, dos elementos en común los identifican: una creciente rigurosidad científica y un aumento en los factores explicativos. De las opciones metodológicas que más éxito han tenido en los últimos veinte años destacamos la propuesta protoindustrial. El presente ensayo tiene básicamente dos objetivos. El primero de ellos radica en presentar el modelo protoindustrial: sus orígenes, sus elementos, sus refinamientos y su consolidación a nivel internacional; para tal efecto, hago una presentación de sus componentes esenciales, asimismo doy cuenta de su aceptación en México y otros países. Finalmente señalo sus ventajas y límites. A pesar de la difusión del paradigma, en ocasiones el concepto se usa indiscriminadamente, sobre todo en México. Presento mi opinión al respecto y ejemplifico con el caso de Jalisco durante el siglo XIX.

El segundo objetivo consiste en intentar responder a las siguientes preguntas: ¿Realmente la propuesta protoindustrial nos ayuda a explicar coherentemente la formación de una sociedad semiindustrializada como la de Jalisco? ¿Acaso la investigación histórica sobre el proceso de industrialización en Jalisco se encuentra lo suficientemente avanzada para utilizar un modelo como el protoindustrial? ¿Existe alguna correspondencia con otras interpretaciones que analizan a través del tiempo los problemas económicos de países subdesarrollados? Tomo el caso de Jalisco porque es el que conozco mejor. Tengo la esperanza de que este ensayo despierte la curiosidad entre mis colegas para ana-

* Agradezco al Consejo Nacional de Ciencia y Tecnología de México el apoyo para la elaboración de esta investigación, la cual forma parte de un proyecto más amplio (Ref. 40016H). 
lizar distintos proceso de industrialización, así como los desafíos que ello implica, para los llamados países subdesarrollados.

\section{Los antecedentes de la protoindustrialización}

El fenómeno de la revolución industrial se considera el punto de partida que da como resultado la consolidación de sociedades industrializadas; el primer país modelo en este tipo de estudios es Inglaterra. ${ }^{1}$ Algunos autores definen el fenómeno como "un trasfondo complejo de cambios técnicos en los medios y modo de producción" (Landes 1961: 6), pero las causas originarias del proceso se estudian en una perspectiva más amplia. Trabajos clásicos insisten en las irreversibles transformaciones sociales, políticas y, por supuesto, económicas, ${ }^{2}$ la escuela histórica alemana enfatiza la industrialización doméstica; también hay quien analiza el desarrollo general del sistema capitalista, con sus diferentes ritmos y épocas. ${ }^{3}$

La revolución industrial es la última etapa de transición entre dos modos de producción distintos: el feudalismo y el capitalismo, época en la que persisten elementos característicos de ambos sistemas. ${ }^{4}$ En un principio, se detectan algunos factores de cambio: la búsqueda del excedente en la producción impulsa la transformación de una economía tradicionalmente ligada a la posesión de la tierra, el crecimiento de la productividad agrícola desencadena el aumento poblacional y la aparición progresiva de grupos de trabajadores-propietarios crea un contingente de mano de obra, situaciones que favorecen la expansión de distintos mercados. Lo anterior repercute en la producción de manufacturas.

Sin embargo, la influencia de la revolución industrial no se limita a los países donde se producen los cambios; si algunas regiones del mundo viven un proceso de crecimiento y desarrollo económicos, otras sufren un proceso de subdesarrollo; la necesidad de encontrar materias primas para continuar con la producción, pero sobre todo los compradores de manufacturas provocan la creación de un mercado

1 Hobsbawm (1977: 16, 18-19, 32); O'Brien (1986: 293).

2 Marx (1993); Mantoux (1905); Ashton (1983); Landes (1975); Rostow (1962); Hobsbawm (1971).

3 Kriedte et al. (1986); Braudel (1979); Dobb (1988).

4 Sweezy et al. (1964); Dobb (1988: 21, 25, 31). 
mundial. Paralelamente, se ven afectados otros procesos de industrialización que gradualmente se desarrollan, no sin problemas y limitaciones internas. ${ }^{5}$ Para América Latina, algunos autores ven el atraso económico como una parte del proceso histórico global de desarrollo capitalista ${ }^{6}$ situación que origina la formación de sociedades semiindustrializadas, bien definidas desde la primera mitad del siglo XX.

A pesar del reconocimiento de algunos elementos que desencadenan la revolución industrial el debate continúa. Uno de los paradigmas que responde mejor al torrente de cuestiones es la propuesta de Franklin Mendels (1972: 241-261) basada en una investigación histórica sobre Flandes: la protoindustrialización como la primera fase de la industrialización; las sugerencias de Mendels son retomadas y ampliadas por otros investigadores. Si para los estudios de la revolución industrial Inglaterra es el modelo, el paradigma válido para la protoindustrialización es Flandes. En una obra monumental Peter Kriedte, Hans Medick y Jürgen Schlumbohm la definen como "la industrialización antes de la industrialización" (1986); es decir, el crecimiento económico de regiones rurales, donde la población vive fundamentalmente de la producción masiva de manufacturas, que se distribuyen en los mercados regionales e internacionales. Por su parte, Wolfgang Mager señala que dicha proposición es una extensión de la Escuela Histórica Alemana y que se confunde protoindustria con protoindustrialización, lo que implica pasar por alto la dinámica del proceso (Mager 1993: 185-186).

El excedente agrícola permite el crecimiento constante de la población y la producción manufacturera en zonas rurales, así como el progreso del comercio impulsa el desarrollo urbano. Este incipiente proceso global de industrialización ayuda al crecimiento económico en general a través del tiempo y del espacio, además representa, según el modelo, los elementos suficientes para lograr la industrialización. ${ }^{7}$ La argumentación innovadora de la protoindustrialización radica en considerar la extensión de la industria doméstica como una etapa preliminar a la revolución industrial, mientras que antes ésta era vista como la última secuela de un sistema feudal en vías de extinción (De-

5 Bairoch (1990); Hobsbawm (1977: 33, 49, 77, 173, 269).

6 Sunkel (1971: 6); Furtado (1979: 30).

7 Cailly (1993: 19-20); Desama (1981: 147-148); Kriedte et al. (1986: 18, 27, 40). 
yon 1979: 9). Cabe aclarar que no en todos los contextos estudiados prevalecen las mismas características; tampoco la protoindustrialización es la antítesis de la gran industria concentrada, pero puede ayudar a comprender las vinculaciones establecidas entre las economías agrarias y el advenimiento del capitalismo industrial. Para Pierre Jeannin (1980: 52) la propuesta es ambiciosa, y abre la puerta a investigaciones metódicas en un terreno generalmente confuso para la historia económica. ${ }^{8}$

\section{La consolidación del modelo}

Según el modelo, durante la fase protoindustrial se observa un excedente de mano de obra debido al crecimiento demográfico; una parte de la fuerza de trabajo comienza a realizar tareas manufactureras en el campo, al punto de especializarse en ellas y así complementa su ingreso familiar. Este fenómeno representa una hipótesis fundamental para la protoindustrialización; es decir, el empleo temporal en procesos manufactureros engendra un movimiento de proletarización de campesinos, los cuales deben adaptarse a nuevos ritmos de trabajo, una parte de la producción manufacturera es controlada por un fabricantemercader (Verleger), la cual está destinada al mercado. En el esquema la complementariedad entre regiones especializadas es indispensable para el crecimiento económico en general; incluso esta relación puede presentarse entre espacios urbanos y rurales de una misma región, aun cuando Mendels no lo prevé en un principio.?

La consolidación del modelo protoindustrial se da gracias a que su estructura permite hacer un análisis multivariable, en periodos de transición donde se traslapan las etapas de desarrollo del sistema capitalista. Si bien es cierto que los estudios de caso muestran las limitaciones del enfoque, no menos cierto es que contribuyen con nuevos elementos que al final de cuentas lo refuerzan; ${ }^{10}$ entonces, ¿acaso el modelo

8 Belfanti (1993: 254-255); Hohenberg (1996: 11); Leboutte (1996a: 272); Lewis (1994: 161); Sabel/Zeitlin (1985: 133-134, 136).

9 Deyon/Mendels (1981: 11); Deyon (1984: 868); Ho (1984: 894); Chao (1984: 958); Mendels (1972: 254; 1984: 945; 1986: 264); Ogilvie (1993: 159-179); Mager (1993: 182); Ciriacono (1996: 317, 304); Van der Wee/D'Haeseleer (1996: 259-58); Gutmann (1996: 154, 156); Hohenberg (1996: 9).

10 Kriedte et al. (1996: 36); Leboutte (1996b: 7); Berg (1996: 213); Belfanti (1993: 253); Sabel/Zeitlin (1985: 139, 141). 
protoindustrial conserva su mismo poder explicativo para regiones que ven frustrado parcialmente su proceso de industrialización, como sucede en el occidente de México, en particular Jalisco? A continuación comento el papel de los elementos que intervienen en la protoindustrialización, y después responderé a la pregunta.

\subsection{Los factores demográficos}

La baja en el índice de mortalidad, el aumento en el número de matrimonios y el índice de fecundidad son elementos que influyen sobre el crecimiento demográfico de espacios protoindustriales. El incremento constante de la población es un prerrequisito para implementar la división del trabajo en la agricultura, fenómeno que se acompaña con el alza regular de la productividad. Por su parte, las actividades manufactureras se multiplican gracias a la ocupación de nuevos espacios y a la centralización comercial en las ciudades y sus alrededores. ${ }^{11}$ La estructura familiar deviene una variable crítica del modelo protoindustrial al explicar un comportamiento demográfico específico, además permite relacionar los análisis micro y macroeconómico; donde el matrimonio y la familia son indispensables para producir de forma independiente. ${ }^{12}$ Para la familia de espacios protoindustriales es ventajoso casarse joven y tener hijos inmediatamente, entre más grande es ésta, el potencial productivo crece; asimismo, existe la posibilidad de que en el hogar vivan otros miembros que no pertenecen a la familia nuclear, lo que hace más complejas las relaciones establecidas en el sistema protoindustrial. Adelantar la edad para casarse no es un fenómeno que responde a circunstancias estrictamente económicas, también intervienen los contextos social, cultural e institucional. Por lo tanto, no en todas las regiones protoindustriales se modifica la edad de los matrimonios, incluso en algunas de ellas no hay cambios significativos. También, destacan los constantes movimientos migratorios, donde se incluye la movilidad de zonas de agricultura comercial hacia áreas donde predomina la industria doméstica rural o el incipiente sistema fabril, lo que desemboca en la expansión geográfica de espacios protoindustriales como una vía complementaria al crecimiento demo-

11 Mendels (1972: 250); Kriedte et al. (1986: 19).

12 Pfister (1996: 79); Kriedte et al. (1993: 219, 225); Cerman (1993: 292). 
gráfico. ${ }^{13}$ Otro elemento que repercute sobre la estructura familiar es la división de las tareas productivas en el hogar. En un principio, la mujer y el hombre consagran el mayor tiempo posible de sus vidas al trabajo, a tal grado que se alcanza una situación de "autoexplotación", después todos los miembros de la familia participan. ${ }^{14}$ La redistribución de los papeles, desde la perspectiva de género y edades entre los miembros de la familia, impacta decisivamente la protoindustrialización; también vale la pena destacar que no necesariamente existe una continuidad entre la familia de espacios protoindustriales y la proletaria, entre ambos tipos pueden existir rupturas históricas. ${ }^{15}$

El crecimiento demográfico impulsa la expansión del sistema protoindustrial y un avance económico sin precedentes, el que de continuar con ese mismo ritmo, amenazaría con convertirse en factor de crisis, por tanto, no puede perpetuarse sin mecanismos de regulación. Uno de estos mecanismos se encuentra en la tasa de mortalidad infantil; el sistema demoeconómico de regiones protoindustriales incrementa la presión demográfica, lo que se refleja en cambios socioeconómi$\cos ^{16}$

La conservación de la misma superficie cultivable y el aumento del número de los miembros de la familia reducen el ingreso real, lo que conduce a éstos últimos a buscar nuevas fuentes de empleo. El factor de producción tierra es escaso con relación a otros factores, lo que en el largo plazo determina la distribución del ingreso, el nivel de vida y los derechos de propiedad; la contraparte al aumento en la oferta de trabajo es el incremento en la demanda interna, que en ocasiones se cubre gracias a la especialización y comercialización regional o internacional. ${ }^{17}$

Otra característica de los espacios protoindustriales es la reducción de efectivos que laboran en la agricultura; si la fuerza de trabajo es un factor relativamente abundante, los pagos a la misma tienden a disminuir, lo que induce a los miembros de la familia a trabajar en activida-

13 Kriedte et al. (1996: 33, 40, 41); Levine (1996: 96, 94, 104); Leboutte (1996a: 287); Ogilvie (1993: 175); Hudson/King (1996: 189, 194); Pfister (1996: 78).

14 Deyon (1984: 874); Leboutte (1996a: 268).

15 Vandenbroeke (1996: 242); Levine (1996: 94); Saito (1996: 130, 132, 134, 136, 144, 149); Ciriacono (1996: 311); Cerman (1993: 306).

16 Kriedte et al. (1996: 30); Cerman (1993: 292, 303, 306).

17 Hohenberg (1996: 12); Kriedte et al. (1996: 49); Leboutte (1996b: 7); Chaudhuri (1996: 123). 
des manufactureras por una remuneración baja; lo anterior se debe a que estas personas ven en las manufacturas un complemento para el ingreso familiar. ${ }^{18}$ Asimismo, el excedente de fuerza de trabajo repercute en el ritmo de innovación técnica e invención tecnológica; algunos autores han visto la protoindustrialización como estrategia para economizar capital y utilizar más intensivamente la mano de obra en espacios donde predomina un subempleo estructural, asimismo presenta un bajo costo de oportunidad al abandonar las tareas agrícolas, lo que impacta la organización social y económica. ${ }^{19}$ Por lo que concierne a los propietarios de grandes extensiones de tierra, es más ventajoso rentar una parte que invertir en ellas; una proporción de su capital sirve para financiar otras actividades, donde destaca la industria doméstica, que se encuentra en estrecha relación con la explotación cada vez más intensiva de los terrenos dedicados a la agricultura. ${ }^{20}$

\subsection{Los factores agrícolas}

Una diferencia fundamental entre las áreas preindustriales y protoindustriales se encuentra en la organización del espacio rural y en el aumento constante de la productividad agrícola a través del tiempo (Bairoch 1983: 496), la modernización de la agricultura comercial contribuye a la expansión de mercados internos y externos.

Los campesinos dedican cada vez más tiempo a tareas no agrícolas para completar su ingreso y mantener su nivel de vida; el contexto agrícola es clave para impulsar la protoindustrialización. En un principio se piensa que dicho fenómeno proliferaba en áreas con limitaciones en el desarrollo agrícola, pero se constata que también surge en lugares de alta productividad donde los recursos no utilizados se dirigen hacia otras labores productivas, la retroalimentación entre la agricultura y esta incipiente industria se favorece con la aparición de pequeños propietarios, que canalizan independientemente los recursos productivos del medio rural e impactan los hogares protoindustriales. ${ }^{21}$

18 Hendrickx (1993: 323, 326); Levine (1996: 102).

19 Chaudhuri (1996: 123); Hohenberg (1996: 21); Ogilvie (1993: 165); Pfister (1996: $79,80)$.

20 Cailly (1993: 24); Kriedte et al. (1986: 91, 96, 114, 121, 128, 129); Ho (1984: 884-885); Jeannin (1980: 57); Chao (1984: 959-960); Vandenbroeke (1996: 238).

21 Belfanti (1993: 271-272); Hendrickx (1993: 332); Kriedte et al. (1993: 228, 224, 231; 1996: 53, 56); Mager (1993: 192). 
Durante la temporada muerta, como ocupación alternativa, los campesinos elaboran de forma descentralizada algunos bienes manufacturados para su propio consumo, si a ello agregamos los bajos costos del capital fijo y circulante, estas actividades son aún más atractivas. Sin embargo, los productos agrícolas son todavía la base de su subsistencia, además marcan los ritmos y tiempos de la producción. ${ }^{22}$

La intensificación del crecimiento demográfico conduce a los campesinos a especializarse en la producción manufacturera dirigida al mercado, aun si la ganancia es mínima, ésta le permite completar su ingreso familiar y realizar más regularmente este tipo de trabajo durante el año; la familia en este contexto agrícola deviene una institución crucial. La combinación de los distintos tipos de trabajos transforma la vida de los miembros de la familia campesina, que se convierten en campesinos-artesanos, como parte de un proceso de proletarización; a pesar de que muchos de ellos mantienen pequeñas propiedades en su poder, la tendencia es la pérdida de éstas, para depender más del pago recibido por sus tareas manufactureras. ${ }^{23}$ Posteriormente, los campesinos-artesanos son financiados por un Verleger, quien suministra materias primas y algunos medios de producción a fin de facilitarles las labores productivas, tendientes a la producción en masa (Hendrickx 1993: 332). Estas transformaciones se encuentran ligadas al ciclo agrícola; sin embargo, paulatinamente se alejan para tomar una trayectoria independiente e inscribirse en el universo protoindustrial.

\section{$3.3 \mathrm{El}$ Verlagssystem}

La relación establecida entre los campesinos-artesanos y el Verleger es clave en el esquema protoindustrial, basándose en ella se propaga la producción doméstica de manufacturas masivamente; lo anterior toma mayor dinamismo cuando las mercancías se dirigen a mercados supraregionales. El Verleger o los personajes similares son esenciales, por lo tanto, surge la necesidad de ampliar los conocimientos sobre éstos y

22 Dewerpe (1984: 900); Belfanti (1993: 258-267); Mager (1993: 191); Ogilvie (1993: 163).

23 Desama (1981: 152); Kriedte et al. (1993: 229, 231; 1996: 32, 51); Hohenberg (1996: 14); Levine (1996: 100); Leboutte (1996a: 290); Ogilvie (1993: 166, 169). 
sus relaciones establecidas con el sistema económico y social, ${ }^{24}$ el contexto es determinante para la consolidación de esta relación, se destacan regiones donde una parte de la fuerza de trabajo se encuentra sobreempleada o subempleada en función del ciclo agrícola, situación que influye en el nivel de subsistencia.

La regulación de corporaciones artesanales en la ciudad limita la acción de artesanos nuevos o independientes, así como las tareas de los comerciantes. Generalmente, estos últimos por medio de sus actividades vinculan distintas plazas comerciales, la ciudad y el campo; si por un lado, las corporaciones artesanales restringen la producción manufacturera, por el otro, la ciudad representa un espacio favorable para el progreso del esquema protoindustrial al destacarse como lugar de intercambio por excelencia; incluso se argumenta que las relaciones entre ciudad y campo se fortalecen, gracias al contacto entre el Verleger y los campesinos-artesanos. ${ }^{25}$

El fabricante-mercader adelanta dinero para la compra de materias primas, medios de producción y pagos al trabajo realizado por los miembros de la industria doméstica, además, ofrece una estabilidad laboral tendiente a incrementar la posibilidad de dar trabajo a más personas. Este tipo de organización productiva origina beneficios para el Verleger, pero la expansión de la industria doméstica en el campo tiene sus límites al incrementar los costos de transacción, ${ }^{26}$ asimismo, los antiguos artesanos rurales aceptan las nuevas modalidades de organización laboral. Sin embargo, la falta de capital es un problema que aqueja constantemente a la industria doméstica, la intervención del Verleger ayuda a resolver la dificultad, no obstante, estos pequeños fabricantes devienen más dependientes del capital adelantado, relación que sirve como la fuerza motriz del sistema. Regularmente, el comerciante invierte sólo el capital indispensable, mientras que el Verleger necesita un capital extra; es decir, la tasa de beneficio para

24 Mager (1993: 186); Lewis (1994: 154); Van der Wee/D'Haeseleer (1996: 252); Pfister (1996: 83).

25 Chaudhuri (1996: 115); Ogilvie (1993: 169); Lewis (1994: 154); Pfister (1996: 81).

26 Mager (1993: 193, 200); Belfanti (1993: 268); Gutmann (1996: 173, 175); Kriedte et al. (1996: 59). 
éste debe ser atractiva a fin de que se sienta motivado para financiar a los campesinos-artesanos. ${ }^{27}$

Existen dos formas básicas de transición hacia el modo de producción capitalista: la expansión del capital comercial sobre las bases precapitalistas y la formación de capital en la esfera de la producción; el sistema protoindustrial se caracteriza por la presencia de ambas. La tendencia en el Verlagssystem reside en que los pequeños productores trabajan por encargo y pierden mucha de su independencia mantenida en el Kaufsystem, donde los artesanos utilizan su propia fuerza de trabajo y medios de producción, sus productos son vendidos por ellos en el mercado. Al evolucionar este sistema se dirige hacia el Verlagssystem, lo que implica aumentar el capital fijo para fortalecerlo; en un Verlagssystem avanzado existe una división entre la fuerza de trabajo y los medios de producción, poco a poco los trabajadores se inician en la disciplina que exige la industria, el Verleger impone normas de producción cuantitativas y cualitativas, detrás de las cuales se perfila toda una racionalización en el mundo productivo. ${ }^{28}$

\subsection{El mercado}

El principal factor que contribuye a la consolidación definitiva del sistema protoindustrial es la creciente demanda de los mercados; en algunas regiones existe una especialización flexible en función del tipo de bien y del mercado de destino. Tradicionalmente, la demanda local es relativamente débil y está sujeta en gran parte al ciclo agrícola, así el comercio a larga distancia está en función de la acumulación de capital, precios relativos de la competencia, calidad e información de productos, regularidad cuantitativa tanto de la oferta como de la demanda y desempeño de los transportes. El empresario responsable de la distribución es precisamente el Verleger, al mismo tiempo sus empresas están obligadas a funcionar con una racionalización progre-

27 Braudel (1979, II: 371, 372); Mendels (1972: 242, 246; 1981: 256); Kriedte et al. (1986: 20, 80); Desama (1981: 150).

28 Weber (1991: 176, 184, 372); Kriedte et al. (1986: 23, 161, 164); Mendels (1981: 256); Cailly (1993: 32); Deyon (1979: 240); Deyon/Mendels (1981: 12); Pfister (1996: 88); Van der Wee/D'Haeseleer (1996: 253). 
siva que dicta sus reglas, situación que genera una economía de mercado. $^{29}$

Cuando una región se define como protoindustrial se impulsa la división del trabajo, sin embargo, la piedra angular es la formación de los mercados mundiales, que favorecen el nacimiento de las metrópolis, las cuales controlan los espacios coloniales o de ultramar, cuyos mercados están sujetos a la producción de regiones protoindustriales. En algunas áreas hay mayor resistencia a los impactos económicos que ello implica, donde la vida cultural juega un papel importante, tales fueron los casos de la India y China; en América Latina el panorama es distinto, la producción de regiones protoindustriales penetra temprana y prácticamente sin resistencia alguna de los mercados. ${ }^{30}$

El impacto de este fenómeno supera la escala local o regional, además define irreversiblemente una nueva organización en las relaciones sociales y económicas internacionales; el crecimiento económico de regiones protoindustriales es el origen de la formación de las concentraciones industriales especializadas en la producción masiva. Este entramado económico provoca una complejidad creciente en las relaciones monetarias y en las de mercado, a tal punto que resultan indispensables para la protoindustrialización. ${ }^{31}$ Cuando la demanda de un bien manufacturado es relativamente grande, la tarea se reparte entre distintas unidades de producción; los problemas de insuficiencia productiva son resueltos por la introducción de nuevas técnicas o tecnologías, esta demanda creciente genera efectos multiplicadores en algunos sectores económicos, intensificación de los intercambios locales y aceleración del proceso de urbanización; en los mercados urbanos es donde se incuba el dinamismo característico de la protoindustrialización, pese a los obstáculos institucionales. ${ }^{32}$

29 Kisch (1986: 297); Belfanti (1993: 270 y 272); Leboutte (1996a: 263, 279; 1996b: 6); Chaudhuri (1996: 113, 116, 120, 121); Lewis (1994: 157); Mager (1993: 194); Pfister (1996: 83, 87); Braudel (1979, I: 8).

30 Miño (1993: 12); Thomson (1991: 243); Jeannin (1980: 54); Chaudhuri (1996: 109, 114, 115, 121); Van der Wee/D'Haeseleer (1996: 224).

31 Sunkel (1971: 46); Mendels (1972: 248; 1981: 256); Kriedte et al. (1986: 13, 21).

32 Deyon (1979: 243); Deyon/Mendels (1981: 11); Cerman (1993: 285); Mager (1993: 189); Ogilvie (1993: 171). 


\section{Limites y críticas del modelo}

Expuse uno de los modelos teórico-metodológicos más completos y controvertidos. Pero, ¿acaso encontramos límites o críticas a esta seductora perspectiva?, ¿cuál es su impacto entre las múltiples interpretaciones del proceso general de industrialización?, ¿cuáles son las fuentes de su éxito como modelo explicativo?

Una de las limitaciones primordiales de la teoría protoindustrial es la importancia excepcional que otorga al contexto agrícola, donde las actividades urbanas pasan a un segundo plano. En otros trabajos Mendels reconoce esta limitación e intenta subsanar la omisión de la ciudad al proponer una nueva interpretación, ante la crítica virulenta de especialistas (Mendels 1981: 11). Queda de manifiesto que el medio rural no representa obligatoria y universalmente el lugar idóneo para la proliferación de dichas actividades. El hecho de que algunas ramas manufactureras se desarrollen esencialmente con mano de obra rural, no es un criterio suficiente para minimizar otros casos donde la ciudad ofrece las condiciones propicias para la multiplicación de pequeñas unidades productivas de carácter familiar; por lo tanto, la separación urbano-rural no es universalmente pertinente en el análisis del proceso de industrialización. Al fin de cuentas, para Maxine Berg es una falsa dicotomía (1996: 214), donde influyen la interpenetración de variables dinámicas y estáticas. ${ }^{33}$

Este mismo paradigma enfrenta el problema de la delimitación entre los conceptos preindustrial y protoindustrial, lo que implica tiempos, lógicas y contextos institucionales distintos. ${ }^{34} \mathrm{~A}$ pesar de que Mendels pretende dejar claro lo que él entiende por protoindustrial, la incertidumbre persiste; el debate gira de nuevo hacia la articulación entre las actividades urbano-rurales, pero lo más significativo son los tipos de mercados a los que se tienen acceso y no el antagonismo por definición entre sus actores, como la oposición entre los intereses de las corporaciones artesanales y del Verleger. Basándose en estos personajes se configura una visión simplista o exagerada, pero la realidad se presenta más compleja en un contexto cambiante, asimismo, se

33 Maitte (1997: 1284); Mager (1993: 181, 201).

34 Braudel (1979, II: 356; III: 475); Belfanti (1993: 264, 265, 267); Cerman (1993:

283); Ciriacono (1996: 294). 
llega a hablar de una protoindustria urbana, lo que en la década de los setenta era una incongruencia en el debate. ${ }^{35}$

En el marco de la investigación histórica es difícil determinar con precisión el tipo de articulación manifestada entre los actores con los criterios estrictos del modelo. Por lo general, los vínculos establecidos se mezclan con otras formas y características; solamente una investigación constante y de largo plazo permitiría realizar dichas abstracciones, las actividades de los campesinos-artesanos no se reducen a los trabajos en el campo o en las manufacturas, es factible que se transformen en agentes comercializadores, lo que apoya la hipótesis sobre la pluriactividad en las zonas rurales más que la protoindustrialización y daría como resultado una perspectiva aún más compleja. ${ }^{36}$

En Prato, Italia, la estructura y organización social fragmentada dan como resultado la conformación de territorios manufactureros durante el siglo XIX, que no cumplen con los criterios del Verlagssystem. Apegarse estrictamente al modelo impide apreciar totalmente las evidencias empíricas, incluso las vías que toman los procesos de desarrollo local divergentes. Ejemplo de ello es la transformación de áreas protoindustriales en distritos industriales como una especificidad regional o el tipo de inserción en el comercio mundial desde épocas remotas o tardías; la coexistencia entre diferentes unidades productivas es factible en el proceso general de industrialización. ${ }^{37}$

Independientemente de las divergencias regionales, tres resultados son claros: en primer lugar, la visión protoindustrial deriva en una cantidad de estudios regionales en diferentes periodos históricos que redefinen la discusión y nos advierten sobre la complejidad del fenómeno; en segundo lugar, se consagra como un modelo "demoeconómico" al identificar variables clave, cuyo antecedente está en la demografía histórica con ciertas evidencias que lo apoyan; por último, una vez constatada la generalización de la propuesta, el desafío consiste en

35 Cailly (1993: 24); Maitte (1997: 1287); Cerman (1993: 281, 282, 285); Berg (1996: 216, 217, 235); Leboutte (1996b: 4); Lewis (1994: 152-153).

36 Carneiro (1996: 9); Hubscher (1996: 1-24); Cailly (1993: 31, 34, 36).

37 Berg (1996: 220-221); Cerman (1993: 281, 283, 286); Hendrickx (1993: 328); Chaudhuri (1996: 107); Maitte (1997: 1286, 1288); Belfanti (1993: 255, 273); Ciriacono (1996: 291, 294); Ogilvie (1993: 161). 
incorporar en una estructura lógica las evidencias y críticas al modelo en busca de una interpretación más completa. ${ }^{38}$

Por otra parte, se argumenta que la industria doméstica no es precisamente un factor de progreso económico; es necesario tomar en cuenta las condiciones donde se presenta la innovación técnica, la flexibilidad de las unidades productivas, la propiedad o tipos de herramientas y maquinarias empleadas, el acceso a las fuentes de financiamiento, la capacidad empresarial para insertarse en redes productivas formales o informales, así como las políticas de organizaciones que influyen en la vida pública, ${ }^{39}$ por lo tanto, el medio institucional influye de forma determinante. Cabe aclarar que en la protoindustrialización la industria doméstica es un elemento clave, pero ésta última es independiente y presenta a través de la historia diferentes edades. ${ }^{40}$

Si tomamos en cuenta que el modelo protoindustrial sirve de base en los periodos de transición, no se pueden definir las regiones como tales hasta que una gran parte de las transformaciones señaladas se encuentran en un estadio bastante avanzado. La crítica gira en torno a crear una tipología más apropiada debido a que no todos los fenómenos pueden ser denominados simple y llanamente protoindustriales; la tarea deviene aun más compleja ya que la protoindustrialización se ubica precisamente en la transición de los modos de producción, la cual no se gesta de forma lineal ni continua, tampoco se divide en dos bloques antagónicos, además, se tiene previsto el fenómeno de desindustrialización que es igualmente difícil de medir con precisión dado su carácter intermitente. ${ }^{41}$

Asimismo, es importante subrayar que el modelo no hace un análisis exhaustivo de los factores que regulan el crecimiento demográfico a través del tiempo en las regiones susceptibles de industrializarse completamente, lo anterior es crucial; algunas evidencias empíricas en Europa, una vez más, juegan en contra de las predicciones de la teoría. Ante diferentes patrones de conducta demográfica, la estructura económica no siempre influye igual sobre los habitantes, es necesario

38 Hohenberg (1996: 26-27); Kriedte et al. (1993: 222; 1996: 31); Leboutte (1996b: 2); Pfister (1996: 91).

39 Berg (1996: 232); Hendrickx (1993: 335); Hudson/King (1996: 205-206).

40 Kriedte et al. (1993: 218; 1996: 58, 64); Lewis (1993: 156).

41 Maitte (1997: 1282); Mager (1993: 183-187); Belfanti (1993: 264); Kriedte et al. (1993: 218); Ogilvie (1993: 167, 171, 173); Sabel/Zeitlin (1985: 144). 
distinguir contextos agrarios específicos, fluctuaciones y peculiaridades de las ramas productivas en la región. ${ }^{42}$

Otro punto débil del modelo es la atención sesgada que reciben las actividades textiles, al descuidarse los vínculos socioeconómicos existentes en otras tareas manufactureras. Tradicionalmente el panorama protoindustrial está dominado por la existencia de talleres del ramo textil, en menor medida aparecen pequeñas fundiciones, la fabricación de porcelana o dulces, por ejemplo; estos últimos ramos son importantes en el proceso de industrialización, que depende más de la disponibilidad de capitales, de fuentes de energía y de la mano de obra rural, y no de un solo sector. ${ }^{43}$ Por lo que concierne a la obra de Kriedte et al. (1986), algunos autores recomiendan prudencia en la utilización del concepto al juzgarlo too much o un peu gonflé ${ }^{44}$ Dentro de la discusión de la revolución industrial, una parte del debate plantea reconsiderar el papel que juegan las transformaciones sufridas en los hogares durante el proceso; asimismo, cada vez se hace más énfasis en la matriz institucional, ${ }^{45}$ enfoques que proponen mayor flexibilidad, lo que escapa a los objetivos del presente trabajo.

\section{La aceptación del modelo}

Si partimos del proceso de industrialización en general, es difícil negar la aceptación del modelo protoindustrial al hablar de la formación de sociedades industrializadas, especialmente si se toma en cuenta que establece nuevos vínculos con interpretaciones tradicionales (Maitte 1997: 1277). Después de la propuesta de Mendels lanzada en 1972, surge un periodo de refinamiento y discusión sobre cada uno de los elementos constitutivos del paradigma, pero su valor holístico es poco atacado. ${ }^{46}$ Posteriormente, como una herencia importante, se levanta una ola de trabajos a nivel mundial consagrados a casos precisos en contextos socioeconómicos diferentes, tanto en el interior como en el

42 Hendrickx (1993: 328, 338, 340, 348, 350); Kriedte et al. (1993: 219; 1996: 42); Mager (1993: 181); Ogilvie (1993: 175).

43 Berg (1996: 212); Leboutte (1996a: 270); Mager (1993: 199); Jeannin (1980: 53, 63); O'Brien (1986: 302).

44 Coleman (1983: 435-448); Jeannin (1980: 64).

45 Vries (1994: 249); Berg (1996: 215); Hohenberg (1996: 15); Lewis (1994: 160); Pfister (1996: 74).

46 Vandenbroeke (1984: 915-938); Kriedte et al. (1993: 223). 
exterior de Europa, que gracias a sus perspectivas espaciales permiten una distinción interregional e intrarregional del fenómeno y establecen las conexiones económicas e institucionales en el proceso de industrialización. ${ }^{47}$

Resulta complicado hacer un balance completo sobre el impacto de este modelo, sobre todo si se toman en cuenta las últimas etapas. Aquí me limito a mencionar algunos trabajos que considero importantes desde esta perspectiva sin pretender hacer un balance general. Cabe aclarar que cito pocos trabajos de casos alemanes, debido a mis limitaciones lingüísticas, pero de ninguna forma le resto importancia a las aportaciones de esta escuela, protagonista fundamental en la discusión.

Existen trabajos que, con base en un análisis económico, intentan formalizar algunas relaciones que se presentan en las sociedades protoindustriales. ${ }^{48}$ Para el caso italiano, además de los trabajos citados, está el estudio de Alain Dewerpe en el que señala la presencia de un sistema de explotación a gran escala en la industria doméstica, mientras que los hombres van al campo las mujeres a las fábricas, sugiere este autor. ${ }^{49}$ Por lo que concierne a Francia, cuya tradición en la investigación histórica aporta bastantes elementos a la discusión, tengo en mente el trabajo de Serge Chassagne (1991) y otros más. ${ }^{50}$ El número uno de la Scandinavian Economic History Review en 1982 se dedica a discutir la protoindustrialización en los países escandinavos. ${ }^{51}$ Evidentemente sobre Inglaterra existe una bibliografía importante. ${ }^{52}$ El caso de Rusia es interesante desde el ángulo protoindustrial. ${ }^{53}$ El nacimiento de la industria en España se estudia según esta misma perspectiva

47 Cerman (1993: 288-289); Ciriacono (1996: 293); Kriedte et al. (1996: 29); Leboutte (1996b: 1, 4); Lewis (1994: 161); Hudson/King (1996: 197); Hendrickx (1993: 325, 324).

48 Ho (1984: 882); Pfister (1996: 74, 90).

49 Dewerpe (1984; 1985); Poni (1982).

50 Cayez (1981); Gullickson (1982); Locke (1981); Goujon (1984); Bergeron (1984); Zeitlin (1985); Lewis (1994).

51 Hornby/Oxenbøll (1982); Hoffman (1982); Hovland/Nordvik/Tveite (1982); Schön (1982); Magnusson/Isacson (1982).

52 Hudson (1981); Kriedte (1983); Husbands (1987); Sabel/Zeitlin (1985: 133-176); Hudson/King (1996); Laslett (1969).

53 Rudolph (1985); Melton (1987). 
en las diversas regiones que la componen, ${ }^{54}$ asimismo, Portugal no escapa del enfoque protoindustrial (Pedreira 1990).

Fuera del contexto europeo existen algunas investigaciones sugestivas, pero es incomparable con la cantidad de trabajos que conciernen a Europa. Además, fuera de este espacio la discusión no siempre alcanza el mismo rigor conceptual, especialmente en México, donde se utiliza el concepto sin un análisis profundo de cada uno de sus componentes.

Asimismo, desde este punto de vista se intenta estudiar el desarroIlo económico de Japón. ${ }^{55}$ En trabajos como el de Amiya Kumar Bagchi, que no insiste especialmente sobre el sistema protoindustrial como Frank Perlin (1983), se intenta explicar las causas de la desindustrialización en la India. ${ }^{56}$ De esta forma, vemos que el modelo impacta investigaciones consagradas a las áreas subdesarrolladas, como el caso de África expuesto por Gavin Kitching (1983). Se constata que el cuerpo teórico-metodológico de la protoindustrialización obtiene una gran aceptación al momento de estudiar el proceso de industrialización, por lo tanto, queda la duda de si este enfoque en su totalidad o parcialmente es útil al momento de estudiar la formación de una sociedad semiindustrializada como en el caso de México, específicamente Jalisco.

\section{6. ¿Protoindustrialización en México?}

Por el momento no contamos con todos los elementos para afirmar o negar la propuesta de Max Weber cuando dice que la industria doméstica con mano de obra no libre es vista como un fenómeno de carácter universal (Weber 1991: 184). Sin embargo, después de la proposición protoindustrial aparece un número considerable de investigaciones que dan cuenta de la existencia de ésta unidad de producción en muchos países, especialmente en Europa. Pero la simple presencia de la industria doméstica no es una garantía para el funcionamiento del sistema protoindustrial.

Por lo que concierne a México, el modelo se aplica al estudiar la proliferación de centros manufactureros, especialmente durante la

54 González Enciso (1984; 1984a); Carmona Badía (1984); Torras Elías (1984).

55 White (1989); Pauer (1991).

56 Bagchi (1976); Chaudhuri (1996). 
época colonial. ${ }^{57}$ Sin embargo, el concepto protoindustrial se utiliza indiscriminadamente, sin rigor ni análisis previo ${ }^{58}$ lo que implica pasar por alto la gama de elementos que se conjugan en este sistema, tal como aquí se expone. Asimismo, la protoindustrialización deviene un concepto cómodo para designar la etapa prefabril (Maitte 1997: 1279), pero si lo empleamos así, de ninguna forma revela las edades de la industria doméstica o del trabajo a domicilio. El reconocimiento de uno o varios elementos, por ejemplo el financiamiento de los artesanos por el comerciante (Salvucci 1992), no permite constatar o negar la existencia de la protoindustrialización en México, tanto para la época colonial como para un periodo de tiempo más reciente.

Si tomamos en cuenta que el fenómeno de la industrialización y la protoindustrialización en sí son procesos que se gestan en un contexto regional, entonces es preciso delimitar un área que nos sirva de evidencia empírica para la discusión, para ello nos apoyamos en el caso de Jalisco, aun cuando su extensión territorial rebasa las pretensiones espaciales del modelo.

Tradicionalmente, en países como México, las argumentaciones que intentan explicar el crecimiento económico se concentran obstinadamente en el contexto externo, el cual, según esta perspectiva, es capaz de condicionar completamente el funcionamiento interno del país durante los siglos XVIII y XIX, periodo conocido como de crecimiento hacia fuera sustentado en la exportación de materias primas. Otras visiones complementarias intentan buscar las causas del subdesarrollo durante la Colonia. ${ }^{59}$

Por mi parte, no estoy de acuerdo con este punto de vista en el momento de explicar el proceso de industrialización. Por ejemplo, la

57 Miño (1989; 1993); Ouweneel (1989); Thomson (1991).

58 Thomson (1989a: 62). Por lo que concierne a este punto el trabajo de Thomson (1989b: 1-62) tiene una peculiaridad interesante, es decir, a pesar de que no existe un análisis detallado sobre los elementos del sistema protoindustrial en sus trabajos, el autor afirma (1989b: 33) que para el caso de la ciudad de Puebla, entre los siglos XVII y XVIII, no se presenta una economía protoindustrial. Sin embargo, cuando expone los elementos fundamentales del sistema económico de esa ciudad y su región, se manifiesta una cierta similitud con los elementos esenciales del modelo protoindustrial, de tal forma que, aparentemente, se puede pensar que el estudio intenta poner en relieve el fenómeno de la protoindustrialización en Puebla.

59 Sunkel (1971: 4, 9, 324, 326); Ferrer (1963); Coatsworth (1990). 
economía de Jalisco no se ve directa y decisivamente influida por el comportamiento del sector externo del país durante el siglo XIX, situación que me obliga a cambiar la estrategia de análisis, al menos para este territorio. El siguiente caso es interesante al respecto.

El Ministerio de Fomento en 1877 se interesa en conocer qué se produce en distintas entidades de México, con un fin doble, en primer lugar, saber cuál es exactamente el estado que guardan las principales siembras y cosechas; en segundo lugar, pero con mayor discreción, le atraen los posibles recursos exportables. Para ambos fines se consulta al Gobierno de Jalisco, pero la respuesta que se da en la municipalidad de Chimaltitán, en el norte jalisciense a unos ocho kilómetros del pueblo minero de Bolaños (cuya mejor época se registra a finales del periodo colonial), a las inquietudes del Ministerio de Fomento es contundente: "los productos que de esta población se exportan al extranjero no hay"; $;{ }^{60}$ lo anterior muestra la peculiar situación de la agricultura, la ganadería y del sistema económico en ese lugar, incluso, este Ayuntamiento contesta que no sabía exactamente qué producto tendría éxito, después se comenta que en esa localidad se sabe de la existencia de algunas "fábricas", ¿acaso no es sorprendente la respuesta de dicho Ayuntamiento (situado en una región minera) en un país que tradicionalmente se ha tipificado de primario exportador?

Parece evidente que en un país exportador de materias primas los cambios que se producen en el contexto internacional tienen una repercusión en todas las zonas del mismo. Sin embargo, el principal problema no reside en el hecho de saber si esos espacios son o no susceptibles a dichos cambios, sino más bien saber cómo esas transformaciones influyen sobre el desarrollo económico en general y el proceso de industrialización en particular. Buscar elementos explicativos de carácter interno, situados en el tiempo y en un espacio regional concreto, puede incrementar nuestro conocimiento sobre un número considerable de factores que hasta el momento aparecen poco en las discusiones sobre el subdesarrollo económico.

Las teorías tradicionales de crecimiento y desarrollo de corte latinoamericano son negligentes sobre los aspectos internos del problema. La combinación de ambos frentes (interno y externo) es enriquecedora

60 Archivo Histórico del Estado de Jalisco (AHEJ), Secretaría de Gobierno (1878), nota, enero 21, Guadalajara, Jalisco, F-1-878 CHT/90. 
al analizar el proceso de industrialización a través del tiempo. A pesar de que las escuelas de inspiración latinoamericana, que construyen el concepto de dependencia, insisten sobre los factores históricos, al momento de responder sobre casos específicos, coherentes desde la perspectiva cronológica y de reconstrucción histórica, no fueron del todo convincentes. ${ }^{61}$

Otra perspectiva que toma en cuenta el crecimiento económico y la industrialización de países como México es la propuesta de W. W. Rostow (1962); sin embargo, presenta pocos elementos para el caso mexicano. Su esquema sufre de una interpretación lineal exagerada de los procesos, además, los argumentos son simplistas y tienden a limitar la perspectiva al no tomar en cuenta las diversas vías de la industrialización. Si consideramos las bases teóricas señaladas, al rescatar los elementos más consistentes o significativos, y las combinamos con la propuesta protoindustrial podemos aportar un pequeño grano de arena en la formación de una interpretación histórica sólida que dé cuenta de un fenómeno que se vive cotidianamente en América Latina: la dependencia.

Un estudio más concreto, como el de Manuel Miño Grijalva, utiliza la perspectiva protoindustrial cuando señala las precoces actividades manufactureras en Guadalajara y en otras partes de México (Puebla y Tlaxcala sobre todo), durante la época colonial (Miño 1989: 807). Creo que sus propuestas, sin que pierdan su originalidad, deben ser profundamente examinadas. La perspectiva protoindustrial es rica desde el punto de vista metodológico, pero insuficientemente explotada para los casos no europeos, especialmente, si vemos la industrialización como un fenómeno social que transforma los modos de vida de las sociedades inmiscuidas en el proceso, aun cuando se presente de forma incompleta.

Comparar las manifestaciones de la industrialización en los países subdesarrollados no solamente enriquece la discusión al respecto, sino que también aporta nuevos elementos de estudio sobre las naciones que adolecen de una firme base industrial, sobre todo, si se logra explicar los factores que bloquean su desarrollo o las diferencias en el atraso a través del tiempo (Maitte 1997: 1290).

61 Bernecker (1992: 11, 13, 14); Haber (1999: 1-46). 


\section{Una metodología seductora}

La propuesta protoindustrial es una caja de herramientas susceptible de emplearse para el estudio del proceso de industrialización en Jalisco durante el siglo XIX, zona delimitada en el análisis (Kriedte et al. 1986: 115), pero es importante no olvidar la herencia teórica-metodológica de las escuelas latinoamericanas. El componente geográfico es fundamental ante la diversidad regional que existe en un país como México. Delimitar el área de estudio significa reducir el problema geográfico, que para Jalisco al principio contribuye a la aparición de actividades manufactureras, pero paradójicamente después representa un obstáculo a su desarrollo. Por lo tanto, contamos con un espacio más homogéneo comparado con la escala nacional, donde los actores definen y participan en el proceso.

Gracias a la cantidad de trabajos teóricos y empíricos realizados según este esquema, que buscan explicar la transición hacia el capitalismo industrial (Ogilvie 1993: 150), es factible seguir una ruta a fin de determinar los factores que permiten a Jalisco transitar hacia una sociedad semiindustrializada. Si para los casos europeos un gran debate se abre sobre la formación de sociedades industrializadas, y si tomamos en cuenta el punto de vista de Osvaldo Sunkel al decirnos que la industrialización es igualmente parte del proceso de formación de la periferia, entonces, ¿acaso la metodología protoindustrial nos ofrece algunas explicaciones en la formación de sociedades semiindustrializadas? Seré prudente en la utilización del concepto al momento de contestar esta pregunta.

La teoría protoindustrial se desarrolla tan rápido que algunos autores detectan distintos tipos de interpretaciones desde este enfoque, sin embargo todos ellos atacan problemas cruciales para la historia y desarrollo económicos, la tendencia es la combinación de los factores mencionados, incluso, se agregan los institucionales. Cada caso de estudio da nueva luz al respecto, pero si la visión protoindustrial es capaz de explicar la diferentia specifica sobre las formas de industrialización o no industrialización de distintas regiones a través del tiempo, entonces no hablo simplemente de la protoindustrialización, sino 
de una nueva teoría del desarrollo económico con un sesgo histórico, parece que es ese el camino que se sigue actualmente. ${ }^{62}$

Por otra parte, el modelo primario exportador se concibe para un conjunto de países, o mejor dicho para casi todo un continente. Precisamente debido a su dimensión se pierden detalles trascendentes del funcionamiento económico, en ocasiones, el modelo se encuentra burdamente generalizado (Riojas 1999a: 19-54). El paradigma protoindustrial, sustentado en el análisis regional, ofrece la posibilidad de examinar con mayor precisión el proceso de industrialización, además, detecta elementos difícilmente perceptibles en un contexto nacional o continental. Entonces, un estudio detallado puede mostrar más claramente la gestación de problemas que minan el desarrollo económico.

Basado en lo anterior surge la posibilidad de hacer comparaciones desde el punto de vista histórico. Si bien es cierto que la metodología es sugestiva al encontrar en la comparación histórica una de sus principales fuentes de fascinación (Mager 1993: 184), insisto, soy prudente ya que se corre el riesgo de comparar casos incomparables. En este momento es pertinente recordar el consejo de Frank (1979: 19), cuando nos dice que numerosos investigadores abusan de la teoría marxista al basar sus explicaciones de la acumulación de capital en la periferia, veamos sus palabras:

¿Podemos simplemente transponer las categorías marxistas del interior de la metrópoli al interior de la colonia? No. Los aspirantes a marxistas que lo han hecho sólo han logrado resultados desastrosos desde el punto de vista científico y político.

No busco "transponer las categorías". A pesar de las vicisitudes de la investigación, este enfoque puede utilizarse parcial y cuidadosamente para Jalisco, quizá también para otros espacios latinoamericanos.

\section{La coherencia del modelo para el occidente de México en el siglo XIX}

Al estudiar la historia económica de Guadalajara durante la época colonial tardía, así como su influencia territorial que engloba buena parte del actual Jalisco, detectamos elementos y características similares a las zonas protoindustriales europeas de los siglos XVIII y XIX.

62 Sabel/Zeitlin (1985: 139, 141); Ogilvie (1993: 160); Pfister (1996: 73). 
Por ejemplo, una sociedad agraria avanzada, presencia de producción manufacturera, crecimiento demográfico continuo, aumento en la difusión de tareas productivas, avances técnicos modestos, paulatina formación de trabajadores agrícolas y artesanos pagados con moneda, y en menor medida una especialización regional. ${ }^{63}$

Sin embargo, ¿cuáles son las tendencias que siguen estas características de Jalisco y su evolución durante el siglo XIX? ¿Cuáles son las transformaciones que impiden un proceso completo de industrialización? ¿Qué tipo de articulación se establece entre las actividades productivas? ¿Acaso hablamos de una zona protoindustrial o solamente el modelo nos brinda explicaciones parciales sobre los fenómenos que originan una sociedad semiindustrializada?

Como demuestro en otras investigaciones (Riojas 1999b; 2003), Jalisco durante el siglo XIX no es una zona agrícola directa y fundamentalmente ligada a una región industrial de México. A pesar de que se producen materias primas, encontramos bastantes actividades que tienen relación con el interior del estado, especialmente en torno a la ciudad de Guadalajara, al trabajar parcial o totalmente los insumos respectivos. Lo anterior influye en la definición de una identidad cultural con respecto al uso de recursos naturales, humanos y técnicos (Hudson/King 1996: 183). El caso de los molinos ubicados en los alrededores de Guadalajara, así como sus múltiples conexiones, son un buen ejemplo de ello, especialmente si tomamos en cuenta dos fenómenos. En primer lugar, la creciente demanda de alimentos que implica un aumento demográfico continuo entorno a la ciudad; y en segundo lugar, el grado de comercialización de la agricultura que se articula con otras actividades económicas. Veamos algunos casos.

En la primavera de 1892 el molino de El Salto pertenece a los hermanos Fernández del Valle, quienes usan como transporte hacia Guadalajara las plataformas de la Compañía de Tranvías, pero dicho tráfico esta sujeto a un impuesto, lo que motiva a los Fernández del Valle a proponer un pago basado en una "iguala". Para tal efecto plantean un acuerdo al Ayuntamiento, "en donde ni el municipio ni ellos saldrían perjudicados", al sugerir pagar a la Tesorería 80 pesos men-

63 Kriedte et al. (1986: 45, 63); Dewerpe (1984: 902); Riojas (2000); Brading (1993); Van Young (1989); Becerra (1994); Calvo (1993); Lindley (1987); Serrera (1991). 
suales por la entrada y salida diaria de cuatro carretas o carros con dos ruedas, si algún día no cumplen con esta disposición, al final del mes se calcula el promedio respectivo, en caso de exceso pagan la proporción correspondiente, de lo contrario los 80 pesos pactados. Se recurrió a la legislatura local para la autorización del convenio. ${ }^{64}$ Otros casos parecidos al anterior se presentaron en ese mismo año. El administrador del molino El Salvador, el comerciante Daniel Galíndez, solicita en septiembre al Ayuntamiento de Guadalajara la exoneración de la cuota municipal, porque la mayoría del trigo que recibe procede de la estación del Ferrocarril Central en Guadalajara, mientras que el establecimiento se encuentra precisamente del otro lado de la ciudad, entonces, el cargamento tiene que atravesar la capital dos veces para procesarse y venderse. Mientras que los molinos situados en los límites de la ciudad no pagan ese impuesto -argumenta Galíndez-, por tanto, pide que sus productos tampoco lo paguen para hacer frente a la competencia. ${ }^{65}$ Un caso más se presenta en abril, Francisco Ramírez Monrroy, antiguo munícipe de Guadalajara y administrador del molino El Refugio, pide igualdad de condiciones con respecto al molino de Piedras Negras, por lo que solicita la exoneración que cobra el municipio por cada carreta que entra a la ciudad rumbo a El Refugio. Ramírez sabe que el administrador de Piedras Negras no paga el impuesto de "derecho de piso", solo da un peso mensual por marcar sus carretas que transportan la materia prima, pero se ha abstenido de presentar tal petición "por la delicadeza personal en tanto que fungía como Munícipe" ${ }^{66}$ En este caso la gestión de Ramírez dio resultados, gracias a los vínculos que mantiene con la élite política local, que estaba a su vez ligada con la económica. A principios del siglo XIX los molinos están fuera de la ciudad, cuando los absorbe el crecimiento urbano, su situación tributaria cambia. Las transformaciones en el uso del espacio se vinculan con los intereses específicos de actividades económicas que se consolidan. Finalmente, está el ejemplo del molino de trigo Montenegro, la legislatura estatal dispone en 1892 que este molino situado al norte de Guadalajara se considerará dentro de sus límites y pagará los impuestos municipales correspondientes; a finales de 1893 su adminis-

64 Archivo Histórico Municipal de Guadalajara (AHMG), Hacienda, 23 de abril de 1892, exp. 21.

65 AHMG, Hacienda, 21 de septiembre de 1892, exp. 51.

66 AHMG, Hacienda, 8 de octubre de 1892, exp. 55. 
trador Rosalío Ruíz solicita al Ayuntamiento la pensión estimada de tercera clase por tres meses para reducir gastos. ${ }^{67}$

Pero la ausencia de un estudio sobre las regiones, que se forman en el occidente mexicano durante el siglo XIX, nos impide saber qué tipo de interdependencia regional existe, así como la evolución o las rupturas en la localización productiva. ${ }^{68}$ Eventualmente, se manifiesta una especialización y una división del trabajo, pero solamente una investigación específica nos dirá cómo funciona el mecanismo que da nacimiento a este fenómeno, sobre todo a nivel intrarregional e interregional.

En el periodo de estudio encontramos algunas características históricas y socioeconómicas que coinciden con los principios básicos de funcionamiento del modelo protoindustrial, ejemplo de ello es una avanzada comercialización de la agricultura, manifestada en las actividades de los molinos. Pero existe otra cantidad considerable de aspectos determinantes que ignoramos o que falta estudiar profundamente, donde destacan las siguientes preguntas: ¿acaso se manifestó un modo de producción familiar en Jalisco durante el siglo XIX o cuál es el papel de cada uno de los miembros de la familia en las unidades productivas? Si encontramos un parámetro para medir la productividad, ¿cuáles son los mecanismos que permiten el crecimiento continuo de la productividad o, en su defecto, que lo impiden? ¿Cuál es el impacto de las transformaciones técnicas o tecnológicas en la organización general de la producción? Además, temas como los anteriores son difíciles de tratar con la precisión requerida ya que dependemos de las fuentes documentales.

De acuerdo con la investigación hecha hasta el momento, creo que se manifiesta una serie de factores que nos impiden afirmar la existencia de un modo de producción protoindustrial en Jalisco durante el siglo XIX. Si partimos de las evidencias empíricas conocidas, el modelo comienza a perder coherencia en el espacio que estudio, entonces, es importante dar mayor peso a las primeras con el fin de no injer-

67 AHMG, Hacienda, 8 de octubre de 1892, exp. 55; 7 de octubre de 1893, exp. 14.

68 Es interesante señalar que en Europa, más que una evolución, se ha insistido sobre una ruptura espacial en la localización de las antiguas zonas protoindustriales del siglo XVIII y XIX, con respecto a los emplazamientos industriales del siglo XX. Leboutte (1996a: 266); Mager (1993: 203). 
tar formas de análisis preestablecidas, difíciles de sustentar en un estudio histórico concreto. ${ }^{69}$ Veamos tres ejemplos al respecto.

Primero, entre las particularidades del modelo clásico, el campo juega un papel más activo con respecto a la ciudad. Para el caso de Jalisco en el siglo XIX, lo anterior es cuestionable, incluso, los papeles se invierten. Las diferentes actividades realizadas en la zona de influencia de Guadalajara - donde se incluye una buena cantidad de tareas artesanales, manufactureras así como fabriles- son primordiales para el crecimiento económico y demográfico del occidente mexicano, la articulación recíproca con las tareas del campo se manifiesta en múltiples formas. Además, la inestabilidad general de la centuria hace que muchos actores rurales busquen refugio en la ciudad, lo que hace aún más patente el vínculo entre el campo y la ciudad. Esta situación no es exclusiva de México. ${ }^{70}$ En este contexto, una vez más las actividades de los molinos resultan un buen ejemplo, ya que éstos funcionan casi durante toda la centuria, incluso su importancia y cantidad se incrementan con el devenir del tiempo. No solamente las actividades en la ciudad de Guadalajara se articulan con su entorno rural, en otras pequeñas ciudades parece que surge algo similar. Otro ejemplo de esta situación se encuentra en 1847 cuando Joaquín Angulo, gobernador de Jalisco en ese entonces, sabe de la importancia del medio rural e insiste desde Guadalajara en promover tanto la agricultura como la "industria" ${ }^{71}$ (entiéndase por esta última talleres artesanales, manufacturas y algunas fábricas instaladas en las orillas de la capital del estado). Todavía más atrás, junto a los no abundantes cultivos de tabaco en Jalisco, Ignacio Cañedo el 7 de mayo de 1831 informa con detalle al gobernador de la entidad que en la última semana se habían labrado 20 cajetillas de puros y 3.968 cajillas que se despacharon a distintos lugares: para Autlán tres cajones de puros y siete de cigarros, para Tequila cuatro de puros y siete de cigarros, para Zapotlán dos cajas

69 Maitte (1997: 1294, 1302) nos advierte sobre esta limitante del modelo protoindustrial al estudiar el caso de Prato, Italia.

70 Evidencias empíricas contrarias a las predicciones del modelo también se registran en Europa. Delon (1999: 38); Hendrickx (1993: 329, 330); Hohenberg (1996: 196, 210); Kriedte et al. (1996: 47); Hudson/King (1996: 196, 210); Ogilvie (1993: 163).

71 AHEJ, Angulo, Joaquín (1847): Memoria sobre el estado de la administración del Estado de Jalisco, presentada el $1 .^{\circ}$ de septiembre, p. 7. 
más de cigarros ${ }^{72}$ así, es considerable el mercado que abastece Cañedo desde su hacienda cercana a Ameca. Estos casos se pueden multiplicar y corroboran la crítica hecha, pero los ejemplos que sirven de base a los siguientes puntos también refuerzan este primero.

Segundo, las modalidades de penetración del capital comercial en la esfera de la producción no son suficientemente conocidas y estudiadas en Jalisco durante el período en cuestión. Cuando esta relación se detecta, el control de la producción corre por cuenta de varios agentes que difícilmente caben en la clasificación de un marco teórico específico, por ejemplo el Verlagssystem. Así como puede tratarse de un comerciante, también puede ser un religioso o un hacendado quienes penetran o mantienen contacto con la esfera de la producción. Incluso, en la investigación histórica esta relación no es muy clara, a pesar de la existencia de supuestos "habilitadores, aviadores o fiadores" (Miño 1989: 808). Pero su incapacidad para financiar la producción masiva de manufacturas es más evidente, a ello es necesario agregar un contexto económico y social inestable. El hecho de identificar uno o dos agentes similares a los descritos por el modelo no basta, quizá podamos ir más allá en nuestro intento por explicar un proceso de industrialización incompleto si estudiamos las instituciones de la estructura social que dan nacimiento a estos personajes y a sus estrategias, sin apegarnos estrictamente a la cadena Kaufsystem-VerlagssystemFactory System. $^{73}$

El siguiente ejemplo es revelador en cuanto a las especificidades entre las relaciones de comerciantes y artesanos, las cuales difícilmente se engloban en la tipología propuesta por el modelo, sobre todo si se toma en cuenta que este tipo de vínculo fue inconsistente a través del tiempo. En noviembre de 1869 se reúnen en la ciudad de Guadalajara los artesanos de la rebocería y lana con los "comerciantes de efectos del país" para establecer acuerdos equitativos sobre el tipo de relaciones que mantienen, José Palomar es el comisionado y mediador oficial por parte del Gobierno de Jalisco. Según el comerciante Antonio Álvarez del Castillo, el problema radica en las situaciones particulares de cómo se realiza el comercio con los artesanos, fundamentalmente en

72 AHEJ, oficio, 1831, mayo 7, Guadalajara, Jalisco, F-9-831 GUA/1070.

73 Kriedte et al. (1993: 226); Leboutte (1996b: 6); Pfister (1996: 86); Sabel/Zeitlin (1985: 151); Ogilvie (1993: 176); Van der Wee/D’Haeseleer (1996: 261, 162). 
dos frentes. El primero de ellos es la competencia que sufren de otros centros artesanales ubicados en el occidente del país, donde destacan León, Zamora y otros pueblos del Bajío, lo cual le resta mercado a los productos elaborados en Guadalajara, a ello es necesario agregar la competencia de productos extranjeros. El segundo frente corresponde a los continuos disturbios político-militares que minan las bases fundamentales del comercio, tanto de la oferta como de la demanda. Pero lo más importante para nosotros son las formas de comercialización, debido a que los comerciantes hacen sus "compras á los artesanos dándoles su valor en efectos y dinero", pero no hay indicios de que se trate de un capital adelantado o una habilitación, sino que la falta de numerario, la inconsistencia del mercado al momento de conseguir la materia prima o vender el producto, así como la competencia nacional y extranjera hacen que se realice la transacción con ese tipo de condiciones. Lo anterior toma mayor importancia cuando el señor Jesús García dice, en la misma reunión, que

entre los maestros de los talleres de rebocería hay un abuso que diariamente, cometen [...] pagan a sus oficiales con hilo á un precio elevado donde resulta que este al venderlo tiene que darlo a un valor que no compensa á su trabajo. ${ }^{74}$

De esta forma, se detecta que no existe una sola modalidad en el contacto entre los artesanos y los comerciantes aceptada cabalmente por ambos, los primeros pretenden pagar a los artesanos con mercancías a fin de incrementar sus ganancias, pero no se trata de un adelanto de materias primas como el Verlagssystem, mientras que los segundos buscan obtener dinero con el fin de hacer frente a la compra de materia prima o pagar a sus trabajadores. ${ }^{75}$

Asimismo, presento otro caso pero vinculado con la producción y comercialización de aguardiente (tequila y mezcal). En octubre de 1877, el tequilero don Aurelio Martínez y los hermanos Gorjón formalizan un contrato para producir aguardiente y comercializarlo en Gua-

74 AHEJ, acta, 1869, noviembre 7, Guadalajara, Jalisco, F-9-869 GUA/855.

75 El pago en especie se denuncia por la Compañía de Artesanos de Guadalajara desde 1850, cuando se hace especial hincapié en el caso de los reboceros. Biblioteca Pública del Estado de Jalisco (BPEJ), Compañía de Artesanos de Guadalajara (1850): "Reglamento de la Compañía de Artesanos de Guadalajara", Miscelánea, núm. 327, Imprenta de Manuel Brambila, Guadalajara, Jalisco, p. 3. Al igual que en 1869 , no se identifican elementos que apoyen la hipótesis de un Verlagssystem. 
dalajara por un término de dos años, los Gorjón reciben 2.000 pesos por parte de Martínez a fin de vender y comprar tequila en la capital del estado, así quedan obligados "a comprar de preferencia" la bebida remitida por el mismo Martínez y, por otro célebre tequilero, don Cenobio Sauza a precios corrientes, siempre y cuando las partidas no rebasen la capacidad financiera de los Gorjón, de las utilidades obtenidas por éstos últimos a don Aurelio Martínez le corresponde un cinco por ciento, el cual tiene la facultad de examinar los respectivos libros contables para determinar si continúa o no en el negocio. El sobrino de Sixto Gorjón, don Ramón Zúñiga, podrá auxiliar a su tío en los asuntos relacionados con la comercialización del tequila en Guadalajara. ${ }^{76}$ Este tipo de asociaciones a partir de la segunda mitad del siglo XIX en Jalisco son típicas, tanto en la comercialización del tequila como en otros rubros de la actividad económica, además, constituyen una muestra de la asociación de tequileros con comerciantes para penetrar el mercado de Guadalajara. Pero, aquí se da una situación interesante, normalmente dentro de los estudios sobre protoindustrialización revisados en este trabajo, el comerciante financia al productor como parte del Verlagssystem, en este caso sucede lo contrario, el productor de tequila habilita con recursos financieros al comerciante, lo cual nos habla del poder económico de los tequileros, así como de las especificidades de la organización de la producción en Jalisco. Cabe mencionar que la producción de tequila es una de las pocas actividades económicas de la entidad que logran un proceso exitoso de industrialización con penetración en mercados internacionales.

Tercero, la comercialización de la producción es crucial. Generalmente, en Jalisco durante el siglo XIX, los establecimientos de actividades manufactureras venden casi toda su producción en los mercados locales, esporádicamente lo hacen en los regionales, sin que éstos últimos sean la raison d'être de dicha producción. En ello influyen la integración con otros establecimientos, la eficiencia y la flexibilidad de las técnicas de producción. Es precisamente desde este ángulo donde encuentro una ruptura con los criterios esenciales de la protoindustrialización; es decir, la comercialización de la producción en los mercados regionales o internacionales. En ambos casos el mercado juega

76 Archivo de Instrumentos Públicos del Estado de Jalisco (AIPEJ), notario Onofre Valdez, 13 de octubre de 1877, vol. IV, fols. 10v.-11v. 
un papel importante, pero sus efectos toman caminos contrarios para el caso de Jalisco. Asimismo, la influencia de otros mercados, especialmente de alimentos, es clave en el sustento de personajes como los artesanos, quienes están sujetos a los cambios inesperados de la oferta, mientras que la demanda se ve influida por la configuración de los precios relativos. $^{77}$

El ejemplo de la Compañía de Artesanos de Guadalajara en 1850 sirve para corroborar lo manifestado en este punto, donde también son evidentes los problemas de comercialización, incluso en su misma localidad; pero dicha situación no es exclusiva de Guadalajara, en otras poblaciones de la entidad se presentan dificultades similares. En 1880, en la municipalidad de Sayula, donde nuestro testigo consideraba que la agricultura no es el ramo de primer orden, se practica una rotación de cultivos, se reserva una tercera parte de los terrenos para cosechar la caña de azúcar, magueyes, árboles frutales, fríjol, cebada y legumbres; otra tercera parte es dedicada al maíz, mientras que el resto se deja descansar; pero en el número de habitantes en esa municipalidad los artesanos tienen un peso proporcional importante al compararse con los jornaleros o campesinos. ${ }^{78}$ A pesar de ello, los artesanos llevaban varios años sufriendo algunos problemas para llevar a cabo la comercialización de su producción en las localidades aledañas. En 1869, Antonio E. Naredo, vecino de Sayula, encabeza una reunión para apoyar a los artesanos de Teocuitatlán de Corona, poblado cercano a Sayula, ante los problemas que los aquejan; según él, sobresale una constante falta de numerario, escasa protección a las artes (producción manufacturera) nacionales por parte del Gobierno y un desprecio por los artículos elaborados por los mexicanos. Más que una competencia netamente mercantil, Naredo considera que existen algunos prejuicios con respecto a la producción manufacturera:

$[\ldots]$ lo estrangero [sic] se creé superior a lo nacional y el nombre de mejicano es muy mala recomendación, y por último que mal recibida la industria nacional, los pobres artesanos se ven en la dura necesidad de cru-

77 Chaudhuri (1996: 112); Ogilvie (1993: 166); Sabel/Zeitlin (1985: 135, 174); Van der Wee/D'Haeseleer (1996: 261); Pfister (1996: 178).

78 BPEJ (1880) "Cuadro general estadístico de la municipalidad de Sayula", Miscelánea, núm. 327, Tip. De Banda Exconvento de Santa María de Gracia, Guadalajara, Jalisco, pp. 20, 21, 28. 
sarce [sic] de manos y morir en la desesperación y de miseria, sufriendo los sarcasmos y la indiferencia de los que los rodean $[\ldots]{ }^{79}$

Con el fin de reducir algunos problemas para la comercialización y minar la competencia de las manufacturas extranjeras en ese lugar, se propone en la reunión tres medidas: usar prendas de vestir de origen nacional y reducir en todo lo posible las extranjeras con el objetivo implícito de sustituirlas, especialmente aquellas de lino; traer siempre alguna ropa de origen nacional, mientras que las de origen extranjero se usarán hasta que queden inservibles; y a la persona que se sorprenda con una prenda de origen extranjero le será confiscada y vendida de inmediato, el dinero que se obtenga de dicha confiscación servirá para ayudar a los artesanos pobres. Lo anterior nos muestra algunos problemas de comercialización en Jalisco, además, si las áreas protoindustriales en Europa se benefician del comercio internacional, en Jalisco este tipo de comercio mina seriamente las posibilidades de los artesanos oriundos, pero no por ello desaparecen.

Las pequeñas unidades de producción se encuentran en el centro del debate, independientemente de los problemas que enfrentan en el transcurso del siglo XIX. Algunas de ellas son relacionadas con economías atrasadas donde predomina una fragmentación de la propiedad y un ejército de pequeños propietarios pobres, lo que eventualmente impide la transición hacia la industria manufacturera moderna. También son vistas como una forma de industrialización difusa, con cierta flexibilidad y adaptabilidad a condiciones adversas, lo que no les impide alcanzar estándares de calidad que difícilmente las fábricas logran. Independientemente de la postura interpretativa, lo crucial para el proceso de industrialización es la formación de una economía más diversificada y una cultura de cambio técnico permanente. ${ }^{80} \mathrm{Si}$ en un momento la historia industrial pretende liquidar las pequeñas unidades de producción ante el dominio de la gran industria, ahora es necesario tomarlas en cuenta con una perspectiva de largo plazo, ya que demuestran una vez más su persistencia en un contexto de transformaciones técnicas y tecnológicas vertiginosas, la coexistencia parece ser más la regla que la excepción en distintos ramos industriales. ${ }^{81}$

79 AHEJ, Naredo E., Antonio et al. (1869), acta, Sayula, Jalisco, F-9-869 TEC/851.

80 Ciriacono (1996: 317-318); Kriedte et al. (1996: 66, 69); Leboutte (1996a: 289); Pfister (1996: 76); Lewis (1994: 158); Ogilvie (1993: 165).

81 Mager (1993: 203); Kriedte et al. (1993: 232; 1996: 70, 71). 
Si pensamos en una historia lineal de las pequeñas unidades de producción, se distinguen varios tipos, que no necesariamente corresponden a un modo de producción protoindustrial donde se mezclan las estructuras agrarias (Mager 1993: 188). El primero de ellos es una fase de transición hacia el sistema fabril basado en una especialización flexible, el segundo, la última etapa de un modo de producción moribundo ante el auge del sistema capitalista de producción y el tercero, la forma moderna de la producción descentralizada. Sin embargo, no siempre el punto de vista lineal refleja lo que nos marca la evidencia empírica (Kriedte et al. 1996: 62, 63; 1993: 234-238). La situación de Jalisco, donde las pequeñas unidades de producción tienen profundas raíces históricas, no se inscribe estrictamente en ninguno de los tipos mencionados, la coexistencia persiste debido a que las fábricas no toman una ventaja decisiva desde el punto de vista técnico, por lo tanto, parece que las primeras continúan su larga trayectoria con formas flexibles de organización productiva y rebasan la era postindustrial (Sabel/Zeitlin 1985: 156), lo que se concibe difícilmente en modelos panexplicativos. Ejemplos de lo anterior se encuentran para 1882 en Santa Anna-Acatlán, donde sus habitantes se ocupaban en general en la siembra de maíz, trigo y cultivo de caña de azúcar, también elaboraban piloncillo, además, se sabe de ocho carpinterías, dos herrerías, un número no determinado de zapaterías, carrocerías, sastrerías y talabarterías, también dos molinos de harina y nueve trapiches donde se hace el citado piloncillo; en Zacoalco de Torres se da una situación similar. Asimismo resulta interesante el caso de Teocaltiche, municipalidad de Paso de Sotos en 1887, donde además de las actividades agrícolas se menciona la existencia de tres talleres de carpintería y dos de sastrería "establecidos en muy pequeña escala, pues sólo dan ocupación temporadas cortas, á 6 carpinteros, 4 sastres, 2 herreros, 6 zapateros, 4 curtidores [...]". ${ }^{82}$ Aquí encuentro dos puntos interesantes por comentar, el primero de ellos es el contexto agrícola que permite el nacimiento y persistencia de estas actividades en las áreas rurales, el segundo, concierne a las formas de organización, especialmente la alternancia entre la agricultura y las actividades artesanales o manufactureras.

82 AHEJ, Secretaría de Fomento, Colonización, Industria y Comercio (1887), expedientes, Jalisco, F-9-887 JAL/103. 
De acuerdo con los perfeccionamientos de la propuesta protoindustrial, sus creadores mencionan que no se trata de un modelo estricto, sino de un conjunto de hipótesis articuladas. Además, se reconoce la existencia de diversos tipos de protoindustrialización, ${ }^{83}$ lo que abre la puerta a numerosas investigaciones usando este marco. Por lo que concierne a América Latina, se propone un "tipo" de protoindustrialización para la Nueva España (Miño 1989: 803; 1993: 18, 51); sin embargo, creo que al encontrar distintos tipos, al menos deben existir principios comunes que permitan determinar cuál fenómeno es protoindustrial y cuál no. Por lo tanto, señalar la simple presencia del trabajo doméstico, en el campo o la ciudad, no significa que hablemos automáticamente de protoindustrialización, sobre todo cuando las unidades productivas pertenecen a distintas ramas productivas y poseen naturalezas específicas a través del tiempo. ${ }^{84}$

Si bien es cierto que se detectan elementos importantes para hablar de un funcionamiento del sistema protoindustrial en México, no menos cierto es que son insuficientes para definirlo como tal, aun si consideramos que existen diversos tipos de protoindustrialización. Si partimos del supuesto de que la protoindustrialización es The First Phase, la etapa siguiente puede ser la industrialización o desindustrialización; sin embargo, Jalisco no se industrializa completamente, tampoco sufre un proceso de desindustrialización, entonces, este espacio no encuentra cabida en dicha dicotomía. Ante tal problemática se abren otras posibles categorías de análisis como la formación del distrito industrial, por ejemplo (Maitte 1997: 1290).

Pero ¿qué respuesta nos da el modelo? ¿Es necesario analizar todos los procesos de industrialización desde esta perspectiva teórica? ¿Acaso dejaremos de lado un mundo de posibilidades en los procesos de industrialización? ¿Es indispensable la etapa protoindustrial en cualquier tentativa de industrialización? La diferenciación entre cada uno de los casos es clave para entender el proceso de industrialización de México en general y el de Jalisco en particular. Una serie de análisis profundos de las diferentes regiones del país posibilita determinar la pertinencia o no pertinencia del enfoque protoindustrial, así como las especificidades de los casos mexicanos.

83 Kriedte et al. (1986: 300, 301); Deyon/Mendels (1981: 16).

84 Hudson/King (1996: 183); Kriedte et al. (1993: 218, 219, 232); Mager (1993: 118). 
Tradicionalmente, cuando se aborda la problemática general de la industrialización en México, y en particular la de Jalisco durante el siglo XIX, se exagera al aplicar una visión clásica del proceso de industrialización (Cardoso 1980b: 155-156), ${ }^{85}$ basada en la formación de unidades productivas a gran escala como la única vía factible. Las otras unidades productivas, especialmente las pequeñas, son vistas como los últimos signos de un modo de producción decadente y condenadas a la desaparición ante el advenimiento de la gran industria. Como respuesta a dicha interpretación se tiene un mundo de posibilidades en el proceso de industrialización, donde se hace hincapié en múltiples formas de estructuración y organización productiva, en las cuales las fábricas y la mecanización generalizada están lejos de dominar el panorama manufacturero. La proliferación de pequeñas unidades de producción no implica necesariamente la imposibilidad de lograr un crecimiento económico continuo, al menos lo anterior se ha demostrado en el caso de Prato en Italia, donde la flexibilidad, la capacidad de responder a cambios bruscos en la demanda y la estrategia para reducir costos, impulsan una particular dinámica local. Por lo tanto, el modelo como simplificación de lo general en un momento determinado nos ayuda a comprender ciertas características del fenómeno, pero también nos limita al estudiar una evidencia empírica en particular. $^{86}$

La aparición tardía de la gran industria en Jalisco sorprende a especialistas que no toman en cuenta la existencia de varias vías en el proceso de industrialización. Incluso, algunos juzgan el caso de México como un fracaso (Bernecker 1992: 23), o hacen caso omiso del proceso histórico en su conjunto (Salvucci 1992: 98). Si consideramos

85 Cardoso (1980b: 155-156) se pregunta sobre la pertinencia en la utilización de conceptos marxistas para el caso mexicano y latinoamericano, así como la presencia de un proceso sui generis en México. No obstante, creemos que Cardoso (1980a: 15-17, 36-61) exagera al recurrir a una visión clásica de la industrialización. Sobre esta misma exageración, ver Olveda (1991: 139); Beato (1985: 190).

86 En la discusión sobre Prato encontramos una analogía con el caso de Jalisco en cuanto a la proliferación de pequeñas unidades de producción. Sin embargo, es necesario ser prudente en la comparación, así como reducir la escala de análisis en este último caso, según las recomendaciones personales de Alain Dewerpe, para dar cuenta de una forma más clara sobre las especificidades del caso de estudio y poder compararlas con las propuestas de la protoindustrialización. Maitte (1997: 1275, 1276, 1278-1281, 1292); Ogilvie (1993: 162); Chaudhuri (1996: 111); Sabel/Zeitlin (1985: 137, 138). 
la reflexión de Sunkel (1971: 66), quien nos recuerda que cada caso o país posee circunstancias y factores históricos específicos que permiten caracterizar el fenómeno, entonces ¿podemos reducir el marco analítico de esta sugerencia y considerarla para Jalisco? Precisamente desde esta perspectiva propongo estudiar las causas que permiten la formación de una sociedad semiindustrializada, donde doy prioridad a los factores internos que se manifiestan más tarde en una dependencia económica profunda. La persistencia en el contexto manufacturero de pequeñas unidades de producción a nivel local, incluso regional, no es tomada en sus reales dimensiones (Haber 1992: 21), fundamentalmente debido a las complicaciones para medir su verdadero impacto en la macroeconomía del país.

En un trabajo de Carlos Alba (1987), realizado para Jalisco en el siglo XX especialmente, se encuentra un punto de vista atractivo sobre los problemas conceptuales del trabajo a domicilio. Pero este autor solamente cita trabajos clásicos, ya que su intención no es presentar una perspectiva histórica más amplia, y uno se cuestiona sobre el nacimiento de este tipo de unidades productivas en la entidad. Desde tiempos coloniales se conocen casos de personas interesadas en impulsar las actividades manufactureras, pero que se someten constantemente a los intereses mercantiles, los cuales tienen una larga tradición en el área (Lindley 1987: 124). Además, como en otros contextos caracterizados por su atraso relativo (Maitte 1997: 1278, 1298), la inversión de capital fijo en las actividades manufactureras no es considerable.

Entonces, a partir de lo argumentado aquí, considero el enfoque protoindustrial como una caja de herramientas que me ayuda a comprender mejor el proceso de formación de una sociedad semiindustrializada, pero de ninguna forma busco encasillar la experiencia de Jalisco en este esquema, el cual no es más que una buena referencia teórica para mis reflexiones. Deyon/Mendels (1981: 247) creen que el modelo es pertinente para explicar los problemas de los países subdesarrollados, lo anterior se manifiesta más claramente en la segunda generación de trabajos (Ogilvie 1993: 175, 177). Pero los resultados son pobres hasta el momento. Entonces, dejo abierta una agenda de investigación sobre el proceso de industrialización de Jalisco durante el siglo XIX, que incluye aspectos institucionales, de demografía histórica, historia agrícola y campesina, consolidación de mercados, etc. 


\section{Consideraciones finales}

La revolución industrial se considera el fenómeno que da origen a las sociedades modernas, mucho se insiste en si es una verdadera revolución o si es un proceso gradual que se gesta a través del tiempo. Sin embargo, lo que conocemos como revolución industrial es un proceso irreversible y determinante para la historia económica. Las aproximaciones teórico-metodológicas que estudian este suceso son variadas, en particular me intereso por la visión protoindustrial. En los trabajos clásicos se descubren paulatinamente muchos factores socioeconómicos que influyen en la formación de sociedades industrializadas, análisis particulares de éstos arrojan nueva luz al respecto. Asimismo, surgen otras interrogantes.

El modelo protoindustrial intenta explicar cuáles son las causas de la revolución industrial y cómo se conjugan para dar como resultado una sociedad industrializada. Pero a partir de los factores explicativos que guardan cierta relación entre sí, creo que se pueden establecer criterios para explicar la formación de sociedades semiindustrializadas. La propuesta protoindustrial tiene una buena aceptación a nivel internacional, existe una copiosa literatura sobre los espacios que viven un proceso de industrialización exitoso, pero para experiencias no exitosas hay pocas referencias. Precisamente este último resultado me interesa.

En un principio se piensa que el fenómeno de revolución industrial es exclusivo de los países que lograron industrializarse, pero ¿por qué no pensarlo como un proceso que se manifiesta en otras sociedades con resultados distintos e irreversibles a los tradicionalmente conocidos? ¿Por qué no tomar en cuenta todos los factores explicativos del enfoque protoindustrial para explicar la industrialización parcial o precoz de los espacios subdesarrollados?

Por lo que toca a México, la simple presencia de unidades domésticas o pequeñas unidades de producción no garantiza el funcionamiento protoindustrial, pero tampoco su negación. Basándose en los estudios realizados con este enfoque, fundamentalmente para el periodo colonial, considero que se usa deliberadamente el concepto. Insisto sobre este punto de vista, el contacto entre artesanos y comerciantes no nos permite refutar o aceptar la presencia de la protoindustrialización en México aun si extendemos el periodo de análisis. Sin embar- 
go, lo más importante es conocer las consecuencias de este tipo de relaciones para el proceso de industrialización en su conjunto. Cuando se pretende estudiar la industrialización de espacios como Jalisco, las respectivas teorías no responden satisfactoriamente al momento de analizar las evidencias empíricas, tampoco lo hace la protoindustrialización, pero sí encontramos elementos que nos ayudan a ir más allá sin apegarnos a los criterios estrictos del modelo.

Se menciona la presencia de la protoindustrialización para la Guadalajara colonial, no obstante para este espacio, y sobre todo para el siglo XIX, no existe una amplia gama de investigaciones históricas que nos permitan hablar del funcionamiento de dicho esquema en el área. La metodología protoindustrial es seductora, sin embargo quiero ser prudente en su utilización, la concibo como una caja de herramientas, gracias a la cantidad de factores que contempla y que pueden ser esclarecidos con un enfoque de teorías del desarrollo. Así, queda abierta una agenda de investigación histórica con el fin de explicar los posibles factores que intervienen en la formación de las sociedades semiindustrializadas.

\section{Bibliografía}

Alba Vega, Carlos (1987): La petite industrie et les entrepreneurs dans une société dépendante. Le cas de Guadalajara, Mexique. Tesis de 3ème cycle. Paris: EHESS.

Ashton, Thomas S. (1983): La revolución industrial, 1760-1830. México, D.F.: Fondo de Cultura Económica.

Bagchi, Amiya Kumar (1976): "Deindustrialization in India in the $19^{\text {th }}$ Century. Some Theoretical Implications". En: Journal of Development Studies, 12, 2, pp. 135-164.

Bairoch, Paul (1983): "La agricultura y la Revolución Industrial 1700-1914”. En: Cipolla, Carlo M. (ed.): Historia económica de Europa, vol. 3: La Revolución Industrial. Barcelona: Ariel, pp. 464-516.

- (1990): "Développement". En: Greffe, Xavier/Mairesse, Jacques/Reiffers, JeanLouis (eds.): Encyclopédie Économique, vol. 2. Paris: Economica, pp. 133-175.

Beato, Guillermo (1985): "Jalisco. Economía y estructura social en el siglo XIX". En: Cerutti, Mario/Sindico, Domenico (eds.): El siglo XIX en México. Cinco procesos regionales: Morelos, Monterrey, Yucatán, Jalisco y Puebla. México, D.F.: Claves Latinoamericanas, pp. 149-199.

Becerra, Celina G. (1994): "Rancheros en los Altos de Jalisco en la época colonial". En: Barragán López, Esteban, et al.: Rancheros y sociedades rancheras. México, D.F.: CEMCA. 
Belfanti, Carlo Marco (1993): "Rural Manufactures and Rural Proto-Industries in the 'Italy of the Cities' from the Sixteenth through the Eighteenth Century". En: Continuity and Change, 8, 2, pp. 253-280.

Berg, Maxine (1996) "New Consumer Industries in Eighteenth-Century England. Products, Markets and Metal Goods in Birmingham and Sheffield". En: Leboutte, René, pp. 211-236.

Bergeron, Louis (1984): "French Industrialization in the Nineteenth Century. An Attempt to Define a National Way". En: Proceedings of the Annual Meeting of the Western Society for French History, 12, pp. 154-163.

Bernecker, Walther L. (1992): De agiotistas y empresarios. En torno de la temprana industrialización mexicana (Siglo XIX). México, D.F.: Universidad Iberoamericana.

Brading, David A. (1993): Mineros y comerciantes en el México Borbónico (1763-1810). México, D.F.: Fondo de Cultura Económica.

Braudel, Fernand (1979): Civilisation matérielle, économie et capitalisme XVe-XVIIIe siècle, vol. 1: Structures du quotidien; vol. 2: Les jeux de l'échange; vol. 3: Le temps du monde. Paris: Armand Colin.

Cailly, Claude (1993): "Contribution à la définition d'un mode de production protoindustriel". En: Histoire et Mesure, 8, 1/2, pp. 19-40.

Calvo, Thomas (1993): "Un marché monétaire. Guadalajara au XVIIe siècle". En: Chamoux, Marie-Noëlle, et al. (eds.): Prêter et emprunter. Pratiques de crédit au Mexique, XVTe-XXe siècle. Paris: Maison des Sciences de l'homme, pp. 45-72.

Cardoso, Ciro (1980a): "Introducción". En: Cardoso, Ciro (ed.): México en el siglo XIX (1821-1910). Historia económica y de la estructura social. México, D.F.: Nueva Imagen, pp. 15-42.

- (1980b): "Las industrias de transformación (1821-1880)". En: Cardoso (1980a), pp. 147-165.

Carmona Badía, Xoán (1984): "Clases sociales, estructuras agrarias e industria rural doméstica en la Galicia del siglo XVIII". En: Revista de Historia Económica, 2, 3, pp. 35-50.

Carneiro, Maria José (1996): "Pluriactivité agricole l'hétérogénéité cachée". En: Cahier d'Économie et Sociologie Rurales, 38, pp. 5-36.

Cayez, Pierre (1981): "Une proto-industrialisation decalée. La ruralisation de la soierie lyonnaise dans la première moitié du XIXe siècle". En: Revue du Nord, 248, pp. 95-103.

Cerman, Markus (1993): "Proto-Industrialization in an Urban Environment. Vienna, 1750-1857". En: Continuity and Change, 8, 2, pp. 281-320.

Ciriacono, Salvatore (1996): "Venise et la Vénétie dans la transition vers l'industrialisation. A propos des thèses de Franklin Mendels". En: Leboutte, René, pp. 291-318.

Coatsworth, John H. (1990): Los orígenes del atraso. Nueve ensayos de historia económica de México en los siglos XVIII y XIX. México, D.F.: Alianza Editorial Mexicana.

Coleman, Donald C. (1983): "Proto-Industrialization. A Concept too Many". En: Economic History Review, 36, 3, pp. 435-448. 
Chao, Kang (1984): "La production textile dans la Chine traditionnelle". En: Annales, Économies-Sociétés-Civilisations, 39, 5, pp. 957-976.

Chassagne, Serge (1991): Le coton et ses patrons. France, 1760-1840. Paris: École des Hautes Études en Sciences Sociales.

Chaudhuri, Kirti N. (1996): "Proto-Industrialization. Structure of Industrial Production in Asia, European Export Trade, and Commodity Production". En: Leboutte, René, pp. 107-128.

Delon, Michel (1999): "En dentelles ou en guenilles". En: Magazine littéraire, 378, pp. 38-39.

Desama, Claude (1981): "Démographie et industrialisation. Le modèle verviétois (1800-1880)". En: Revue du Nord, 63, 248, pp. 147-155.

Dewerpe, Alain (1984): “Genèse proto-industrielle d'une région développée. L'Italie septentrionale". En: Annales, Économies-Sociétés-Civilisations, 39, 5, pp. 896914.

- (1985): L'industrie aux champs. Essai sur la proto-industrialisation en Italie du nord, 1800-1880. Paris: Boccard/Roma: École française de Rome.

Deyon, Pierre (1979): "L'enjeu des discussions autour du concept de 'proto-industrialisation'". En: Revue du Nord, 61, 240, pp. 9-17.

- (1984): "Fécondité et limites du modèle protoindustriel. Premier plan". En: $A n$ nales, Économies-Sociétés-Civilisations, 39, 5, pp. 868-881.

Deyon, Pierre/Mendels, Franklin (1981): "La proto-industrialisation. Théorie et réalité". En: Revue du Nord, 63, 248, pp. 11-16.

Dobb, Maurice (1988): Estudios sobre el desarrollo del capitalismo. México, D.F.: Siglo XXI.

Escobar Latapí, Agustín (1986): Con el sudor de tu frente. Mercado de trabajo y clase obrera en Guadalajara. Guadalajara, Jal.: El Colegio de Jalisco.

Ferrer, Aldo (1963): La economía argentina. Las etapas de su desarrollo y problemas actuales. México, D.F.: Fondo de Cultura Económica.

Frank, André Gunder (1979): Acumulación dependiente y subdesarrollo. México, D.F.: Era.

Furtado, Celso (1979): "El 'desarrollo' desde el punto de vista interdisciplinario". En: El Trimestre Económico, 46, 181, pp. 5-33.

González Enciso, Agustín (1984): "La protoindustrialización en España”. En: Revista de Historia Económica, 2, 1, pp. 11-44.

- (1984a): "La protoindustrialización en Castilla la Vieja en el siglo XVIII". En: Revista de Historia Económica, 2, 3, pp. 51-82.

Goujon, Pierre (1984): "L'industrie en sabots". En: Études Rurales, 93-94, pp. 285291.

Gullickson, Gay L. (1982): "Proto-Industrialization, Demographic Behavior and Sexual Division of Labor in Auffay, France, 1750-1850". En: Peasant Studies, 9 , 2, pp. 106-118.

Gutmann, Myron P. (1996): "War and Industrial Development in Early Modern Europe”. En: Leboutte, René, pp. 153-180. 
Haber, Stephen H. (1992): Industria y subdesarrollo. La industrialización de México, 1890-1940. México, D.F.: Alianza Editorial Mexicana.

- (1999): "Introducción". En: Haber, Stephen (ed.): Cómo se rezagó la América Latina. Ensayos sobre las historias económicas de Brasil y México, 1800-1914. México, D.F.: Fondo de Cultura Económica, pp. 1-46.

Hendrickx, François M. M. (1993): "From Weavers to Workers. Demographic Implications of an Economic Transformation in Twente (The Netherlands) in the Nineteenth Century". En: Continuity and Change, 8, 2, pp. 321-355.

Ho, Samuel P. S. (1984): "Protoindustrialisation, protofabriques et désindustrialisation. Une analyse économique". En: Annales, Économies-Sociétés-Civilisations, 39,5 , pp. 882-895.

Hobsbawm, Eric J. (1977): Histoire économique et sociale de la Grande-Bretagne. De la révolution industrielle à nos jours, vol. 2. Paris: Seuil.

- (1971): Entorno a los orígenes de la Revolución Industrial. México, D.F.: Siglo XXI.

Hoffman, Kai (1982): "Sawmills - Finland's Proto-Industry". En: Scandinavian Economic History Review, 30, 1, pp. 35-43.

Hohenberg, Paul M. (1996): "Urbanization and Proto-Industrialization. Reflections on an Intellectual Journey”. En: Leboutte, René, pp. 9-28.

Hornby, Ove/Oxenbøll, Erik (1982): "Proto-Industrialization before Industrialization? The Danish Case". En: Scandinavian Economic History Review, 30, 1, pp. 3-33.

Hovland, Edgar/Nordvik, Helge W./Tveite, Stein (1982): "Proto-Industrialization in Norway, 1750- 1850. Fact or Fiction?". En: Scandinavian Economic History Review, 30, 1, pp. 45-56.

Hubscher, Roland (1996): De la integración del campesinado en la sociedad global. La pluriactividad, ¿un equilibrio o una desestabilización de la sociedad rural? Mar del Plata: Universidad Nacional de Mar del Plata, Facultad de Humanidades, Departamento de Historia.

Hudson, Pat (1981): "Proto-Industrialization. The Case of the West Riding Wool Textile Industry". En: History Workshop Journal, 12, pp. 34-61.

Hudson, Pat/King, Steve (1996): "A Sense of Place. Industrializing Townships in Eighteenth Century Yorkshire”. En: Leboutte, René, pp. 181-210.

Husbands, Chris (1987): "Regional Change in a Pre-Industrial Economy. Wealth and Population in England in the Sixteenth and Seventeenth Centuries". En: Journal of Historical Geography, 13, 4, pp. 345-359.

Jeannin, Pierre (1980): "La protoindustrialisation. Développement ou impasse? (Note critique)". En: Annales, Économies-Sociétés-Civilisations, 35, 1, pp. 52-65.

Kisch, Herbert (1986): "La industria textil en Silesia y Renania. Un estudio comparativo de sus procesos de industrialización". En: Kriedte et al., pp. 266-298.

Kitching, Gavin (1983): "Proto-Industrialization and Demographic Change. A Thesis and Some Possible African Implications". En: Journal of African History, 24, 2, pp. 221-240.

Kriedte, Peter (1983): Peasants, Landlords and Merchant Capitalist. Europe and the World Economy, 1500-1800. Leamington Spa: Berg. 
Kriedte, Peter, et al. (eds.) (1986): Industrialización antes de la industrialización. Barcelona: Crítica.

- (1993): "Proto-Industrialization Revisited. Demography, Social Structure, and Modern Domestic Industry". En: Continuity and Change, 8, 2, pp. 217-252.

- (1996): "Proto-industrialisation. Bilan et perspectives. Démographie, structure sociale et industrie à domicile moderne". En: Leboutte, René, pp. 29-71.

Landes, David S. (1961): "Encore le problème de la Révolution Industrielle en Angleterre". En: Bulletin de la Société d'Histoire Moderne, 68, 18, pp. 5-7.

- (1975): L'Europe technicienne ou le Prométhée libéré. Révolution technique et libre essor industriel en Europe occidentale de 1750 à nos jours. Paris: Gallimard.

Laslett, Peter (1969): Un monde que nous avons perdu. Famille, communauté et structure sociale dans l'Angleterre pré-industrielle. Paris: Flammarion.

Leboutte, René (1996a): “Adaptation, reconversion, mutations. Le rôle de la protoindustrialisation dans la genèse du bassin industriel liégeois". En: Leboutte, René, pp. 263-290.

- (1996b): "La proto-industrialistion. Recherches récentes - Nouvelles perspectives". En: Leboutte, René, pp. 1-8.

Leboutte, René (ed.) (1996): Proto-industrialisation. Recherches récentes et nouvelles perspectives. Mélanges en souvenir de Franklin Mendels. Genève: Droz.

Levine, David (1996): "Asymmetrical, Non-linear Population Dynamics". En: Leboutte, René, pp. 93-105.

Lewis, Gwynne (1994): "Proto-Industrialization in France". En: Economic History Review, 47, 1, pp. 150-164.

Lindley, Richard B. (1987): Las haciendas y el desarrollo económico. Guadalajara, México, en la época de la independencia. México, D.F.: Fondo de Cultura Económica.

Locke, Robert R. (1981): "French Industrialization. The Roehl Thesis Reconsidered". En: Explorations in Economic History, 18, 4, pp. 415-433.

Mager, Wolfgang (1993): "Proto-Industrialization and Proto-Industry. The Uses and Drawbacks of Two Concepts". En: Continuity and Change, 8, 2, pp. 181-215.

Magnusson, Lars/Isacson, Maths (1982): "Proto-Industrialization in Sweden. Smithcraft in Eskilstna and Southern Dalecarlia". En: Scandinavian Economic History Review, 30, 1, pp. 73-99.

Maitte, Corine (1997): “Incertitudes et bricolages. L'industrie textile à Prato aux 18e et 19e siècle". En: Annales: Histoire, Sciences Sociales, 52, 6, pp. 1275-1303.

Mantoux, Paul (1905): La Révolution Industrielle au XVIIIe siècle. Paris: Société Nouvelle de libraire et de l'édition.

Marx, Karl (1993): Le Capital, vol. 1. Paris: Presse Universitaire de France.

Melton, Edgar (1987): "Proto-Industrialization, Serf Agriculture and Agrarian Social Structure. Two Estates in Nineteenth-Century Russia". En: Past \& Present, 115, pp. 69-106.

Mendels, Franklin (1972): "Proto-Industrialization. The First Phase of the Industrialization Process". En: Journal of Economy History, 32, 1, pp. 241-261. 
- (1981): Industrialization and Population Pressure in Eighteenth-Century Flanders. Reprint of Ph. D. Diss. of 1969. New York: Arno.

- (1984): "Niveau des salaires et âge au mariage en Flandre, XVIIe-XVIIIe siècles". En: Annales, Économies-Sociétés-Civilisations, 39, 5, pp. 939-956.

- (1986): "Agricultura e industria rural en el Flandes del siglo XVIII". En: Kriedte, Peter, et al. pp. 240-265.

Miño Grijalva, Manuel (1989): “Proto-industria colonial?”. En: Historia Mexicana, 38,4 , pp. $793-818$.

- (1993): La protoindustria colonial en Hispanoamérica. México, D.F.: Fondo de Cultura Económica.

O'Brien, Patrick K. (1986): "Do We Have a Typology for the Study of European Industrialization in the XIXth Century?" En: Journal of European Economic History, 15, 2, pp. 291-333.

Ogilvie, Sheilagh C. (1993): "Proto-Industrialization in Europe". En: Continuity and Change, 8, 2, pp. 159-179.

Olveda, Jaime (1991): La oligarquía de Guadalajara. De las reformas borbónicas a la reforma liberal. México, D.F.: Consejo Nacional para la Cultura y las Artes.

Ouweneel, Arij (1989): "The Agrarian Cycle as a Catalyst of Economic Development in $18^{\text {th }}$ Century Central Mexico". En: Ibero-Amerikanisches Archiv, 15, 3, pp. 399-417.

Pacheco, Carlos (1885): Memoria presentada al congreso de la Unión por el secretario del despacho de Fomento, Colonización, Industria y Comercio, correspondiente a los años transcurridos de Diciembre de 1877 a Diciembre de 1882, tomo II. México, D.F.: Oficina Tipográfica de la Secretaría de Fomento.

Pauer, Erich (1991): "The Years Economic Historians Lost. Japan, 1850-1890". En: Japan Forum, 3, 1, pp. 1-9.

Pedreira, Jorge Miguel (1990): "Social Structure and the Persistence of Rural Domestic Industry in $19^{\text {th }}$ Century in Portugal". En: Journal of European Economic History, 19,3 , pp. 521-547.

Peña, Guillermo de la (1986): "Mercado de trabajo y articulación regional. Apuntes sobre el caso de Guadalajara y el occidente mexicano". En: Peña, Guillermo de la/ Escobar, Agustín: Cambio regional, mercado de trabajo y vida obrera en Jalisco. México/Guadalajara, Jal.: El Colegio de Jalisco, pp. 47-88.

Perlin, Frank (1983): "Proto-Industrialization and Pre-Colonial South Asia". En: Past \& Present, 98, pp. 30-95.

Pfister, Ulrich (1996): “A General Model of Proto-Industrial Growth". En: Leboutte, René, pp. 73-92.

Poni, Carlo (1982): "Protoindustrializazione. Un commento". En: Quaderni Storici, 17,3, pp. 1103-1111.

Rabellotti, Roberta (1997): External Economies and Cooperation in Industrial Districts. A Comparison of Italy and Mexico. Basingstoke, Hampshire/London: Macmillan.

Riojas López, Carlos (1999a): Industria y estrategia económica en México, 18771992. El caso de Jalisco. Guadalajara, Jal.: Universidad de Guadalajara. 
- (1999b): L'industrialisation au Mexique pendant le XIXe siècle. Le cas du Jalisco. Tesis doctoral. Paris: École des Hautes Études en Sciences Sociales.

- (2000): "Desafíos para el estudio de la dinámica demográfica en Jalisco durante el siglo XIX". En: Papeles de población, 6, 26, pp. 221-247.

- (2003): Las intransitables vías del desarrollo. El proceso de industrialización en Jalisco durante el siglo XIX. Guadalajara, Jal.: Universidad de Guadalajara.

Rostow, Walt W. (1962): Les étapes de la croissance économique - un manifeste non communiste. Paris: Seuil.

Rudolph, Richard L. (1985): "Agricultural Structure and Proto-Industrialization in Russia. Economic Development with Unfree Labor". En: Journal of Economic History, 45, 1, pp. 47-69.

Sabel, Charles/Zeitlin, Jonathan (1985): "Historical Alternatives to Mass Production. Politics, Markets and Technology in Nineteenth-Century Industrialization". En: Past \& Present, 108, pp. 133-176.

Saito, Osamu (1996): "Gender, Workload and Agricultural Progress. Japan's Historical Experience in Perspective". En: Leboutte, René, pp. 129-151.

Salvucci, Richard J. (1992): Textiles y capitalismo en México. Una historia económica de los obrajes, 1539-1840. México, D.F.: Alianza Editorial Mexicana.

Schön, Lennart (1982): "Proto-Industrialisation and Factories. Textiles in Sweden in the Mid-19 ${ }^{\text {th }}$ Century". En: Scandinavian Economic History Review, 30, 1, pp. 57-72.

Serrera, Ramón María (1991): Guadalajara ganadera. Estudio regional novohispano, 1760-1805. Guadalajara, Jal.: Ayuntamiento de Guadalajara.

Sunkel, Osvaldo (1971): El subdesarrollo latinoamericano y la teoria del desarrollo. México, D.F.: Siglo XXI.

Sweezy, Paul M., et al. (1964): La Transición del Feudalismo al Capitalismo. Medellín: THF.

Thomson, Guy P. C. (1989a): "Traditional and Modern manufacturing in Mexico, 1821-1850". En: Liehr, Reinhard (ed.): América Latina en la época de Simón Bolívar. La formación de las economías nacionales y los intereses económicos europeos 1800-1850. Berlin: Colloquium, pp. 55-85.

- (1989b): Puebla de los Ángeles. Industry and Society in a Mexican City, 17001850. Boulder, Col.: Westview Press.

- (1991): "Continuity and Change in Mexican Manufacturing, 1800-1870". En: Batou, Jean (ed.): Between Development and Underdevelopment. The Precocious Attempts at Industrialization of the Periphery, 1800-1870. Genève: Droz.

Torras Elías, Jaime (1984): "Especialización agrícola e industria rural en Cataluña en el siglo XVIII". En: Revista de Historia Económica, 2, 3, pp. 113-127.

Van der Wee, Herman/D'Haeseleer, Peter (1996): "Proto-Industrialization in SouthEastern Flanders. The Mendels Hypothesis and the Rural Linen Industry in the 'Land van Aalst' during the 18th and 19th Centuries". En: Leboutte, René, pp. 243262.

Van Young, Eric (1989): La ciudad y el campo en el México del siglo XVIII. La economía rural de la región de Guadalajara, 1675-1820. México, D.F.: Fondo de Cultura Económica. 
Vandenbroeke, Christian (1984): "Le cas Flamand. Évolution sociale et comportements démographiques aux XVIIe-XVIIIe siècles". En: Annales, Économies-Sociétés-Civilisations, 39, 5, pp. 915-938.

- (1996): "Le problème de la durée du travail aux Temps Modernes". En: Leboutte, René, pp. 237-242.

Vries, Jan de (1994): "The Industrial Revolution and the Industrious Revolution". En: Journal of Economic History, 54, 2, pp. 249-270.

Weber, Max (1991): Histoire économique. Esquisse d'une histoire universelle de l'économie et de la société. Paris: Gallimard.

White, James W. (1989): "Economic Development and Sociopolitical Unrest in Nineteenth-Century Japan". En: Economic Development and Cultural Change, 37, 2, pp. 231-260.

Zeitlin, Jonathan (1985): "Les voies multiples de l'industrialisation". En: Mouvement Social, 133, pp. 25-33. 


\section{Lucía Martínez Moctezuma}

\section{Íñigo Noriega Laso: un empresario agrícola en México 1868-1913}

Nuestro estudio aborda la trayectoria de un inmigrante español. Se trata de un personaje que, al igual que otros miembros de la colonia española en México, construirá su fortuna en un tiempo muy corto y pertenecerá a esta inmigración privilegiada que conoció el éxito, aunque efímero. Sus alianzas políticas durante el periodo revolucionario lo colocarán del lado equivocado y su fortuna se le escapará más rápido de lo que le había tomado construirla.

Describir la actividad empresarial de un inmigrante asturiano como Íñigo Noriega Laso, a través de su comportamiento, nos permite señalar la influencia de los individuos en la conducta de la innovación. ${ }^{1}$ Nuestro inmigrante no debe ser considerado como un caso especial, pero sí como un ejemplo representativo de una población de empresarios exitosos, revelador de una sociedad, ${ }^{2}$ que igual establece diversas estrategias de inversión y de multiplicación de capital, consolida una sólida red de relaciones útiles a sus fines y mantiene rasgos tradicionales como la mentalidad señorial y el prestigio social.

Este trabajo se dirige en dos direcciones. La primera concierne a la trayectoria comercial del empresario. Siguiendo una línea de análisis descriptiva, nos proponemos enumerar sus actividades, junto con su hermano Remigio, desde su llegada a México en 1868: el comercio, la explotación de tabaco y la industria textil. La segunda dirección se inicia en 1898 cuando Íñigo Noriega, ya con una fortuna considerable, inicia un periodo decisivo en su vida empresarial, a través de la cual podremos seguir su mentalidad de empresario moderno: la diversifica-

1 "Los comerciantes y vendedores, descritos de esta manera y analizados en su actividad económica, obtienen su significación no como figuras singulares, sino como ejemplificación de mecanismos que son conducidos por individuos" (Bernecker 1992: 164).

2 Según J. B. Say, el espíritu de empresa es un comportamiento y no un rasgo de carácter, además, el empresario busca el cambio, una obra de "destrucción creativa" (Drucker 1985: 51-53); véase también Piqueras (1994: 54-62). 
ción de sus inversiones, sobre todo, en la agricultura junto a un importante grupo de socios y amigos.

\section{De España a México: itinerario}

A lo largo del siglo XIX y durante el primer tercio del XX, gran número de europeos abandonaron sus terruños para buscar otros horizontes, hallando nuevos lugares de trabajo y de asentamiento en otros continentes, especialmente en América.

Durante este periodo en España hubo un constante movimiento migratorio, más intenso hacia mediados del siglo XIX, cuando se suprimieron los obstáculos legales y se agudizó la crisis económica causada por el atraso de las regiones caracterizadas por el caciquismo, la usura y el arrendamiento a pequeña escala. ${ }^{3}$

Aunque las tendencias y los tiempos de la emigración variaron regionalmente, puede decirse que entre 1880 y 1930 llegaron a América casi 300.000 asturianos. De ellos casi un 50\% se instaló en Cuba, Argentina y como tercera opción desembarcaron no sólo en la ciudad sino en diferentes regiones de México. Importantes familias como los Basagoiti, Ibáñez, Romano, Gavito y Noriega hicieron fortunas enor$\mathrm{mes}^{4}$ como terratenientes, comerciantes y empresarios industriales de la época. En la ciudad y el estado de México, en Michoacán, Puebla y Yucatán su presencia fue remarcable, no sólo a nivel de la explotación y modernización de la industria textil, sino también en el aspecto crediticio. $^{5}$

3 Cristobal Botella, en 1888, definía el fenómeno migratorio como un acto por el cual el individuo abandona su patria con idea o no de regresar para establecerse en otro país. Inherentes a su naturaleza eran el cambio de residencia o abandono de la patria y la voluntariedad en el desplazamiento (Pérez-Prendes y Muñoz de Arraco 1993: 22).

4 Sánchez-Albornoz (1988: 21) y Sánchez-Albornoz/Llordén (2003: 7-13). En la última década del siglo XIX se redujo la tradicional salida asturiana a la Gran Antilla como consecuencia de las revueltas y la guerra de independencia cubana, cambiando el destino hacia México (véase Ojeda/San Miguel 1985: 26).

5 Véase como ejemplo los trabajos de Mörner (1992); González Loscertales (1983); Síndico et al. (1985); Cerutti (1995); Cerutti/Barragán (1993); Liehr (1996); Bermejo Lorenzo (1998); Herrero (1999a; 1999b; 2000; 2002); Tortolero (2001); Martínez Moctezuma (2001); Pérez de Sarmiento/Savarino Roggero (2001); Uribe Salas (2003). 
El modelo del proceso migratorio seguía siendo, a fines del siglo XIX, el que Lucas Alamán describía para el siglo anterior: considerar al inmigrante español como aquel que llegaba a México y tenía como objetivo trabajar arduamente y hacer una fortuna. Aquellos que llegaban sin un empleo fijo dejaban su patria muy jóvenes y pertenecían casi siempre a familias con limitados recursos. Otros llegaban a servir directamente en casa de algún pariente o amigo de la familia. La mayoría comenzaba como dependientes sujetos a una verdadera disciplina, lo que les hacía considerar el trabajo como el único camino a la riqueza. ${ }^{6}$

Además de encontrar trabajo, en muchas ocasiones los inmigrantes españoles se relacionaban con la burguesía mexicana a través de matrimonios, estableciendo importantes relaciones y vínculos que les servirían a lo largo de su carrera empresarial. La opinión de Telésforo García es elocuente:

[...] sólo pueden venir a México. Aquí es donde han venido siempre, y aquí es donde seguirán viniendo. México es el único punto del globo donde encuentran esposa, que nunca traen de España, trabajo y fortuna. En México es únicamente donde los aventureros se tornan laboriosos; los insignificantes y desheredados en padres de familia responsables [...].

De estos emigrantes los más afortunados lograban disponer de un capital inicial -normalmente prestado por algún próspero comerciante, miembro de la colonia española- que les permitía establecerse por su cuenta. Aunque muchos provenían del medio rural, pocos se integraron a ese universo y prefirieron los núcleos urbanos. Con una visión precisa del trabajo, una buena dosis de suerte, pero sobre todo con vínculos como la amistad, el parentesco, el compadrazgo, etc., acumulaban un cuantioso capital iniciado en el comercio, en las fábricas

6 Para las impresiones de Alamán, véase Bojórquez (1932: 4-5).

7 El caso de Telésforo García es típico del grupo español. El contraer matrimonio con Luz Castañeda y Nájera, hija de una importante familia mexicana, le permite establecer una red de relaciones que lo llevan a desempeñar toda una gama de actividades: periodista, comerciante, empresario exitoso y audaz, director y propietario de los periódicos La Libertad y El Centinela Español. Considerado "[...] íntimo de todos los hombres públicos de España por no decir consejero; dueño y superhombre de la colonia, el de los brindis obligado [...] de una fatuidad que crece con los años y víctima por desgracia de la vanidad de familia; el representante genuino in potentis de España en México". Véase Hale (1991) y Archivo del Ministerio de Asuntos Exteriores, Madrid (AMAEM), Informe de B. Cólogan, leg. 2558, núm. 96, México, 13 de abril de 1914, f. 4. 
textiles y en la producción de tabaco. De no contar con estos elementos, su vida transcurría como empleados por cuenta ajena, en el comercio, en las fábricas o en la agricultura, como administradores, capataces o mayordomos. ${ }^{8}$

Nuestro personaje pertenece a una familia de hidalgos ${ }^{9}$, de hombres políticos y de pequeños propietarios, para quienes la experiencia de emigrar representaba una esperanza de mejorar su situación material más que una necesidad ligada a la pobreza absoluta. ${ }^{10}$

Noriega mismo lo señala al solicitar una cédula de vecindad para su embarque:

[...] tengo proyectado trasladarme a la República de Méjico con el objeto de beneficiar mi fortuna dedicándome al comercio ó a otra profesión honrosa $[\ldots]$ tengo licencia de mis padres $[\ldots]$ no trato de eludir ningún compromiso $[\ldots]$ (ni) huir del servicio de las armas [...] y no adolezco de nota fea ni tengo impedimento racional para mi embarque $[\ldots] .{ }^{11}$

Es su tío, Íñigo Noriega Mendoza, establecido en México desde 1860, quien va a invitar a los hermanos Noriega -Íñigo y Remigio- a venir a México para ocuparse de sus negocios, siguiendo el tradicional viaje "en cadena", como ha señalado Clara Lida. Esta idea confirma que no todos los empresarios del Porfiriato llegaron con las manos vacías a "hacer las Américas"; así pues, en un tiempo muy corto, los Noriega acrecentaron su fortuna considerablemente.

En perspectiva, sabemos que los grandes momentos de Íñigo Noriega comienzan con su llegada en 1868 a la ciudad de México, donde va a trabajar en el negocio familiar, una vinatería, tienda de ultramarinos y fábrica de cigarros llamada "La Mariscala", ${ }^{12}$ después en el co-

8 González Loscertales, Vicente (1979: 273) y Álvarez Quintana (1986: 260-261).

9 "La gran extensión de la hidalguía explica la existencia de hidalgos pobres, incluso los considerados viles, para el escándalo de los defensores del prestigio nobiliario" (Pérez Vejo 1984: 21). Agradezco a Tomás Pérez Vejo el haberme facilitado una copia de esta mítica publicación.

10 En el Archivo Histórico del Ayuntamiento de Colombres, Asturias, puede seguirse el apellido Noriega para localizar los registros de riqueza y de los cargos concejiles de la familia. Véanse Padrones de Riqueza del Concejo de Ribadedeba, Años 1865-76, Carpetas 23, 27 y 127. Además: Registro de Hacendados de 1840, Carpeta 11.

11 Archivo Privado de la Familia Solano Martino (APFSM).

12 Con apenas la enseñanza primaria recibida en Cobreces, Íñigo comenzó desde abajo, cumpliendo las tareas más duras como casi todos los españoles que llegaban a México para trabajar en los negocios familiares. Los recuerdos de su hija 
mercio del mexicano Vicente de Paúl Castro, en el Barrio de Jamai$\mathrm{ca},{ }^{13}$ hasta que en 1873 , su hermano Remigio abre su propio negocio llamado "El Borrego". Remigio se declaraba importador y responsable de la casa comercial e Íñigo fungía como su apoderado.

En 1886, los hermanos Noriega van a constituir la Sociedad Comercial Remigio Noriega y Hermano con la cual acumularán una fortuna de alrededor de 7 millones de pesos, invertida en el comercio, en la explotación de tabaco y más tarde en otros dominios. ${ }^{14}$

Después de doce años, esta sociedad se finiquitó. Íñigo Noriega va a conservar la mayor parte de la fortuna familiar en sus manos. Su comportamiento como empresario durante el periodo de 1898 a 1913 lo conducirá a invertir casi el $90 \%$ de su capital en la explotación agrícola del norte del país y del valle de México, el resto lo invertirá en bienes raíces (7\%) y en la industria textil (3\%). Su fortuna en 1904 era de casi 16 millones de pesos y, después de 1913, será tres veces más importante. $^{15}$

Las estrategias que empleó Noriega para obtener beneficios fueron las relaciones, el matrimonio, la creación de sociedades anónimas y el control de éstas, así como su espíritu emprendedor y otras que comentaremos a continuación.

Íñigo Noriega Laso fue un hombre de negocios moderno que estableció una intensa red de relaciones con otros empresarios y personajes políticos de la época. En la cima de esta pirámide se encontraba el

Gloria ilustran este hecho: "[...] pensaba que sería de los predilectos, ya que mantenía lazos sanguíneos con el dueño...su sorpresa fue grande cuando se vio en la necesidad de dormir sobre el mostrador de la tienda, escenario pequeño para la mentalidad de sus vuelos [...]". Entrevista a Gloria Noriega Rivero, en Noriega Gayol (1992: 2).

13 AHTSJ, Juzgado 11 del Ramo Civil, exp. 64426.

14 Su fortuna estaba invertida de la siguiente manera: 4.302 .500 pesos en la explotación agrícola; 1.000 .000 pesos en la industria textil; 923.267 pesos en los bienes raíces; 637.000 pesos en la industria minera; 458.657 pesos en la especulación de créditos y 48.652 pesos en la producción y comercio del tabaco (Martínez Moctezuma 2001).

15 Entre 1898 y 1913, Íñigo Noriega reinvirtió este capital sobre todo en la explotación agrícola del norte y del centro del país. En un lapso de 15 años va a sextuplicar su fortuna, aumentándola a casi 50 millones de pesos. Además de nuestras estimaciones, un documento posterior a 1910 lo señala: "[...] no es ninguna exageración al asegurar que el Sr. Noriega, antes de la Revolución en México, era poseedor de un capital de unos cuarenta millones de pesos [...]", APFSM, sin referencia más detallada. 
presidente Díaz, quien era su albacea testamentario, los gobernadores Zubieta y Villada en el estado de México, así como sus socios, Porfirio Díaz hijo, Thomas Braniff, José de la Macorra, Antonio Basagoiti, Augusto Genin y otros.

El "buen matrimonio" también fue una de las estrategias que utilizó Noriega para extender su fortuna y sus relaciones. ${ }^{16}$ En 1876 contrajo matrimonio con Guadalupe Castro García, hija de su patrón, el comerciante mexicano Vicente de Paúl Castro, quien le facilitó establecer contactos con los comerciantes mexicanos de la época. Subrayemos el hecho de que sus oficinas comerciales se encontraban ubicadas en la misma calle, y en diferentes ocasiones no sólo su reputación de empresario mexicano sino el monto de sus bienes lo respaldó, cuando en los tribunales íñigo Noriega se veía obligado a responder por el secuestro de los bienes de sus adversarios. Sus nueve hijas se vincularon también a la élite porfirista a través de matrimonios con las familias Martino, Sordo Pedregal, Armendáiz y Rodríguez.

En este ambiente ideal Íñigo Noriega supo establecer diversas estrategias participando en la creación de múltiples sociedades anónimas; gracias a su sentido innovador reunió todas sus propiedades en empresas agrícolas como La Sauteña, Xico, la Compañía Agrícola y Colonizadora Mexicana, así como también la Compañía Textil de San Antonio Abad.

En estas sociedades anónimas Noriega aumentó su capital, controló todos los factores de producción, eliminó a sus competidores y además tuvo la habilidad de colocarse como gerente general a la cabeza de los consejos de administración, lo que le facilitó imponer sus opiniones.

El control de los factores de producción le permitió tener el poder sobre el transporte, el aprovechamiento de los recursos naturales, las materias primas y los mercados, con esta política era evidente que los conflictos sociales estallaban a causa de sus abusos y la sociedad comercial se veía obligada a manipular al aparato de Estado con el propósito de dar continuidad a sus proyectos.

16 John Kicza (1986) en su estudio sobre la élite de fines de la época colonial en México introduce una serie de variables útiles para caracterizar a este grupo y sus matrimonios. La obediencia a éstas -la estrategia matrimonial- acorde con los deseos económicos y sociales permitía por mucho tiempo su permanencia en la cima de la jerarquía social. 
En el caso de las compañías agrícolas -La Sauteña y Xico- pudo realizar grandes proyectos, como la compra de terrenos que tenían como objetivo aumentar la superficie, además de modernizarlas con maquinaria nueva y con ello se ligó al capital extranjero a través de préstamos.

Otra estrategia de Íñigo Noriega como empresario moderno fue la de conservar su calidad de extranjero. Este hecho le permitió obtener una serie de ventajas, como establecer lazos económicos con el exterior y en periodos de crisis, solicitar la protección de su Gobierno con el fin de asegurar sus propiedades, su seguridad personal, solicitar indemnizaciones, etc.

Su vínculo con el extranjero le permitió también conocer el desarrollo tecnológico, los métodos de producción, aprovechar la venta de máquinas y contratar al personal especializado necesario en la realización de sus proyectos. La aplicación de nuevos métodos de producción en el dominio textil, minero y agrícola, lo llevaron a acercarse a un universo más largo de inventores, de técnicos, de ingenieros, etc. ${ }^{17}$ Lo vemos, por ejemplo, en las sociedades que buscaban distribuir nuevas máquinas textiles inventadas por los hermanos Prieto y construidas en España (Sociedad Romano, Noriega y Prieto); o en el mejoramiento de una fórmula de extracción de mineral (Sociedad de Beneficio Eléctrico Nacional) y una nueva manera de extraer la resina sin agotar los árboles con la dirección del horticultor zaragozano Mariano Gajón.

Sin embargo, este proyecto modernizador se enfrentó a múltiples obstáculos, como el movimiento campesino de 1910 y la disputa entre las élites. En esta situación, Íñigo Noriega encarna una paradoja de la modernidad: un empresario innovador que sostiene las fuerzas políticas del antiguo régimen. Esta estrategia tan útil durante el Porfiriato, no lo será más en 1913, cuando el poder del villismo y del zapatismo aumenta.

17 Este comportamiento lo encontramos también en el caso francés "[...] l'une des préoccupations constantes du chef d'entreprise dynamique est suivre l'innovation partout où elle éclôt, et pour cela en être informé 'de premier main' avant ses concurrents [...] le travail patronal tient dans une obligation d'information [...]" (Chassagne 1980: 230). 


\section{La dinámica empresarial de Íñigo Noriega}

Al separase comercialmente de su hermano Remigio, Íñigo continuó explotando los negocios familiares orientados a la industria textil, de bienes raíces y sobre todo agrícolas, donde puso gran interés en la explotación de sus negociaciones agrícolas del centro y norte del país. ${ }^{18}$

\subsection{La industria textil}

En enero de 1892 los hermanos Noriega crearon una sociedad anónima Ilamada Compañía Industrial de Hilados, Tejidos y Estampados de San Antonio Abad, que tenía como objetivo la producción de textiles, la compra y venta de algodón y la adquisición de otras fábricas o su arrendamiento. ${ }^{19}$

Se trataba de una fábrica alimentada por seis calderas que hacían trabajar 40 cardas para el algodón, 350 telares y 12.200 husos traídos de Inglaterra y Alemania. Su producción en 1897 era de alrededor de 500.000 kilogramos de hilo, 240.000 piezas de manta y 400.000 piezas de percal estampado por medio de cilindros de cobre, por lo que un viajero de la época la ubicaba "en lugar primero en el Distrito Federal". El progreso que había logrado Noriega en poco tiempo, cuando era exclusivamente de su propiedad, llamaba la atención del visitante, pero también el hecho de que la fábrica estuviera ahora en manos de una sociedad anónima que no había perfeccionado la producción de los artículos. Por ello, recomendaba a sus nuevos administradores que se preocuparan por desarrollar el aspecto de los conocimientos técnicos, con el fin de mejorar la producción para poder competir con los productos extranjeros (Figueroa Doménech 1899: 187-188).

De esta manera, Noriega a la cabeza del consejo de administración implementó dos estrategias para aprovechar al máximo estas ideas: establecer sucursales en el extranjero donde se construyeran máquinas mejor fabricadas y solicitar los servicios de personal calificado.

Para ello, el empresario asturiano participó en la creación de la sociedad "Romano, Noriega y Prieto", que tenía sucursales en Barcelona, y cuyo fin era construir, vender y explotar máquinas para desfibrar

\footnotetext{
18 El destino empresarial de Remigio Noriega puede seguirse en Martínez Moctezuma (2001: 33-40).

19 ANCM, notario José Villela, acta 31, México, 28 de enero de 1892, f. 57.
} 
máquinas textiles. Pero la preocupación de la compañía por ser la mejor en su ramo no se limitaba únicamente a buscar el mejoramiento de la maquinaria, sino también el de sus fórmulas de fabricación, por consiguiente, la compañía registró en los mercados internacionales su marca industrial llamada: le meilleur noir $d u$ monde, empleada en la fabricación de percales de calidad ${ }^{20}$ y contrató los servicios del ingeniero Eloy Noriega ${ }^{21}$ y del ingeniero mecánico Francisco P. Pujadas, residente en España, para mejorar las máquinas que se fueran construyendo. $^{22}$

Sus proyectos se desarrollaban con éxito y, por ello, no resulta extraño que se propusiera crecer en el ramo. En marzo de 1898 compra la fábrica de Miraflores en el distrito de Chalco a la sociedad en comandita J. H. Robertson y Cía. Con ésta y otras compras en la región formó la Compañía Industrial de Hilados, Tejidos y Estampados San Antonio Abad y sus anexas: La Colmena, Barrón y Miraflores, S.A. ${ }^{23}$

Para asegurar su buen funcionamiento, Noriega también se preocupó de abastecerlas de leña. En 1894 se comprometió por diez años para hacer las entregas por ferrocarril o hasta la Garita de La Viga, si el transporte era por el canal, de las cantidades necesarias. ${ }^{24}$

La madera provenía de los bosques que rodeaban sus haciendas del estado de México. Es interesante ver que hacia esta época los Noriega centran su atención en esta zona boscosa, lo que les permitirá llevar a cabo proyectos como éste, de abastecimiento, además de los de transporte, con la introducción del ferrocarril en la zona.

Como hemos visto, esta experiencia fue importante para los Noriega, pues les permitió compartir un proyecto a diferentes niveles construcción de maquinaria, mejoramiento técnico de la fórmula de

20 ANF, F 12, 7150, janvier 1893.

21 Su currículum resulta impresionante: de 32 años y con 20 diplomas de honor, seis grandes premios y 56 medallas de oro en diversas exposiciones de Europa y América. Miembro de la Academia de Ciencias y del Instituto Científico de Bruselas y de la Academia de Inventores de París, era originario de Colombres y titulado por la Universidad de Bruselas (Figueroa Doménech 1899: 67).

22 ANCM, notario José Villela, acta 213, México, 21 de junio 1893, f. 196.

23 ANCM, notario Juan M. Villela, acta 97, México, 30 de marzo 1898, fs. 171-174 y acta 19, México, 15 de julio 1899, f. 47.

24 El precio acordado fue de 14 pesos el zontle de cuatrocientas rajas, que pesaban alrededor de 130 arrobas, acordando su pago por peso y no por pieza. El pago se haría semanalmente, cada sábado. ANCM, notario José Villela, acta 118, México, 13 de octubre 1894, f. 168. 
fabricación, compra de otras fábricas, abastecimiento de leña- en común con otros empresarios, cuyos objetivos eran ambiciosos, pues además de la fabricación y comercio de hilados y tejidos buscaban construir y explotar ferrocarriles, telégrafos, teléfonos, acueductos y accesorios para obtener fuerza motriz, celebrar contratos con el Gobierno y cooperar con otras compañías. ${ }^{25}$ Su capital social era de dos millones de pesos.

\subsection{La explotación agrícola}

Una de las estrategias de Noriega para hacer producir su capital en este dominio fue la formación de compañías agrícolas. Nuestro empresario reinvertirá su capital en la formación de la Compañía Agrícola de Xico y Anexas S.A., la Compañía Agrícola y Colonizadora Mexicana S.A., en el estado de México, y en La Sauteña, en el norte del país.

En el valle de México, sus propiedades se ubicaban en la fértil región de Chalco. Allí, desde la época colonial, la hacienda cerealera había alcanzado su forma más desarrollada, debido a la existencia de tierras fértiles, favorables condiciones climáticas, vías fluviales de comunicación y la cercanía con la ciudad de México (Gibson 1967). En esta zona existían, en la última década del siglo pasado, treinta haciendas que ocupaban las tierras más ricas y una vasta zona de alrededor del 73\% de la superficie total del distrito (García Luna 1981).

Hacia 1889, once de estas haciendas pertenecían a cinco españoles y para 1910, cinco de éstas son de Íñigo Noriega. Esta proporción aumenta si consideramos que sus haciendas eran de las más ricas y más productivas en el distrito. Su presencia será decisiva en la economía de la región. Entre 1886 y 1905 comprará las haciendas de Zoquiapan, La Compañía, Río Frío, Ixtlahuacán, San Juan de Dios y los Ranchos de Xico, de Córdoba y de San Isidro. Todas éstas ubicadas entre lagos y volcanes.

El caso de Noriega no era aislado, correspondía a una lógica que era propia de la época y que nuestro empresario supo aprovechar al máximo. A nivel nacional muchos de los hacendados de la región eran miembros de la Sociedad Agrícola Mexicana, el lugar ideal para establecer relaciones, comunicar sus innovaciones, estar al tanto de la

25 ANCM, notario Juan M. Villela, acta 5, México, 5 de enero 1899, fs. 13-17. 
maquinaria más moderna y discutir sus problemas con el fin de maximizar sus resultados. A nivel regional las condiciones eran propicias para emprender grandes proyectos con el apoyo decidido del gobernador Villada.

\subsubsection{La Compañía Agrícola de Xico y Anexas S.A.}

En 1897, la Sociedad Remigio Noriega y Hermano invita a reconocidos empresarios de la época para constituir por 99 años la Compañía Agrícola de Xico y Anexas, Sociedad Anónima. Entre los inversionistas se encontraban comerciantes españoles, mexicanos y franceses, corredores austríacos, banqueros ingleses e industriales norteamericanos. ${ }^{26}$

La sociedad tenía dos objetivos: la explotación agrícola e industrial de las fincas rústicas denominadas Xico y La Compañía y la explotación de la concesión presidencial que les había sido otorgada desde abril de 1895, cuyo objeto era conducir por medio de un canal las aguas depositadas en el lago de Chalco, haciendo a la vez el drenaje y la desecación de los terrenos para usos agrícolas e industriales. ${ }^{27}$

Gracias a un avalúo, realizado por corredores de la época, conocemos el trabajo que los Noriega habían dedicado a ella.

La Hacienda de La Compañía es muy conocida y está generalmente considerada como una de las primeras ó como la primera en el Distrito [...] los rendimientos que anteriormente daba producían un interés conveniente del capital empleado en la propiedad y en su explotación. Después de haberla adquirido los Señores Remigio Noriega y Hermano la han mejorado notablemente con aumento de terrenos y obras de importancia que han subido sensiblemente sus productos anuales [...] (Ibid., anexo).

La extensión total de la Compañía Agrícola de Xico era de aproximadamente 14.500 hectáreas, de las cuales 9.000 eran de siembra y el resto de monte. Sus haciendas producían entre 120.000 y 150.000 cargas de maíz al año, que representaban una ganancia de casi 1.500 .000

26 Entre los accionistas se encontraban Thomas Braniff, José Sánchez Ramos, Faustino Martínez, Luis Barroso, Antonio Basagoiti y otros. Hacia 1905 otros nombres se agregaron a éstos: Roberto Gayol, Enrique Torres Torrija y otros, ANCM, notario Juan M. Villela, acta 1, México, 11 de julio 1897, fs. 1-7 y acta 2001, México, 21 de noviembre 1905, fs. 98-103.

27 El enfrentamiento de los proyectos empresariales de Noriega con los pueblos aledaños puede seguirse en Tortolero (2001: 25-34). 
pesos. ${ }^{28}$ En los terrenos de esta compañía también se sembraba trigo, cebada, frijol, haba y toda clase de hortalizas.

En la hacienda de La Compañía se plantaron también cerca de 150.000 variedades de árboles frutales. Además, había 1.000 cabezas de vacunos lecheros importadas de Holanda y Suiza, que producían 10.000 litros de leche diarios y, una cría de caballos andaluces e ingleses de raza fina que le habían hecho ganar al asturiano un segundo premio en la Exposición de ganado de Coyoacán (El Correo Español 1904). También funcionaba una ladrillera moderna, que fabricó por mucho tiempo los tabiques y ladrillos con los que se urbanizaron los terrenos de San Antonio Abad y La Viga de la Compañía Agrícola y Colonizadora Mexicana S.A. ${ }^{29}$

Se trataba de una propiedad moderna, que hacia 1897 tenía tres trilladoras, tres segadoras, seis sembradoras, dos desgranadoras, 26 cultivadoras y más de 100 arados. Con estas apreciaciones su valor quedaba claramente establecido. Las fincas, sus anexos y la concesión que se aportaba estaba valuada en dos millones y medio de pesos más 500.000 pesos, que aportaban el resto de los accionistas. ${ }^{30}$ Sus proyectos de modernización de las vías de comunicación serán retomadas en la Compañía Agrícola y Colonizadora Mexicana S.A.

En lo que respecta a la empresa agrícola de Xico, se nota lo que algunos autores han catalogado como una verdadera revolución agraria en la región de los volcanes (Tortolero 2000). En efecto, sí las ca-

28 APFSM, sin referencia y Morales Saro/Llordén Miñambres (1992: 56-57).

29 Todas las labores se realizaban con éxito, por lo que no resulta extraño conocer la opinión de los corredores: "[...] de escaso o ningún valor cuando sus tierras estaban cubiertas por las aguas del Lago, es ahora una de las fincas más importantes de las cercanías [...] merced a las obras de desecación ejecutadas con gran éxito [...]. No podíamos emitir opinión más fundada que la de todos los Ingenieros que han estudiado el desagüe del Valle y todos los capitalistas que han estudiado el aprovechamiento de las tierras desecadas y que unánimes han considerado las obras de desecación como en extremo valiosas e importantes y como un excelente negocio la explotación de las tierras antes ocupadas por las aguas [...]", ANCM, notario Juan M. Villela, acta 2001, México, 21 noviembre 1905, anexo, fs. VI-VII.

30 El número de acciones para cada miembro eran las siguientes: 25.000 para la Sociedad Remigio Noriega y Hermano; 500 para Thomas Braniff, José Sánchez Ramos, Henry C. Waters, Luis Barroso, Faustino Martínez, A. Richaud y Compañía y Antonio Basagoiti; 300 para Solana, Barreneche y Compañía; 250 para Prudenciano Dorantes; 200 para Manuel Romano Gavito, Alberto Hackmack, José Breier y Valentín Elcoro y 150 para Noriega y Compañía. 
racterísticas principales de la revolución agraria en Europa son tres: los cambios en los métodos de cultivo, las transformaciones en los sistemas de propiedad y el espíritu empresarial de los agricultores. Entonces, estas tres características las encontramos en Noriega, quien introduce maquinaria y nuevos cultivos en sus empresas en una escala impresionante, transforma el paisaje agrario con la desecación del lago y cambia las relaciones de propiedad con los pueblos y, finalmente, el espíritu de empresa del asturiano lo lleva a producir cantidades de maíz y productos destinados al mercado de la ciudad de México, que diversos autores como Genin subrayan con admiración.

\subsubsection{La Compañía Agrícola y Colonizadora Mexicana S.A.}

Esta compañía fue constituida el 6 de junio de 1911. Tenía como objetivo la adquisición, fraccionamiento, venta de terrenos urbanos, la explotación de sus propiedades agrícolas, así como la terminación de la vía del ferrocarril de México a Río Frío. ${ }^{31}$

Eran propiedad de esta compañía las haciendas de Zoquiapan, Venta Nueva, Río Frío, Venta de Córdoba, el ferrocarril de Río Frío, varias casas y un millón $600 \mathrm{mil}$ metros cuadrados de terreno entre la calzada de Tlalpan y La Viga en la ciudad de México.

Las haciendas de Zoquiapan y Venta Nueva producían cebada, maíz y alrededor de 2.000 cubos diarios de pulque, igual a una ganancia de 365.000 pesos anuales. La Venta de Córdoba y Río Frío producían cientos de furgones cargados de raíz de zacatón y trementina que eran transportados por el ferrocarril de Río Frío. ${ }^{32}$

Los terrenos en la ciudad de México serían urbanizados con el fin de crear una colonia de obreros. Todos estos proyectos eran respaldados con el capital de un grupo de accionistas y un préstamo de casi

31 Los accionistas que participaban eran: Pío Noriega, quien fungía como presidente del consejo de administración, José Zubieta, el ingeniero Roberto Gayol, Florencio González, Íñigo García Borbolla, Antonio de Paúl Moreno, Emilio Pimentel, secretario de la misma, e Íñigo Noriega, quien aportaba la mayor parte de sus propiedades en la ciudad y el estado de México. AGN, Caja de Préstamos, exp. 280 y ANCM, notario Juan M. Villela, acta 5596, México, 17 de octubre 1911.

32 APFSM, sin referencia. Memorándum para el secretario de Hacienda y Crédito Público, don Luis Montes de Oca sobre algunos negocios de don Íñigo Noriega. 
cinco millones de pesos que había hecho la Caja de Préstamos para Obras de Irrigación y Fomento de la Agricultura.

Como podemos ver, en esta compañía agrícola nuestro empresario llevará a cabo tres proyectos modernizadores: la urbanización de terrenos en la ciudad de México, el establecimiento de un medio más rápido de distribución de sus productos, como era el ferrocarril, y la explotación de un nuevo producto en la región, como será la trementina.

\subsection{La urbanización de terrenos}

Entre 1900 y 1910 se crearon 28 colonias en el Distrito Federal. Para formar una era necesario cumplir con las Reglas para Admisión de Nuevas Colonias expedidas en 1903. Se exigía al propietario presentar un plano señalando el $10 \%$ de los terrenos que cedía a la comunidad para formar plazuelas, arbolados y mercados, además de que se comprometía ante notario a dotarla de agua potable, plantar árboles y asegurar la realización de las atarjeas.

Sin embargo, como se indica justamente en el título de la reglamentación, se habla de admisión y no de autorización, ya que en ocasiones las colonias se creaban sin estar autorizadas y los ayuntamientos, al no prohibir su construcción, se veían obligados posteriormente a "recibirlas" dotándolas de servicios.

En 1906, la Dirección General de Obras Públicas informó que el Ayuntamiento había autorizado la creación de seis colonias, 14 habían sido admitidas apenas por los municipios foráneos y seis no habían sido aceptadas por no cumplir con las reglas expedidas (Jiménez Muñoz 1993: 21-23).

Una de esas 14 colonias admitidas era la llamada La Viga o De Noriega. La zona que se proyectaba fraccionar medía alrededor de 300 mil metros cuadrados y estaba formada por terrenos que habían aportado Eduardo Zozaya a la Sociedad Noriega y Zozaya en 1891 y dos potreros en el barrio de La Candelaria, a un lado de la calzada de San Antonio Abad, que habían pertenecido al ex presidente Manuel González y a la Sociedad Ibáñez y Prieto. ${ }^{33}$

33 ANCM, notario Juan M. Villela, acta 116, México, 29 de septiembre 1898 , fs. $188-189$. 
En 1903, Íñigo Noriega hizo la primera solicitud para fraccionar el terreno de La Viga pero no fue aceptada. De cualquier manera, inició la construcción en los terrenos de lo que sería su fábrica de hilados y tejidos de algodón llamada "La Guadalupe". Posteriormente, Roberto Gayol con el poder de Noriega y como director de Obras Públicas presentó nuevamente una solicitud acompañada de planos de agua potable y saneamiento que tampoco fue aceptada, aunque el ayuntamiento aprobaba el fraccionamiento de calles y manzanas.

Los trabajos continuaron sin la aceptación oficial hasta que otros interesados se integraron al proyecto. Jacinto Pimentel, hermano del presidente municipal del Ayuntamiento de México, obtuvo la concesión para construir y explotar una línea de ferrocarril, que partiendo de la ex garita de La Viga siguiera hacia el este por la calzada de San Esteban para terminar en la colonia del rancho de La Viga (Jiménez Muñoz 1993: 36).

Para ello se formó en 1909 la Compañía Fraccionadora de los Ranchos de La Viga y La Magdalena, S.A. con un capital de 452.000 pesos. Al parecer los trabajos se paralizaron durante un tiempo, pues, en 1913, la Compañía Agrícola y Colonizadora Mexicana S.A. representada por José Armendáiz, yerno de Íñigo Noriega, reanudó las gestiones ante la Dirección General de Obras Públicas para retomar este proyecto (Jiménez Muñoz 1993: 38).

Como vemos en la evolución de este problema, no se trataba únicamente de la urbanización de la ciudad de México. Un informe aparecido en el Boletín Municipal del 24 de noviembre de 1922 nos lo sugiere:

[...] los problemas que el actual ayuntamiento presenta y se seguirán presentando [...] tuvieron su origen en los descuidos y lenidades de administraciones de otro tiempo, las que dejaron situaciones de tal manera complicadas que su allanamiento sin hipérbole, constituye el desenmarañamiento de una madeja de infracciones municipales y sanitarias y de intereses creados, que ya no pueden ser atacados ni destruidos [...] hacemos mención de la colonia de la Viga $[\ldots]{ }^{34}$

34 Boletín Municipal, dirigido por Adrián Villalba (México, 24 de noviembre de 1922). 


\subsection{El establecimiento del ferrocarril}

Desde 1893 la producción agrícola de estas dos propiedades agrícolas del valle de México alcanzaba la cifra de 18 mil toneladas, por ello los propietarios tuvieron el interés de construir transportes modernos. ${ }^{35}$

Según las apreciaciones de Auguste Genin (1908), la hacienda de Xico representaba en la época el granero de México gracias a la "inteligencia, la energía y la perseverancia de un español como Íñigo Noriega". De acuerdo con sus datos, esta propiedad aportaba anualmente a la alimentación de los capitalinos 38.000 pesos en leche, 14.000 en pulque, 130.000 en trigo y alfalfa, 1.230 .000 en maíz, que correspondía a 1.412 .000 pesos en total.

Genin afirmaba que los datos correspondían a ese año, pues eran susceptibles de cambio debido a que Noriega aumentaba continuamente el número de sus plantaciones de maíz y alfalfa, así como de sus vacas lecheras. Además, los terrenos de Xico tenían magnificas condiciones de comunicación, lo que aumentaba considerablemente su precio con los años.

Con este proyecto en mente se creó la Compañía del Ferrocarril de Xico y San Rafael que se unió a la Compañía de Papel San Rafael. El objetivo de ésta era construir y explotar una línea de comunicación entre México y Atlixco, beneficiándose de la línea construida por el Ferrocarril de Tlalmanalco (1881-1882). La nueva línea pasaría por la Compañía Agrícola de Xico S.A. hasta llegar a Amecameca y a Atlixco, pasando por los pueblos de Ozumba, Ecatzingo y Santa Catalina. De esta manera, la región de los volcanes contaría con una línea que conectaría sus dos flancos, Chalco al este y Atlixco al oeste, pero ligados a mercados más amplios, puesto que llegarían hasta la ciudad de México, haciendo un trayecto más corto que el del Interoceánico que rodeaba por Cuautla. Sin embargo, lo que es importante señalar en este proyecto modernizador es el tipo de materiales que se transportaron. $^{36}$

35 En 1819 las haciendas del distrito producen 31.500 cargas de maíz que no serán superadas sino en 1889 , cuando se producen 33.815. Hacia principios del nuevo siglo, con la innovación tecnológica en marcha, Ínigo Noriega anuncia cifras de producción de 200 mil cargas en sus haciendas, véase Tortolero (1995).

36 Un análisis más amplio de estos datos puede verse en Martínez Moctezuma/ Tortolero (2000). 
La vía de tren que utilizan los Noriega, antigua propiedad de los Zozaya, se transforma en 1891 cuando importantes grupos de inversionistas se apoderan del control y de las vías férreas regionales. En nuestro caso fueron la Compañía Agrícola de Xico y la Compañía de Papel de San Rafael las que crean la Compañía del Ferrocarril de Xico y San Rafael. El ferrocarril comienza su explotación en 1898 con $29 \mathrm{~km}$ en explotación comercial y en 1911 ya se extiende sobre 142 kilómetros. Los volúmenes anuales transportados por el ferrocarril crecen en el periodo como lo muestra el Cuadro 1, observando que este medio de transporte regional es más importante que los nacionales. En efecto, el Ferrocarril Central transporta en el estado en 1901 una carga de 64 mil toneladas, el Ferrocarril Mexicano mueve 100 mil toneladas en 1910, mientras que el Ferrocarril de San Rafael y Atlixco arrastra más de 120 mil toneladas en 1910 y en 1911 transporta 217 mil toneladas. Los principales productos que traslada son los forestales, siguiendo en importancia los agrícolas, donde el maíz, el pulque y el trigo son los principales rubros transportados. Se notaba, entonces, el interés de los Noriega por dar salida a los productos de sus empresas agrícolas.

\subsection{La explotación de la trementina}

En la explotación de la trementina, encontraremos a Íñigo Noriega impulsando proyectos educativos de capacitación, que en este contexto no sólo se orientaban hacia la formación del ciudadano, sino que "hacer al trabajador" también constituyó una de sus preocupaciones centrales. $^{37}$

Ínigo Noriega fue una pieza importante en el establecimiento de la Escuela Regional de Agricultura de Chalco en $1895,{ }^{38}$ prestando los terrenos y la maquinaria de su hacienda La Compañía para que los

37 Véase Eguiarte Sakar (1989: 14). Esta preocupación de mejorar la formación general y profesional de los trabajadores, con el fin de beneficiar a la propiedad con una mano de obra calificada y de valorar las producciones, se observa también para el caso europeo, a manera de ejemplo, véase Beaud (1995: 505506).

38 Para la historia de esta escuela agrícola, véase Martínez Moctezuma (1994) y, para otros proyectos educativos del empresario en Colombres, véase Uría (1984: $105-11)$ 
alumnos pudieran cursar todos los sábados la materia de Los Trabajos Prácticos de Agricultura. ${ }^{39}$

A pesar de contar con la maquinaria necesaria y con los conocimientos de quienes la usaban a diario, las clases sabatinas resultaron un fracaso, pues los alumnos no se presentaron a ellas. Ante los problemas que la escuela enfrentaba año con año, el Gobierno proyectó a fines de 1898 su transferencia a otro distrito. ${ }^{40} \mathrm{Si}$ el primer intento de capacitación de trabajadores había fracasado, en cambio los negocios del empresario cada día eran más importantes. Sus haciendas de Chalco se habían convertido, en poco más de una década, en modelo de explotaciones. Noriega no podía conformarse con un intento fallido y por ello hizo venir desde España mano de obra ya calificada que se hiciera cargo de las nuevas explotaciones que proyectaba implementar en sus haciendas de Zoquiapan y Río Frío.

En 1911, el horticultor Mariano Gajón se integró al personal que laboraba en las haciendas de Noriega. Ante el interés de introducir nuevos cultivos, como el de la explotación de montes de pino para extraer resina, el horticultor español estableció la necesidad de contar con obreros calificados para este trabajo. De esta manera, hizo venir desde España a varios trabajadores competentes en el oficio. ${ }^{41}$

Dentro de la zona boscosa de Zoquiapan y Río Frío existía el ejemplo del rancho de Ixtlahuacán, que alrededor de 1872 explotaba la

39 Ya en otro tiempo se vislumbraba la función de los hacendados en este terreno: "[...] todos los propietarios de explotaciones rurales deben persuadirse de que en su interés está el desarrollo de la instrucción agrícola; en los adelantos de la agricultura deben convencerse de que es imposible que ésta adelante si ellos no contribuyen con sus elementos y su influencia al mejoramiento de la industria rural, al sostenimiento de una escuela en su misma finca, en la que enseñen los rudimentos de la agricultura juntamente con los rudimentos del idioma, los elementos del cálculo y los deberes y derechos del ciudadano [...]" (Escuela de Agricultura 1880: 39).

40 Decreto núm. 44, Articulo único: "Se faculta al Ejecutivo para que, si lo cree conveniente, clausure la Escuela Regional de Agricultura establecida en Chalco, y destine el local a otro objeto que satisfaga los deseos del gobierno [...]", Toluca, 9 de mayo 1898 (Villada 1898).

41 Mariano Gajón era miembro de la Academia Universal de Ciencias y Artes Industriales, de la Sociedad Científica Europea, de la Sociedad Catalana de Horticultura y Vocal de la Cámara Agrícola de Zaragoza, entre otras (Gajón 1910). 
resina aunque siempre lo había hecho con resultados negativos. ${ }^{42}$ Era evidente que este método para extraer la trementina de los ocotes perjudicaba tanto al árbol como al dueño; a cambio de unos kilos, el árbol se hacía leña y el propietario no obtenía ni la décima parte de la trementina que se podía obtener (BSAM 1898: 203-205).

¿Pero cuál era el interés de Noriega en esta explotación? Tomemos como ejemplo el caso de la industria resinera en España, que a principios del siglo XX ocupó el tercer puesto en importancia a nivel mundial, tras los Estados Unidos y Francia, al exportar entre 1910 y 1913 un total de $63 \%$ de la esencia y un $45 \%$ de la colofonia.

Hacia esta época, la resina natural, miera o trementina era un producto que se explotaba ampliamente en los montes españoles. Su extracción era realizada por especialistas mediante incisiones practicadas en el tronco de coníferas. Tras su procesamiento mediante la destilación, se fabricaba la esencia de trementina o aguarrás y la colofonia o resina

El valor de la trementina se debía a sus propiedades como solvente de materias grasas. Durante mucho tiempo la fabricación de pinturas y barnices constituyó su principal uso industrial. Además, era utilizada en la limpieza de maquinaria, sobre todo en los barcos de vapor y en los ferrocarriles.

Para la colofonia, su uso más extendido era en la fabricación de jabón requerido en la industria textil y a principios del siglo XIX se inició su uso en la producción de papel. Las grasas elaboradas a base de colofonia eran principalmente empleadas como lubricantes en los carruajes, ferrocarriles, engranajes de maquinaria, etc. Su principal cualidad era mantener su consistencia durante mucho tiempo, con lo cual podía emplearse en cualquier época del año (Uriarte Ayo 1995: 509-512).

En 1904, el semanario El Economista Mexicano insistía en que esta industria tenía un gran porvenir en el país por dos razones: por una parte, la producción en Estados Unidos había disminuido a tal grado

42 En ese año se informaba de los estragos producidos a causa de la mala extracción de la trementina: "[...] por el mal método que para esto se ha observado, ha sido causa de la caída de un número considerable de los mejores árboles y que otra gran cantidad de ellos se encuentran carbonizados y secos por el incendio de las hojas secas que frecuentemente acontece en el verano [...]", AGN, Caja de Préstamos, vols. 92-97, exp. 280, f. 89. 
que no se exportaba más trementina de los estados de Carolina del Sur y Georgia, debido a la explotación inapropiada que había originado la pérdida de muchos árboles; por otra parte, se aseguraba que el país contaba con un gran número de árboles resinosos con lo cual se motivaba a los agricultores a iniciar su explotación.

Efectivamente, la producción norteamericana había empezado a sufrir grandes contratiempos. En vísperas de la Primera Guerra Mundial, la quiebra de la American Naval Stores, de Savannah, una de las empresas más importantes de la industria resinera mundial, y la guerra de los Balcanes (1912-1913) transformaron los mercados europeos.

Con este panorama, era evidente el interés de Noriega por aprovechar una parte de sus terrenos montañosos en la explotación de un producto que le beneficiaría en sus inversiones textiles y en los medios de transporte e intentar el ingreso a un mercado externo sin líderes.

Fue así que, no pudiendo contar con los técnicos especializados egresados de la Escuela Regional de Agricultura de Chalco, buscó emplear a aquellos que ya contaran con la formación debida. Fue el caso de los 54 contratos con obreros resineros que llegarían de las provincias de Ávila, Segovia, Madrid y Cuenca. ${ }^{43}$

Los contratos se establecieron de marzo de 1911 hasta abril de 1913. Los trabajadores llegaron a México con un contrato mínimo de tres años, el viaje era pagado en tercera clase en un vapor alemán desde Santander hasta Veracruz y por ferrocarril hasta la hacienda. ${ }^{44}$ Con un salario que variaba de dos a seis y media pesetas diarias,

más 70 centavos diarios comprendiendo los días festivos para su alimentación que equivale a más de tres pesos mexicanos por cada día hábil de trabajo, jornal mayor que el que disfrutan en sus pueblos $[\ldots] .^{45}$

Parte de ese salario podían recibirlo las familias de los trabajadores residentes en España, a través del Banco de España de su provincia.

43 AMAEM, Sección Política, 1913, leg. 2558.

44 Carta del señor José Armendáiz, gerente de la Compañía Agrícola y Colonizadora Mexicana S.A. al señor Emilio Moreno, cónsul general de España en México, AGACE, caja 9.651, 1913, f. 2.

45 Cabe señalar que a finales del siglo XIX se localizaban en el estado de México aproximadamente 120.000 trabajadores agrícolas que percibían un salario que oscilaba entre 15 y 37 centavos diarios. En Chalco existían 9.747 peones que recibían un salario de 25 a 31 centavos diarios por diez horas de trabajo (Villada 1894: 333-364). 
Estos salarios eran más bajos que los que se pagaban en Estados Unidos pero más altos que los pagados en España en ese momento. En la región de Castilla se recibía un promedio de 2,00 a 2,25 pesetas, por lo que resulta evidente el interés de estos obreros (Tortella Casares et al. 1981: 279, 414).

Sin embargo, la situación revolucionaria en México no permitió el desarrollo de este tipo de proyectos. En mayo de 1913 el Consulado Español en México recibía la primera noticia de los disturbios zapatistas en la hacienda de Zoquiapan; las propiedades fueron invadidas y el pago de las deudas ignoradas.

\subsection{Propiedades en el norte de México}

El interés de Noriega se centró en la región del Nuevo Santander (Tamaulipas a partir de 1824) denominada "El Sauto", que la voz popular cambió por "La Sauteña". Esta extensa propiedad de aproximadamente 1.154.790 ha, mayor que entidades como Morelos y Tlaxcala, fue modificando su apariencia y extensión con el paso de diferentes propietarios. En esta región, Noriega se propondrá tres objetivos: obtener a toda costa el mayor número de acciones dentro de la sociedad con el fin de imponer sus estrategias empresariales; crear una sociedad anónima por 99 años con el fin de impulsar la irrigación, la colonización, el fraccionamiento de predios rústicos, la explotación agrícola e industrial, así como la construcción de vías de comunicación y, finalmente, gozar de subvenciones por el uso del agua y contar con el apoyo financiero de la banca estatal y privada para llevar a cabo estos proyectos modernizadores.

La historia de la propiedad se inicia cuando en 1871 fue cedida en venta al señor Antonio de Urízar, comerciante y propietario de la ciudad de México, quien la fragmentó por primera vez. Después pasó a manos de la familia Conde y por último a las de un grupo de empresarios españoles, quienes realizaron la compra motivados por Demetrio Salazar.

Salazar era egresado del Instituto Científico y Literario de San Juan, abogado e íntimo amigo de Manuel González y Porfirio Díaz (Herrera Pérez 1993). Gozando de estos vínculos, pronto obtuvo un contrato con la Secretaría de Fomento, que le autorizaba en 1886 a deslindar terrenos baldíos. Fue así que se interesó en adquirir la pro- 
piedad de "El Sauto", para llevar a cabo su convenio con el Gobierno, por lo que buscó apoyo financiero de otros empresarios que se encargarían de la compra del terreno, entre ellos se encontraba un fuerte grupo de asturianos: Ibáñez y Compañía, Ignacio de Noriega y Compañía, Indalecio Sánchez Gavito y por supuesto la Sociedad Remigio Noriega y Hermano. ${ }^{46}$

Dispuestos a explotar al máximo su potencial, la sociedad ordenó al norteamericano W. F. Cummins una exploración geológica de la propiedad en 1897 , con miras a descubrir yacimientos de hidrocarburos. Estos trabajos comenzaron al mismo tiempo que los agrícolas y los de colonización. Hacia 1905, a pesar del éxito de los trabajos, los problemas personales comenzaron a manifestarse; la figura de Demetrio Salazar, considerado el socio fundador de la compañía, parecía impedir la libertad de acción a Íñigo Noriega. Su relación personal se había deteriorado no sólo a causa del manejo que éste había hecho de 300.000 ha de terreno ubicadas en el estado de Chihuahua, sino que además Noriega había acaparado paulatinamente el control de la sociedad.

Los terrenos en cuestión se encontraban clasificados como propiedad de la nación. Le fueron vendidos a Noriega por 15 centavos la hectárea por el geógrafo Antonio Peñafiel, quien los había recibido a cambio de ceder su obra Monumentos del Arte Mexicano Antiguo, para la Exposición Universal de París. Porfirio Díaz ratificó la venta:

Por tanto, mando a las autoridades del estado de Chihuahua y a los demás de la República, que no pongan ningún obstáculo al mismo Sr. Íñigo Noriega, en la propiedad que se le concede; sino antes bien, lo mantengan en el libre uso, aprovechamiento, dominio y posesión que le corresponden $[\ldots]^{47}$

Íñigo Noriega tomó muy en serio estas indicaciones, pues a la larga el manejo que hizo de ellas le llevó a tener problemas con Salazar. Para poder comprar esta propiedad, se habían unido con un $30 \%$ de los derechos Antonio Basagoiti y los hermanos Remigio e Íñigo Noriega, así como, con un 10\%, Demetrio Salazar.

46 Para mayor información, véase ANCM, notario Juan M. Villela, acta 1.908, México, 13 de marzo 1913 y actas 2.008, 2.913, 3.029 y 3.038, México, 30 de octubre 1907.

47 ANCM, notario Juan M. Villela, anexo de 1888 (sin otra referencia). 
En 1906 Íñigo cedió y enajenó 250.104 ha de esta propiedad a su hermano Remigio por la cantidad de 12.100 pesos, lo que haría aproximadamente un pago de cinco centavos por hectárea. Si recordamos que su antiguo dueño había pagado 15 centavos por hectárea, no parece extraño encontrarnos con las actas judiciales a las que se sometieron las reclamaciones de Salazar sobre los beneficios que había producido la venta de estos terrenos. ${ }^{48}$

Para lograr el dominio total de la sociedad, los Noriega intercambian acciones de una compañía por otra. Por ejemplo en 1903, la sociedad "C. Noriega y Compañía" cedió a los hermanos Noriega 17 partes de La Sauteña a cambio de 1.371 acciones de la Compañía Agrícola de Xico. En la permuta no se consideraba el valor nominal de las acciones, pues se aclaraba que el propósito de Noriega era únicamente "[...] aumentar su anterior representación [...] y poder llevar a mejor término las diversas operaciones agrícolas recientemente proyectadas [...]" en La Sauteña. ${ }^{49}$

Con esta acción y otras que realizó posteriormente, Noriega adquirió el dominio de las 115 partes en que estaba dividida la sociedad: 36 a M. Ibáñez y Compañía, 36 a Remigio Noriega y Hermano, 17 a Ignacio de Noriega, 16 al licenciado Sánchez Gavito y 10 a Demetrio Salazar. Si sumamos a su favor las 17 partes que ahora se permutaban, más las 36 partes que le fueron cedidas a Íñigo Noriega en 1904 por los herederos de Manuel Ibáñez, más las 10 partes a las que renunciaba el licenciado Salazar en abril de 1905, además de las 36 que originalmente le correspondían en su haber por la Sociedad Remigio Noriega y Hermano, nos damos cuenta de que en dos años se convierte en el socio mayoritario con casi el $90 \%$ de las acciones. ${ }^{50}$

Eliminados Demetrio Salazar y el resto de los accionistas, Íñigo Noriega se propuso en 1907, junto con Sánchez Gavito, llevar a cabo sus proyectos modernizadores: crear una sociedad anónima llamada Compañía Agrícola La Sauteña, S.A., domiciliada en la ciudad de México y con duración de 99 años. Sus objetivos eran más ambiciosos, pues además de la explotación agrícola, la irrigación, la colonización y fraccionamiento de sus predios rústicos, se esperaba impulsar la

48 ANCM, notario Juan M. Villela, acta 142, México, 17 septiembre 1906.

49 ANCM, notario Juan M. Villela, acta 2.804, México, 28 de febrero 1907.

50 ANCM, notario Juan M. Villela, acta 829, México, 15 de marzo 1903 y acta 3.038, México, 11 de abril 1907. 
explotación industrial de los productos al igual que la construcción de vías de comunicación y el transporte de pasajeros y de carga por vías marítimas, fluviales y terrestres, aprovechando sus ríos y su extensión que para esta época era ya de 810.000 ha de superficie.

Su valor en bienes ascendía a 10.000 .000 de pesos según lo acreditaba el dictamen del perito, su amigo y socio, el ingeniero Roberto Gayol, quien había evaluado en 8.830 .000 pesos el valor predial del terreno, tomando en cuenta la expansión superficial, sus condiciones climatológicas, topográficas e hidrológicas, muy similares a las que se encontraban del otro lado del Río Bravo. ${ }^{51}$

Su valor estaba representado en 100.000 acciones, de las cuales Íñigo Noriega poseía tan sólo 88.500 , que le permitía, además de tener el más alto número de representaciones, ocupar el puesto de gerente general, ${ }^{52}$ pues el consejo de administración lo había nombrado con el fin de darle amplias facultades. ${ }^{53}$

Una de las primeras decisiones de Noriega fue suscribir un contrato con el Gobierno del estado, donde se comprometía a emprender trabajos agrícolas a cambio de utilizar el agua de los ríos, de la lluvia, de las presas y de los pozos artesianos; construir presas y desmontar terrenos para cultivar 10.000 ha; cercar potreros, introducir maquinaria, y efectuar obras necesarias para el establecimiento de colonias agrícolas, aparte de la producción pecuaria de la propiedad. ${ }^{54}$

51 Otras opiniones, como la del corredor Mariano Levy, le asignaba un valor de 40.729 pesos en la inversión de los pozos artesianos, 72.632,07 pesos en los estudios hechos para los trabajos de irrigación, $9.559,42$ pesos en la existencia de mercancías y $65.123,15$ pesos en créditos activos, entre los que se encontraban préstamos a particulares (4.744 pesos), a dependientes y sirvientes $(31.799,62$ pesos), a José Duvallon (19.860 pesos), más los anticipos a jornaleros $(8.416,04$ pesos) y a contratistas de terrenos (302,50 pesos). En el pasivo se encontraban saldos a favor de su yerno Francisco Armendáiz y Sucesores y a nombre del mismo Roberto Gayol (ANCM, notario Juan M. Villela, acta 3.038, México, 2 diciembre 1906).

52 El grupo de accionistas se componía de los señores Indalecio Sánchez Gavito (11.000 acciones), Francisco Yarza, Luis Barroso Arias, Fernando Pimentel y Fagoaga, Vicente Barreneche e Íñigo García Borbolla con 100 acciones cada uno, ANCM, notario Juan M. Villela, acta 38, México, 23 de julio 1907.

53 ANCM, notario Juan M. Villela, acta 3.084, México, 24 de mayo 1907.

54 Un viajero de la época señalaba la importancia de los trabajos, pues en su opinión se trataba de terrenos áridos que necesitaban absolutamente ser regados, por lo que se hablaba de una fuerte subvención del Gobierno para emprender las obras 
El Gobierno por su parte le otorgaba franquicias por el uso del preciado líquido de las aguas de los ríos Bravo, San Juan y Conchos ó San Fernando, así como la laguna Anda La Piedra y las presas que se construyeran en los estados de Tamaulipas y Nuevo León, asimismo la exención de impuestos por veinte años al capital invertido y a las industrias establecidas, siempre y cuando consumieran productos de la misma propiedad. ${ }^{55}$

Además de explotar con éxito la ganadería -150 mil cabezas de ganado y 4.000 caballos-, esta sociedad veía su futuro en la colonización de tierras y en el cultivo del algodón, pues con la cosecha de un sólo año pretendían pagar los 25.000.000 de pesos que calculaban para financiar las obras de riego, aunque también se proyectaba el cultivo de otros productos semitropicales -caña de azúcar, tabaco, arroz- y el maíz en 200.000 ha de terreno destinadas para ello. Para transportar la producción se contaba con la línea del Ferrocarril Nacional que pasaba por el norte de la propiedad, aunque se tenía también el proyecto de construir un ramal que atravesara la propiedad de norte a sur y el transporte marítimo, tocando los puertos de Tampico, Veracruz, Alvarado, Coatzacoalcos y Progreso (Trentini 1908: 152-156).

Con todos estos proyectos en puerta, era evidente la necesidad de contar con un buen apoyo financiero, por lo que pronto hicieron contacto con empresarios norteamericanos a través de la Texas Company, con la Caja de Préstamos para Obras de Irrigación y Fomento a la Agricultura y con la banca privada, por medio del Banco Agrícola e Hipotecario de México.

Debido a los conflictos políticos que empezaban a manifestarse en el país, Noriega implementó una nueva estrategia para realizar sus objetivos: diversificar sus actividades productivas poniendo en práctica la cláusula quinta de la escritura constitutiva, a través de la cual se capacitaba a la sociedad para formar otras nuevas o la cooperación con ellas en negocios de interés común. De esta manera se crearon dos nuevas compañías, una orientada al comercio y otra a la producción agrícola y a la colonización: El Nuevo Mundo Sociedad Anónima de Chihuahua y la Compañía Agrícola de Colombres, S.A.

de riego con el fin de aumentar la población, que no llegaba a 250 mil habitantes, con colonos europeos (Dollero 1911: 184).

55 ANCM, notario Juan M. Villela, acta 4.176, México, 15 de enero 1909 y Herrera Pérez (1993: 15-17). 
La primera tenía su domicilio en la ciudad de México y en 25 años lograría cuatro objetivos: adquirir y enajenar con propósito de especulación comercial artículos muebles o mercaderías nacionales o extranjeras en la ciudad de Chihuahua o en cualquier otro lugar de la República; adquirir o arrendar edificios para tiendas, almacenes o bodegas; concurrir a la formación de sociedades anónimas y cooperar con comerciantes del mismo ramo o de la misma localidad en negocios de utilidad común.

Su capital era de 1.000.000 de pesos, representado en 10.000 acciones al portador a nombre de la Sociedad en Comandita Bünsor y Gutiérrez (6.800 acciones), Íñigo Noriega (3.000) y Adolfo Prieto e Hipólito Gerard (100 acciones). En el artículo trigésimo tercero de los estatutos se aclaraba que entre las funciones del gerente general se encontraban las de ejecutar las órdenes del consejo de administración y prestar toda su actividad y conocimientos comerciales en los negocios de la sociedad, por lo que quedaba prohibido estrictamente ocuparse de negocios extraños a la compañía o formar parte como administradores o gerentes en otras sociedades, quizá por esta razón Noriega no participó oficialmente a la cabeza de esta compañía aún cuando contaba con una tercera parte de las acciones.

Por su parte, la Compañía Agrícola de Colombres S.A. tenía los mismos objetivos que "La Sauteña": la enajenación, hipoteca y gravamen de los bienes que constituían su activo, la concesión gratuita $\mathrm{u}$ onerosa de fracciones de terreno a colonos y el cumplimiento de las obligaciones contraídas con los norteamericanos A. C. Swanson, E. R. Brooks y E. F. Rowson, de la Texas Company.

Este último convenio pretendía ligarla con la élite económica y política de Texas, a través de la concesión que les otorgaban para promover en Estados Unidos y Europa la colonización y venta de tierras de La Sauteña. El paso de la Texas Company por México fue muy provechosa para ella, pues adquirieron 1.800 .000 ha donde sólo 800.000 ha eran de La Sauteña y estaban valuadas en 26.000.000 de pesos, más 3.000 .000 de pesos en que se contabilizaban los derechos por pensiones de agua y por subvenciones. A cambio de estas libertades, la compañía norteamericana se propuso apoyar al presidente Díaz con 25.000.000 de dólares que sirvieron para el impulso a la agricultu- 
ra de riego y para fundación del capital social de la Caja de Préstamos para Obras de Irrigación y Fomento a la Agricultura. ${ }^{56}$

Dada su importancia económica, la Colombres se estableció con un capital de 20.000.000 de pesos, representado por 200.000 acciones liberadas al portador con valor nominal de 100 pesos cada una. Las acciones se suscribieron de la siguiente manera: 199.965 para la Compañía Agrícola La Sauteña y cinco para cada uno de los accionistas. ${ }^{57}$

Creada el 15 de noviembre de 1910 tuvo que cambiar su nombre de Colombres por el de Compañía Agrícola de Río Bravo, con la intención de poder negociar su existencia con el régimen maderista. Lo que resultó positivo, pues en 1912 logró obtener un préstamo por 5.000.000 de pesos de la Caja de Préstamos, necesarios para amortizar el pasivo y llevar a cabo los proyectos de abrir al riego 1.000 .000 ha de terreno, fraccionar y colonizar 25.000 ha a cambio de renunciar a una subvención de 6.000 .000 de pesos que debía darle el Gobierno federal. $^{58}$

Como garantía, la compañía agrícola otorgó a la Caja una hipoteca en primer grado de sus bienes raíces que consistían en una vasta extensión de terreno árido e improductivo a cuya irrigación estaba destinado el préstamo. Simultáneamente con esta operación, la compañía agrícola lanzó una emisión de bonos por valor de 16.500 .000 pesos garantizados con la hipoteca en segundo grado sobre los mismos bienes hipotecados. Estos bonos fueron tomados en su totalidad por el Banco Central Mexicano, a pesar de que sus peritos habían aclarado que "no tendrían valor alguno a menos que se ejecutaran las obras de irrigación proyectadas" y dudaban de su utilidad debido a "las íntimas conexiones" que los unían.

Con la Revolución mexicana, la Compañía de Río Bravo prácticamente detuvo sus actividades e Íñigo Noriega abandonó el país, de ahí que su compromiso con la Caja de Préstamos no pudiera ser cumplido. En 1920 la Caja entabló una demanda contra la compañía por

56 ANCM, notario Juan M. Villela, acta 5.261, México, 12 enero 1910 y Herrera Pérez (1993: 20).

57 Cada uno los accionistas era propietario de cinco partes, a saber, Íñigo Noriega, Indalecio Sánchez Gavito, Jacinto Pimentel, Fernando Pimentel y Fagoaga, Telésforo García, Eutimio Cervantes y José Zubieta, ANCM, notario Juan M. Villela, acta 5.261, México, 16 de agosto 1910.

58 AHSRE, exp. 17-12-81. 
3.440.714,37 pesos que correspondía al capital adeudado y a los intereses que se habían generado hasta entonces, por lo que obtuvo la posesión judicial de los bienes.

Los tiempos políticos habían cambiado y la situación para el empresario no estaba segura. Noriega se vio obligado a partir al exilio primero hacia España y luego a Estados Unidos. Uno de sus enemigos, Mariano Duque, inició una campaña en su contra argumentando la venta ilícita de varios terrenos en la ciudad de México, y el presidente Huerta también se encontraba tras sus huellas. Murió el 4 de diciembre de 1920 en casa de su hija Guadalupe en la ciudad de México. ${ }^{59}$

\section{Consideraciones finales}

Publicaciones de la época describieron a este tipo de personajes, hombres de empresa que se acercaban mucho a la imagen de Íñigo Noriega y de sus propiedades. En ellas se caracterizaba al hacendado como aquel que montaba a caballo y visitaba sus propiedades para asegurarse que cada uno cumpliera con su tarea. Que igual centralizaba la dirección del cultivo y su fabricación, cuidaba de preparar las entregas, se aseguraba del control de los precios y cobraba las cuentas.

Para Roland Bonaparte (1904), los hacendados no estaban en contra de las leyes del progreso, pues ellos mismos habían introducido y aplicado métodos nuevos, favorecido la inmigración, fundado nuevas manufacturas para utilizar y convertir la materia prima y creado sociedades para las empresas superiores a sus fuerzas.

Eso era exactamente lo que había hecho Íñigo Noriega con sus propiedades agrícolas. Adquiriendo una cantidad considerable de buenas tierras en el centro y en el norte del país, constituyó sociedades anónimas para arriesgar su capital en proyectos difíciles de emprender de manera individual. Estos proyectos tenían como objetivo explotar las propiedades con la maquinaria más moderna de la época, contar con el apoyo técnico de personal y de la mano de obra calificada para los nuevos cultivos que quería realizar como la trementina, por ello hizo venir a trabajadores calificados en el ramo, con lo cual favoreció

59 La muerte de Noriega se produjo, en la casa de Havre núm. 35 de su yerno Félix Martino, a causa de una enfermedad hepática (Alborada 1993). 
la inmigración en un país cuya preocupación era, a finales del siglo XIX, la falta de brazos.

Como ha señalado Bernecker (1992: 181-184), estas estrategias no eran ajenas a las de los comerciantes empresarios de la época, por lo que el comportamiento innovador de Noriega resulta acorde con las "leyes del progreso". En este sentido cabría hacer una última reflexión en torno a Noriega como empresario agrícola. En un documento de la época sobre su propiedad llamada Colombres, situada a 7 millas de Brownsville, se decía:

[...] [Noriega] se propone darle el mayor desarrollo posible a la agricultura [...] se ha instalado ya una bomba para irrigar [...] se ha limpiado el terreno y se ha plantado algodón [...] los métodos más modernos de agricultura han sido instalados [...] tractores de gasolina y otras maquinarias modernas [...] el desarrollo de la finca está en manos, no de un novicio sino de un hombre que es un perfecto conocedor de agricultura $[\ldots]^{60}$

Por lo tanto, si el hacendado moderno, tal y como lo definían Bonaparte (1904) y Santiesteban (1903), era aquel que se arriesgaba y que preparaba sus tierras con arados americanos, sembraba con aparatos y hacía el corte y la trilla con moderna maquinaria, entonces no cabe ninguna duda de que Íñigo Noriega fue un agricultor moderno que impulsó el desarrollo capitalista en México a finales del siglo XIX (Santiesteban 1903).

\section{Bibliografía}

Alborada (1993): Alborada. Colombres, Asturias: Publicaciones de la Asociación Cultural de Ribadedeva.

Álvarez Quintana, Covadonga (1986): "Emigración asturiana a ultramar y arquitectura. Parte 1. La emigración". En: Boletín del Instituto de Estudios Asturianos, 40, 117, pp. 243-269.

Anes Álvarez, Rafael (1993): La emigración de asturianos a América. Colombres, Asturias: Fundación Archivo de Indianos.

Beaud, Claude (1995): “L'innovation dans les établissements Schneider, 1837-1960". En: Histoire, économie et société, 14, 3, pp. 501-518.

Bermejo Lorenzo, Carmen (1998): Colombres y los hermanos Ybáñez Posada. Colombres, Asturias: Fundación Archivo de Indianos.

Bernecker, Walther (1992): De agiotistas y empresarios. En torno de la temprana industrialización mexicana. México, D.F.: UIA.

60 APFSM, sin referencia. 
Bojórquez, Juan de Dios (1932): La inmigración española en México. México, D.F.: Edición Especial Crisol.

Bonaparte, Roland (1904): Le Mexique au début du XXe siècle. Paris: Ch. Delegrave. BSAM (1879-1913): Boletín de la Sociedad Agrícola Mexicana (México), vols. 1-35.

Cerutti, Mario (1995): Empresarios españoles y sociedad capitalista en México (1840-1920). Colombres, Asturias: Fundación Archivo de Indianos.

Cerutti, Mario/Barragán, Juan Ignacio (1993): Juan F. Brittingham y la industria en Mexico, 1859-1940. Monterrey: Urbis Internacional.

Correo Español, El (1904): El Correo Español (México), año 1904.

Chassagne, Serge (1980): Oberkampf. Un entrepreneur capitaliste au Siècle des Lumières. Paris: Aubier Montaigne.

Dollero, Adolfo (1911): México al día. Paris: C. Bouret.

Drucker, Peter (1985): Les entrepreneurs. Paris: L'Expansion.

Eguiarte Sakar, M. ${ }^{a}$ Estela (ed.) (1989): Hacer ciudadanos. Educación para el trabajo manufacturero en el $s$. XIX en México. México, D.F.: UIA.

Escuela de Agricultura, La (1880): La Escuela de Agricultura (México), año 1880.

Figueroa Doménech, J. (1899): Guía general descriptiva de la República Mexicana. Barcelona: S. N. Araluce.

Gajón, Mariano (1910): Establecimiento de Arboricultura. Zaragoza, España.

García Luna, Margarita (1981): Haciendas porfiristas en el Estado de México. México, D.F.: UAEM.

Genin, Auguste (1908): Notes sur le Mexique. México, D.F.: Lacaud.

Gibson, Charles (1967): Los Aztecas bajo el dominio español, 1519-1810. México, D.F.: Siglo XXI.

González Loscertales, Vicente (1979): "Bases para el análisis socioeconómico de la colonia española de México en 1910". En: Revista de Indias, 39, 155-158, pp. 267-295.

- (1983): "El empresariado español en Puebla (1880-1916). Surgimiento y crisis de un grupo de poder". En: Capitales, empresarios y obreros europeos en América Latina. Actas del $6^{\circ}$ Congreso de AHILA, 198I, vol. 2. Estocolmo: Instituto de Estudios Latinoamericanos de la Universidad, pp. 468-492.

Hale, Charles A. (1991): La transformación del liberalismo en México a fines del siglo XIX. México, D.F.: Vuelta.

Herrera Pérez, Octavio (1993): "Del señorío a la posrevolución. Evolución histórica de una hacienda en el noreste de México: el caso de La Sauteña". En: Historia Mexicana, 43, 1, pp. 5-47.

Herrero, Carlos (1999a): Jerónimo Arango. Un empresario moderno. México, D.F.: UAM.

- (1999b): Joaquín Suárez y Suárez y Manuel Suárez y Suárez. Una familia, varios caminos, muchas empresas. México, D.F.: UAM.

- (2000): Adolfo Prieto y Carlos Prieto. Fundidora de Monterrey. México, D.F.: UAM. 
- (2002): Braulio Iriarte. De la Tahona al holding internacional cervecero. México, D.F.: UAM.

Jiménez Muñoz, Jorge (1993): La traza del poder. Historia de la politica y los negocios urbanos en el DF. De sus origenes a la desaparición del Ayuntamiento (1824-1928). México, D.F.: Codex.

Kicza, John (1986): Empresarios coloniales. Familias y negocios en la ciudad de México durante los borbones. México, D.F.: FCE.

Lida, Clara (1994): Una inmigración privilegiada. Comerciantes, empresarios y profesionales españoles en México en los siglos XIX y XX. Madrid: Alianza.

Liehr, Reinhard (1996): "Andrés Torres, comerciante y empresario de Puebla entre mercado interno mexicano y economía atlántica, 1830-1877”. En: Ibero-Amerikanisches Archiv, 22, 1/2, pp. 103-129.

Martínez Moctezuma, Lucía (2001): Iñigo Noriega Laso. Un emporio empresarial. Inmigración y crecimiento económico, 1868-1913. México, D.F.: UAM

Martínez Moctezuma, Lucía (ed.) (1994): Indios, peones, hacendados y maestros. Viejos actores para un México nuevo, 1821-1943. 2 vols., México, D.F.: UPN.

Martínez Moctezuma, Lucía/Tortolero, Alejandro (2000): "Les limites de la modernisation porfirienne. Chemin de fer et marché dans le bassin de Mexico (18801911)". En: Cahiers des Amériques Latines, 34, 2, pp. 119-138.

Morales Saro, María Cruz (1988): "Las fundaciones de los indianos en Asturias". En: Sánchez-Albornoz, pp. 66-79.

Morales Saro, María Cruz/Llordén Miñambres, Moisés (eds.) (1992): Arte, cultura y sociedad en la emigración española a América. Oviedo: Universidad de Oviedo.

Mörner, Magnus (1992): Aventureros y proletarios. Los emigrantes en Hispanoamérica. Madrid: MAPFRE.

Noriega Gayol, María Elena (1992): "Íñigo Noriega. Una vida, un indiano". Trabajo mecanografiado.

Ojeda, Germán/San Miguel, José Luis (1985): Campesinos, emigrantes, indianos. Emigración y economía en Asturias, 1830-1930. Salinas, Asturias: Ayalga.

Pérez de Sarmiento, Marisa/Savarino Roggero, Franco (2001): El cultivo de las élites. Grupos económicos y políticos en Yucatán en los siglos XIX y XX. México, D.F.: CONACULTA.

Pérez-Prendes y Muñoz de Arraco, José M. (1993): El marco legal de la emigración española en el constitucionalismo. Un estudio histórico-jurídico. Colombres, Asturias: Fundación Archivo de Indianos.

Pérez Vejo, Tomás (1984): "Indianos en Cantabria". En: Indianos. Oviedo: Caja de Ahorros de Asturias, pp. 17-25.

Piqueras, José A. (1994): "De la biografía tradicional a la historia individual, grupal y masiva". En: Carasa Soto, Pedro (ed.): Élites. Prosopografia contemporánea. Valladolid: Universidad de Valladolid, pp. 53-62.

Sánchez-Albornoz, Nicolás (ed.) (1988): Españoles hacia América. La emigración en masa, 1880-1930. Madrid: Alianza. 
Sánchez-Albornoz, Nicolás/Llordén, Moisés (eds.) (2003): Migraciones iberoamericanas. Reflexiones sobre economía, política y sociedad. Colombres, Asturias: Fundación Archivo de Indianos.

Santiesteban, J. B. de (1903): Indicador particular del administrador de hacienda, 2. ${ }^{a}$ ed. Puebla: Imprenta Artística.

Síndico, Doménico, et al. (eds.) (1985): El siglo XIX en México. Cinco procesos regionales. Morelos, Monterrey, Yucatán, Jalisco y Puebla. México, D.F.: Claves Latinoamericanas.

Tortella Casares, Gabriel, et al. (1981): Revolución burguesa, oligarquía y constitucionalismo (1834-1923). Historia de España, vol. 8. Barcelona: Editorial Labor.

Tortolero Villaseñor, Alejandro (1995): De la coa a la máquina de vapor. Actividad agrícola e innovación tecnológica en las haciendas de la región central de México, 1880-1914. México, D.F.: Siglo XXI.

- (2000): ¿¿Revolución agrícola en Chalco?”. En: Hiernaux, Daniel, et al. (eds.): La construcción social de un territorio emergente. El Valle de Chalco. México, D.F.: El Colegio Mexiquense.

- (2001): Empresarios y navegación en la Cuenca de México. La importancia de los canales en los siglos XVIII y XIX. México, D.F.: UAM.

Tortolero Villaseñor, Alejandro (ed.) (1993): Entre lagos y volcanes. Chalco-Amecameca, pasado y presente. México, D.F.: El Colegio Mexiquense.

Trentini, François (1908): La prospérité du Mexique. Paris: Librairie Boyveau \& Chevillet.

Uría, Jorge (1984): "Los indianos y la instrucción pública en Asturias". En: Indianos. Oviedo: Caja de Ahorros de Asturias.

Uriarte Ayo, Rafael (1995): "La industrialización del bosque en España interior: producción y cambio técnico en la industria resinera (1860-1914)". En: Revista de Historia Económica, 13, 3, pp. 509-551.

Uribe Salas, José Alfredo (2003): Empresarios del metal amarillo en México, 18981938. México, D.F.: UAM.

Villada, José Vicente (1894): Memoria que el C. Gobernador Constitucional del Estado de México presenta a la H. Legislatura del mismo, dando cuenta de sus actos administrativos durante el cuatrienio 1889-1893. Toluca: Imprenta de la Escuela de Artes y Oficios.

- (1898): Memoria que el C. Gobernador Constitucional del Estado de México presenta a la $H$. Legislatura del mismo, dando cuenta de sus actos administrativos durante el cuatrienio 1893-1897. Toluca: Imprenta de la Escuela de Artes y Oficios.

Yáñez Gallardo, César (1994): La emigración española a América (siglos XIX y XX). Dimensión y características cuantitativas. Colombres, Asturias: Fundación Archivo de Indianos. 

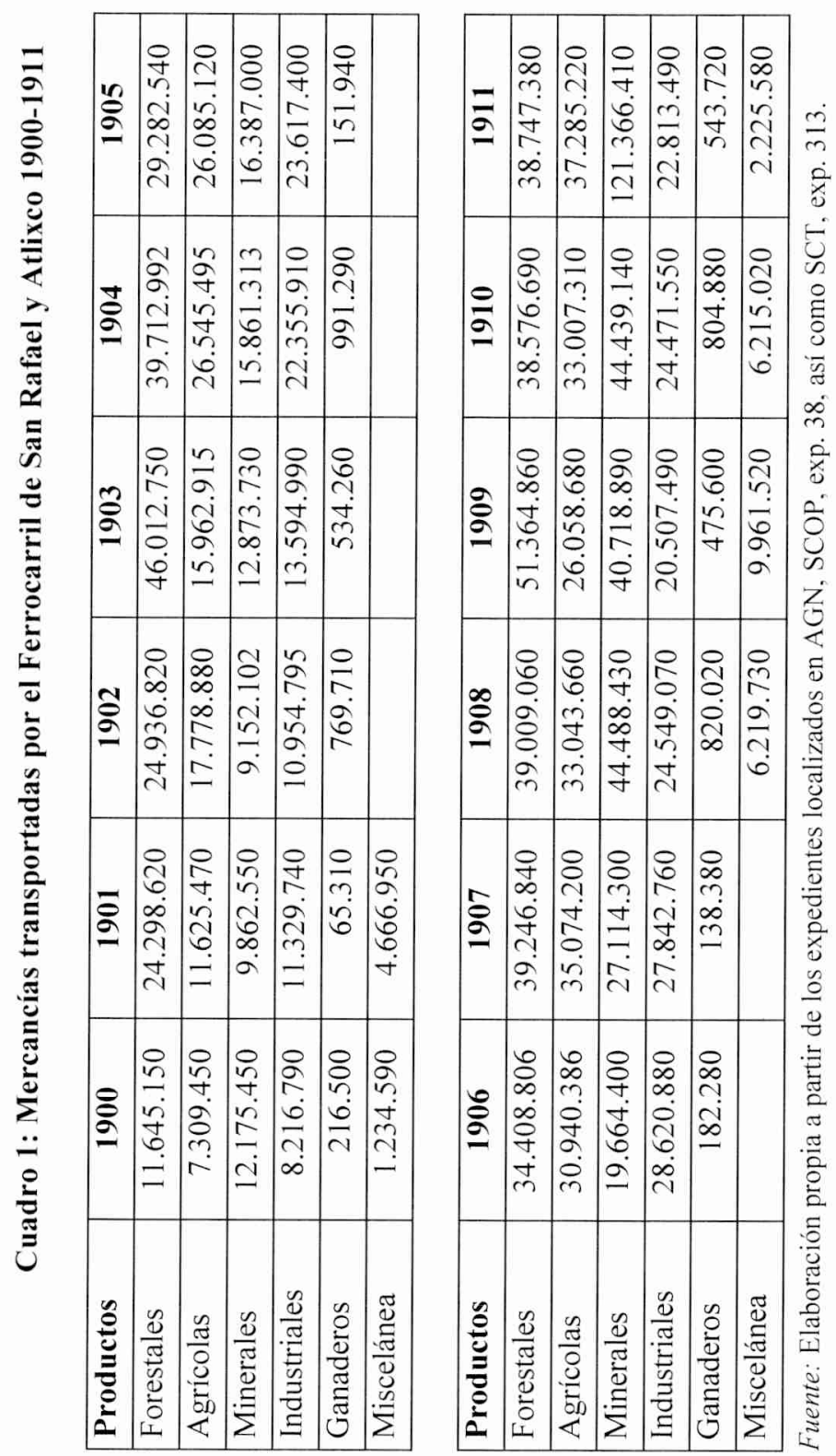



\section{Abreviaturas}

ACMRF Archivo de Carlos Martínez del Río Fernández, México, D.F.

AGACE Archivo General de la Administración de Colombres, Colombres, Asturias

AGI Archivo General de Indias, Sevilla

AGN Archivo General de la Nación, México, D.F.

AHEJ Archivo Histórico del Estado de Jalisco, Guadalajara, Jal.

AHMG Archivo Histórico Municipal de Guadalajara, Guadalajara, Jal.

AHSRE Archivo Histórico de la Secretaría de Relaciones Exteriores, México, D.F.

AHTSJ Archivo Histórico del Tribunal Superior de Justicia, México, D.F.

AIPEJ Archivo de Instrumentos Públicos del Estado de Jalisco, Guadalajara, Jal.

AMAEM Archivo del Ministerio de Asuntos Exteriores, Madrid

ANCM Archivo de Notarías de la Ciudad de México, México, D.F.

ANF Archives Nacionales, Paris

APFSM Archivo Privado de la Familia Solano Martino

BPEJ Biblioteca Pública del Estado de Jalisco, Guadalajara, Jal. 



\section{Autoras y autores}

Reinhard Liehr es profesor emérito de Historia de América Latina en la Freie Universität Berlin; e-mail: <liehr@zedat.fu-berlin.de>.

Lucía Martínez Moctezuma trabaja como profesora investigadora de Historia en la Universidad Autónoma del Estado de Morelos (México); e-mail:<luciamm@buzon.uaem.mx>.

Rosa María Meyer Cosío es investigadora de Historia en la Dirección de Estudios Históricos del Instituto Nacional de Antropología e Historia, México, D.F.; e-mail: <rosa.meyer@gmail.com>.

Carlos Riojas López trabaja como profesor investigador de Historia Económica en el Centro Universitario de Ciencias Económico-Administrativas (CUCEA) de la Universidad de Guadalajara (México); e-mail:<criojas@cucea.udg.mx>.

Alejandro Tortolero Villaseñor es profesor investigador de Historia en la Universidad Autónoma de México-Iztapalapa; e-mail: <atv@ xanum.uam.mx>. 



\section{BIBLIOTHECA IBERO-AMERICANA}

Vol. 100: Torsten Eßer, Patrick Frölicher (Hrsg.):

„Alles in meinem Dasein ist Musik..." Kubanische Musik von Rumba bis Techno. 2004; 638 S. ISBN 3-86527-164-2

Vol. 101: Klaas Dykmann:

Philanthropic Endeavors or the Exploitation of an Ideal?

The Human Rights Policy of the Organization of American States in Latin America. 2004; 506 p. ISBN 3-86527-165-0

Vol. 102: Nikolaus Böttcher, Isabel Galaor, Bernd Hausberger (eds.):

Los buenos, los malos y los feos. Poder y resistencia en América Latina. 2005; 512 p. ISBN 3-86527-200-2

Vol. 103: Barbara Potthast, Sandra Carreras (eds.):

Entre la familia, la sociedad y el Estado. Niños y jóvenes en América Latina (siglos XIX-XX). 2005; 404 p. ISBN 386527-218-5

Vol. 104: Stephan Hollensteiner:

Aufstieg und Randlage. Linksintellektuelle, demokratischer

Wandel und Politik in Argentinien und Brasilien. 2005; 462

S. ISBN 3-86527-239-8

Vol. 105: Marianne Braig, Ottmar Ette, Dieter Ingenschay, Günther Maihold (Hrsg.):

Grenzen der Macht-Macht der Grenzen. Lateinamerika im globalen Kontext. 2005; 240 S. ISBN 3-86527-246-0

Vol. 106: Marcela García Sebastiani (ed.):

Fascismo y antifascismo. Peronismo $y$ antiperonismo. Conflictos políticos e ideológicos en la Argentina (19301955). 2006; en preparación

Vol. 107: Guiomar Ciapuscio, Konstanze Jungbluth, Dorothee Kaiser, Célia Lopes (eds.):

Sincronía y diacronía de tradiciones discursivas en Latinoamérica. 2006; en preparación 

Vol. 108: Reinhard Liehr (ed.):

Empresas y modernización en México desde las reformas borbónicas hasta el Porfiriato. 2006; 190 p. ISBN 3-86527$270-3$

\section{Vervuert Verlagsgesellschaft}

Wielandstr. 40

D-60318 Frankfurt am Main

Tel.: (+49) 695974617

Fax: (+49) 695978743

info@iberoamericanalibros.com

www.ibero-americana.net

\section{IBEROAMERICANA}

C/ Amor de Dios, 1

E - 28014 Madrid

Tel.: (+34) 91-4293522

Fax: (+34) 91-4295397

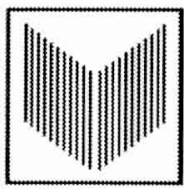




El volumen reúne cuatro estudios sobre empresas familiares en México y sus intentos de modernización socio-económica en el período que va de las reformas borbónicas a la dictadura de Porfirio Díaz. El primero analiza el control del abastecimiento de maíz en la Ciudad de México, derivado del transporte fluvial, por parte de los grandes empresarios agrarios de la provincia de Chalco, al oriente de la capital, durante la segunda mitad del siglo XVIII. El segundo examina las empresas comerciales, mineras y financieras de un inmigrante británico en el pais y sus excelentes relaciones con políticos influventes, mientras que el tercero describe la industria textil del estado de Jalisco durante el siglo XIX, centrándose en la figura del fabricante-mercader, que suministraba materias primas o dinero en efectivo a artesanos dependientes, como tipo de empresario innovador de la llamada protoindustrialización. Finalmente, el cuarto estudio examina las empresas mercantiles, tabacaleras y textiles de un inmigrante español, que a finales del Porfiriato invirtió en latifundios del municipio de Chalco y de los estados de Tamaulipas y Chihuahua organizándolos como sociedades anónimas con tecnología moderna. 